دور صفحات مقاومة الشائعات على مواقع التواصل

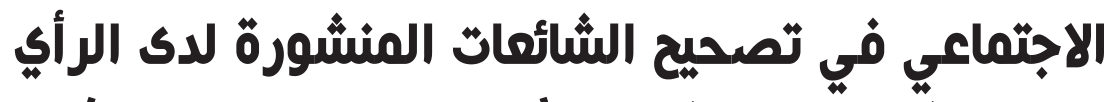
العام في ضُوء مفهوم احروب الجيل الخامس).. دراسة تحليلية وميدانية د. داللا أحمد محمد عبد الوهاب منصور المدرس بقسم علوم الاتصال والإعلام، كلية الآداب،

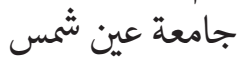

مقدُمَمْ:

تزايد اهتمام الباحثين في مجال الكَّأي العام والاتصال السياسي

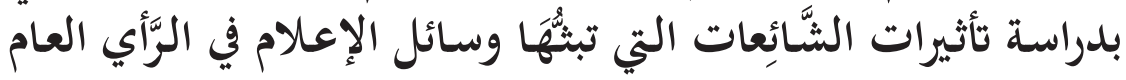

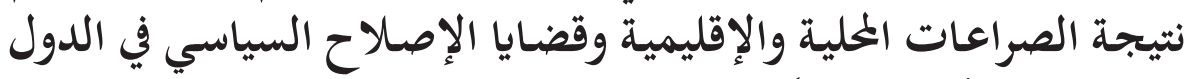

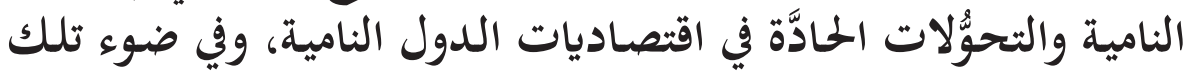

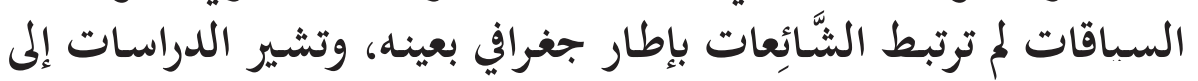

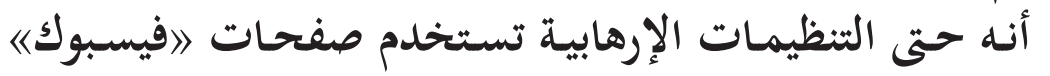

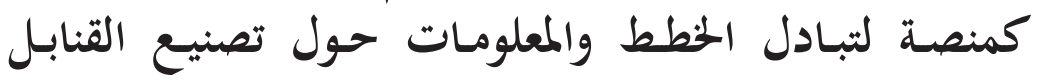

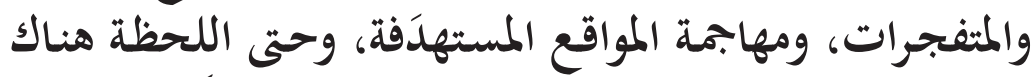

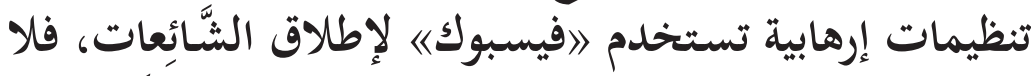

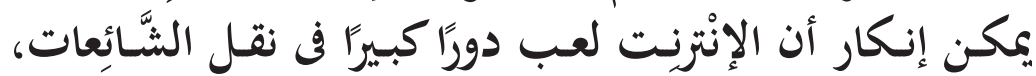

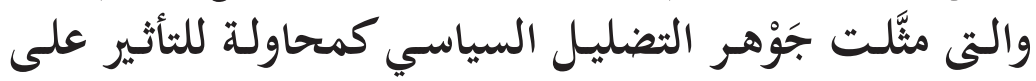

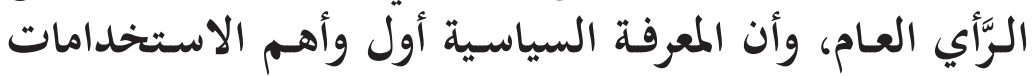
السياسية الافتراضية التي تُسهم في تشكيل الوعي السياسي الهئ. 


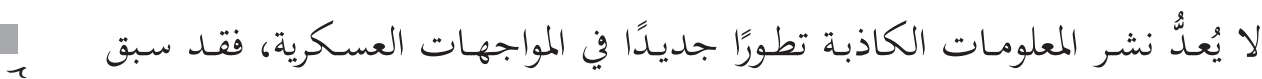

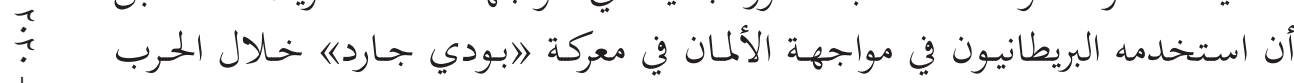

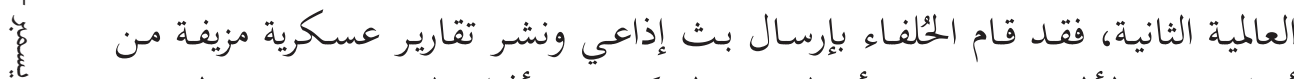

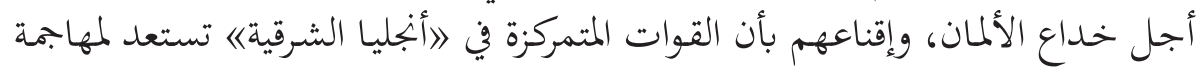

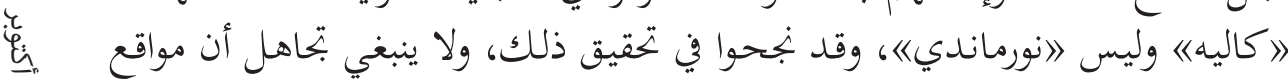

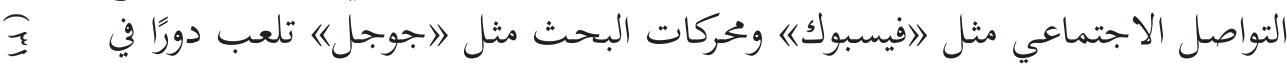

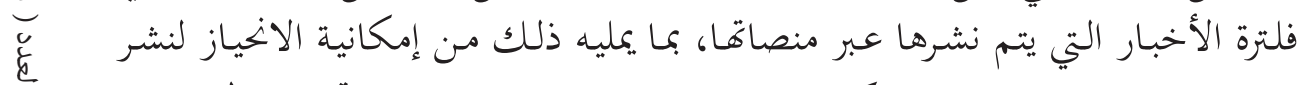

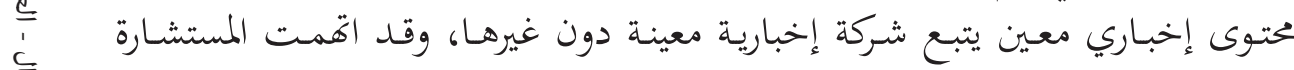

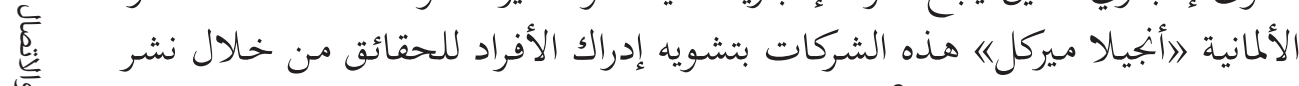
معلومات معينة دون أخرى (2).

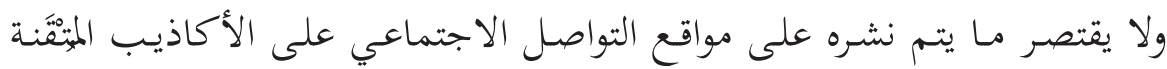

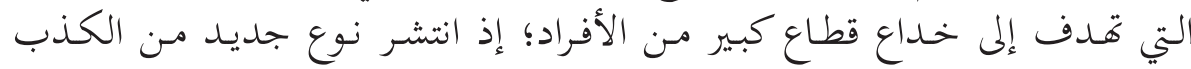

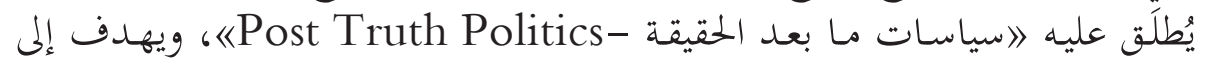

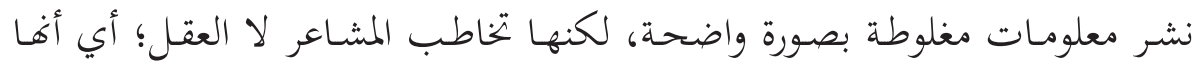

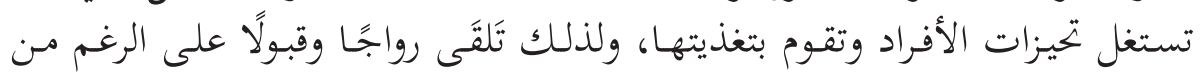

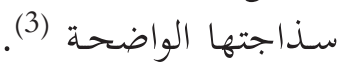

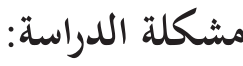

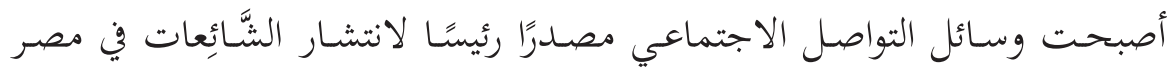

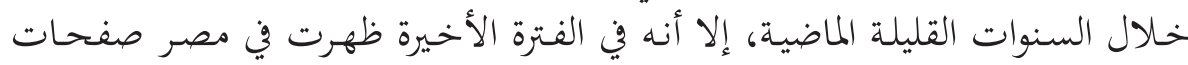

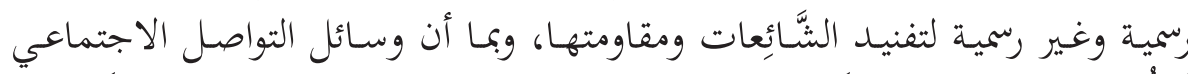

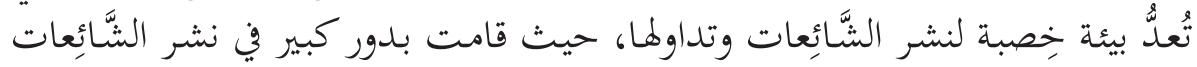

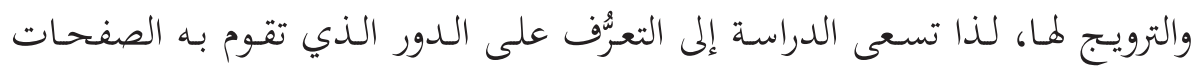

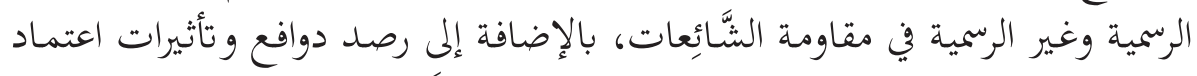
الجمههور المصري على تلك الصفحات في مقاومة الشَّائعة.

\section{أهداف الدراسة:}

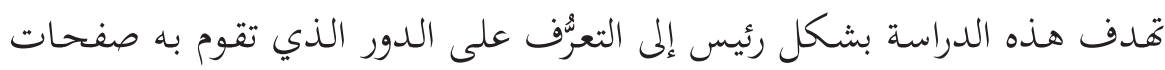

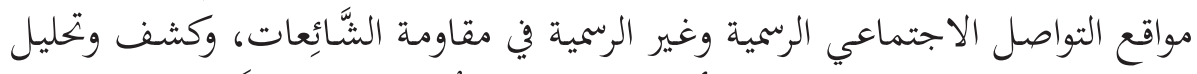

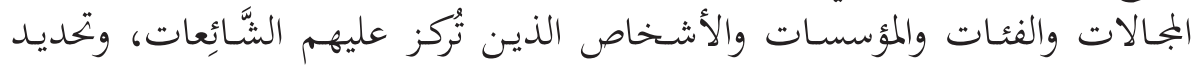


أهـداف الشـائعة، وتتمثل أهـداف الدراسـة في:

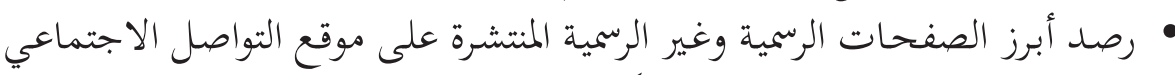

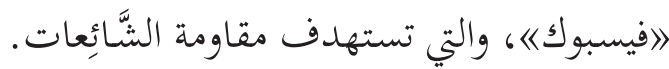

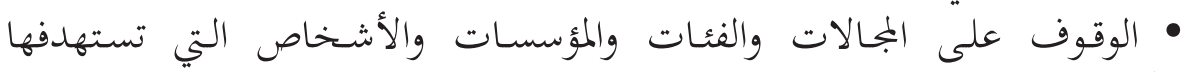

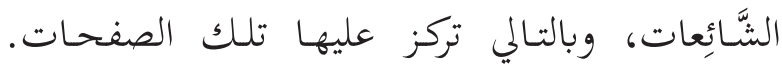

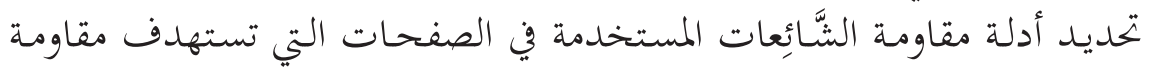
الشَّائِعات.

رصد حجم اعتماد المبحوثين على تلك الصفحات.

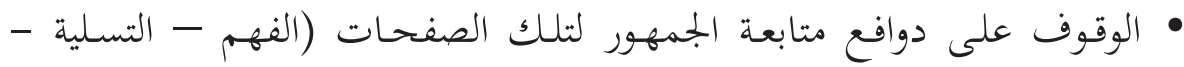

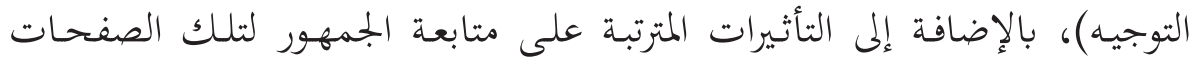

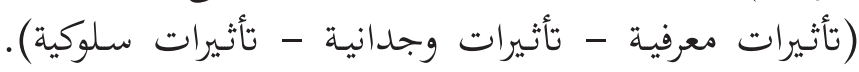

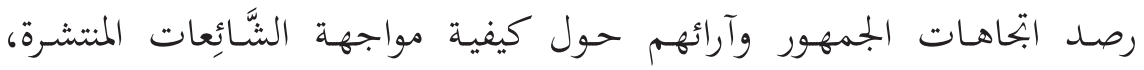

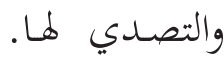

\section{أهمية الدراسة:}

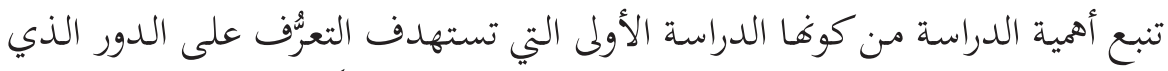

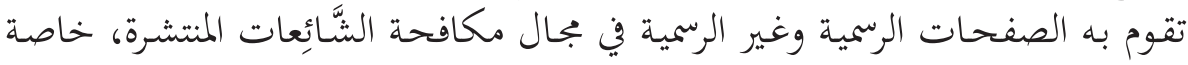

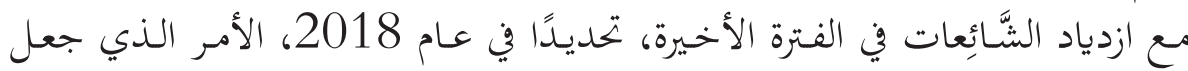

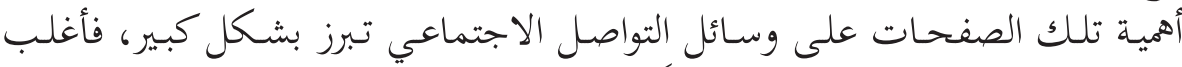

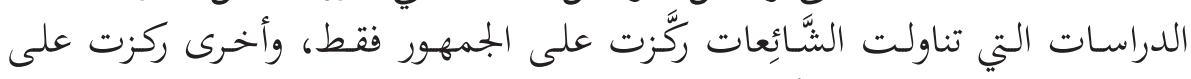

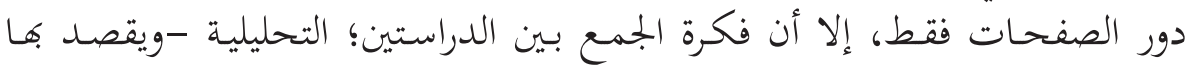

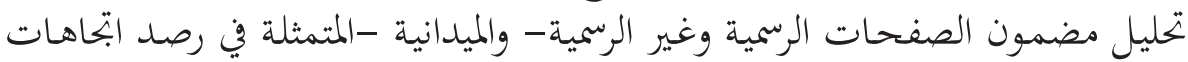
الجمهور نحو الصفحات- لم تقم بها الدراسـات الإعلامية.

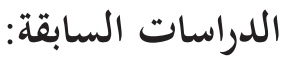

قامت الباحثة برصد الدراسات والأوراق البحثية ذات الصلة بموضوع الدراسة، وقد الدابد تم تصنيف الدراسات السابقة إلى:

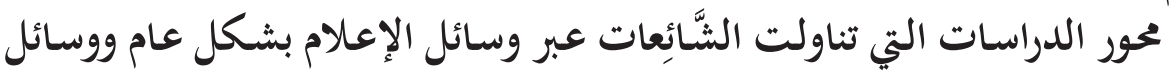
التواصل الاجتماعي بشكل خاص.

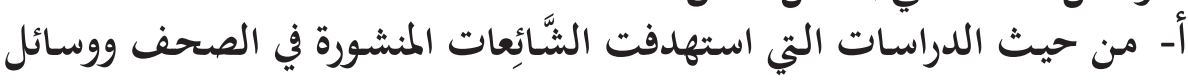


الإعلام بشكل عام وتأثيرهـا على الرَّأي العام:

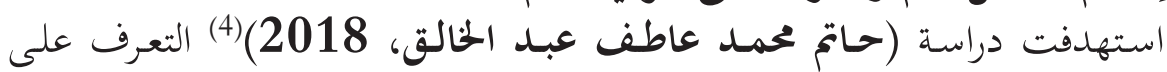

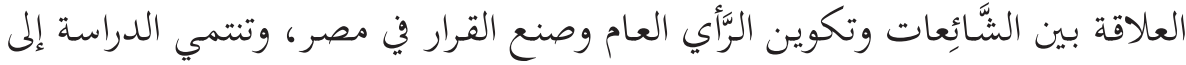

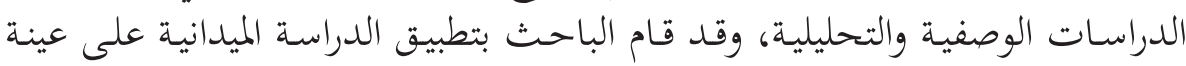

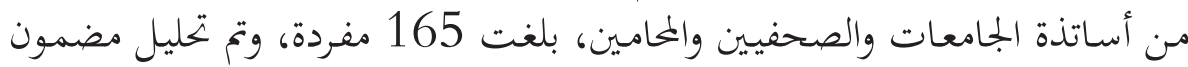

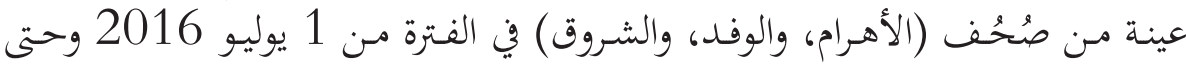

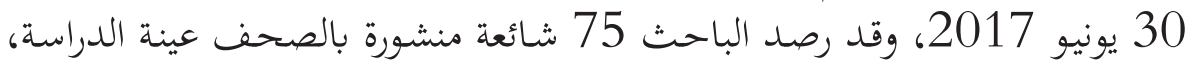

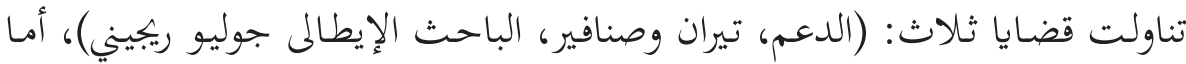

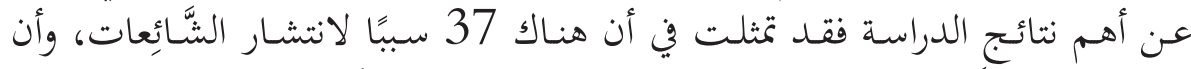

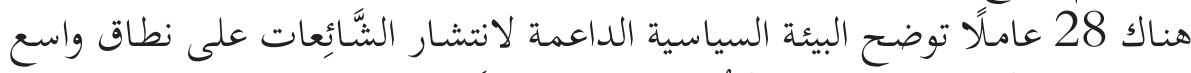

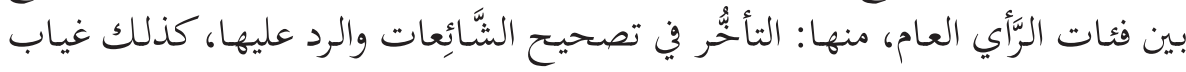
المعلومات وعدم وضوحها.

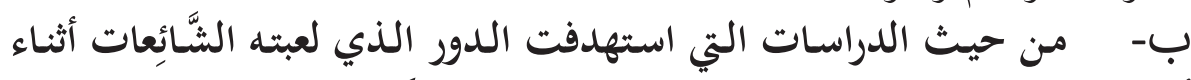

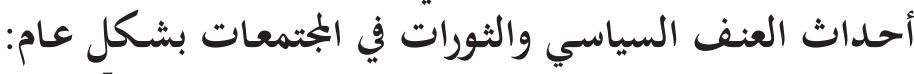

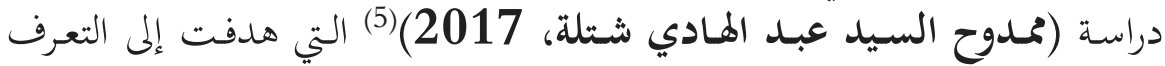

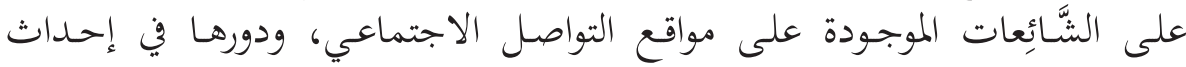

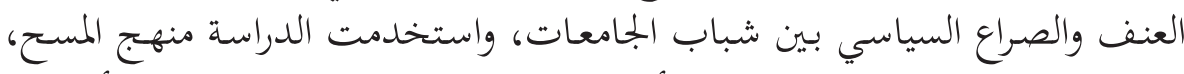

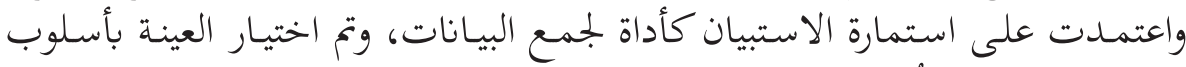

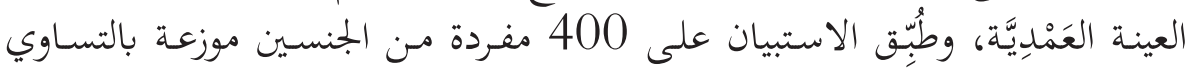

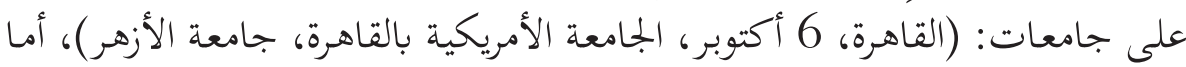

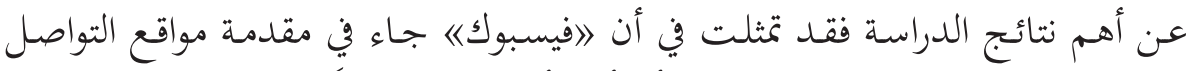

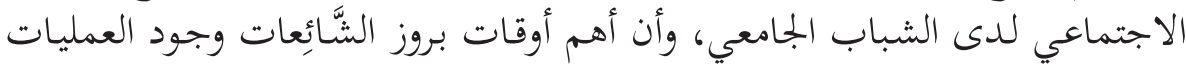

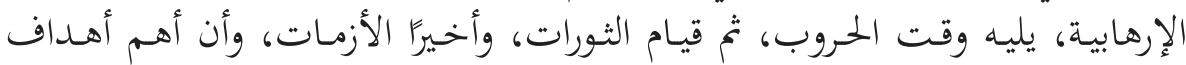

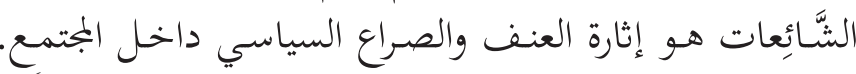

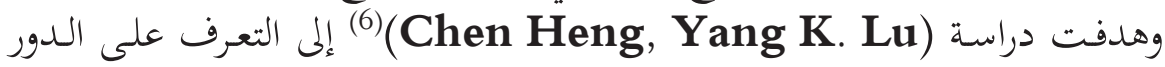

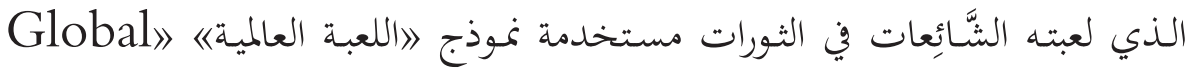
بوame Model

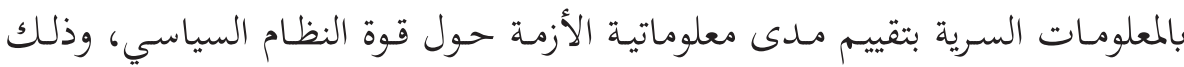

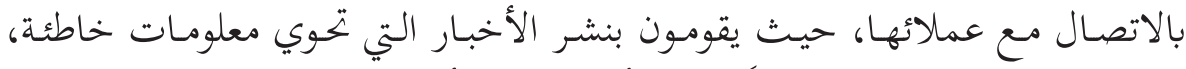

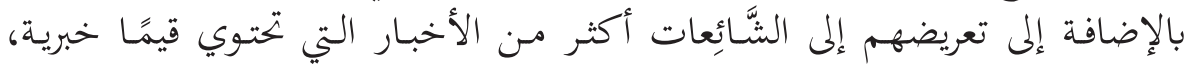




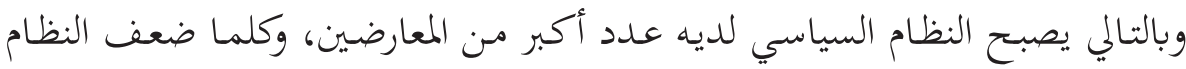

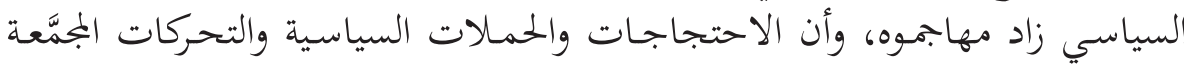

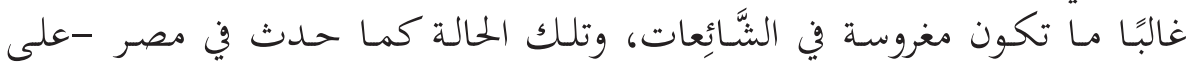

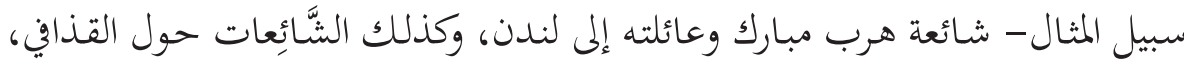

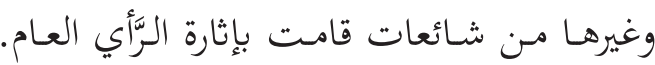

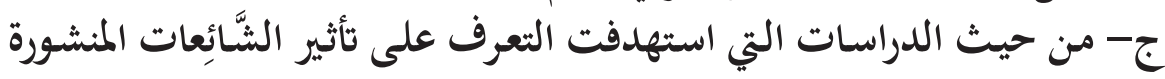

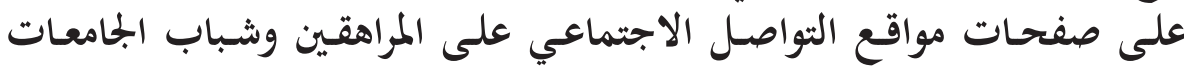

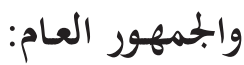

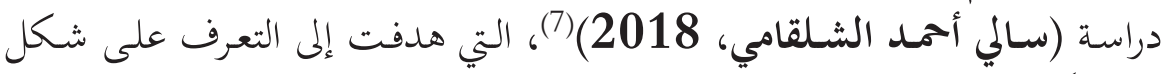

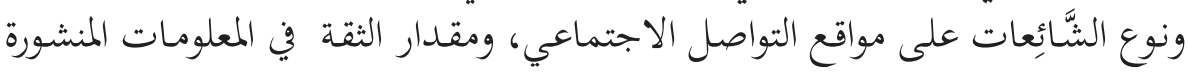

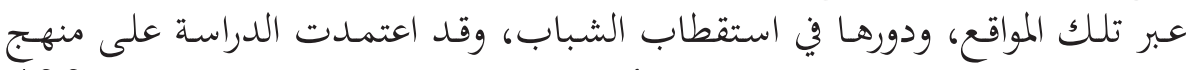

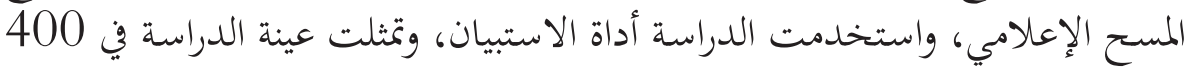

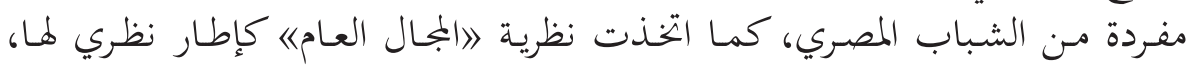

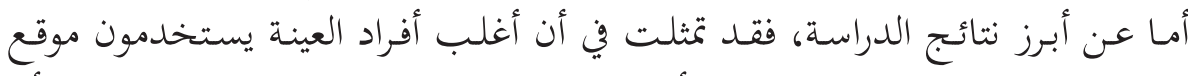

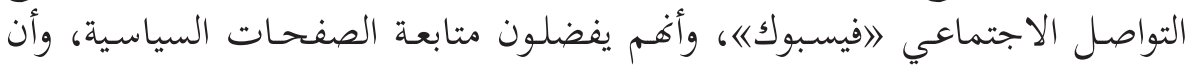

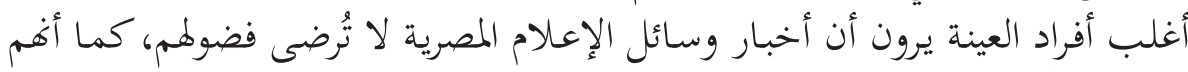

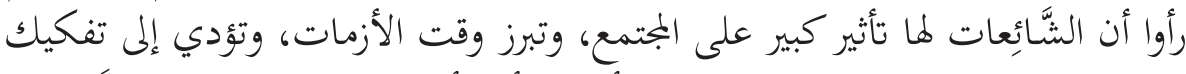

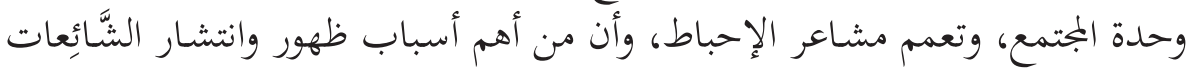

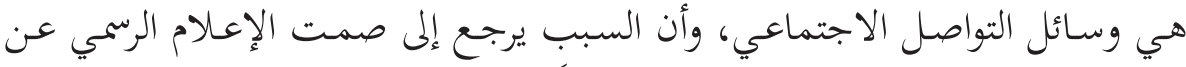

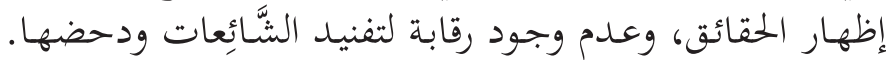

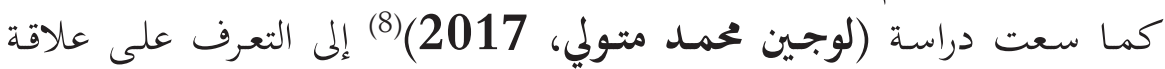

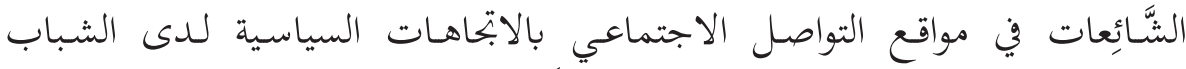

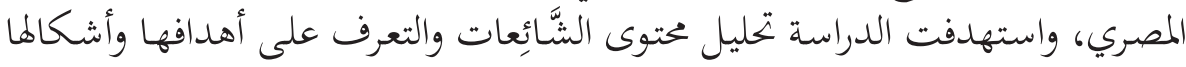

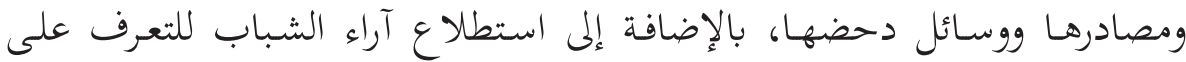

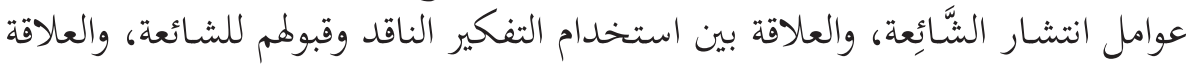

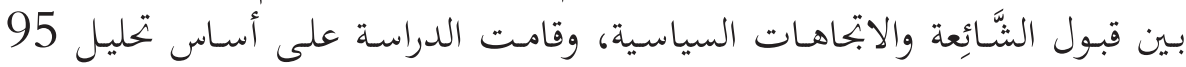

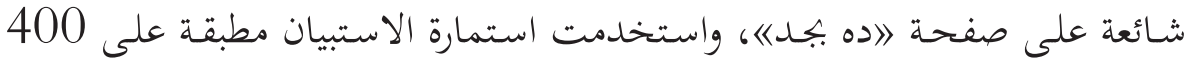

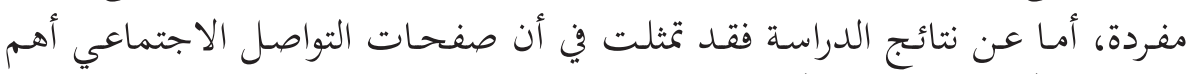

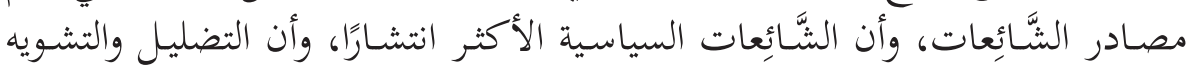

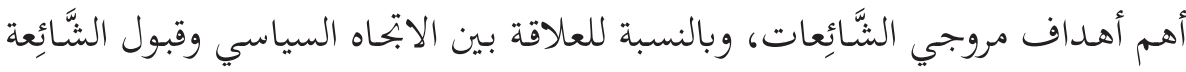




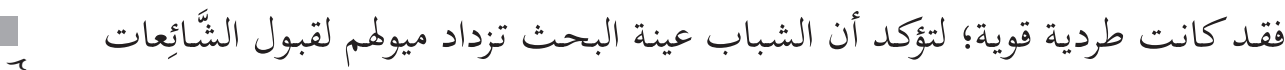

التي تتوافق مع معتقداتهم وانتماءاتهم وميولهم السياسية.

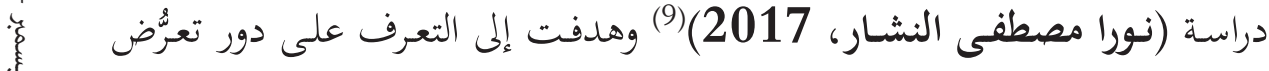

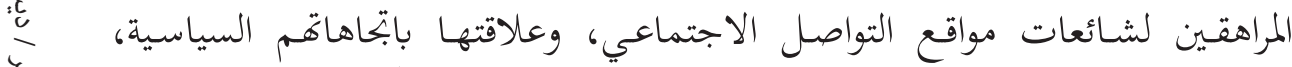

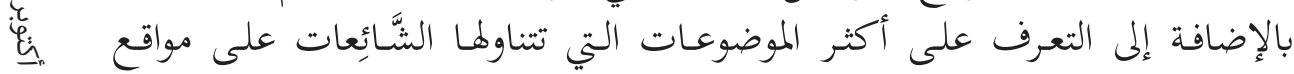

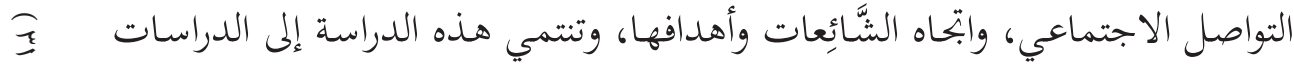

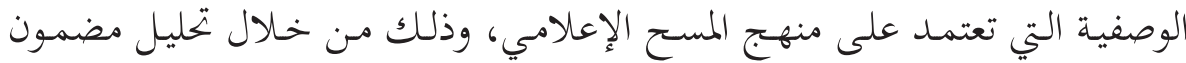

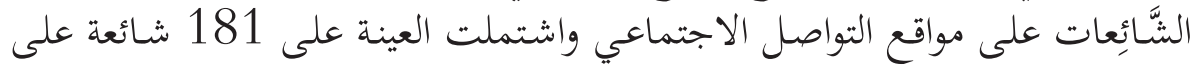

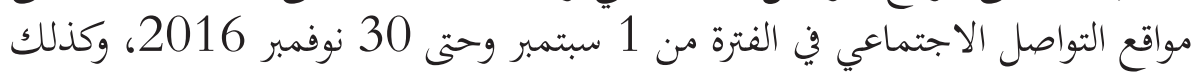

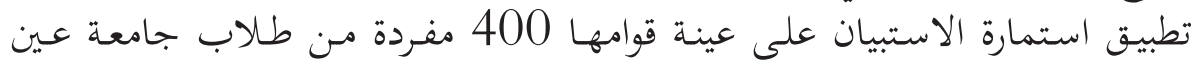

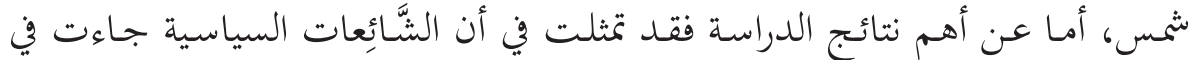

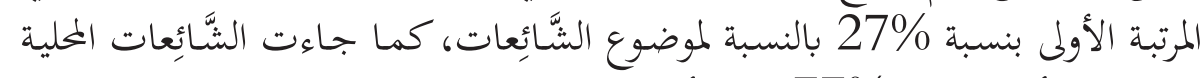

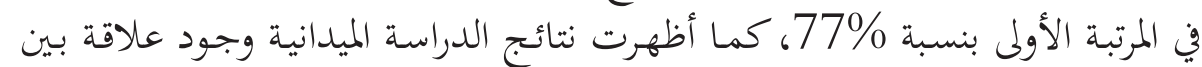
كثافة تعرض المراهقين لمواقع التواصل الاجتماعي واتبحاهاهـم السياسية.

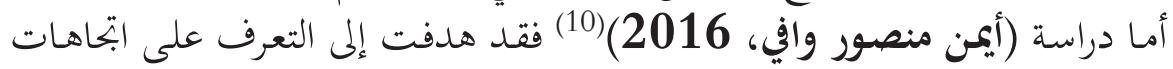

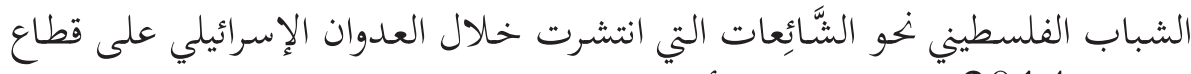

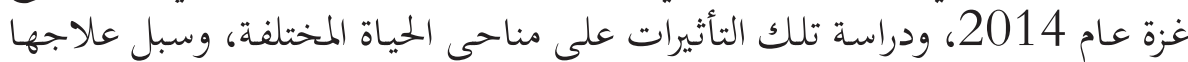

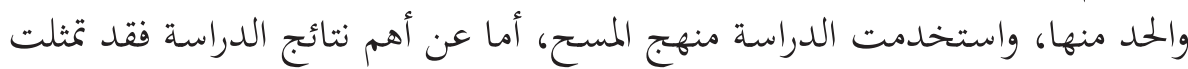

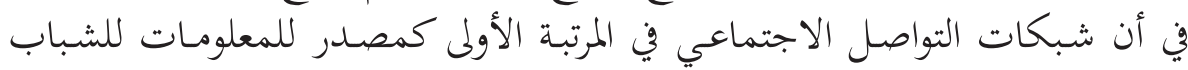

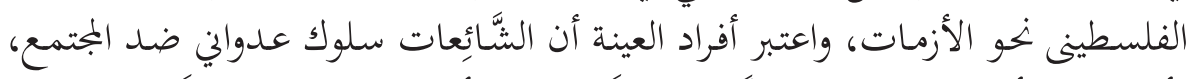

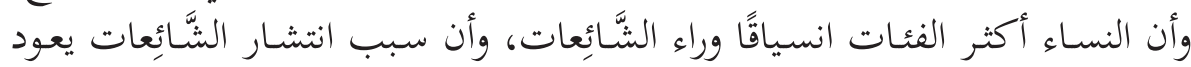

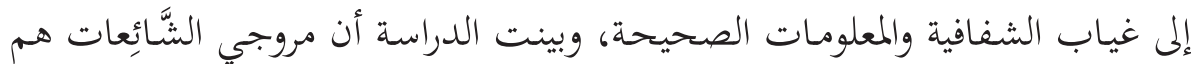

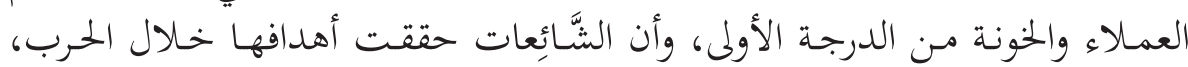
ومنها إحداث البلبة في الحياة.

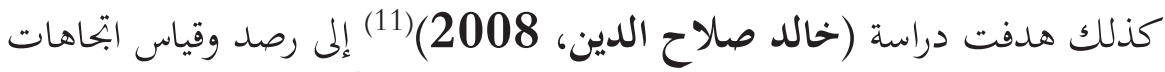

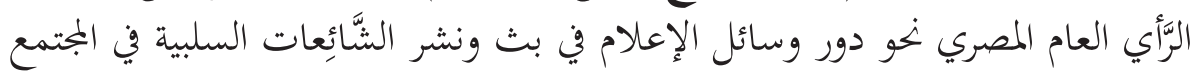

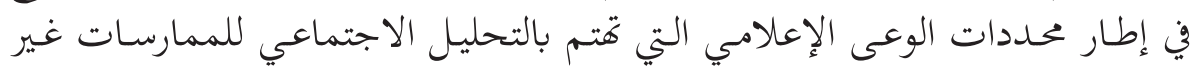

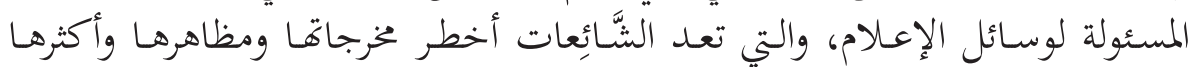

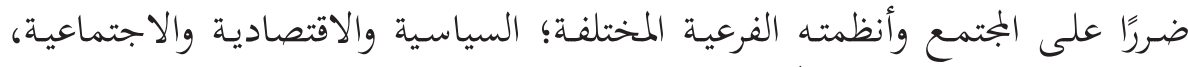

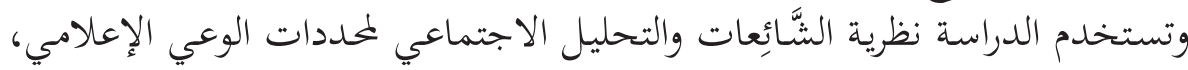


وتندرج الدراسة الحالية ضمن البحوث الوصفية والكمية التي ثتم برصد الواقع، أمسا

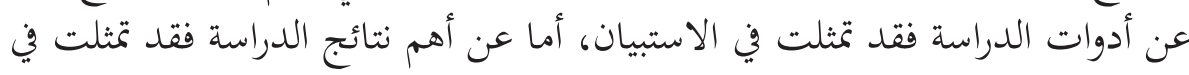

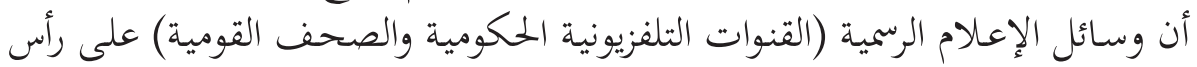

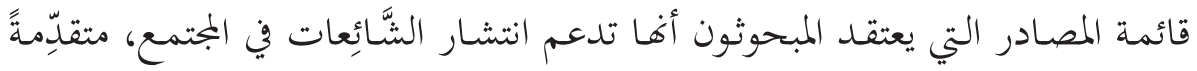

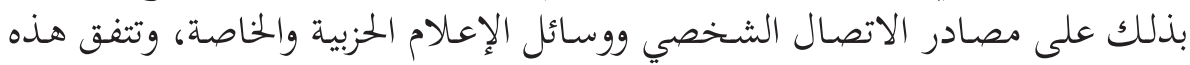

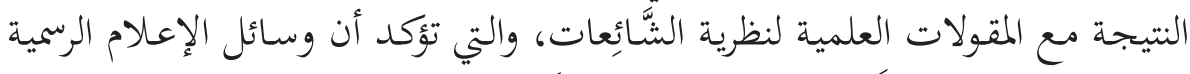

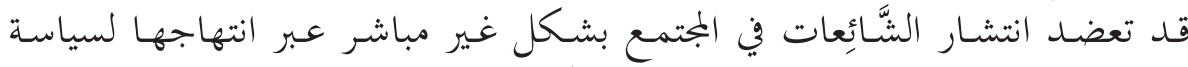

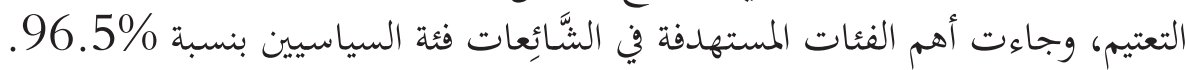

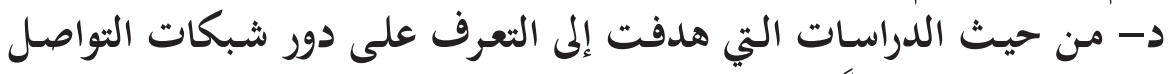

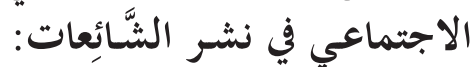

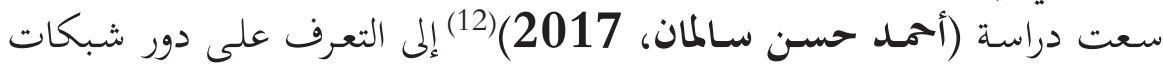

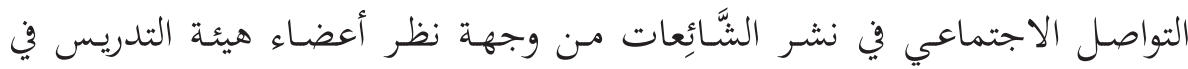

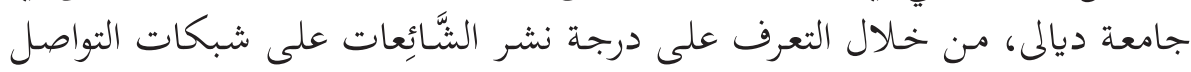

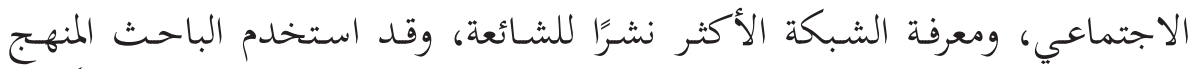

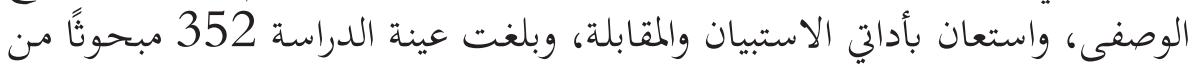

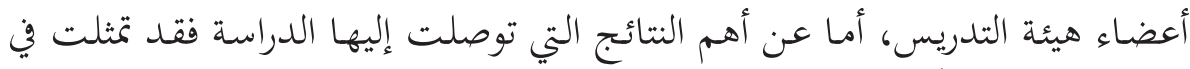

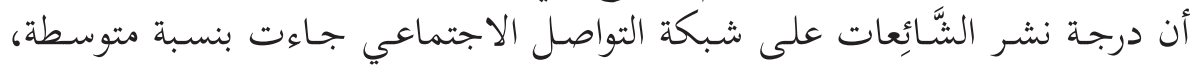

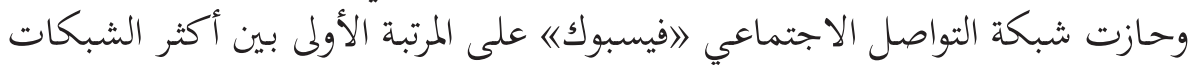

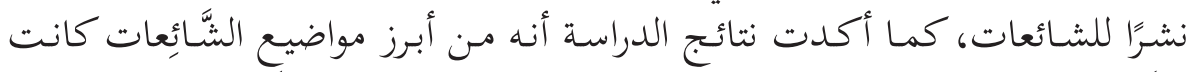

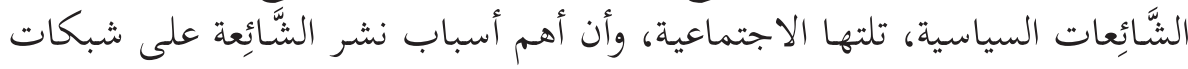

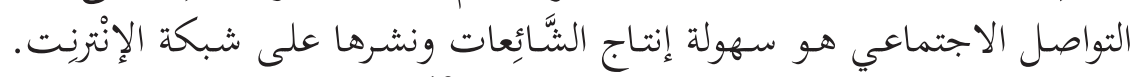

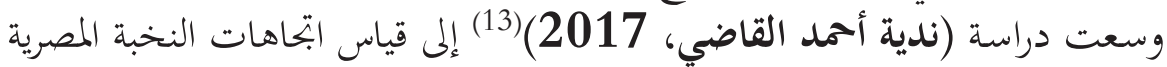

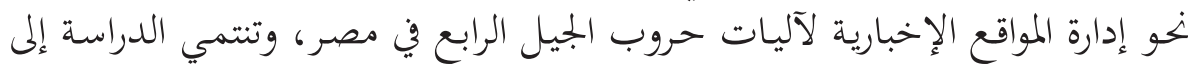

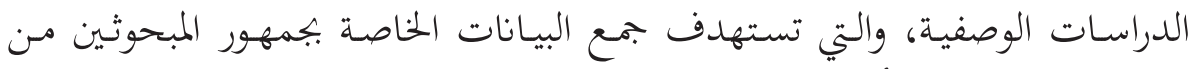

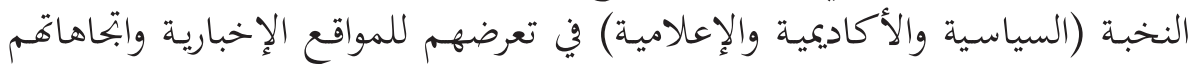

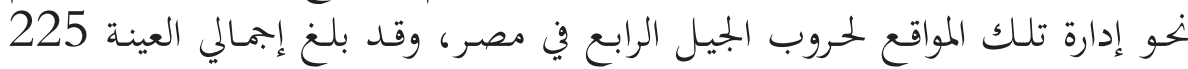

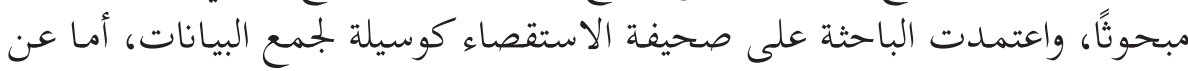

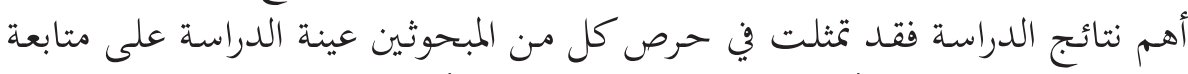

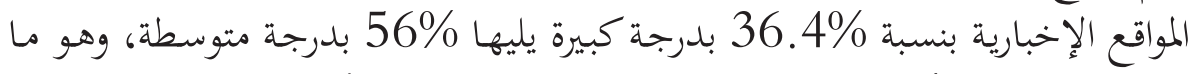

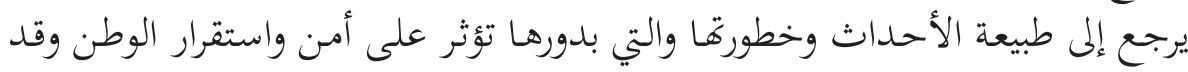




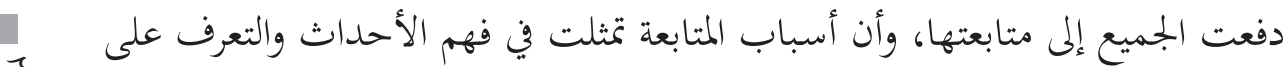

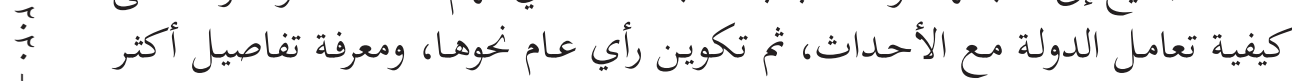

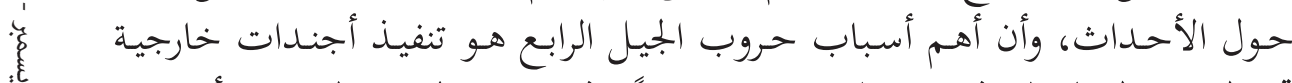

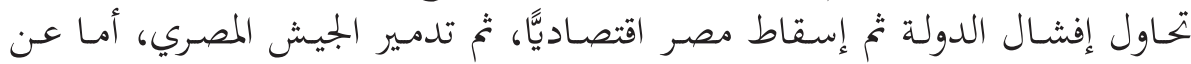

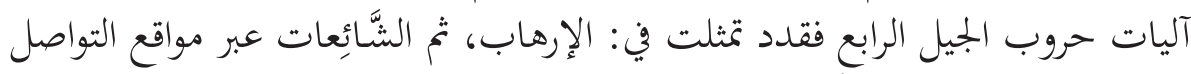

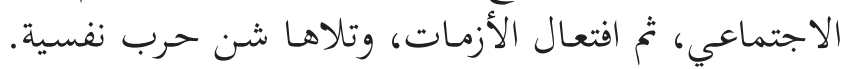

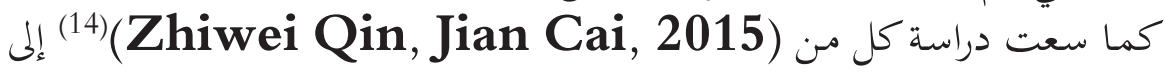

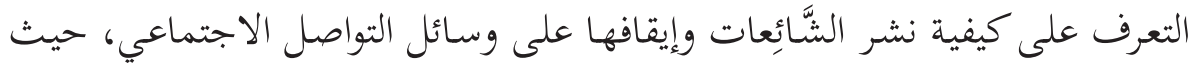

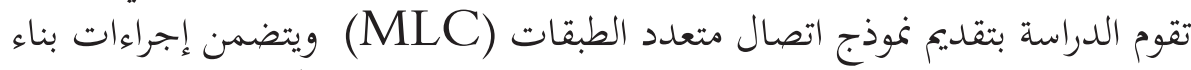

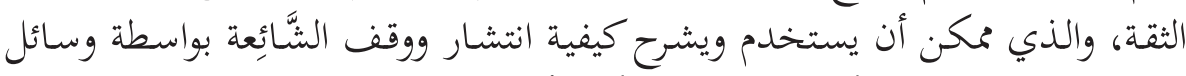

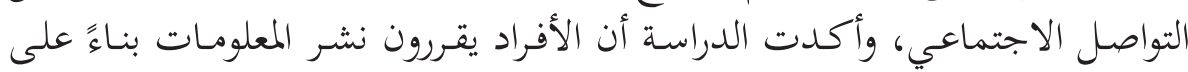

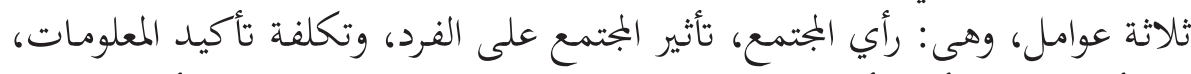

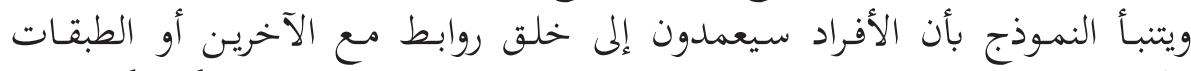

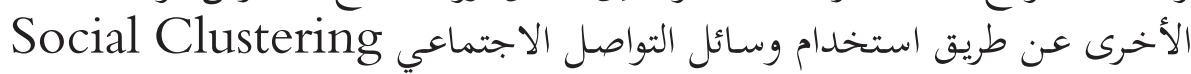

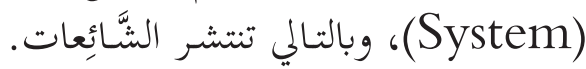

وأيضا سعت دراسة (Fang Lui, Andrew Burton Jone)

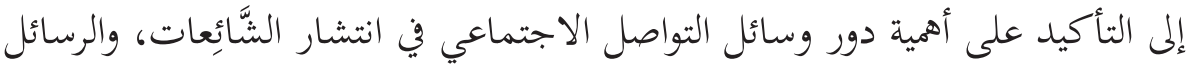

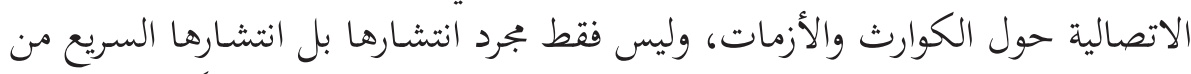

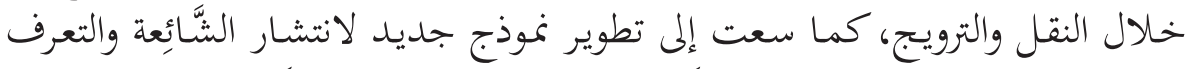

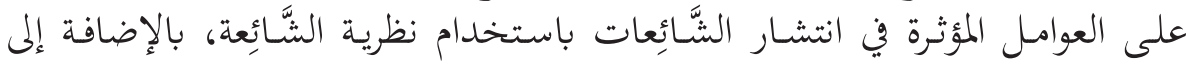

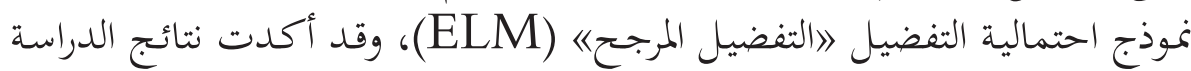

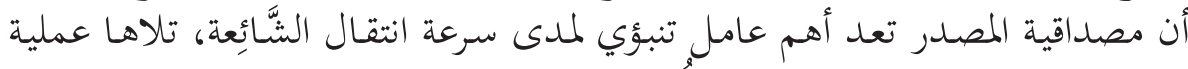

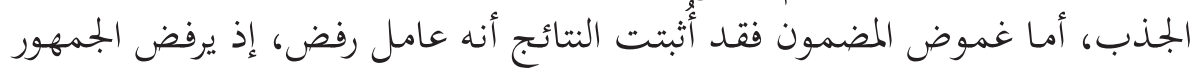

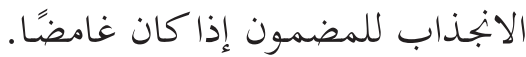

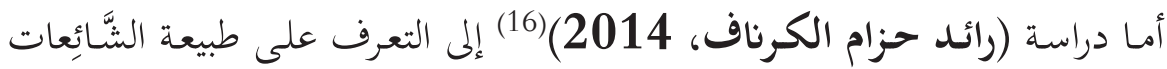

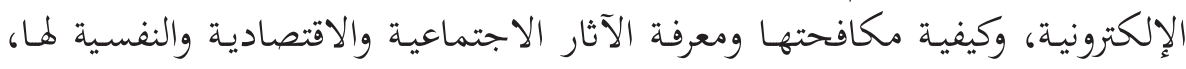

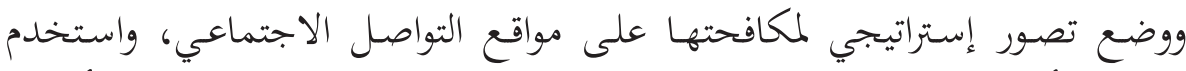

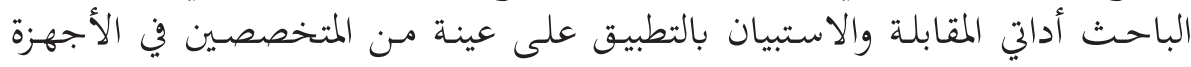

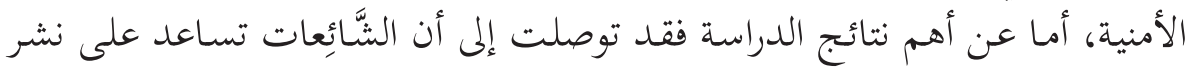

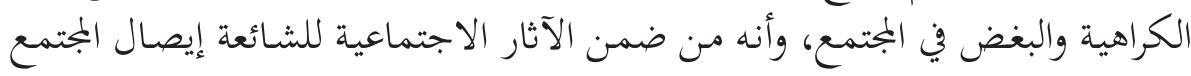




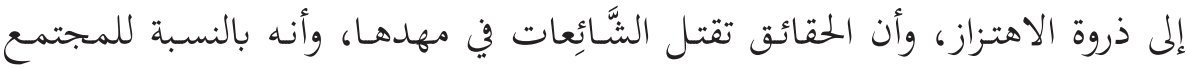

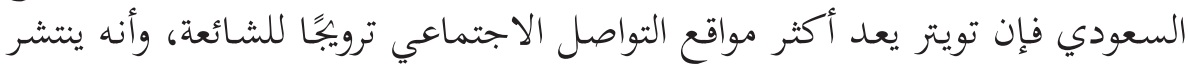

$$
\text { على تويتر أكثر من غيره. }
$$

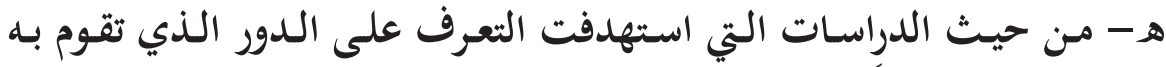

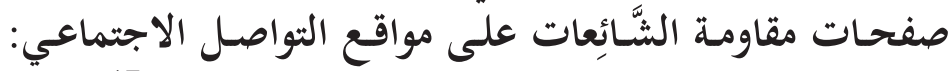

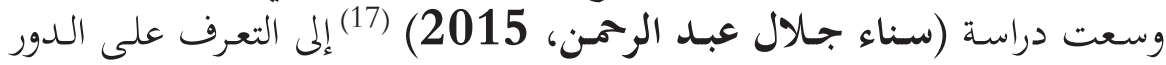

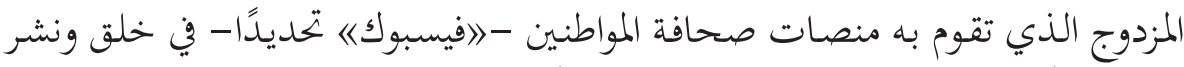

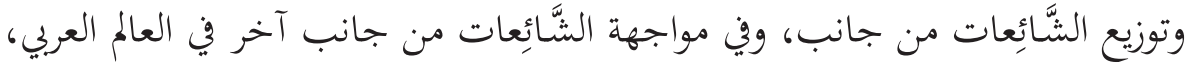

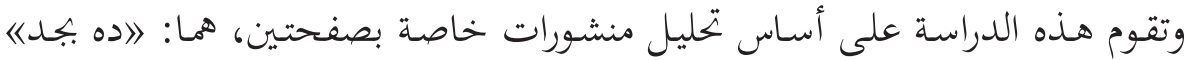

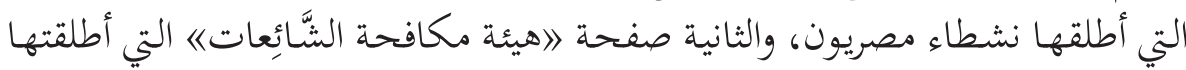

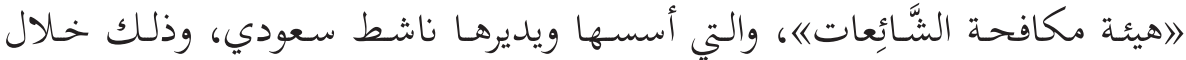

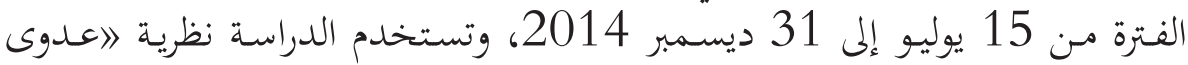

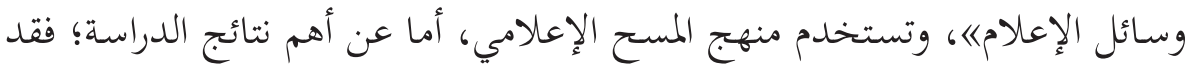

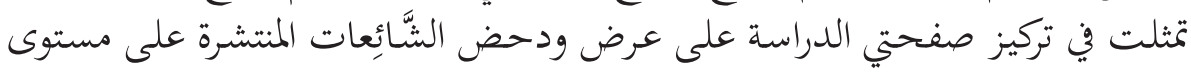

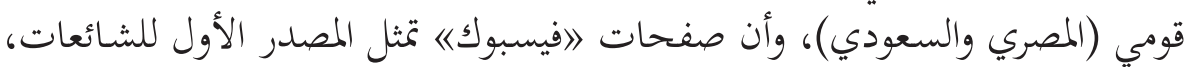

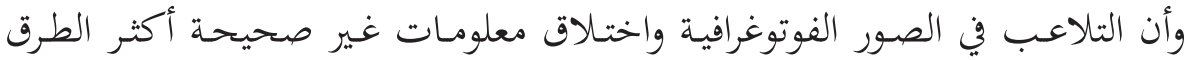

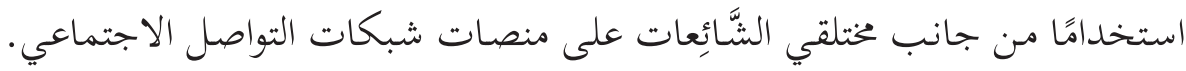

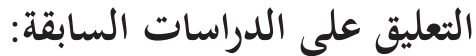

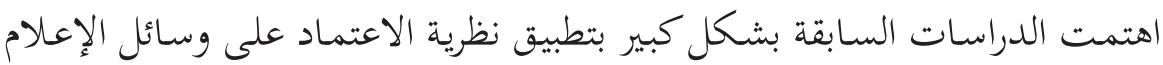

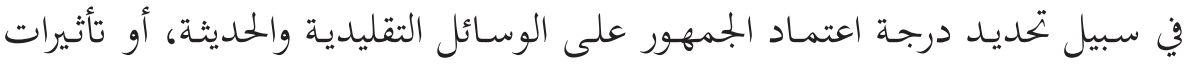

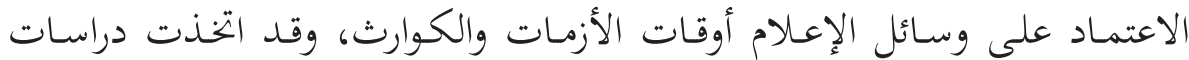

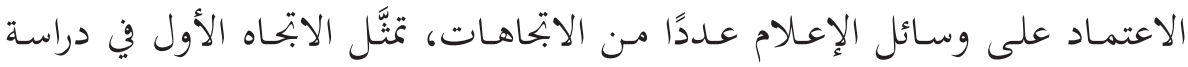

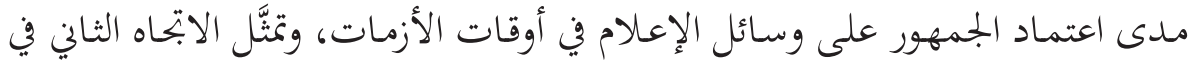

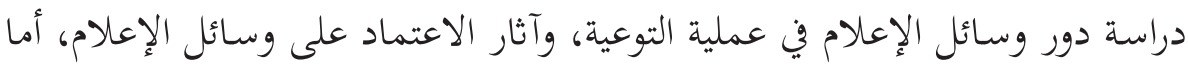

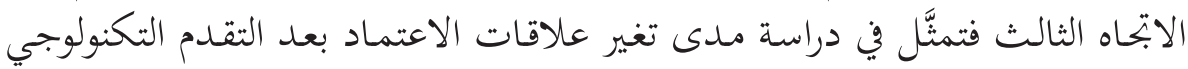

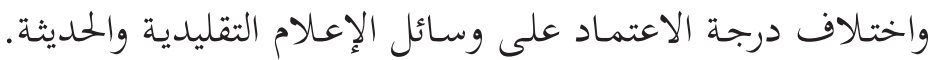
أفادت الدراسات السابقة الباحثة في: الإني

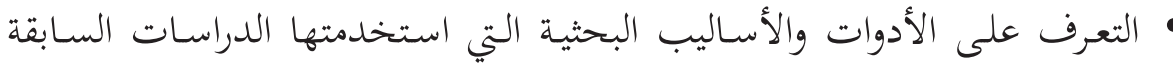

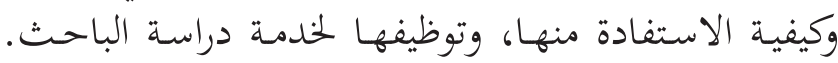


• • معرفة التطبيق العملي الميداني لنظرية الاعتماد.

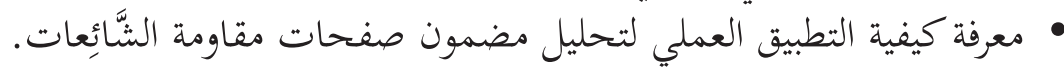

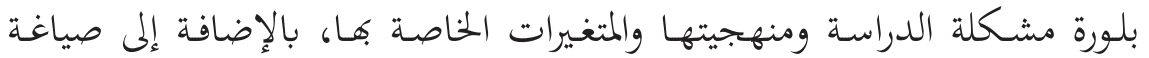
الإطار المنهجي والنظري والمعرين للدراسة.

\section{الإطار النظري للدراسة:}

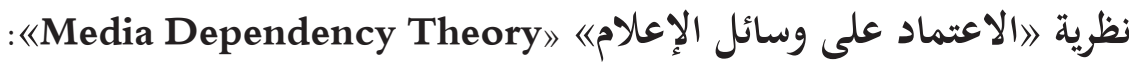

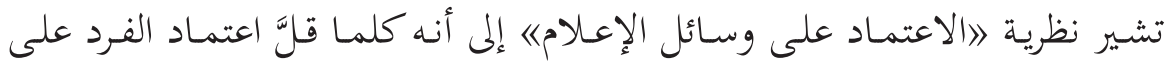

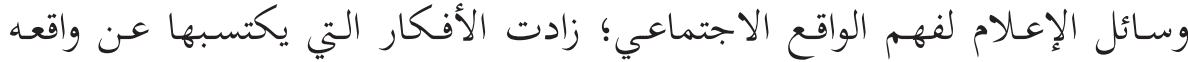

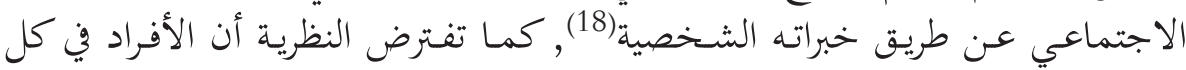

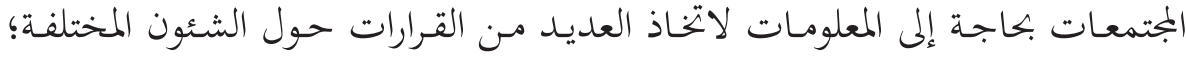

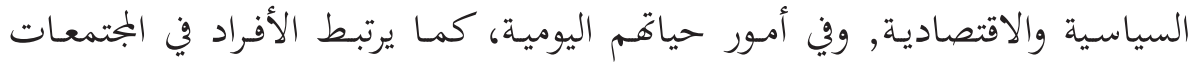

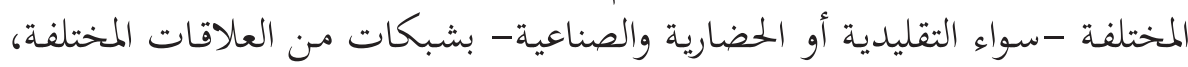

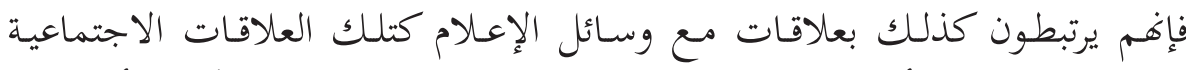

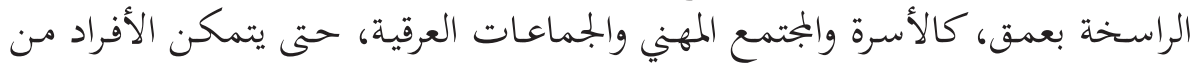

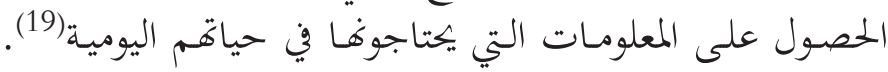

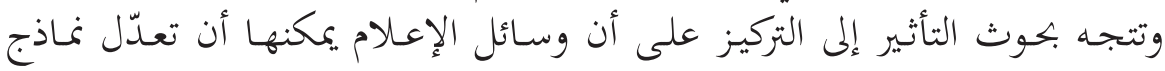

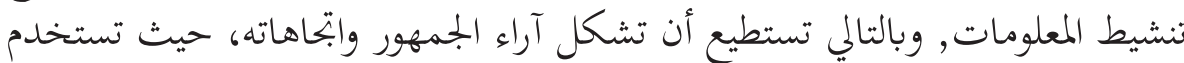

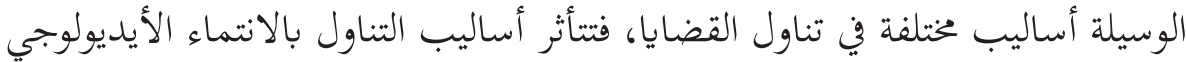

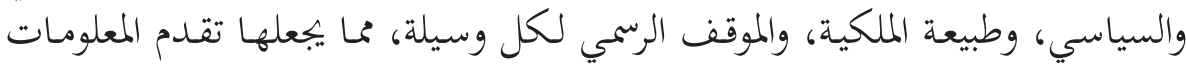

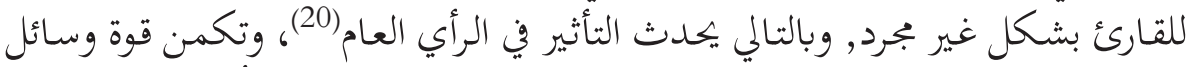

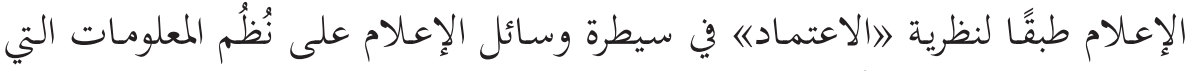

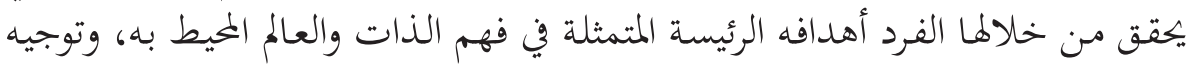

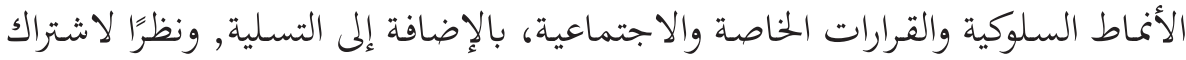

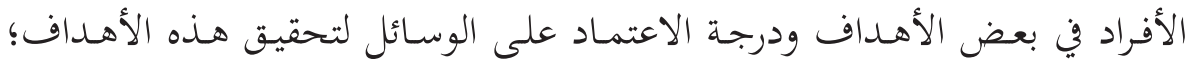

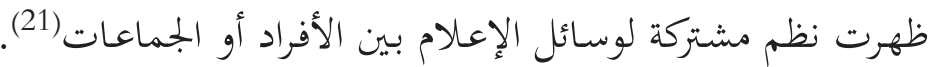

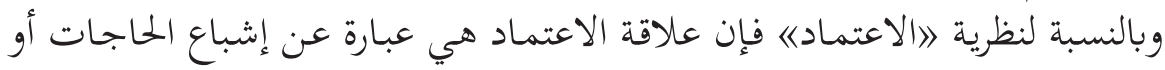

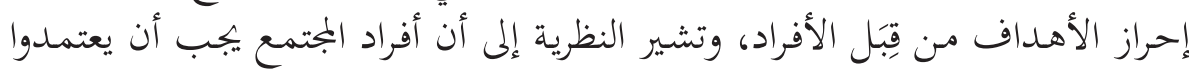

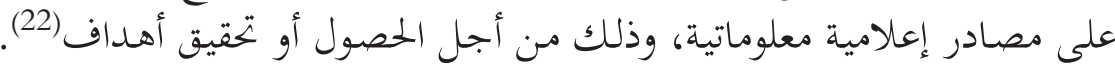

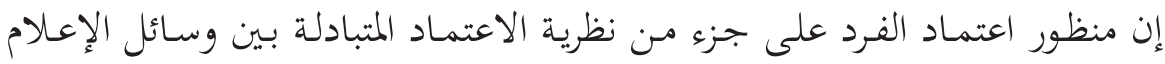


والنظم الاجتماعية والجمهور الذي يتعامل مع هذه الوسائل يهتم برصد التأثيرات

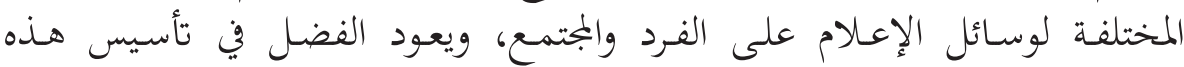

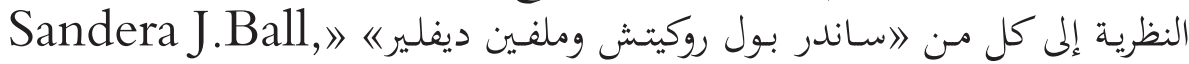

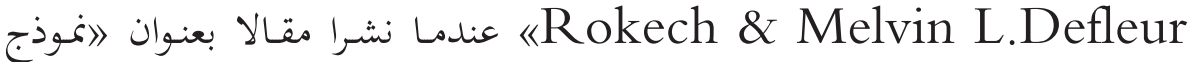
الاعتماد لدراسة تأثيرات وسائل الإعلام - dependency model of mass CCOmmunication

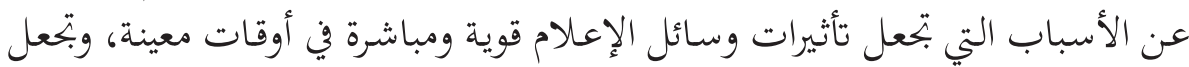

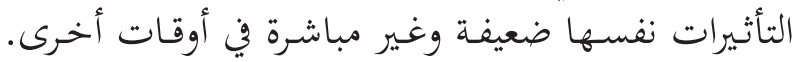

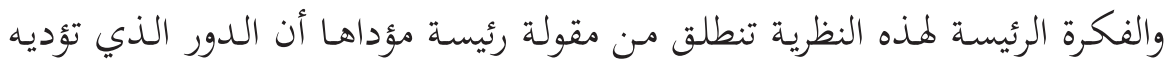

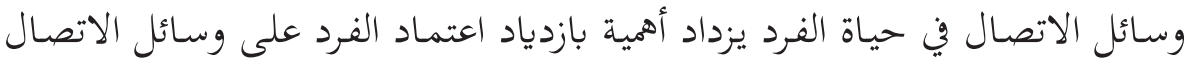

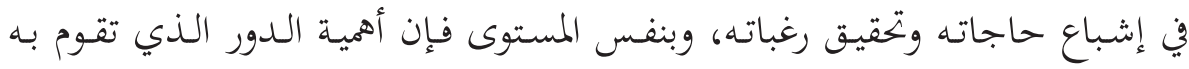

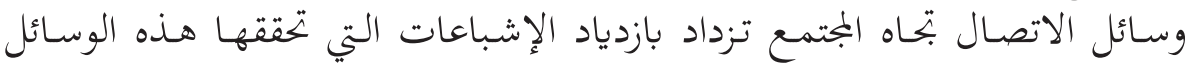

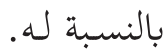

\section{وتقوم علاقات الاعتماد على وسائل الإعلام على ركيزتين أساسيتين، هما:}

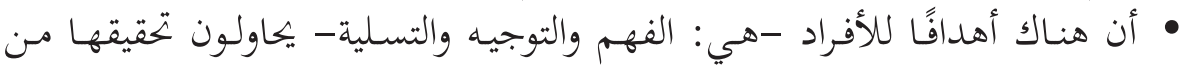

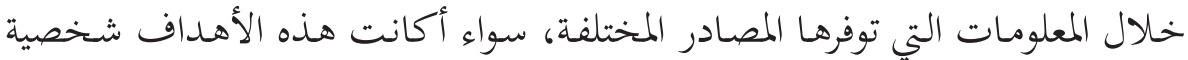

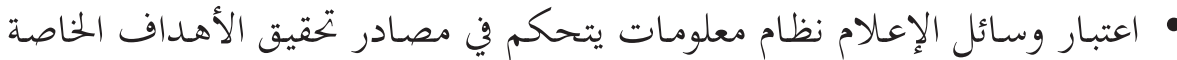

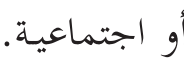

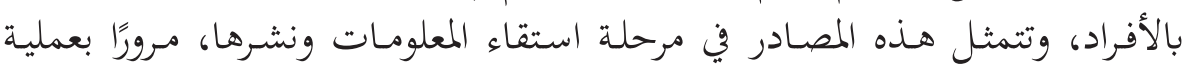

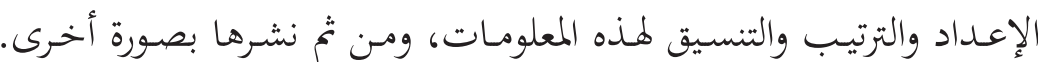

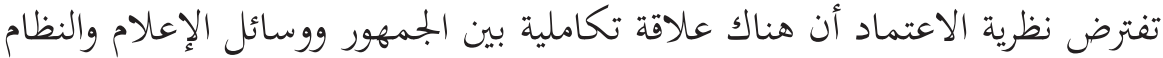

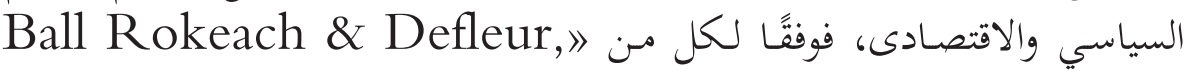

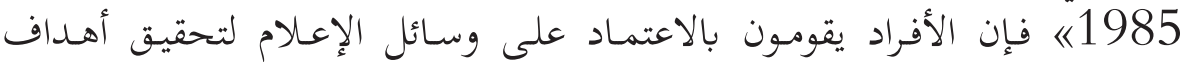

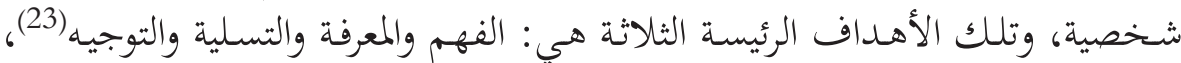

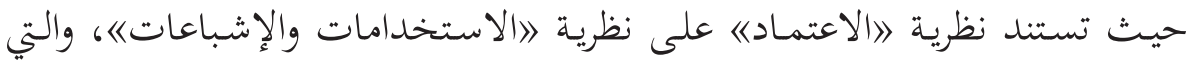
ترتبط أيضًا بنظرية ابنـاء الأجندة)《(24).

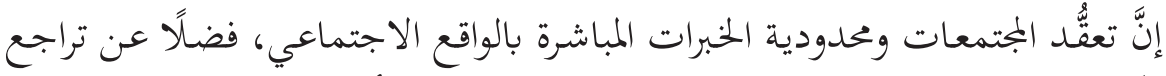

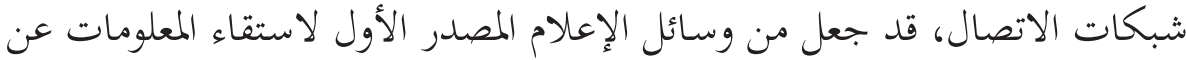
الأحداث والقضايا التي يفرزها الواقع الاجتماعي (25). 


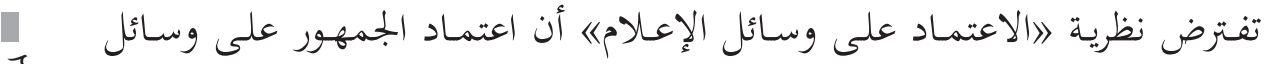

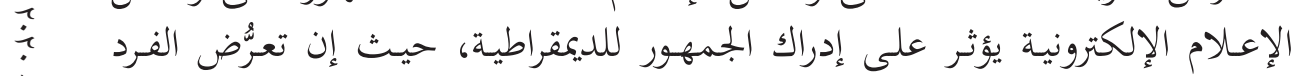

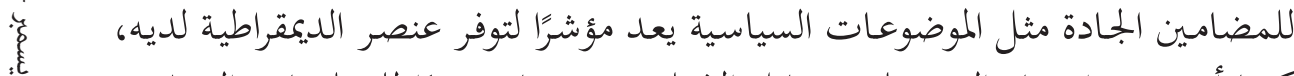

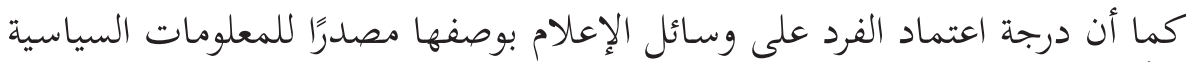

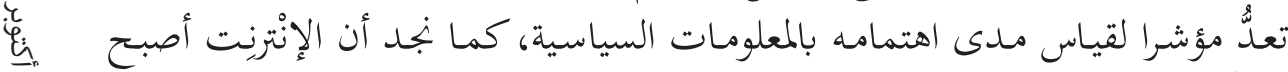

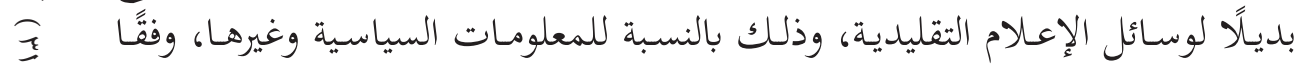

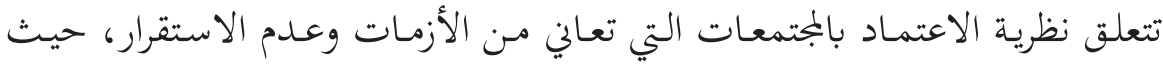

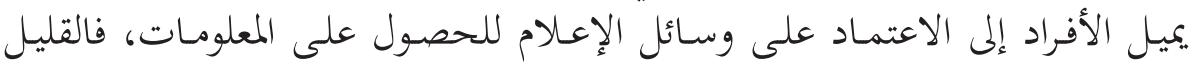

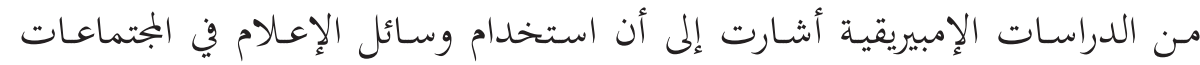

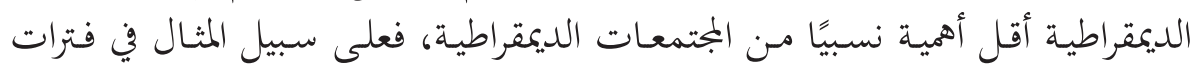

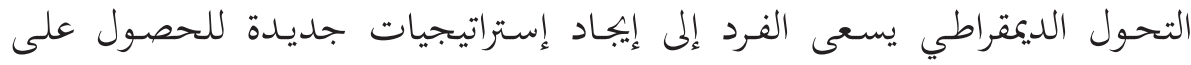

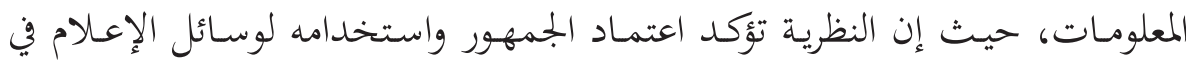

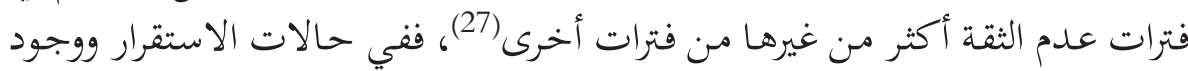

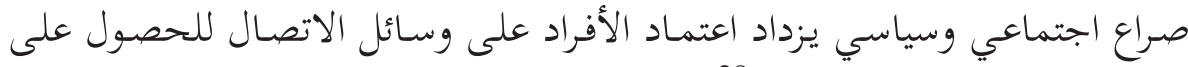

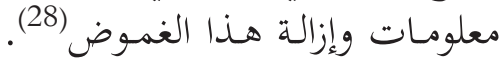

\section{علاقة نظرية الاعتماد بوسائل التواصل الاجتماعي ونشر الشَّائِعات:}

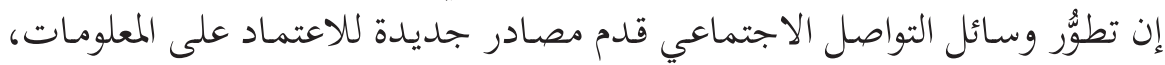

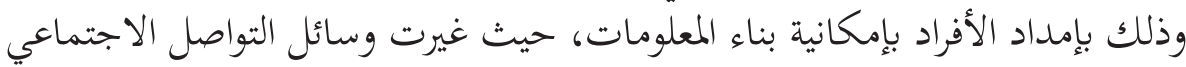

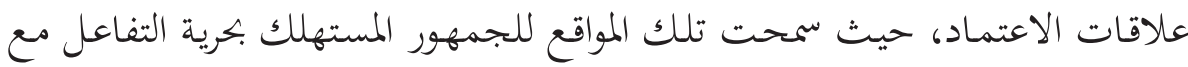

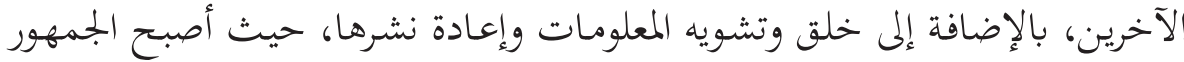

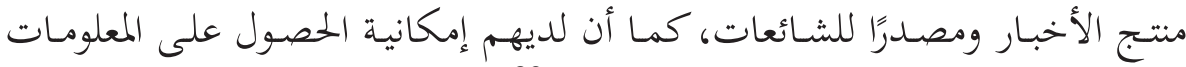

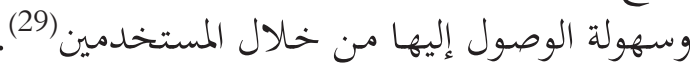

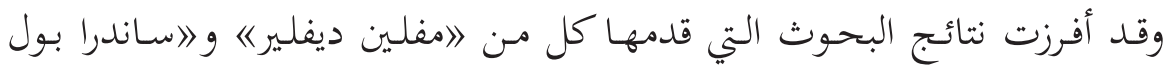

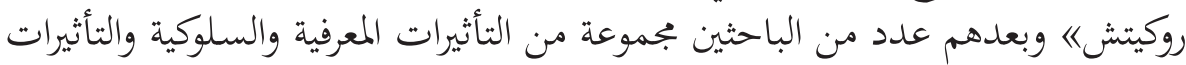
الوجدانية تتمثل في (30): 
• التأثيرات المعرفيـة: وتشـمل إحسـاس الأفراد بالغمـوض، وتشكل الاتجاه وترتيب الأولويات وتوسيع المعتقدات.

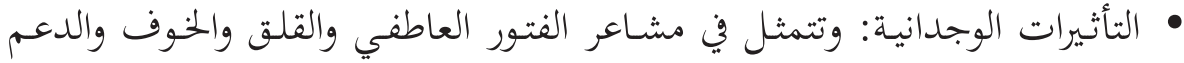
المعنوي والاغتراب وعددم الاطمئنان.

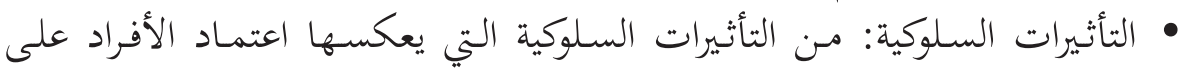

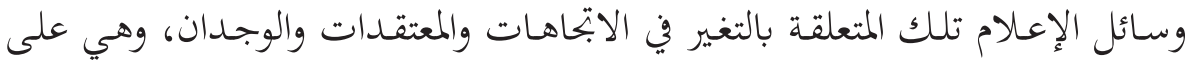

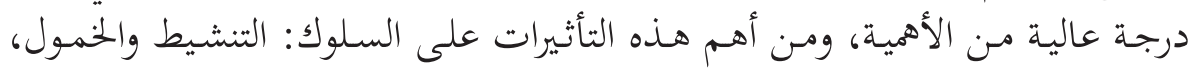

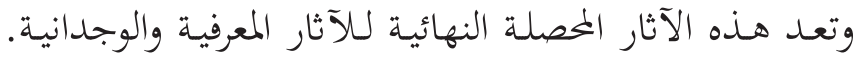

\section{توظيف نظرية الاعتماد على وسائل الإعلام في الدراسة الحالية:}

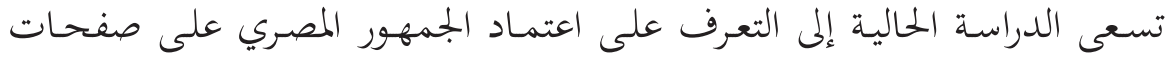

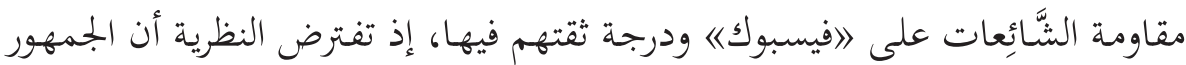

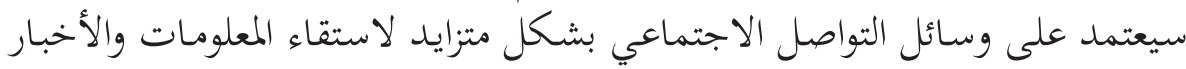

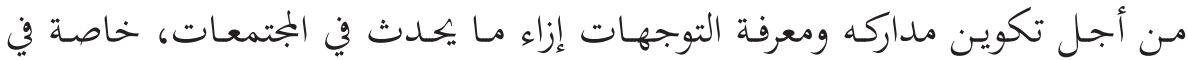

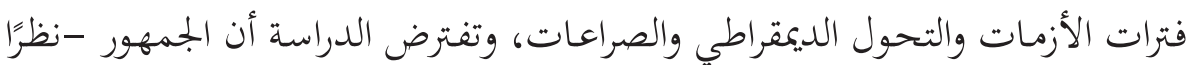

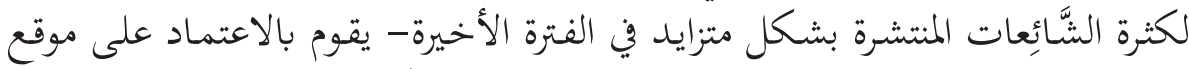
التواصل الاجتماعي للحصول على المعلومات حول الثَّائعات.

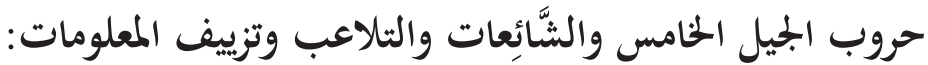

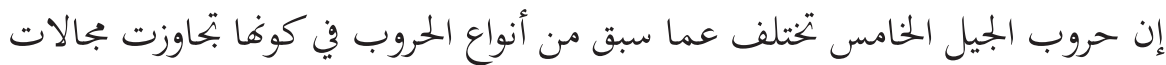

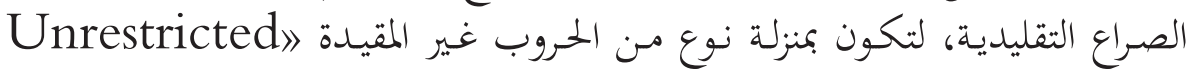
W Warfare

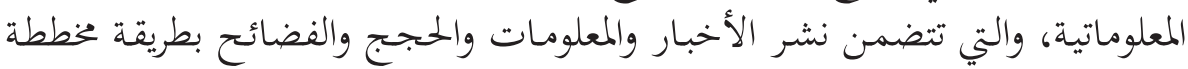

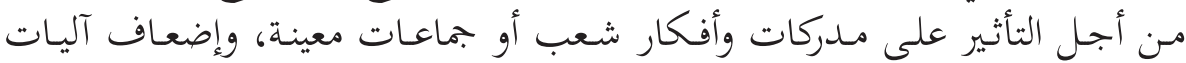

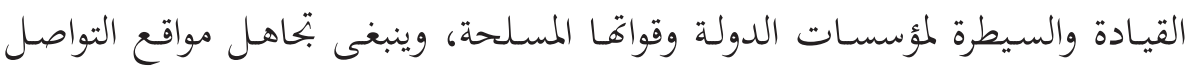

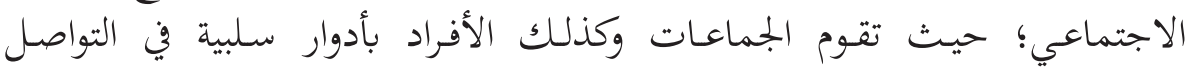

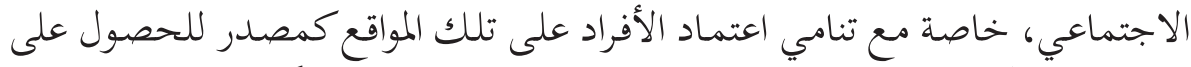

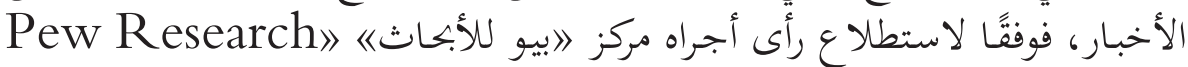

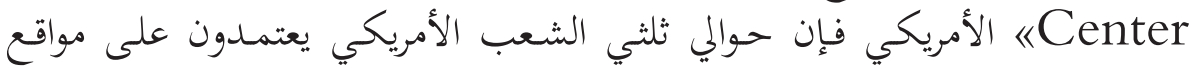

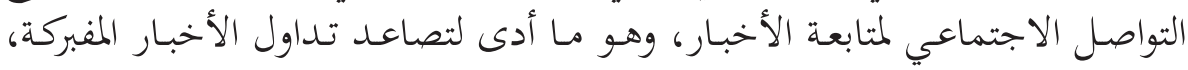


والتعامل معها مـن جانب قطاعـات واسعة مـن المتابعين باعتبارها حقائق مسلمًا كهاب(31).

Human centric» تعد حروب الجيل الخامس بمنزلة حرب تركز على الإنسان

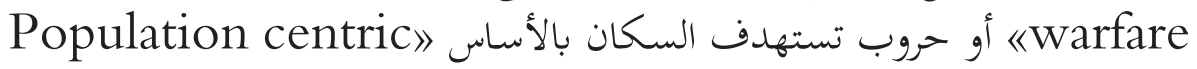
《Warfare

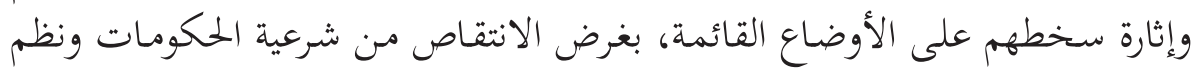
الحكم القائمة والتشكيك في مصداقية وسائل الإعلام التقليدية(32).

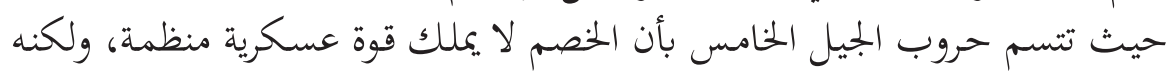

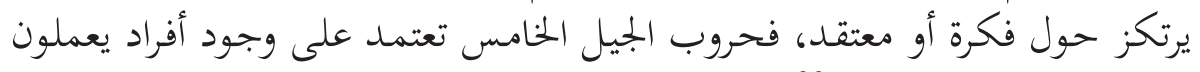

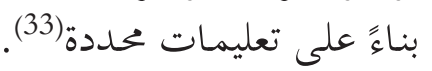

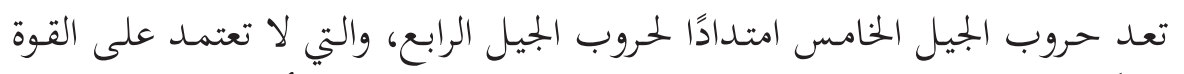

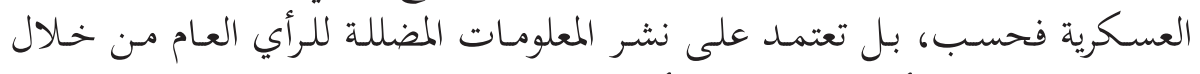

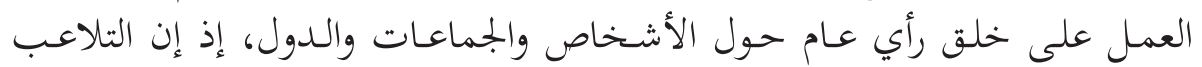

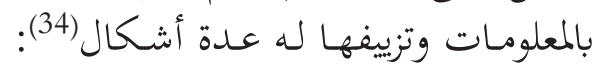

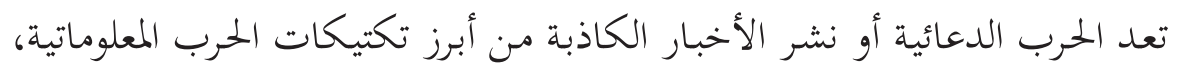

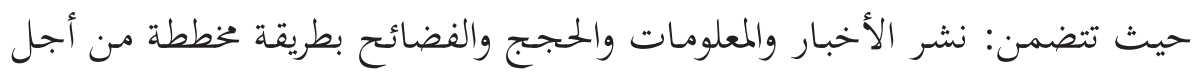

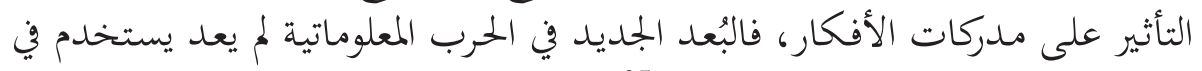
حالة الحرب، بل في حالة السلم أيضًا(35).

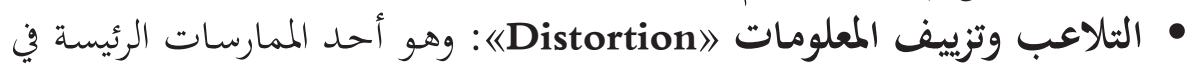

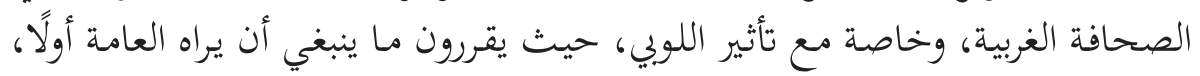

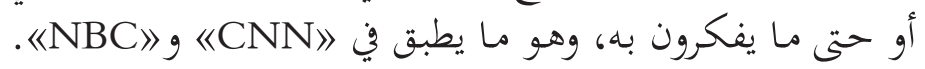

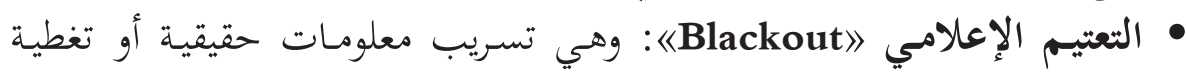

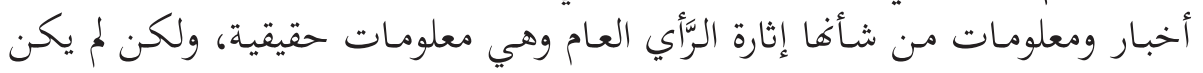
يفترض أن تظهر له مثل حرب الولايات المتحدة الأمريكية في العراق وخسائر الجيش.

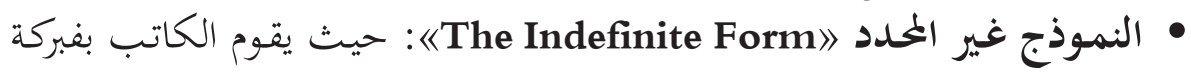

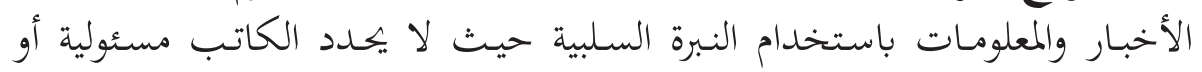
مصدر الخبر.

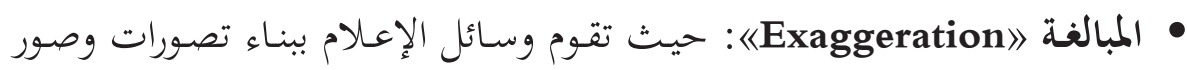

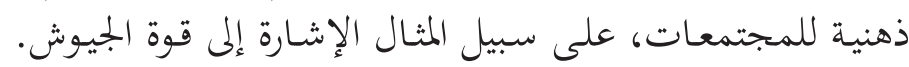

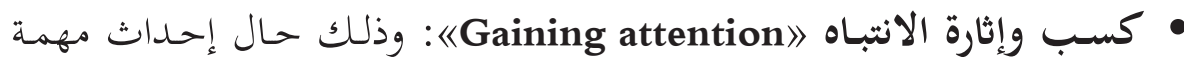


هُد أفرادًا بعينهم وتميل وسائل الإعلام إلى جذاب الرَّأي العام نوها.

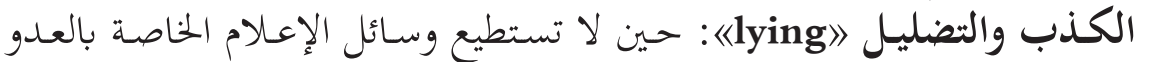

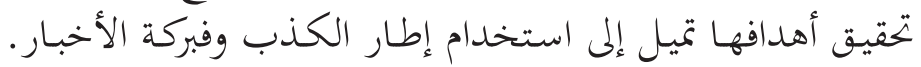

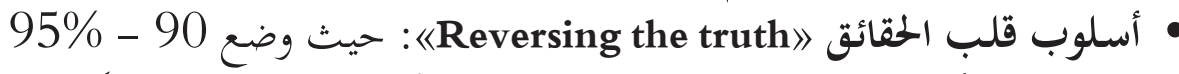
حقائق، و5 - 10\% تزييف الحقائق وهدمها لإقناع الأفراد بما يريد منتجو الشَّائعات تصديره.

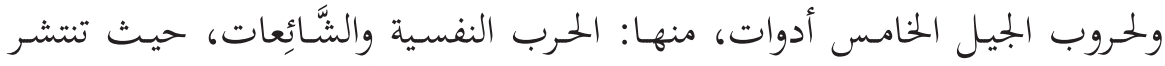

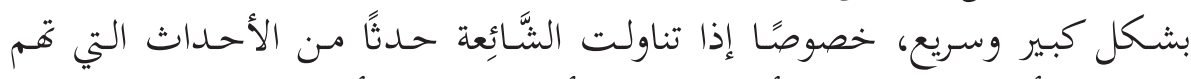

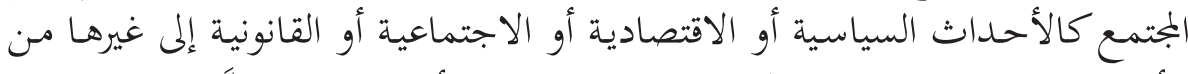

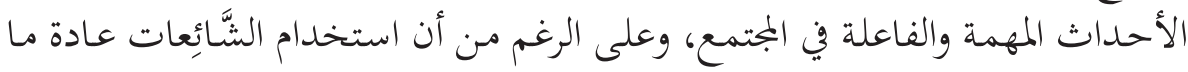

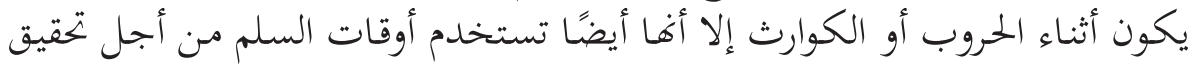

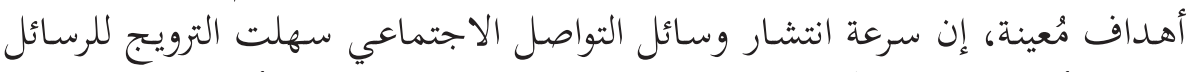

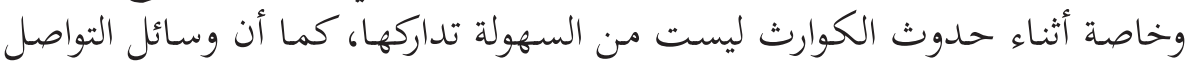

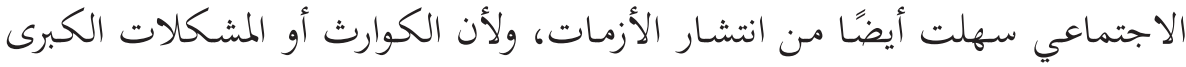

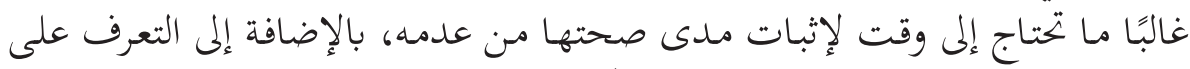

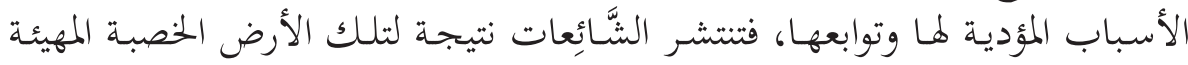

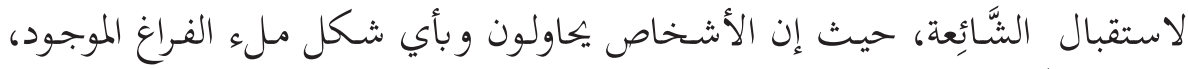

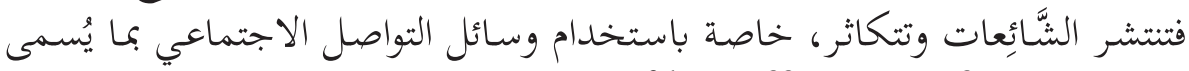
(36)《Diffusion of Rumors»

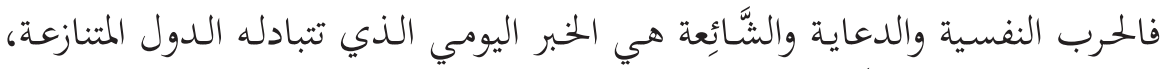

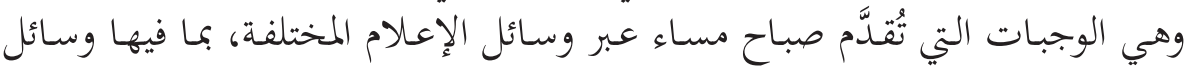

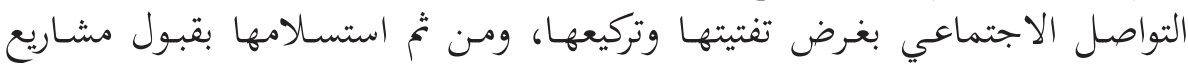

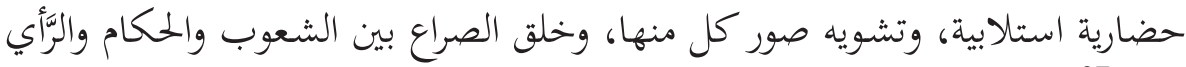
العام (37).

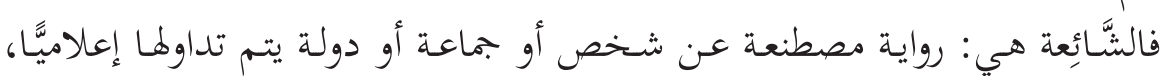

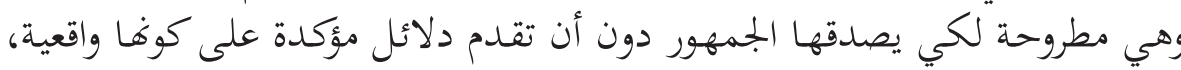

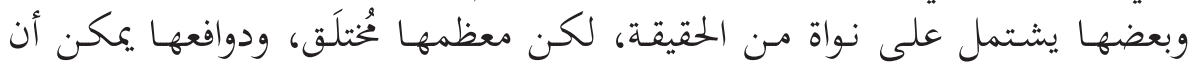

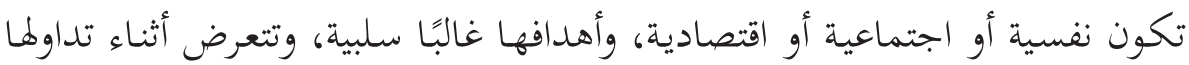

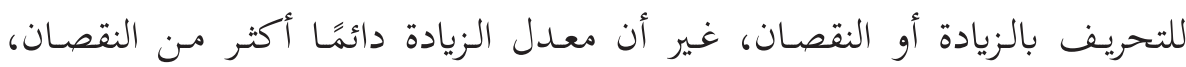

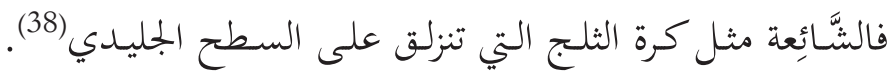




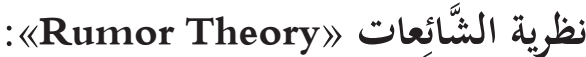

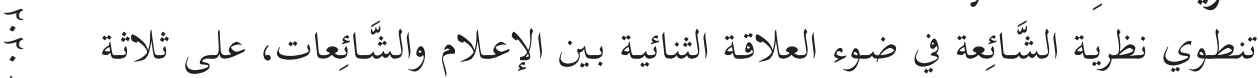

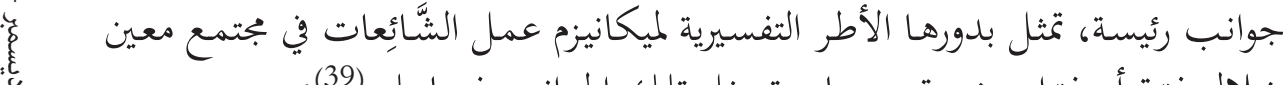

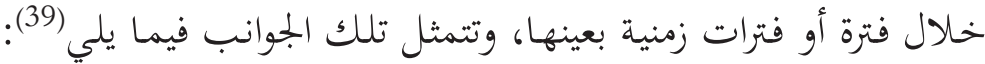

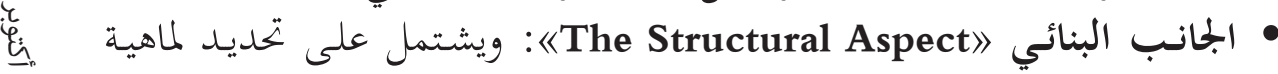

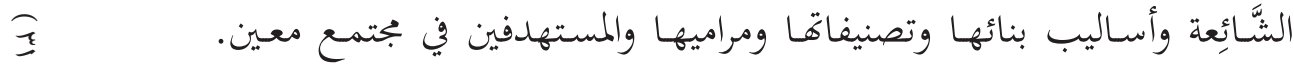
• الجانب الإجرائي 》The Operational Aspect)

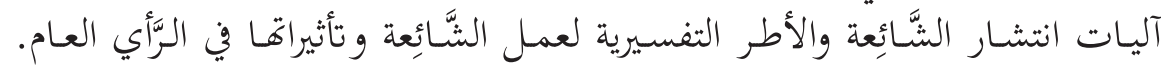

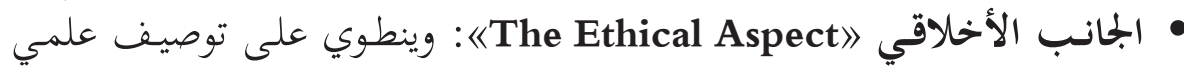

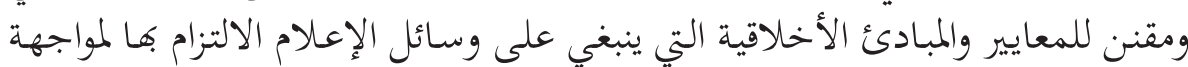

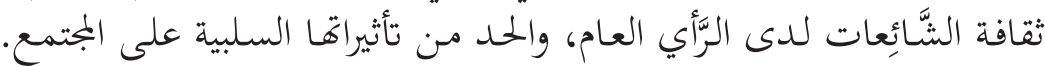

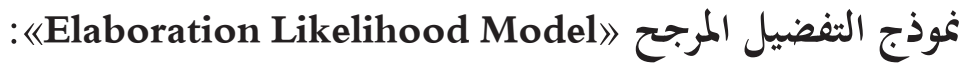

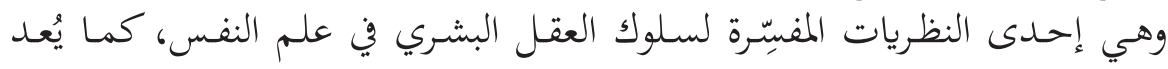

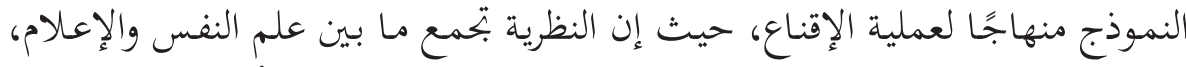

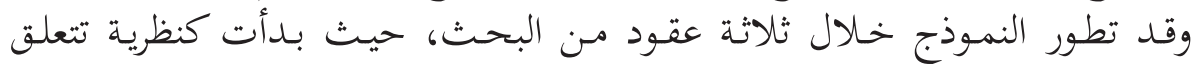

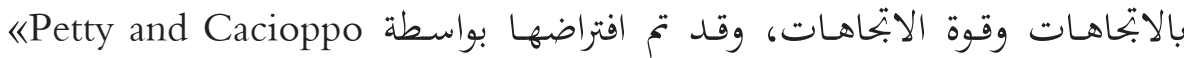

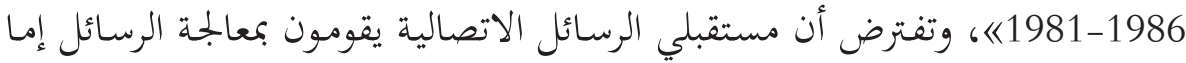

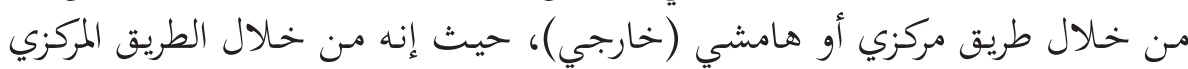

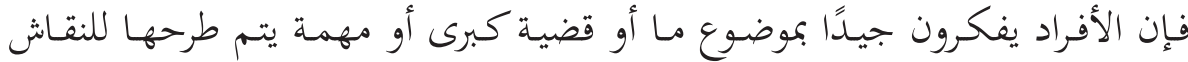

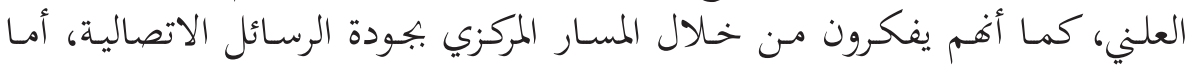

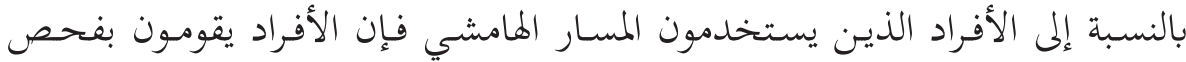

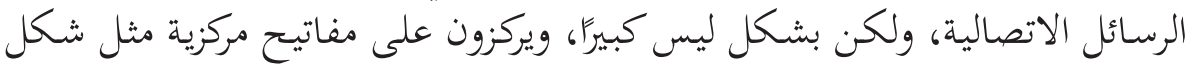

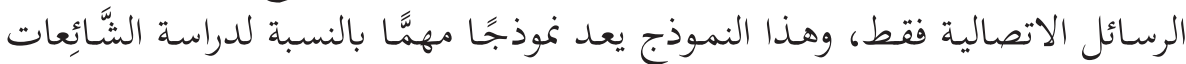

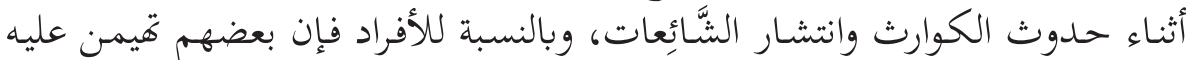

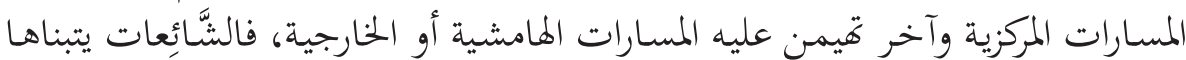

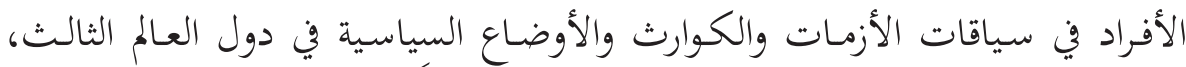

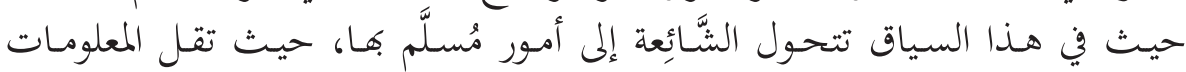
الصحيحة (40)

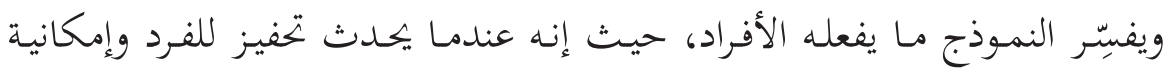

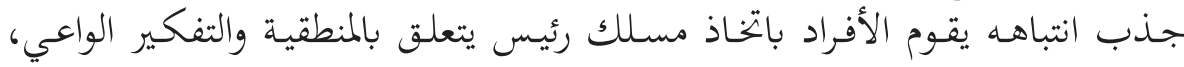




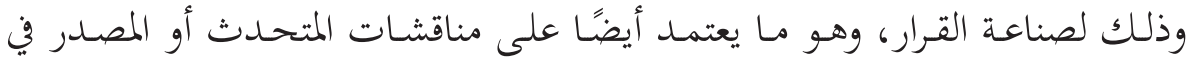

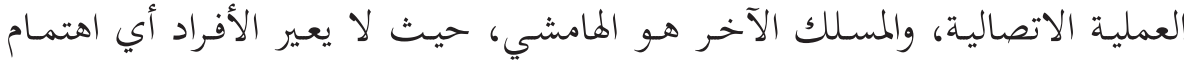

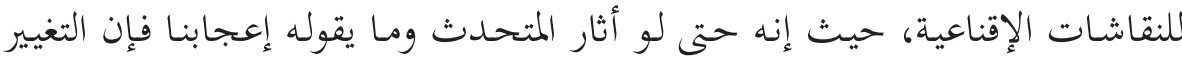
يصبح مؤقتًا وليس دائمَا (41).

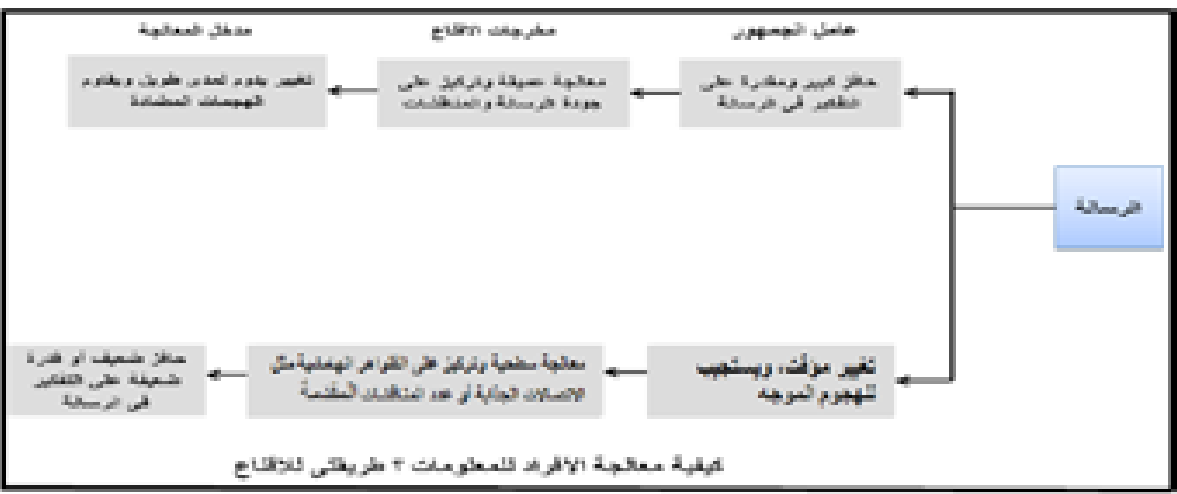

الثكل رقم (1): يوضح كيفية معالجة الأفراد للمعلومات

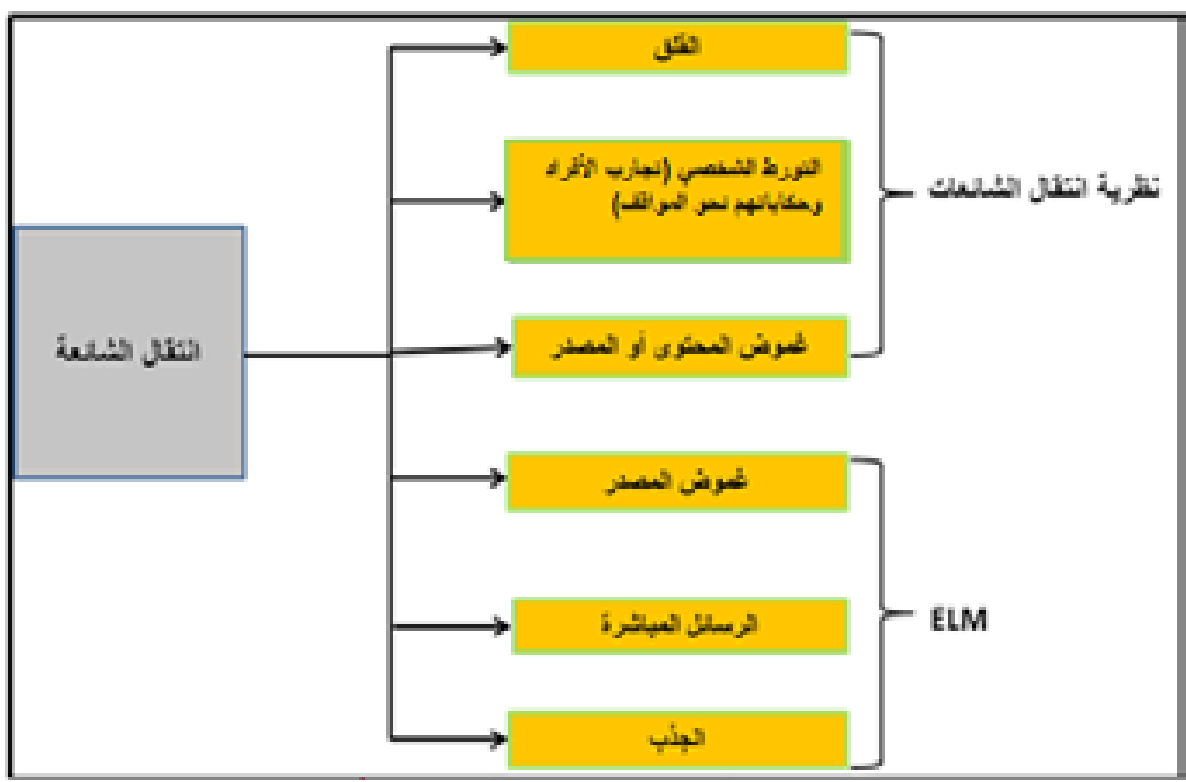

الشكل رقم (2): يوضح كيفية انتقال الثَّائعات 
تنتمي الدراسة إلى الدراسات الوصفية التحليلية التي تستهدف تفسير وتحليل البيانات

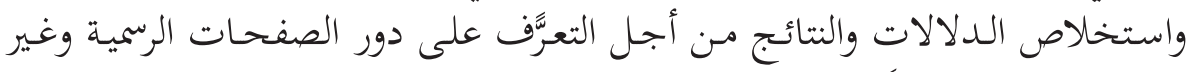

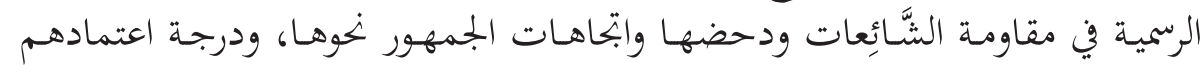

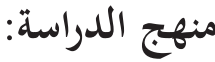

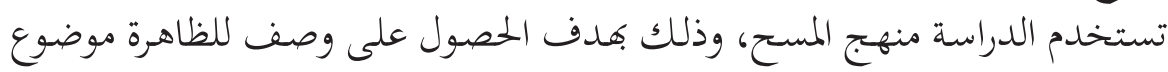

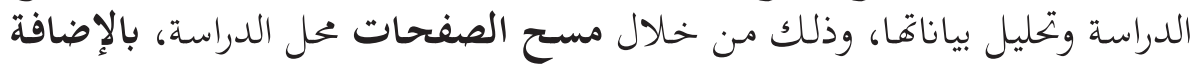

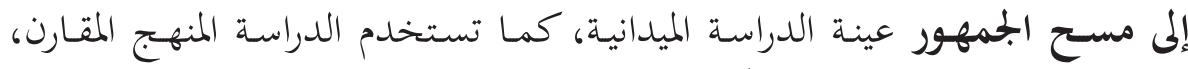

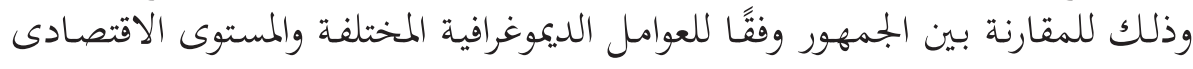

والاجتماعي.

مبررات اختيار عينة الدراسة:

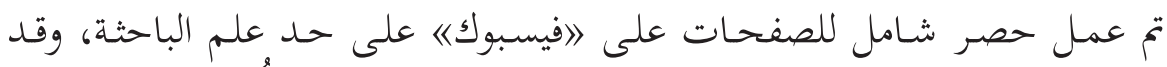

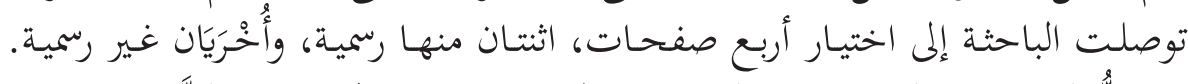

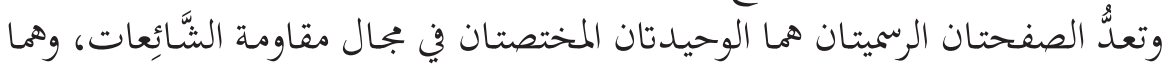

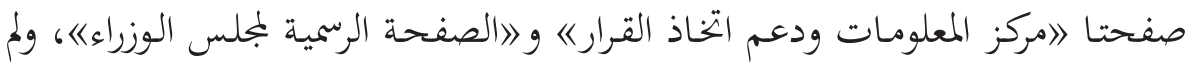

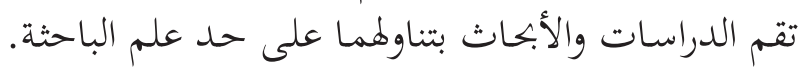

أما بالنسبة للصفحتين غير الرسميتين فقد تم اختيارهما على أساس:

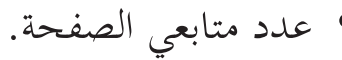

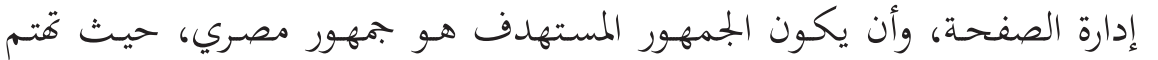

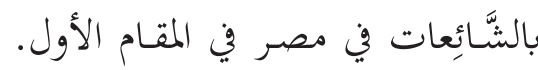

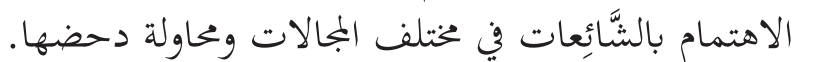

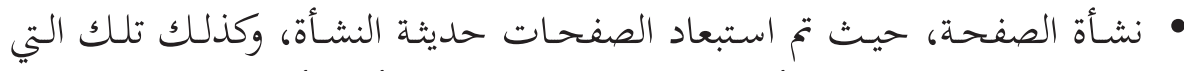

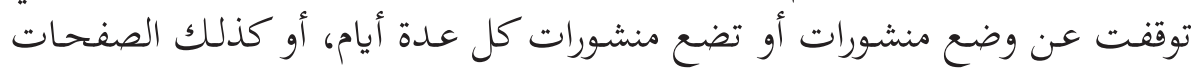

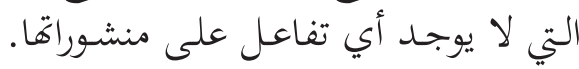

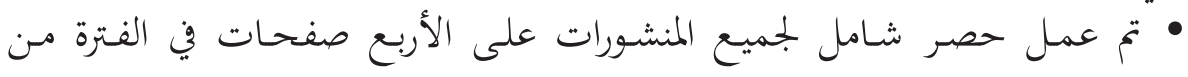


2019/1/1 وحتى 2019/6/1، حيث بلغ عدد الشَّائعات التي تم تحليلها 421

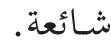

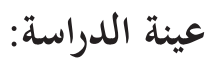

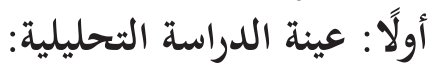

أجرت الباحثة الدراسة على 421 منشورًا من منشورات 》افيسبوككية في الفترة الزمنية من يناير 2019 حتى يوليو 2019.

\section{عدد المواد المنشورة على صفحات مقاومة الشائعات}

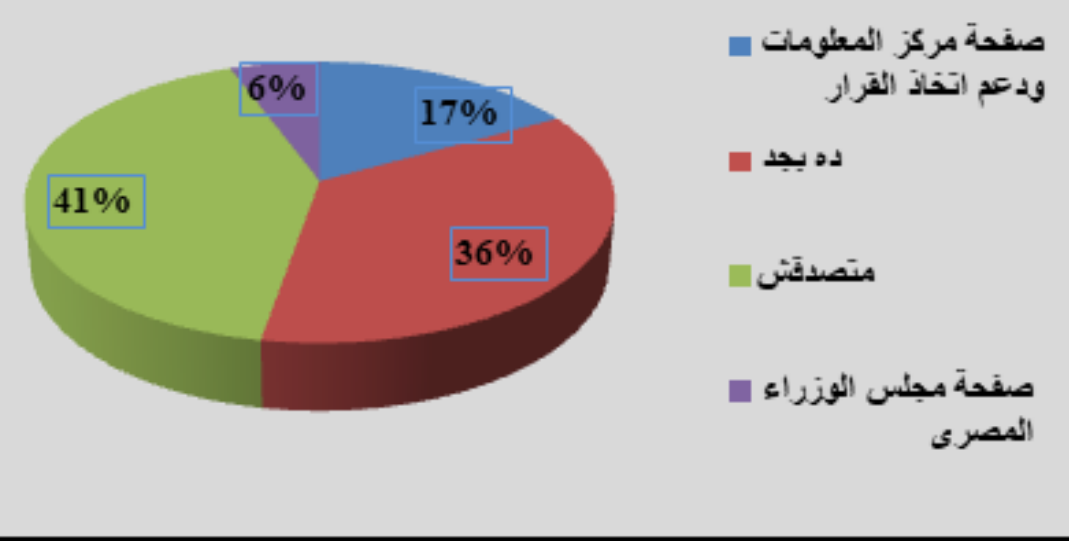

الشكل رقم (3): يوضح عدد المواد المنشورة على صفحات مقاومة الشَّائعات

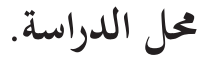

ثانيًا: عينة الدراسة الميدانية: - مينة

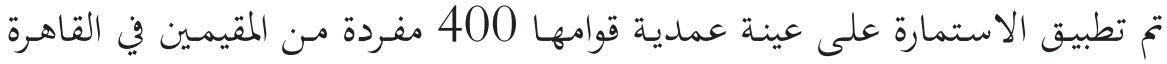

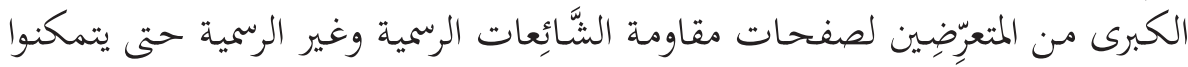

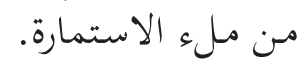
وفيما يلي توصيف لعينة الدراسة: 


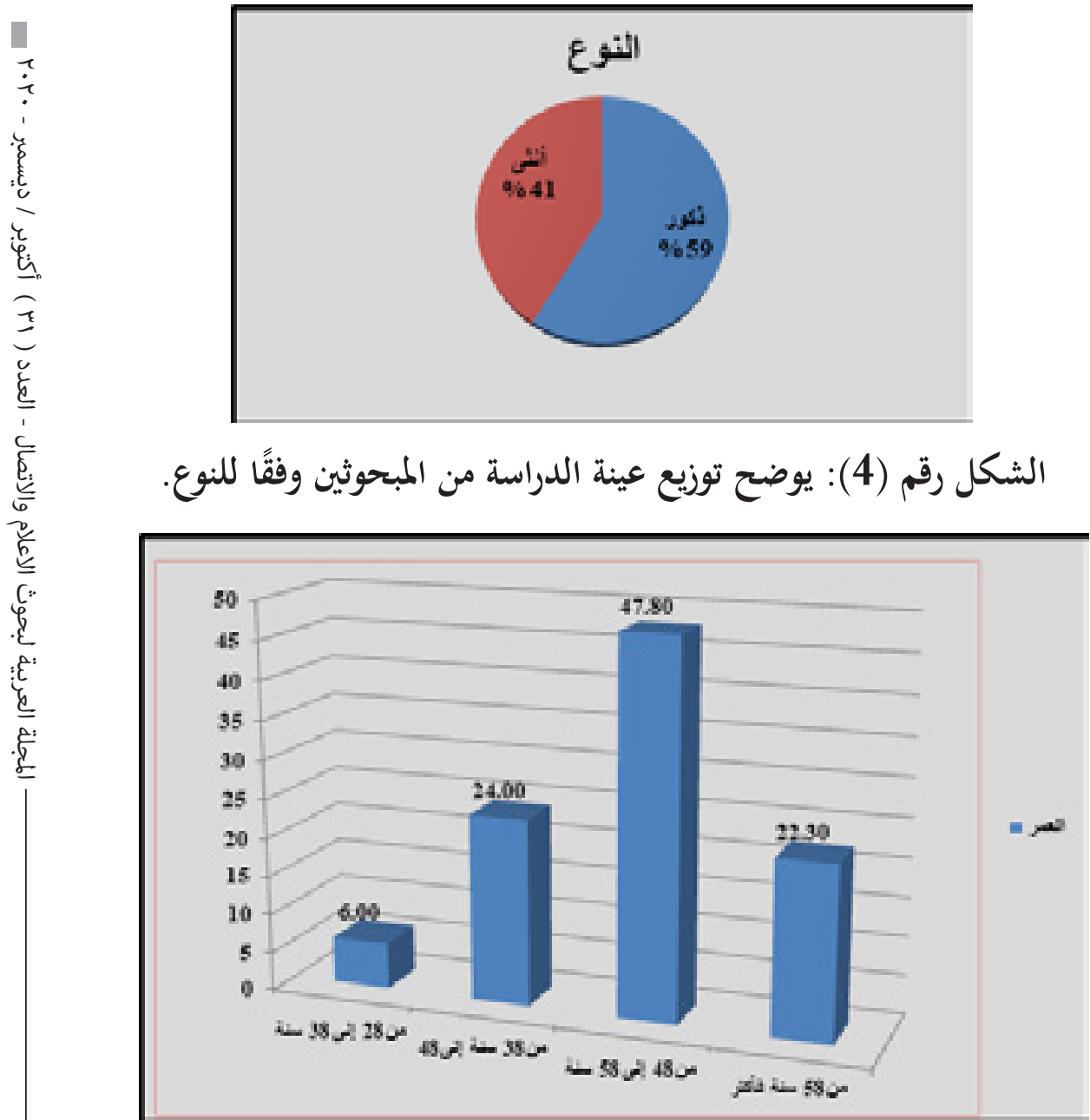

الشكل رقم (5): يوضح توزيع عينة الدراسة من المبحوثين وفقًا للعمر. 


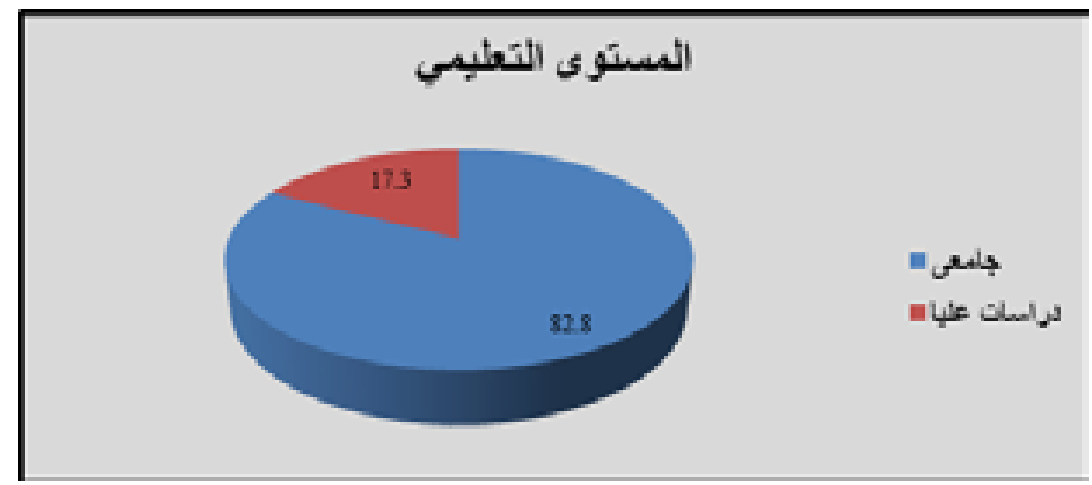

الشكل رقم (6): يوضح توزيع عينة الدراسة من المبحوثين وفقًا للمستوى

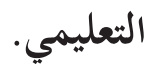

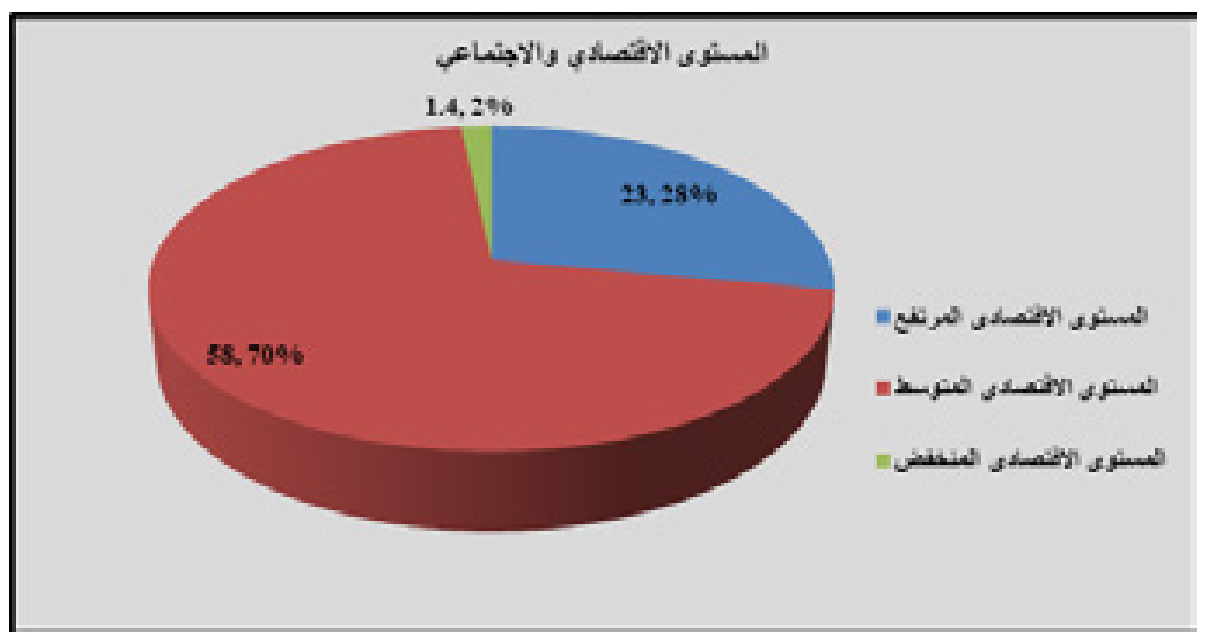

الشكل رقم (7): يوضح توزيع عينة الدراسة من المبحوثين وفقًا للمستوى الاقتصادي والاجتماعي.

فئات تحليل المضمون: (التعريفات الإجرائية لفئات تحليل المضمون)

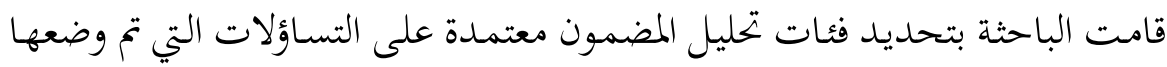

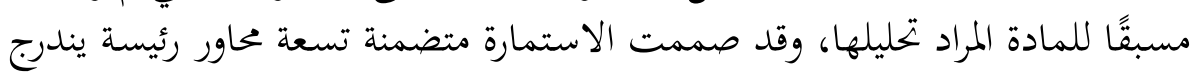

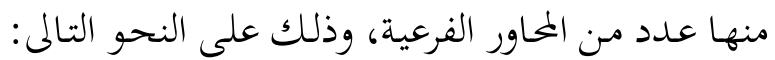

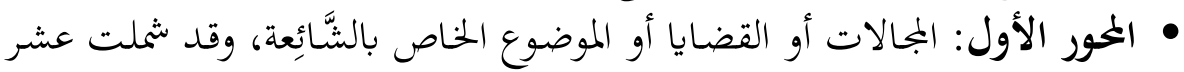

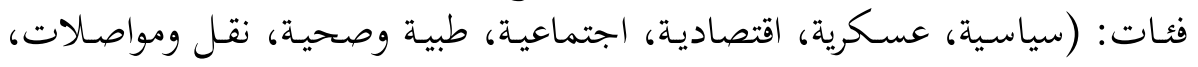


تموين وغذاء، إداري وتنظيمي، حوادث وجرائم، فئة أخرى تشمل: ديني، رياضي، اهتمامات إنسانية، ...).

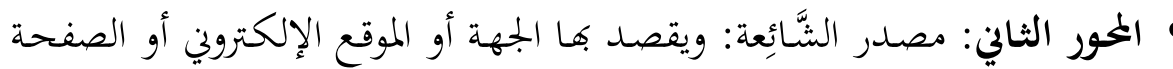

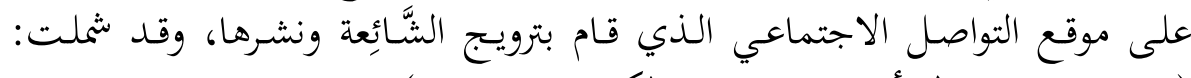

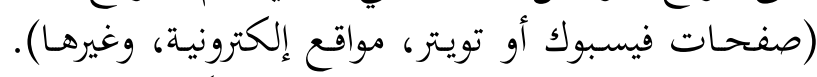

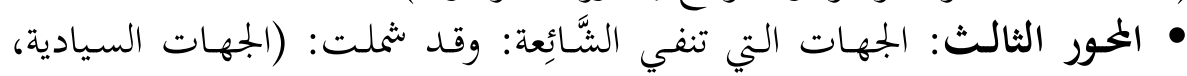

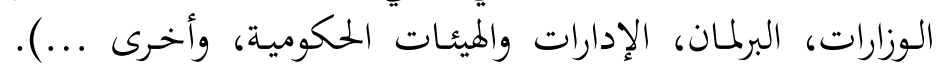

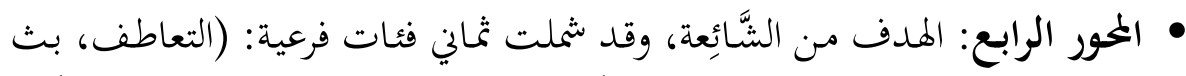

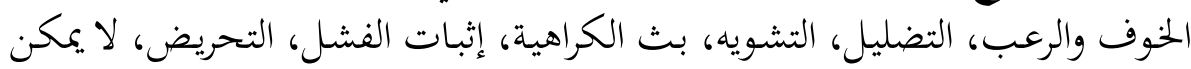
تحديده).

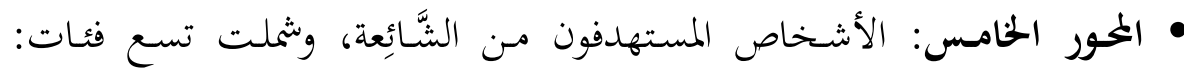

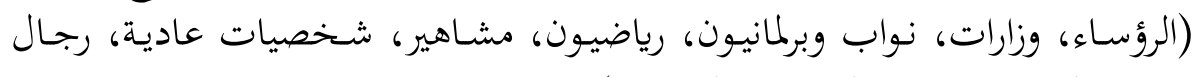

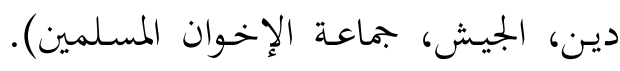

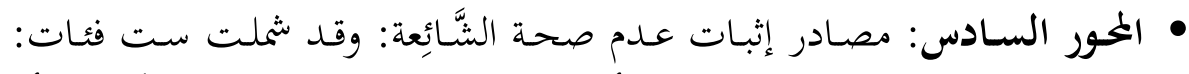

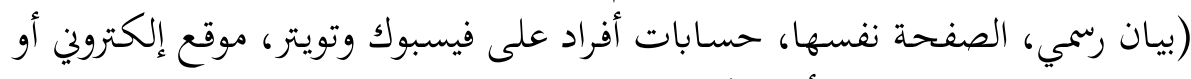

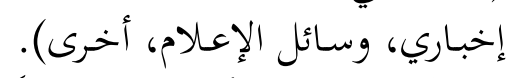

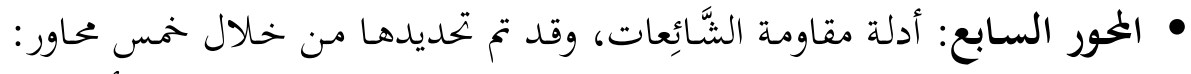

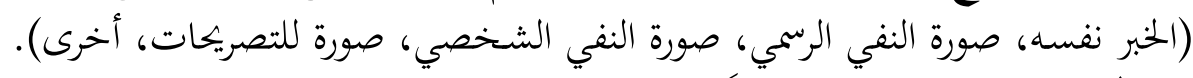

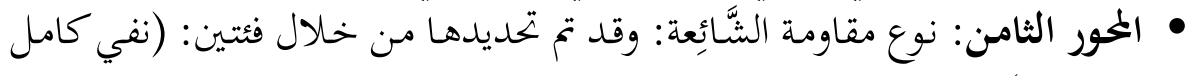
، نفي جزئي).

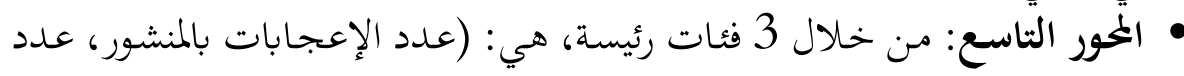
التعليقات على المنشور، عدد المشاركات للمنشور).

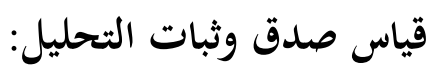

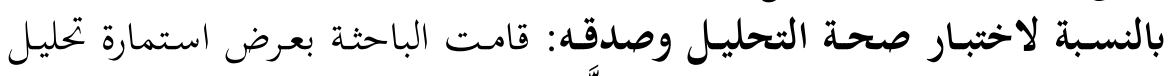

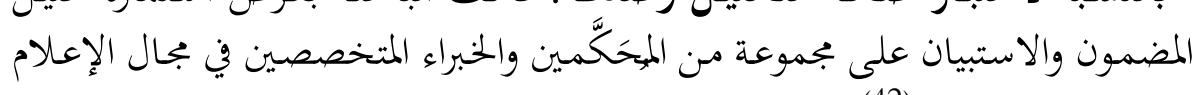

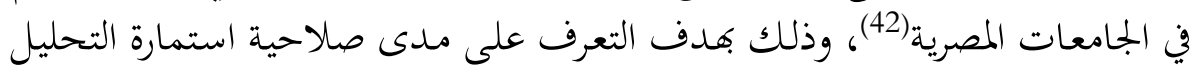

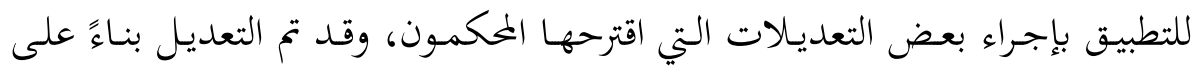

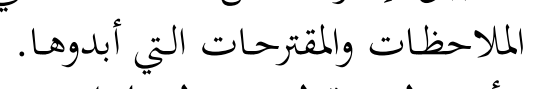
أما بالنسبة لثبات التحليليل: فقد قام الباحث باتبات البـاع أسلوب إعادة الاختبار 
《Re-test》

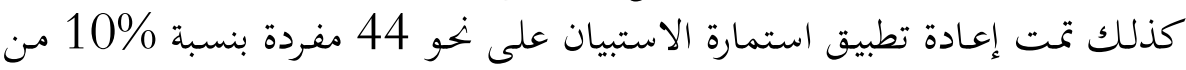

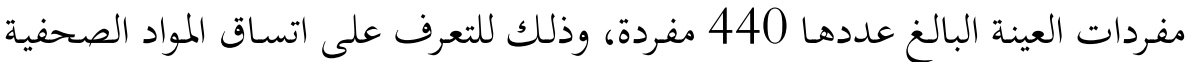

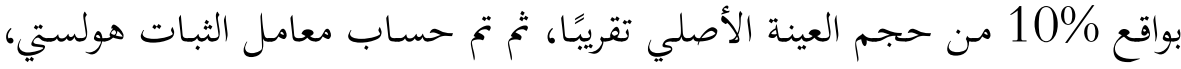

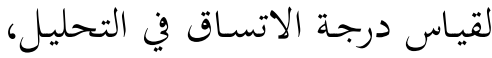

$$
\text { حيث معامل الثبات هولستي: }
$$

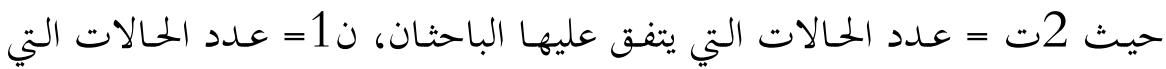

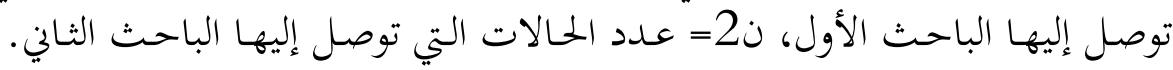

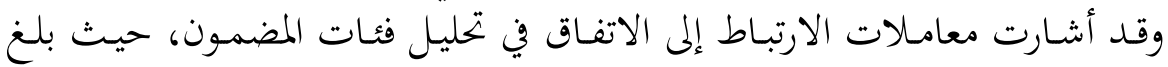

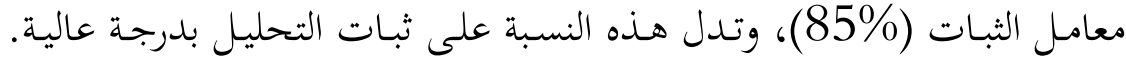

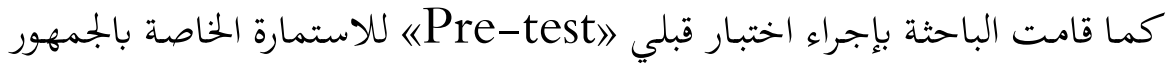

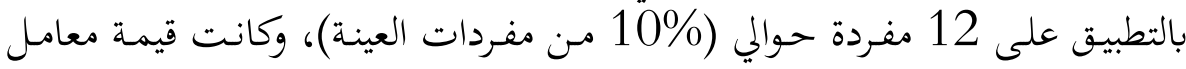

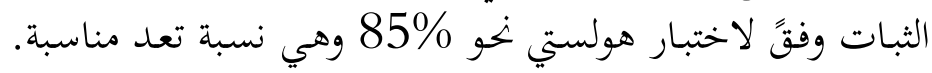

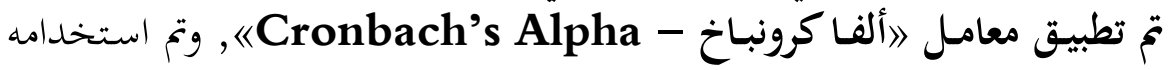

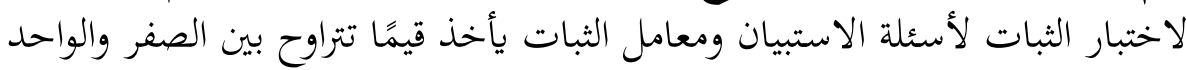

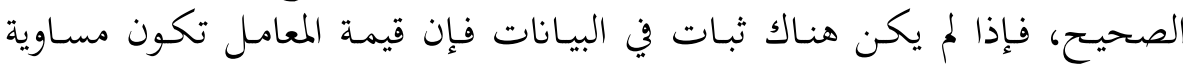

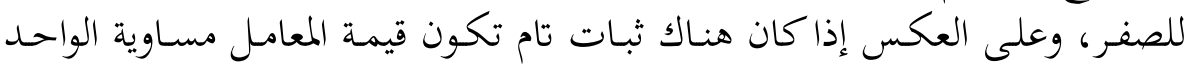

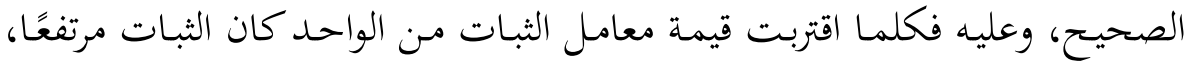

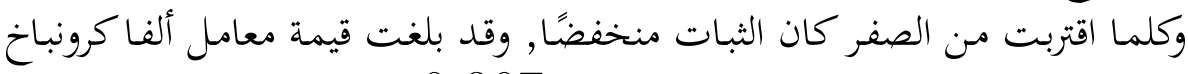

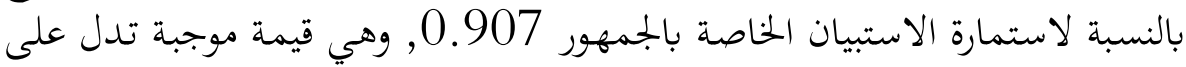

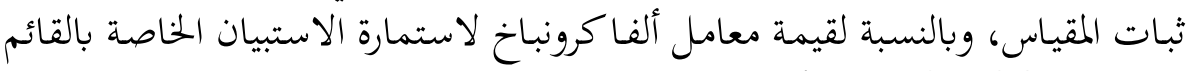

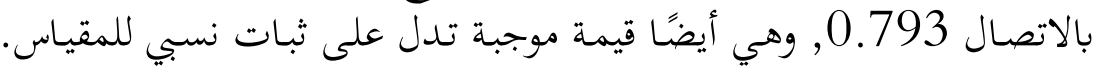

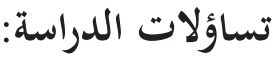

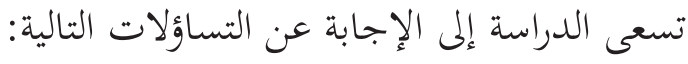

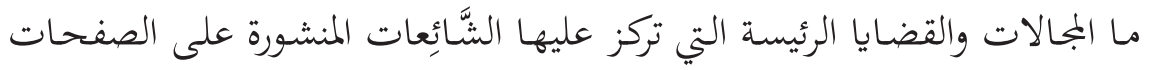

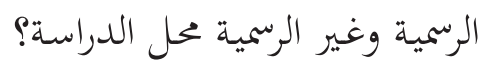

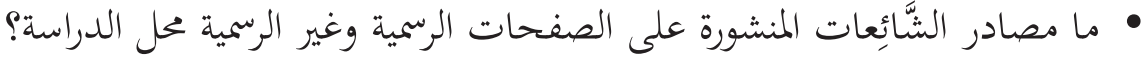

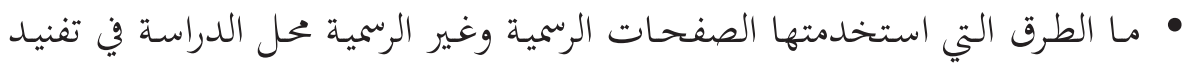




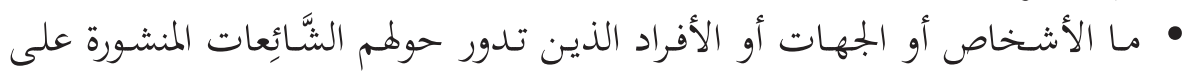

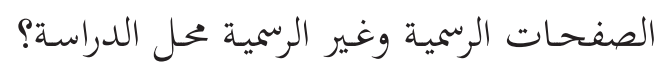

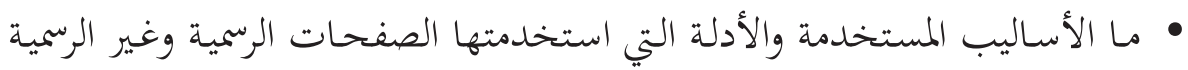

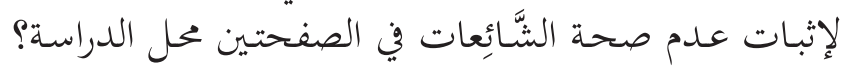

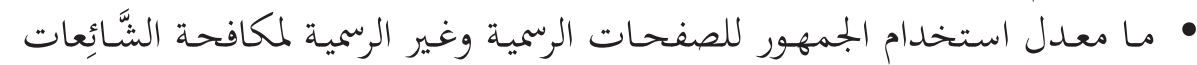

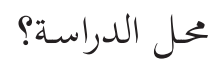
• مـا دوافع الاعتماد على الصفحات الرسمية وغير الرسمية محل الدراسة والاستعانة كها لمكافحـة الشَّائعات؟

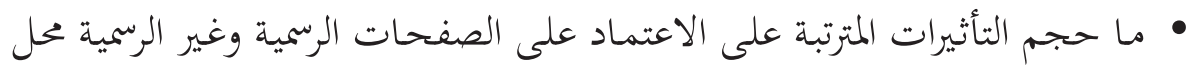
الدراسة؟ هاسج

(") • مـا المصادر التي يعتقـد المبحوثون أهـا تساعد على انتشـار الشَّائعات في المجتمع المصري؟ • مـا مقـدار الثقـة في الأخبـار والمعلومات المنشورة حول دحض الشَّائِعات على

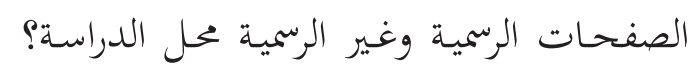

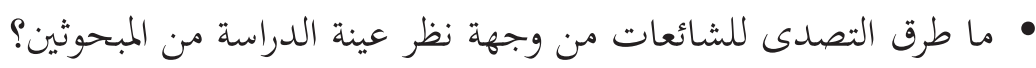

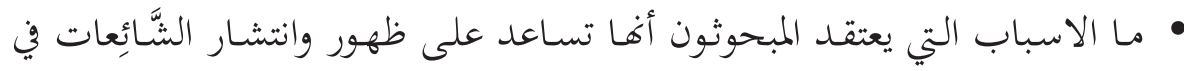

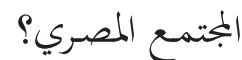
• مـا آليات حروب المهري؟ الجيل الخامس المستخدمة في نشر الشَّائعات مـ وجهـة نظر الجمهور؟ مألمات

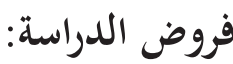

\section{أولاً: فروض الفوض الدراسة: التور التحليلية:}

الفرض الأول: توجـد علاقة دالة إحصائيًا بين القضايا أو المجالات التهات التي تناولتها

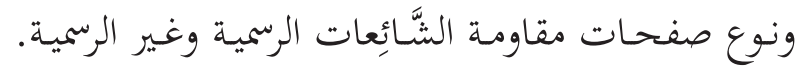

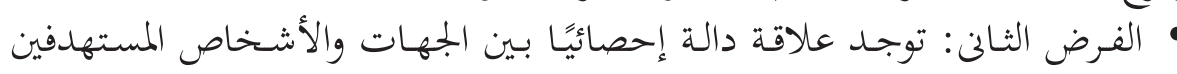

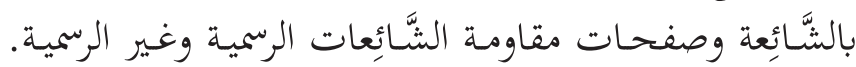

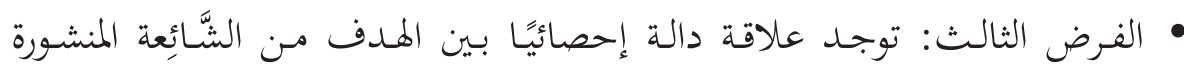

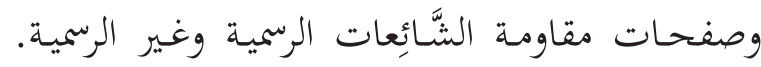


ثانيًا: فروض الدراسة الميدانية: • الفرض الأول: توجد فروق النيًا: فروالمة دالة إحصائيًا بين كل مـن النوع ودرجـة الثقـة في

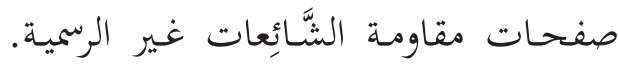

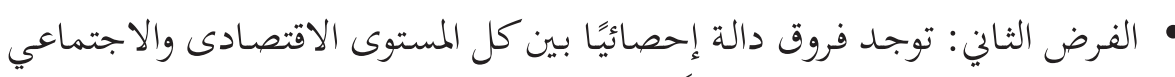

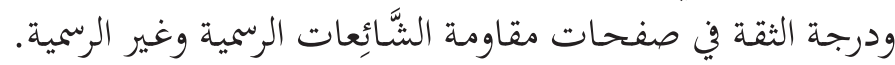

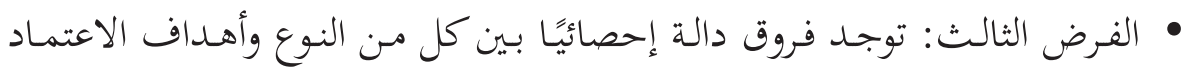

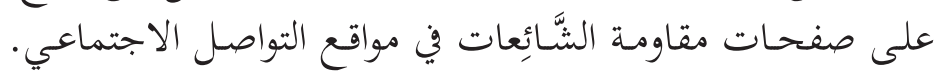

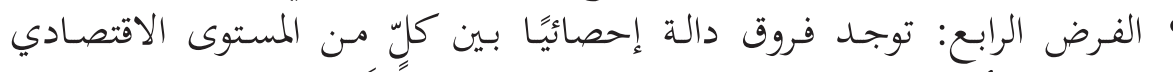

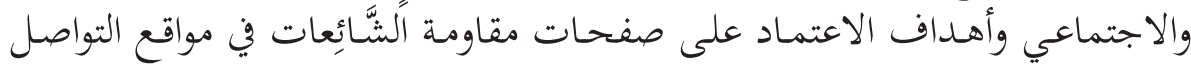

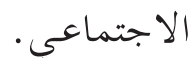

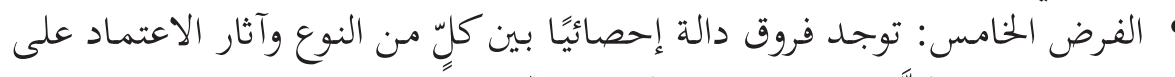

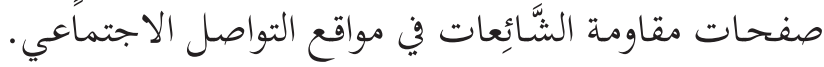

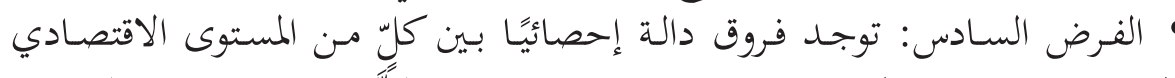

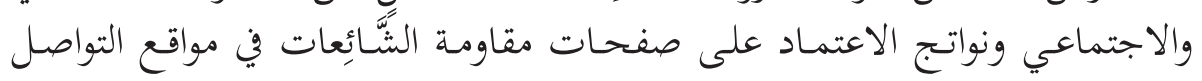

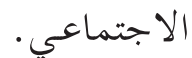

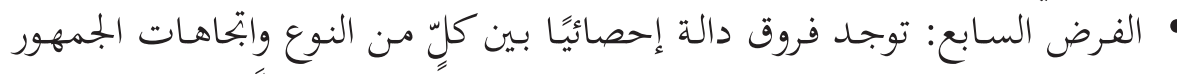

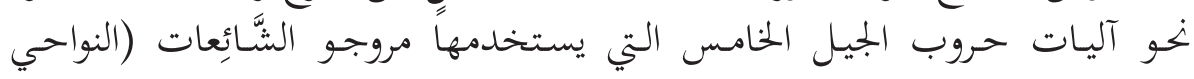

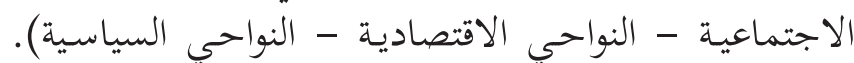

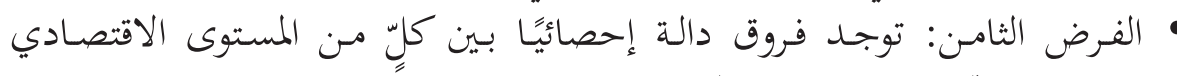

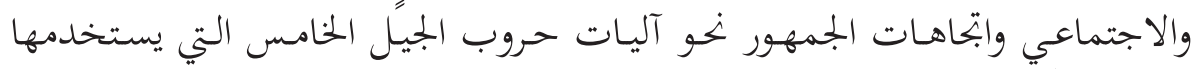
مروجو الشَّائِعات (النواحي الاجتمات الجماعية - النواحي الاقتصادية - النواحي السياسية).

\section{المعالجة الإحصائية للبيانات:}

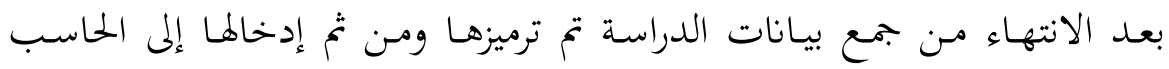

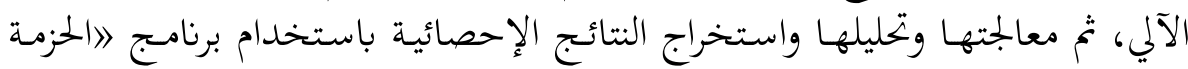

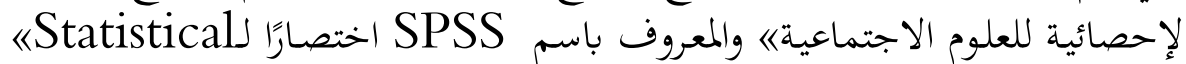
.Package For the Social Sciences» وتم اللجوء إلى المعاملات والاختبارات الإحصائية الآتية في تحليل بيانات الدراسة: • التكرارات البسيطة والنسب المئوية. المتوسطات الحسابية والانحرافات المعيارية. 
• اختبارات كا2 (Chi Square) لدراسة الدلالة الإحصائية للعلاقة بين متغيرين

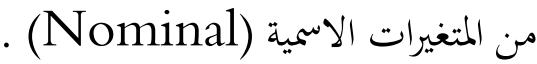

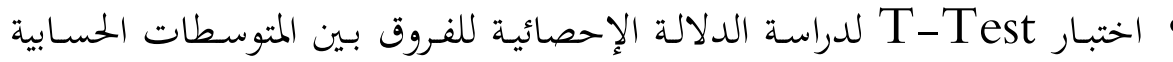

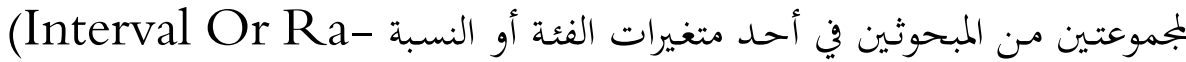
.tio)

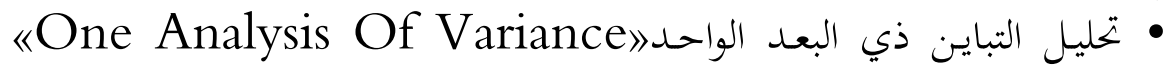

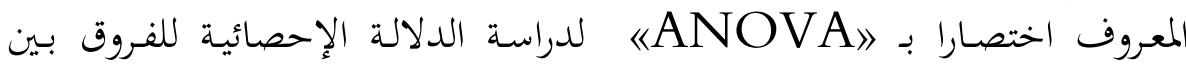

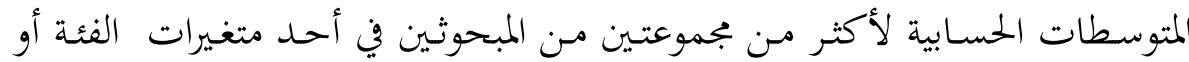
النسبة «Interval Or Ratio»

\section{منهجية قياس متغيرات الدراسة:}

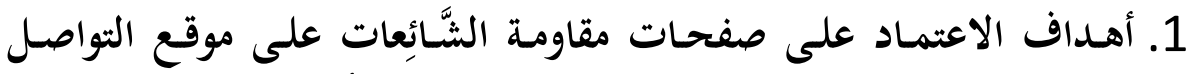

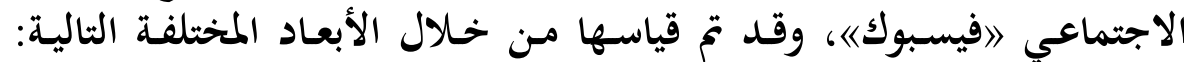

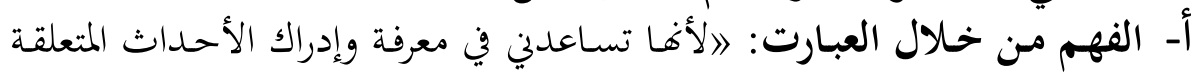

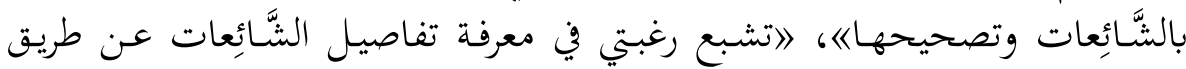

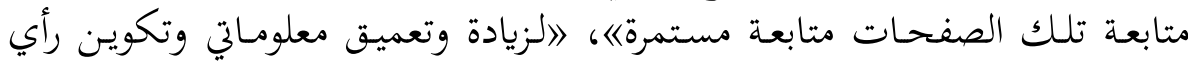

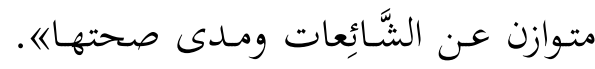

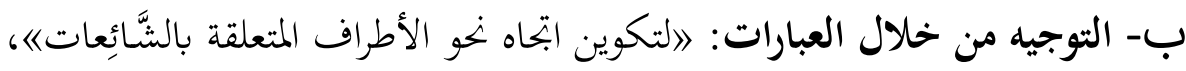

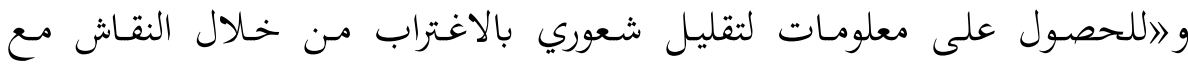

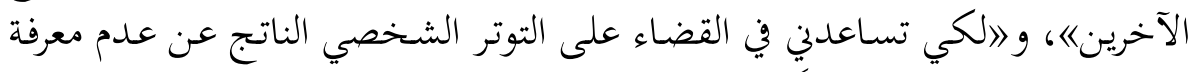

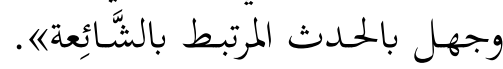

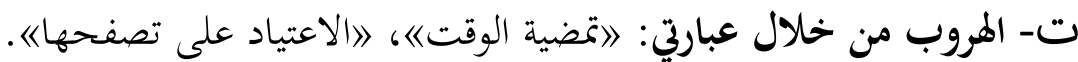

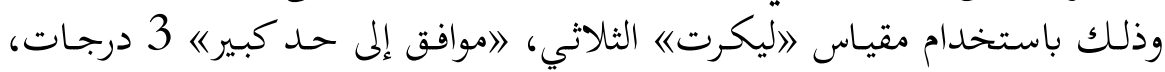

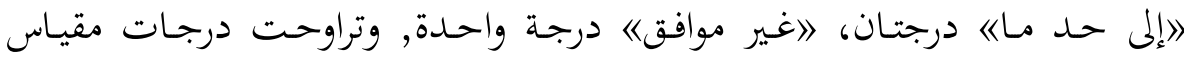

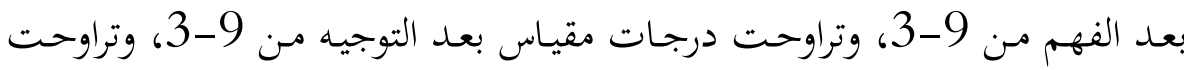

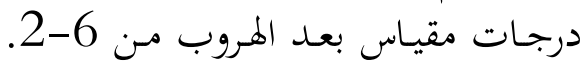

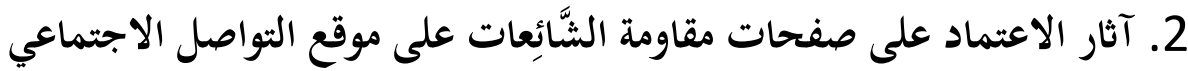

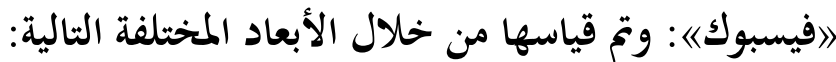

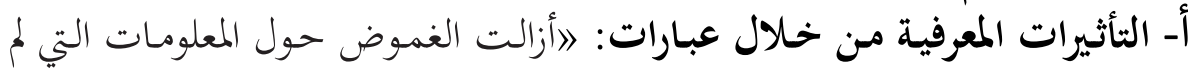

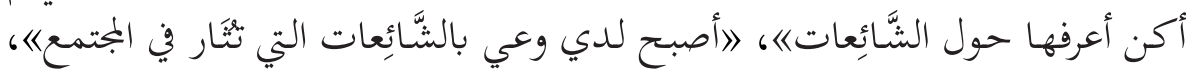


》أصبحت أكثر وعيًا وقمت بمشاركة المنشورات المتعلقة بالشَّائعات ونفيها والخاصة

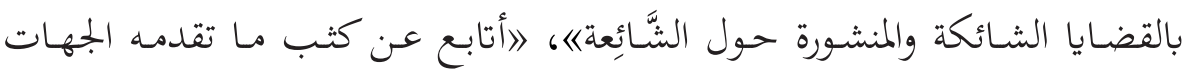

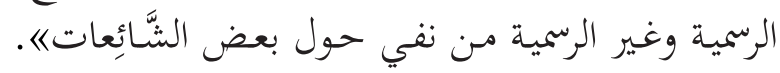

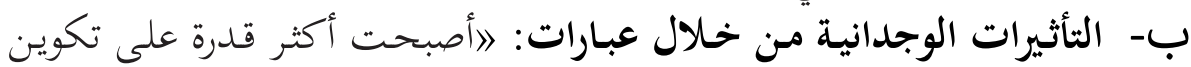

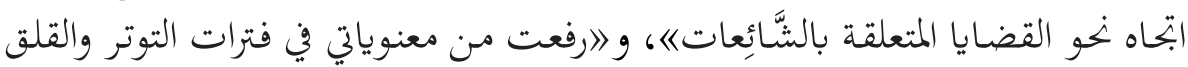

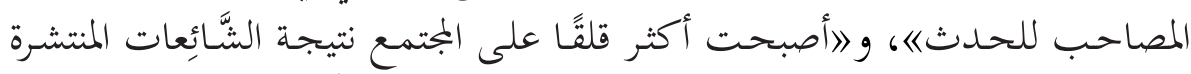

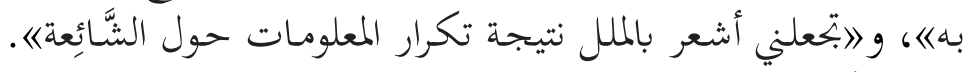

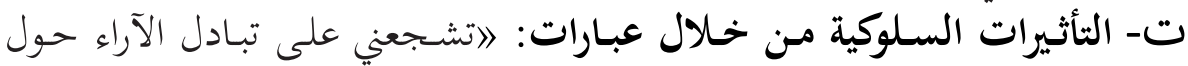

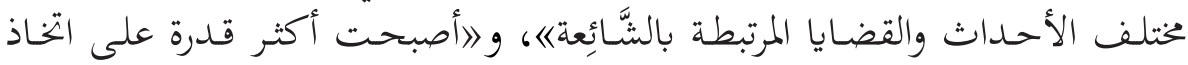

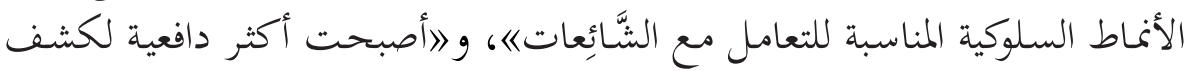

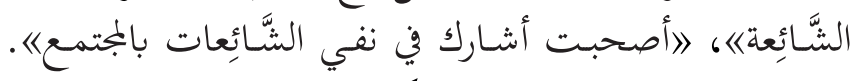

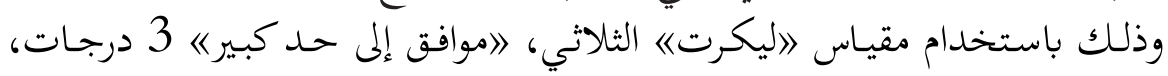

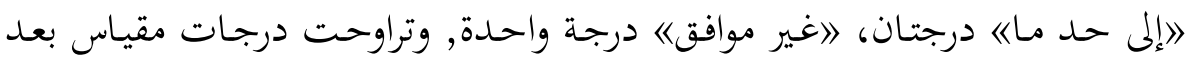

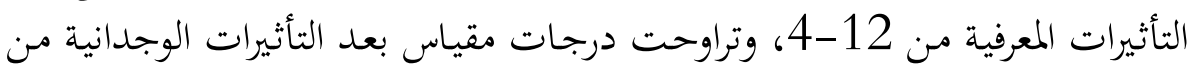

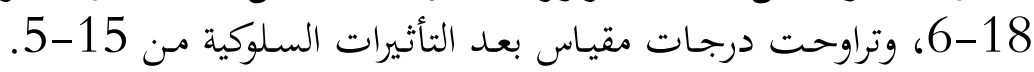

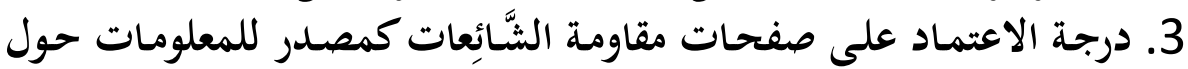

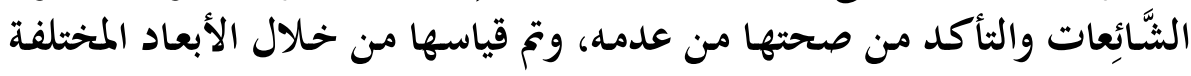
التالية:

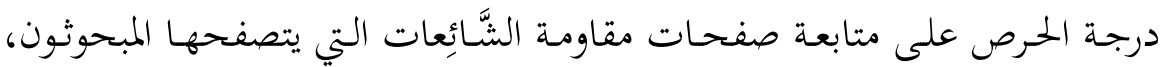

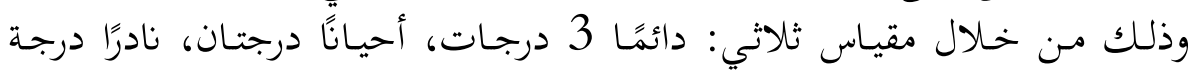

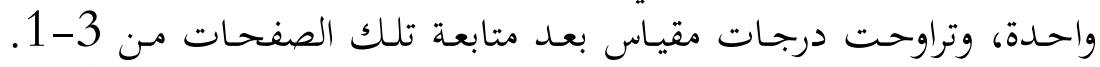

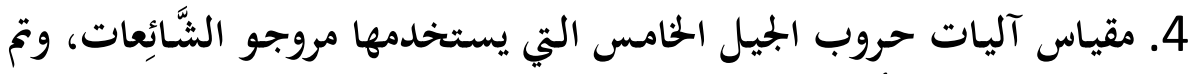

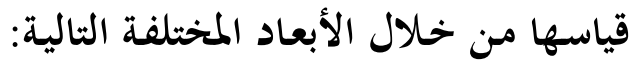

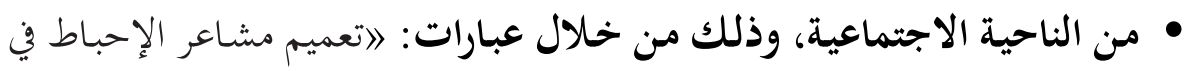

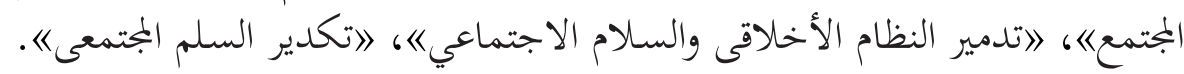

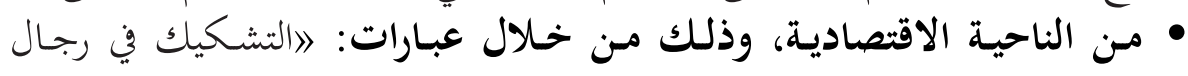

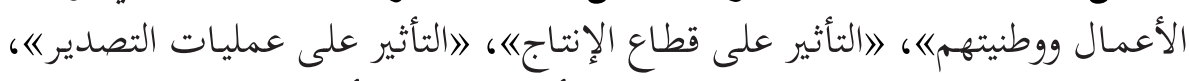

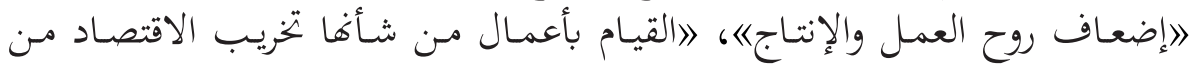

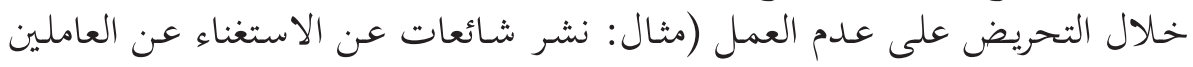

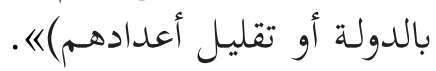


من الناحية السياسية، وذلك من خلال عبارات: الصناعة الأزمات والارتباك في

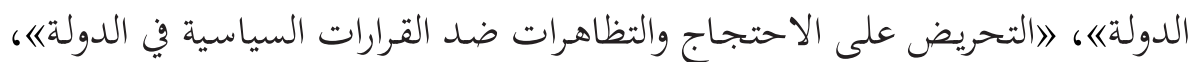

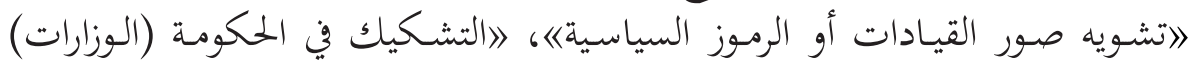

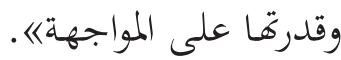

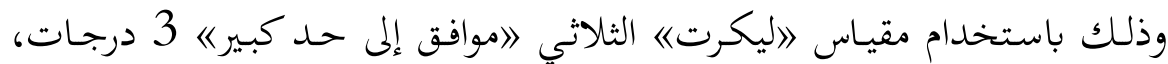

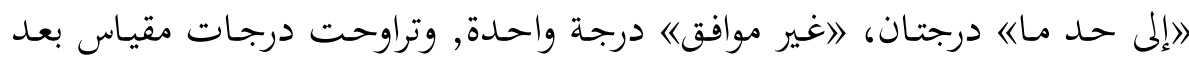

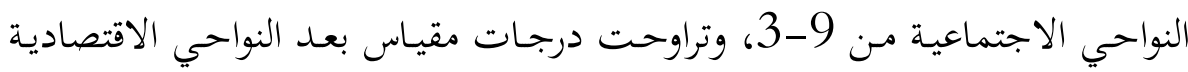

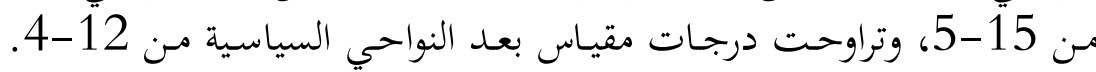
5. مقياس المستوى الاقتصادي:

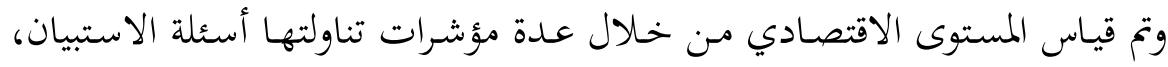

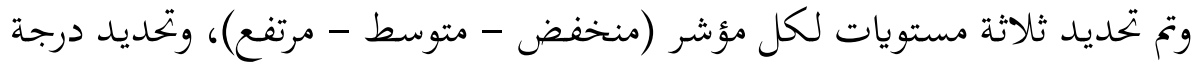

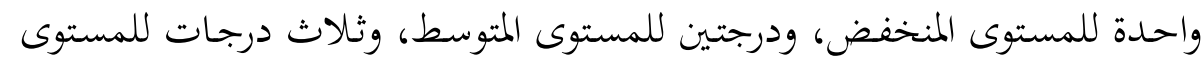

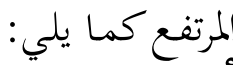

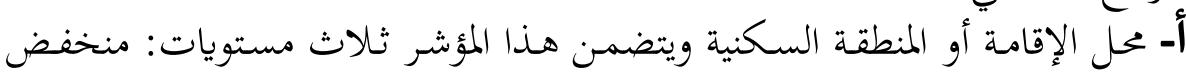

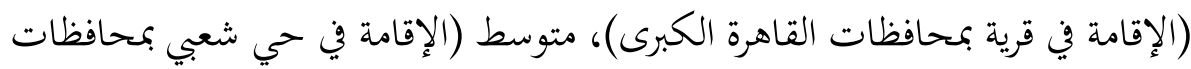

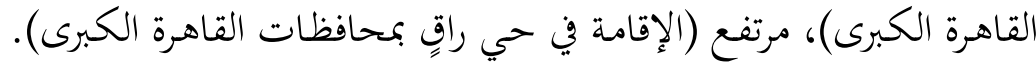

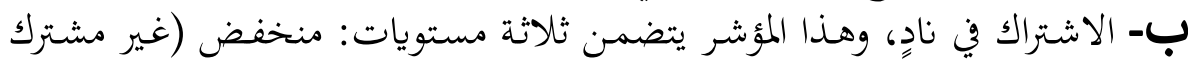

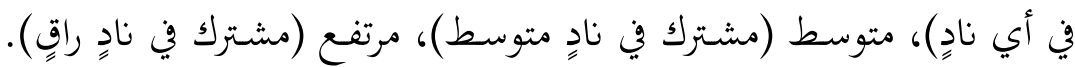

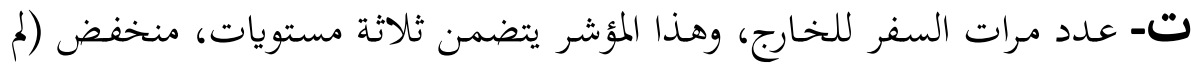

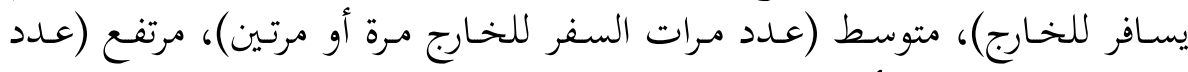
مرات السفر للخارج أكثر مـن اثنين).

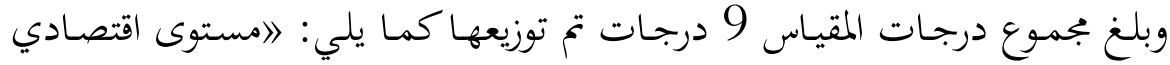

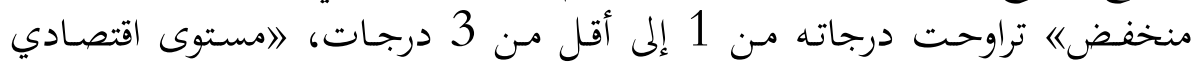

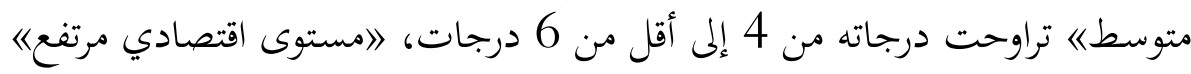

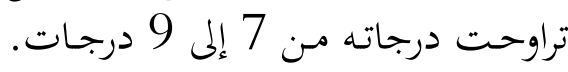

\section{أولًا: نتائج الدراسة التحليلية}

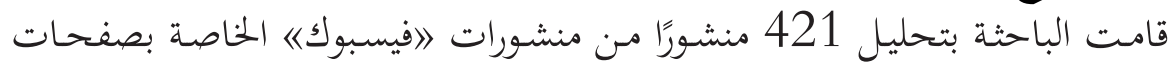

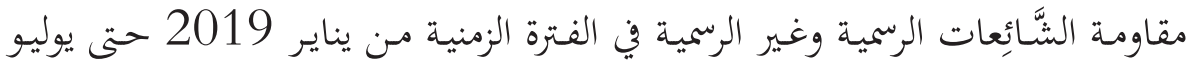


1. القضايا أو المجالات المنشورة في صفحات مقاومة الشَّائعات.

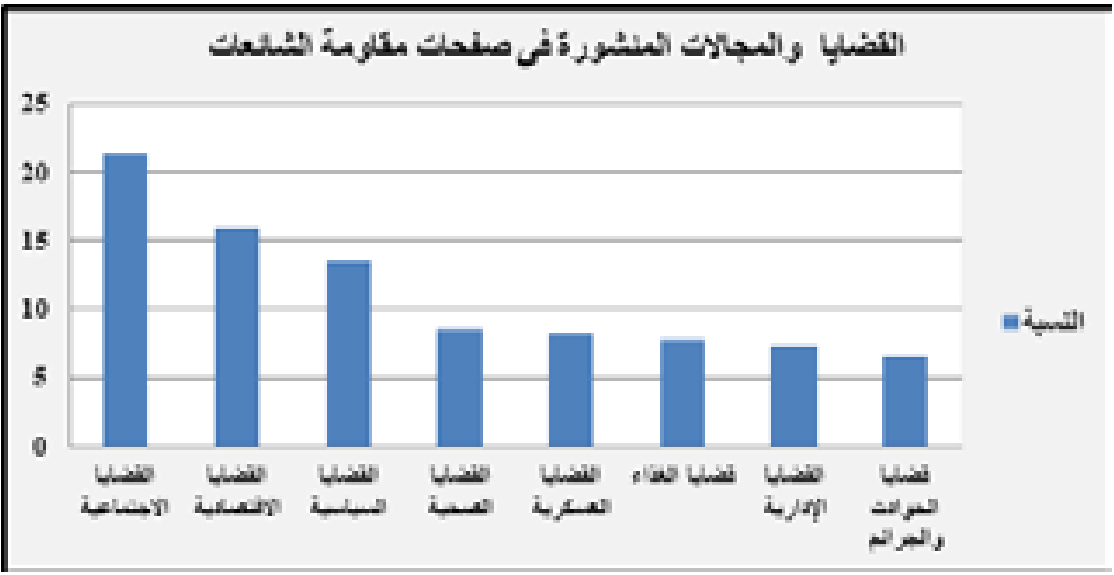

الشكل رقم (8): يوضح نسبة القضايا أو الجمالات المختلفة في صفحات

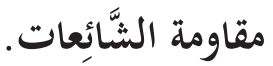

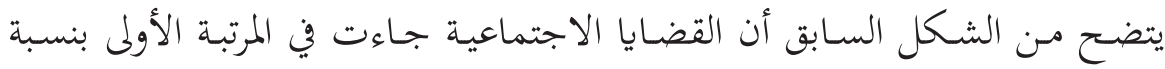

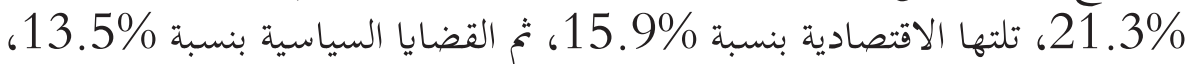
وذلك على مستوى جميع الصفحات الرسمية وغير الرسمية التي تم تحليلها. 


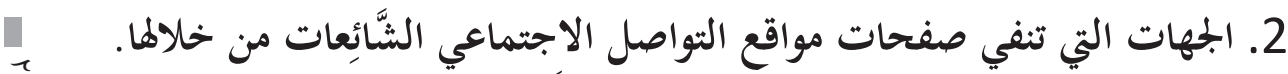

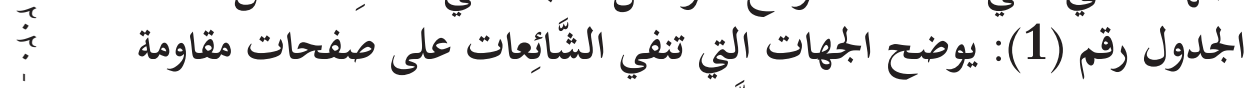

الشَّائعات

\begin{tabular}{|c|c|c|c|c|c|c|c|c|c|c|c|c|}
\hline \multicolumn{2}{|c|}{ الإجمالي } & \multicolumn{2}{|c|}{ أندية } & \multicolumn{2}{|c|}{ سيادية } & \multicolumn{2}{|c|}{ وهيئات } & \multicolumn{2}{|c|}{ لا توجد جهة } & \multicolumn{2}{|c|}{ وزارات } & \multirow{2}{*}{ 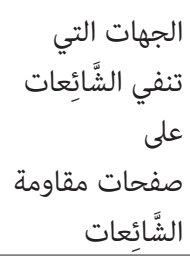 } \\
\hline$\%$ & ك5 & $\%$ & ك & $\%$ & ك & $\%$ & ك5 & $\%$ & ك) & $\%$ & ك) & \\
\hline 16.9 & 71 & 0 & 0 & 8.7 & 2 & 32.4 & 12 & 0 & 0 & 32 & 57 & صفحة مركز \\
\hline 41.5 & 175 & 0 & 0 & 34.7 & 8 & 27 & 10 & 57.4 & 97 & 33.7 & 60 & صفحة ده بجد \\
\hline 33.5 & 141 & 100 & 14 & 56.5 & 13 & 40.6 & 15 & 42.6 & 72 & 20.8 & 37 & صفحة متصدقش \\
\hline 5.7 & 24 & 0 & 0 & 0 & 0 & 0 & 0 & 0 & 0 & 13.5 & 24 & صفحة مجلس \\
\hline 100 & 421 & 100 & 14 & 100 & 23 & 100 & 37 & 100 & 169 & 100 & 178 & الإجمالي \\
\hline
\end{tabular}

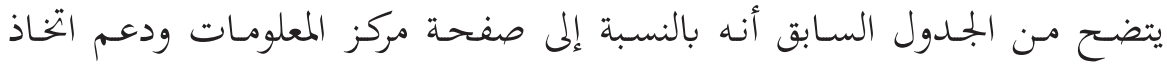

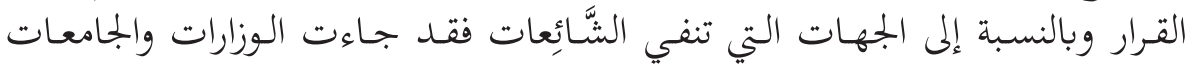

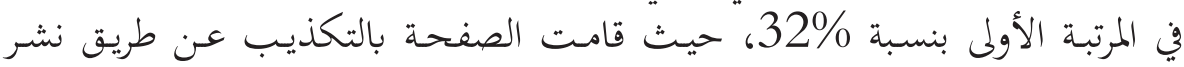

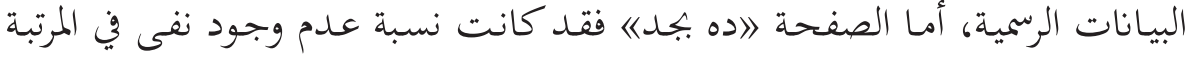

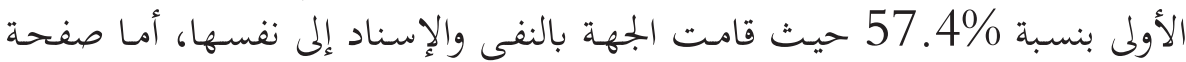

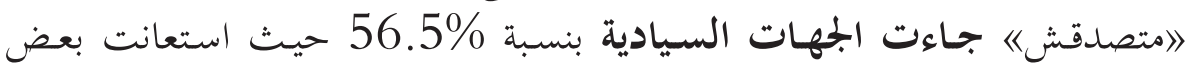

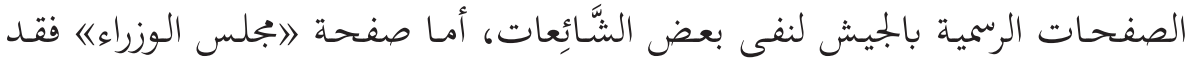

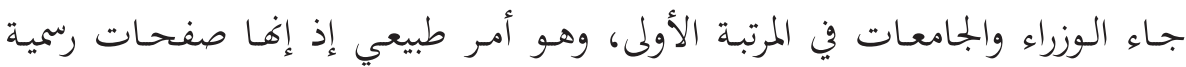

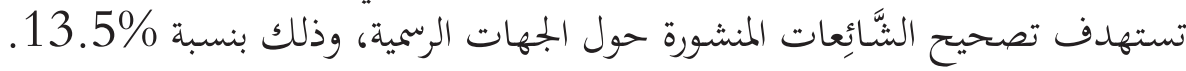


3. الأدلة والوقائع المستخدمة من قبل صفحات مواقع التواصل الاجتماعي لنفي

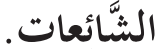

الجددول رقم (2): يوضح الأدلة المستخدمة في صفحات مقاومة الشَّائعِات.

\begin{tabular}{|c|c|c|c|c|c|c|c|c|c|c|}
\hline \multicolumn{2}{|c|}{ الإجمالي } & \multicolumn{2}{|c|}{ لا توجد أدلة } & \multicolumn{2}{|c|}{ صورة النفي } & \multicolumn{2}{|c|}{ صورة النفي } & \multicolumn{2}{|c|}{ رابط الخبر } & \multirow[t]{2}{*}{ أدلة مقاومة الشَّائعات } \\
\hline$\%$ & ك & $\%$ & ك & $\%$ & ك & $\%$ & ك & $\%$ & ك & \\
\hline 16.9 & 71 & 0 & 0 & 64.7 & 22 & 49.4 & 47 & 6.3 & 2 & صفحة مركز المعلومات \\
\hline 41.5 & 175 & 49.2 & 117 & 79.4 & 27 & 24.3 & 23 & 25 & 8 & صفحة ده بجد \\
\hline 33.5 & 141 & 50.8 & 121 & 20.5 & 7 & 1 & 1 & 68.7 & 22 & صفحة متصدقش \\
\hline 5.7 & 24 & 0 & 0 & 0 & 0 & 25.3 & 24 & 0 & 0 & صفحة مجلس الوزراء \\
\hline 100 & 421 & 100 & 238 & 100 & 34 & 100 & 95 & 100 & 32 & الإجمالي \\
\hline
\end{tabular}

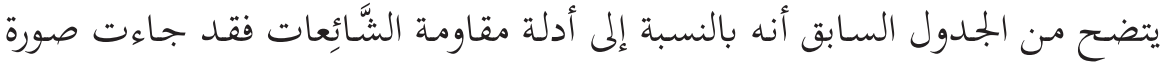

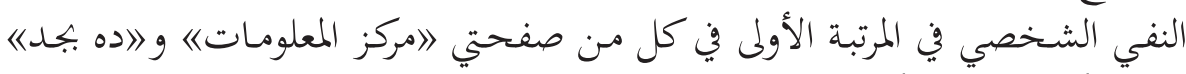

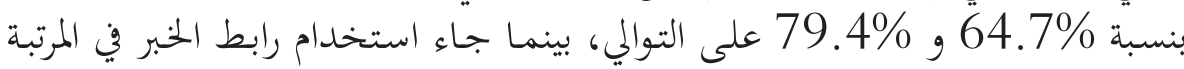

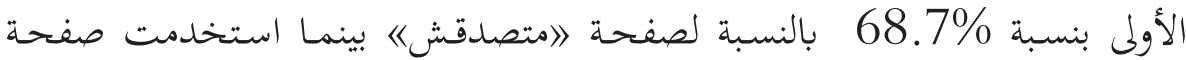

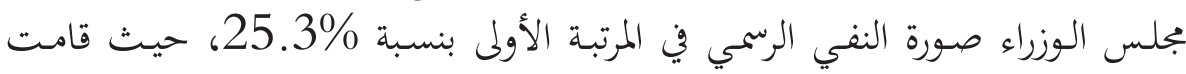

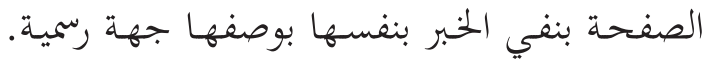
4. المصادر المستخدمة من قبل صفحات مقاومة الثَّائِعات لإثبات عدم صحة

الجلدول رقم (3): يوضح مصادر إثبات عدم صحة الشَّائعِة.

\begin{tabular}{|c|c|c|c|c|c|c|c|c|c|c|c|c|}
\hline \multicolumn{2}{|c|}{ الإجمالي } & \multicolumn{2}{|c|}{ وسائل الإعلام } & \multicolumn{2}{|c|}{ مواقع } & \multicolumn{2}{|c|}{ على التواصل مواقع } & \multicolumn{2}{|c|}{ نفسها } & \multicolumn{2}{|c|}{ بيان رسمي } & \multirow[t]{2}{*}{ صحة الشَّائعة إثبات عدم } \\
\hline$\%$ & s) & $\%$ & ك5 & $\%$ & ك5 & $\%$ & 5 & $\%$ & st & $\%$ & ك5 & \\
\hline 16.9 & 71 & 0 & 0 & 0 & 0 & 0 & 0 & 0 & 0 & 85.5 & 71 & صفحة مركز \\
\hline 41.5 & 175 & 83.3 & 20 & 27 & 16 & 52.2 & 48 & 37.5 & 61 & 12 & 10 & صفحة ده بجد \\
\hline 33.5 & 141 & 16.7 & 4 & 73 & 34 & 47.8 & 44 & 47.8 & 78 & 2.5 & 2 & صفحة متصدقش \\
\hline 5.7 & 24 & 0 & 0 & 0 & 0 & 0 & 0 & 14.7 & 24 & 0 & 0 & صفحة مجلس \\
\hline 100 & 421 & 100 & 24 & 100 & 59 & 100 & 92 & 100 & 163 & 100 & 83 & الإجمالي \\
\hline
\end{tabular}

يتضح من نتائج الجدول السابق أنه بالنسبة إلى مصادر إثبات عدم صحة الثَّائعة 


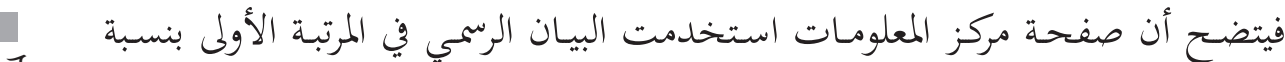

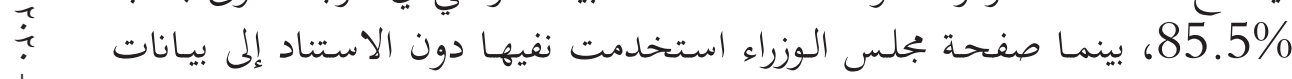

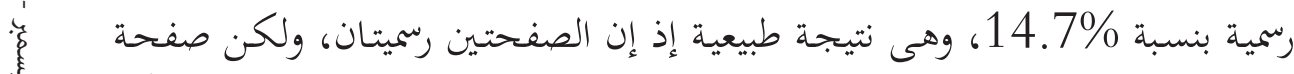

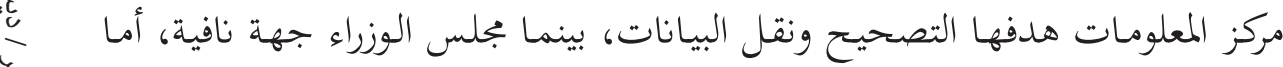

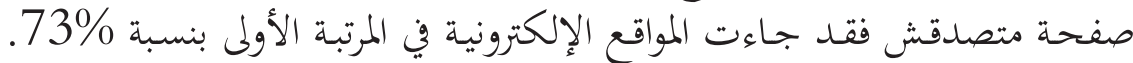
5. طرق نفي الثَّائعات المنشورة من خلاءل المَل صفحات مواقع الثواصل

الجحدول رقم (4): يوضح طرق نفي الشَّائعة

\begin{tabular}{|c|c|c|c|c|c|c|c|c|}
\hline \multicolumn{2}{|c|}{ الإجمالي } & \multicolumn{2}{|c|}{ لا يوجد نفى } & \multicolumn{2}{|c|}{ نفي جزئى } & \multicolumn{2}{|c|}{ نفي كامل } & \multirow{2}{*}{ طرقَّ نفي } \\
\hline$\%$ & ك & $\%$ & ك5 & $\%$ & ك & $\%$ & ك & \\
\hline 16.9 & 71 & 100 & 3 & 10.8 & 9 & 17.6 & 59 & صفحة مركز \\
\hline 41.5 & 175 & 0 & 0 & 56.7 & 47 & 38.2 & 128 & صفحة ده بجد \\
\hline 33.5 & 141 & 0 & 0 & 32.5 & 27 & 37 & 124 & صفحة متصدقش \\
\hline 5.7 & 24 & 0 & 0 & 0 & 0 & 7.2 & 24 & صفحة مجلس \\
\hline 100 & 421 & 100 & 3 & 100 & 83 & 100 & 335 & الإجمالي \\
\hline
\end{tabular}

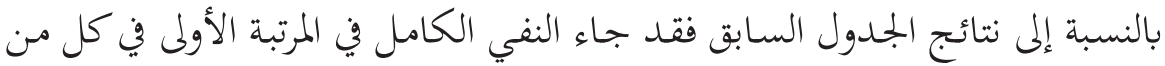

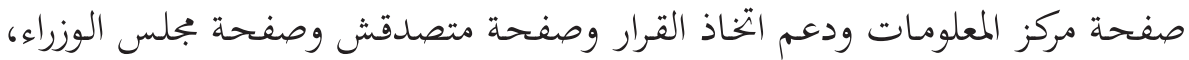

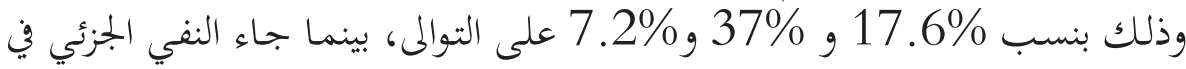

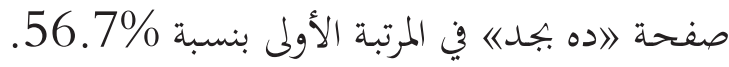

\section{ثانيًا: نتائج الدراسة الميدانية:}

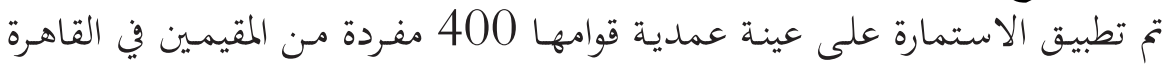

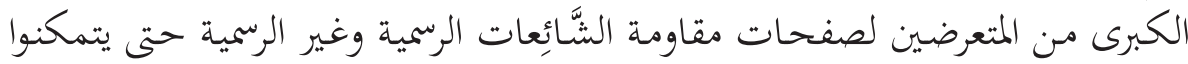
من مل ع الاستمارة. 
6. معدل استخدام موقع التواصل الاجتماعي 》فيسبوك) من قبل عينة الدراسة.

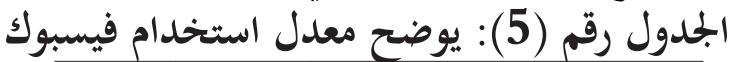

\begin{tabular}{|c|c|c|}
\hline$\%$ & ك & معدل استخدام فيسبوك \\
\hline 63 & 252 & دائًاً \\
\hline 21 & 84 & أحيانًا \\
\hline 16 & 64 & نادرًا \\
\hline 100 & 400 & الإجمالي \\
\hline
\end{tabular}

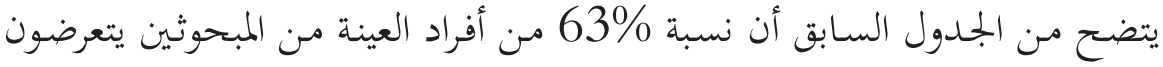

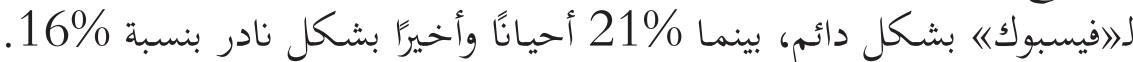

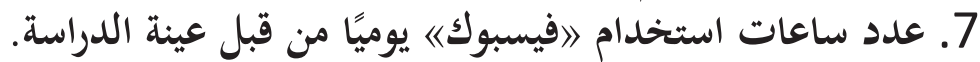

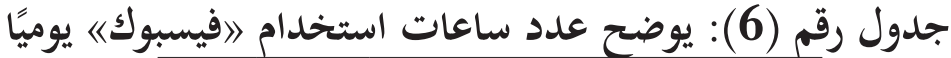

\begin{tabular}{|c|c|c|}
\hline$\%$ & ك & عدد ساعات استخدام "فيسبوك" يوميًا \\
\hline 33 & 132 & أكثر من ثلاث ساعات يوميًا \\
\hline 28 & 112 & من ساعتين إلى ثلاثة يوميًا \\
\hline 22 & 88 & من ساعة إلى أقل من ساعتين يوميًا \\
\hline 16 & 68 & أقل من ساعة \\
\hline 100 & 400 & الإجمالي \\
\hline
\end{tabular}

يتضح من الجدول السابق أن غالبية أفراد العينة من المبحوثين يحرصون على استخدام

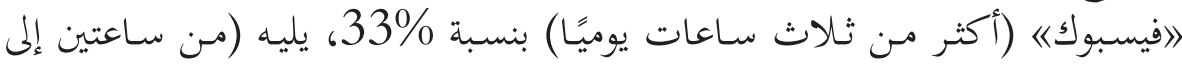

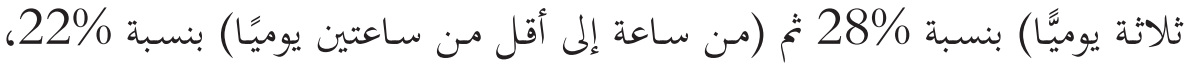

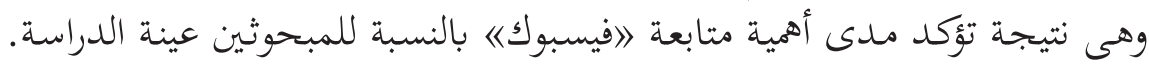

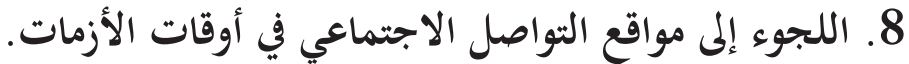

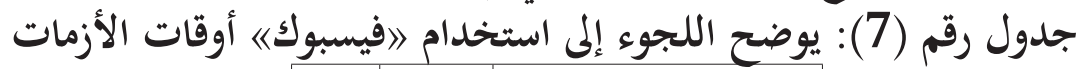

\begin{tabular}{|c|c|c|}
\hline$\%$ & ك5 & "فيسبوك《 ألجوء إلىتخدات الأزمات \\
\hline 52.8 & 211 & نعم \\
\hline 30 & 120 & إلى حد ما \\
\hline 17.3 & 69 & ע \\
\hline 100 & 400 & الإجمالي \\
\hline
\end{tabular}

يتضح من نتائج الجدول السابق أن إلن 52.8\% من أفراد العينة من المبحوثين 》ايلجئون

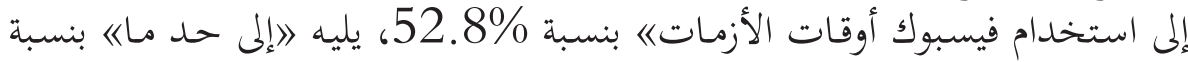




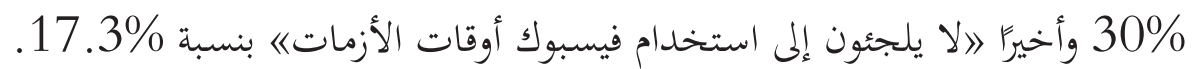

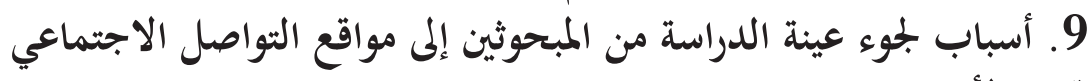

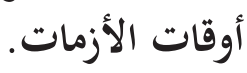

جدول رقم (8): يوضح أسباب اللجوء إلى صفحات مقاومة الشَّائعِات

\begin{tabular}{|c|c|c|}
\hline$\%$ & ك & أسباب اللجوء إلى صفحات مقاومة الشَّائعات \\
\hline 30.8 & 123 & لأنها تقوم بتوثيق المعلومة \\
\hline 27.2 & 109 & لسرعة نقلها الأخبار المتعلقة بمدى صحة الشَّائعة \\
\hline 21 & 84 & لتقليل التوتر الناتج عن التعرض للشائعات \\
\hline 12 & 48 & لأنها تعرض الجوانب المتعلقة بالشَّائِعات بحرية \\
\hline 9 & 36 & 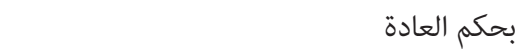 \\
\hline
\end{tabular}

*ن أكبر من 400 (اختيار أكثر من بديل).

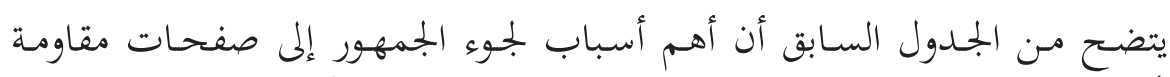

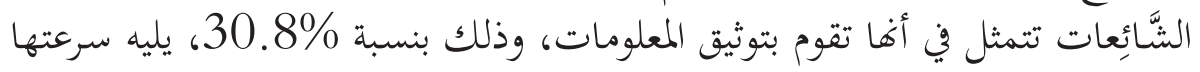

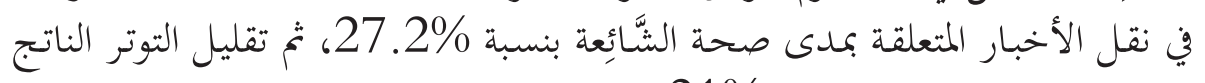

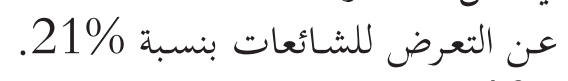

10. مدى اهتمام عينة الدراسة من المبحوثين بطريقة عرض نفي نفي الشَّائعِات.

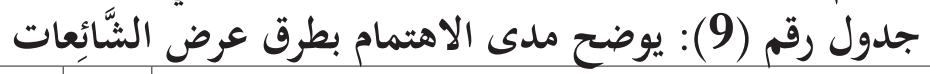

\begin{tabular}{|c|c|c|}
\hline$\%$ & ك & مدى الاهتهام بطرق عرض الشَّائعات \\
\hline 61 & 244 & ذات طابع جاد يمكن من خلاله التعرض للشائعة \\
\hline 39 & 156 & ذات طابع كوميدى ساخر لتقليل التوتر الناتج عن التعرض للشائعات \\
\hline 100 & 400 & الإجمالي \\
\hline
\end{tabular}

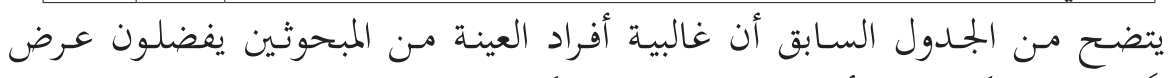

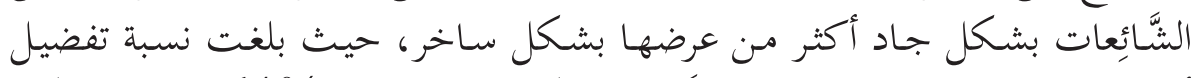

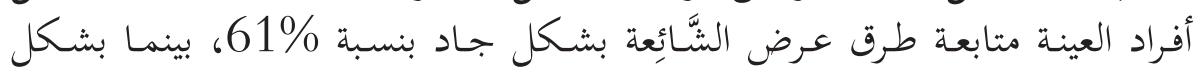
ساخر بنسبة 39\%. 


\section{1. متابعة عينة الدراسة من المبحوثين لصفحات مقاومة الشَّائعات الرسمية}

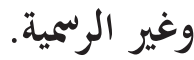

جدول رقم (10): مدى متابعة الصفحات الرسمية وغير الرسمية

\begin{tabular}{|c|c|c|c|c|c|c|c|c|}
\hline \multicolumn{2}{|c|}{ الإجمالي } & \multicolumn{2}{|c|}{ نادرًا } & \multicolumn{2}{|c|}{ أحيانًا } & \multicolumn{2}{|r|}{ دائًا } & \multirow[t]{2}{*}{ متابعة الصفحات الرسمية وغير الرسمية } \\
\hline$\%$ & ك & $\%$ & ك & $\%$ & ك5 & $\%$ & ك5 & \\
\hline 100 & 400 & 13 & 52 & 31 & 124 & 56 & 224 & ده بجد \\
\hline 100 & 400 & 18 & 72 & 24 & 96 & 58 & 232 & 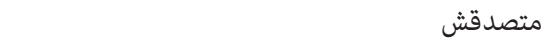 \\
\hline 100 & 400 & 9 & 36 & 33 & 132 & 58 & 232 & صفحة مجلس الوزراء \\
\hline 100 & 400 & 25 & 100 & 31 & 124 & 44 & 176 & الصفحة الرسمية لركز المعلومات ودعم اتخاذ القرار \\
\hline
\end{tabular}

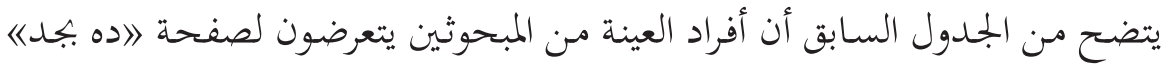

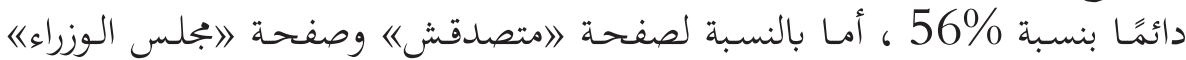

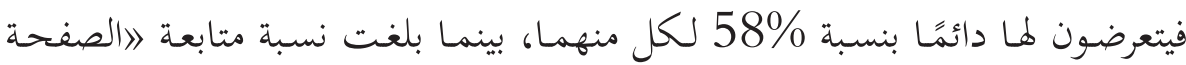

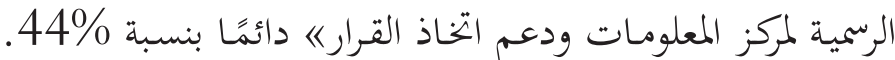

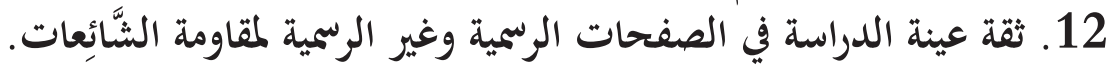

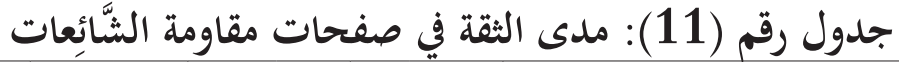

\begin{tabular}{|c|c|c|c|c|c|c|c|c|}
\hline \multicolumn{2}{|c|}{ 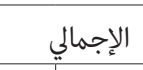 } & \multicolumn{2}{|r|}{ لا } & \multicolumn{2}{|c|}{ إلى حد ما } & \multicolumn{2}{|r|}{ 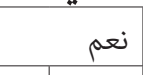 } & \multirow[t]{2}{*}{ مدى الثقة في صفحات مقاومة الشَّائعات } \\
\hline$\%$ & s) & $\%$ & ك & $\%$ & 5) & $\%$ & 5) & \\
\hline 100 & 400 & 7 & 28 & 44 & 176 & 49 & 196 & الصفحات الرسمية الخاصة بِقاومة الشَّائعات \\
\hline 100 & 400 & 15.8 & 63 & 47.3 & 189 & 37 & 148 & الصفحات غير الرسمية الخاصة بمقاومة الشَّائعات \\
\hline
\end{tabular}

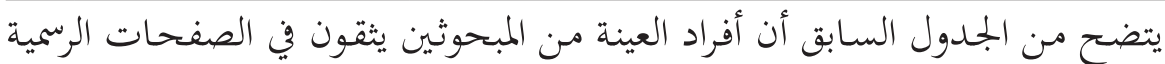

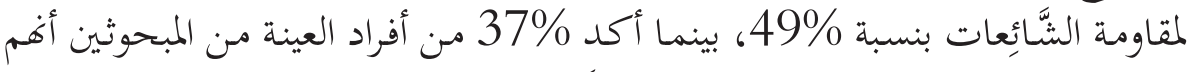

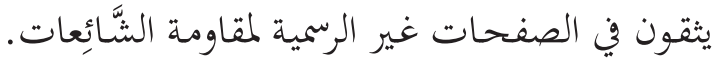


13. اتجاه عينة الدراسة من المبحوثين نحو الدور الذي تلعبه صفحات مقاومة

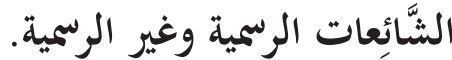

جدول رقم (12): الاتجاه نحو صفحات مقاومة الشَّائعات

\begin{tabular}{|c|c|c|c|c|c|c|c|}
\hline الوزن & \multicolumn{6}{|c|}{ درجة الموافقة } & \multirow[t]{2}{*}{ الاتجاه: } \\
\hline & \multicolumn{2}{|c|}{ غير موافق } & \multicolumn{2}{|c|}{ موافق إلى مد ما } & \multicolumn{2}{|c|}{ كوافق إلى حد } & \\
\hline & $\%$ & 5) & $\%$ & ك & $\%$ & ك & \\
\hline 79.66 & 7 & 28 & 47 & 188 & 46 & 184 & 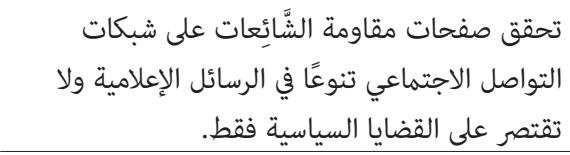 \\
\hline 76 & 9 & 36 & 54 & 216 & 37 & 148 & تقدم تلك الصفحات كل ما يمت بصلة للشائعات \\
\hline 66.66 & 27 & 108 & 46 & 184 & 27 & 108 & عشكل غير متوازن. تلك الصفحات المعلومات الخاصة بالشَّائعات \\
\hline 68.33 & 29 & 116 & 37 & 148 & 34 & 136 & تصمالح النظام السياسي. مفاومة الشَّائعات تزييف المعلومات \\
\hline 64 & 35 & 140 & 38 & 152 & 27 & 108 & تروجَّائَ تلكات. الصفحات لوجهات النظر الحكومية نحو \\
\hline 72.66 & 16 & 64 & 50 & 200 & 34 & 36 & تلمببت تلك الصفحات في خلق أزمة ثقة ومصداقية \\
\hline 66.66 & 32 & 128 & 36 & 144 & 32 & 128 & تبنت تلك الصفحات وجهات نظر مؤيدة للنظام \\
\hline 69 & 24 & 96 & 45 & 180 & 31 & 124 & 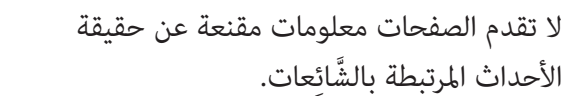 \\
\hline
\end{tabular}

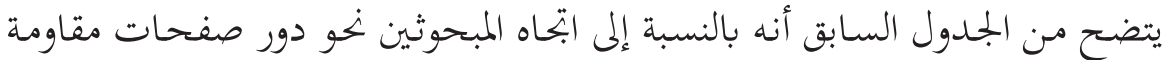

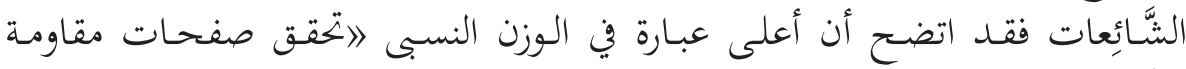

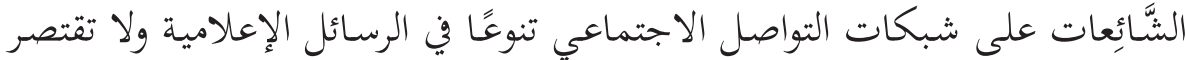

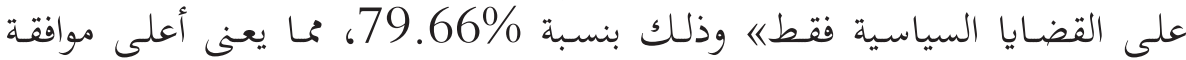

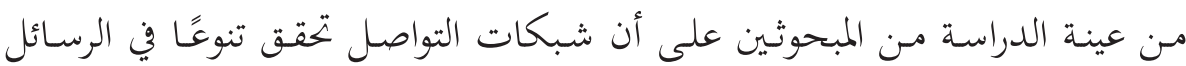

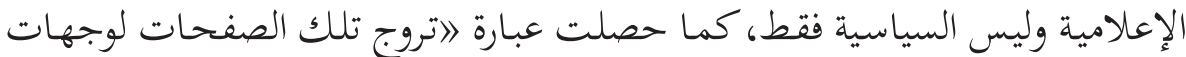

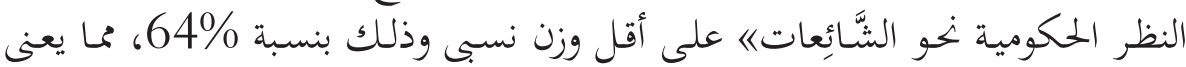

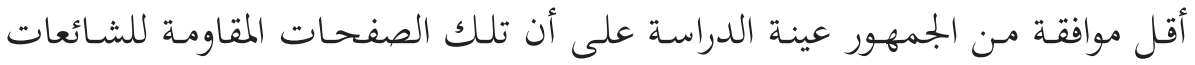


تروج لوجهة نظر حكومية، وهو مـا يعني ثقـة أفراد العينة في تلك الصفحات.

14. الدور الذي تلعبه صفحات مقاومة الشَّائعات الرسمية وغير الرسمية من وجهة نظر عينة الدراسة من المبحوثين.

جدول رقم (13): الاتجاه نحو صفحات اللئة مقاومة الشَّائعات

\begin{tabular}{|c|c|c|c|c|c|c|c|}
\hline \multicolumn{7}{|c|}{ الاتجاه نحو العبارة } & \multirow[t]{3}{*}{ الاتجاه } \\
\hline \multirow{2}{*}{ 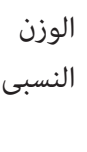 } & \multicolumn{2}{|c|}{ غير موافق } & \multicolumn{2}{|c|}{ موافق إلى ما ما } & \multicolumn{2}{|c|}{ مد كوافق إلى } & \\
\hline & $\%$ & ك & $\%$ & 5) & $\%$ & 5) & \\
\hline 76.66 & 16 & 64 & 38 & 152 & 64 & 184 & ساهمت هذه المواقع في تكوين رؤية موضوعية \\
\hline 75 & 12 & 48 & 50 & 200 & 37 & 148 & 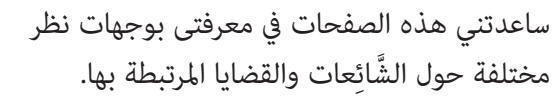 \\
\hline 79.33 & 14 & 56 & 34 & 136 & 52 & 208 & جعلتني اهتم بمعرفة تعامل الحكومة مع بعض الأحداث \\
\hline 66 & 33 & 132 & 36 & 144 & 31 & 124 & جعلتني أعارض ممارسات الحكومة نحو الشَّائعات. \\
\hline 68.33 & 23 & 92 & 48 & 192 & 29 & 116 & أصبحت لدى ثقة في الحكومة وتوجهاتها. \\
\hline 70.66 & 26 & 104 & 36 & 144 & 38 & 152 & أقنَّعتني أن جماعة الإخوان المسلمين وراء تلك \\
\hline 68.33 & 23 & 92 & 49 & 196 & 28 & 112 & جعلتنى اقتنَع بأن المعارضة هى السبب وراء تفاقم \\
\hline 79 & 12 & 48 & 39 & 156 & 49 & 196 & 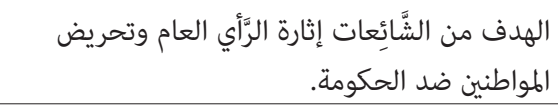 \\
\hline 75 & 21 & 84 & 33 & 132 & 46 & 184 & الهدف من الشَّائعات التأكيد على أن مصر دولة لأل تراعى مصالح المواطن المصري. \\
\hline 79 & 19 & 76 & 25 & 100 & 56 & 224 & 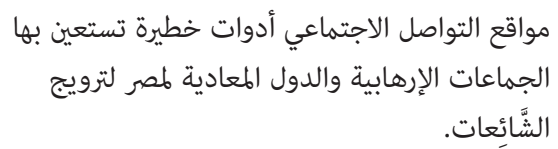 \\
\hline
\end{tabular}

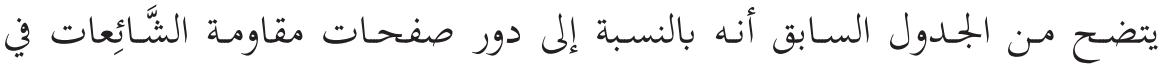

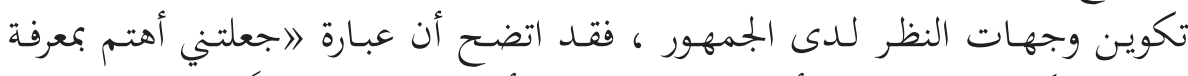

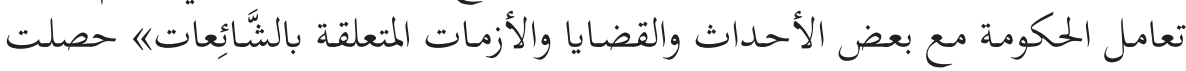

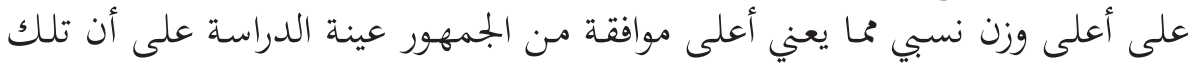

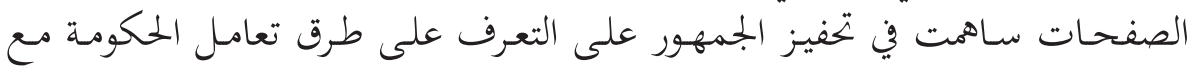


الأزمات، وذك بوزن نسبي 79.33، بينما حصلت عبارة اجعلتنى أعارض منارسات

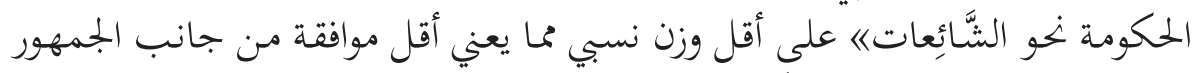

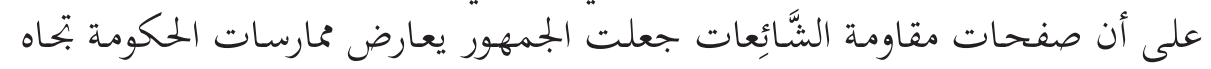

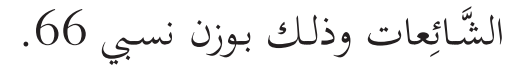

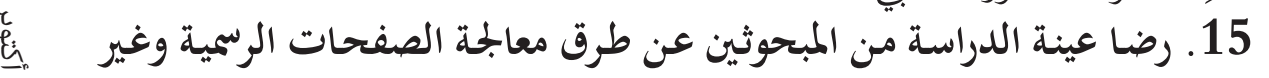

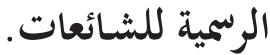

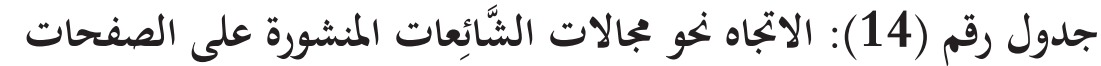

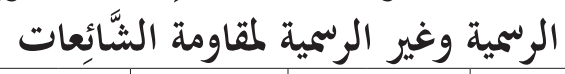

\begin{tabular}{|c|c|c|c|c|c|c|c|}
\hline \multirow{2}{*}{ النسبي } & \multicolumn{2}{|c|}{ غير راضٍ } & \multicolumn{2}{|c|}{ إلى حدٍ ما } & \multicolumn{2}{|c|}{ راضٍ قمامًا } & \multirow[t]{2}{*}{ الشَّائعِات } \\
\hline & $\%$ & ك & $\%$ & ك & $\%$ & ك) & \\
\hline 73 & 16 & 64 & 49 & 196 & 35 & 140 & شائعات رياضية \\
\hline 66.66 & 32 & 128 & 36 & 144 & 32 & 128 & شائعات سياسية \\
\hline 71.66 & 17 & 68 & 51 & 204 & 32 & 128 & شائعات مجتمعية \\
\hline 68.66 & 23 & 92 & 48 & 192 & 29 & 116 & شائعات تعليمية \\
\hline 67.66 & 24 & 96 & 49 & 196 & 27 & 108 & شائعات اقتصادية \\
\hline
\end{tabular}

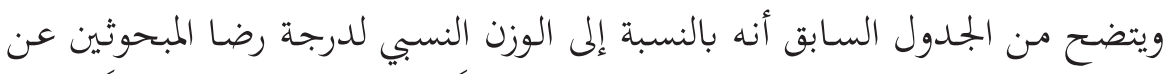

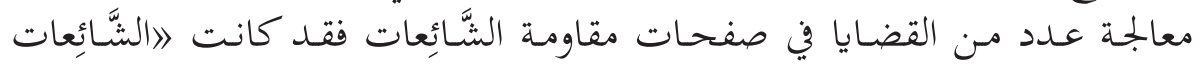

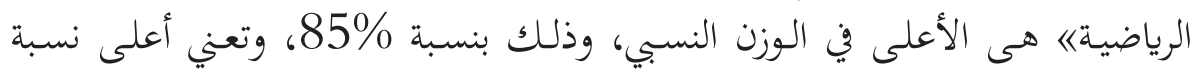

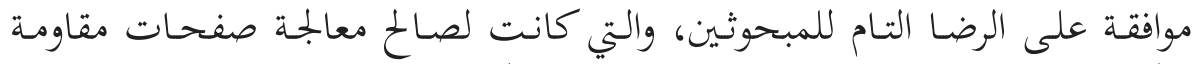

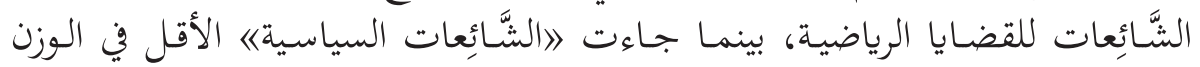

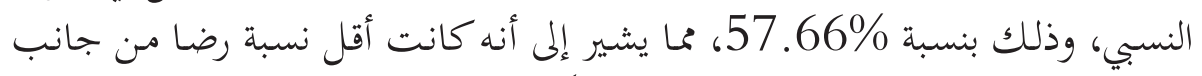

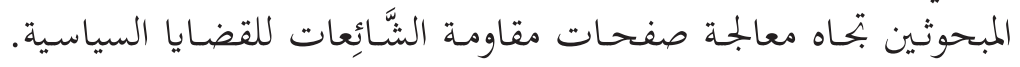

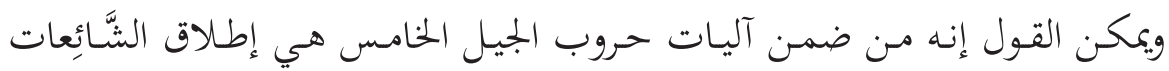

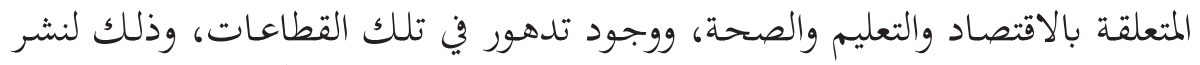

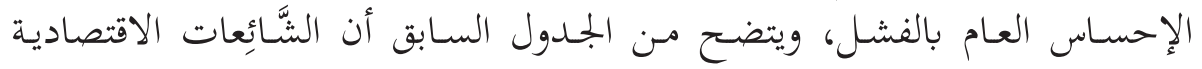

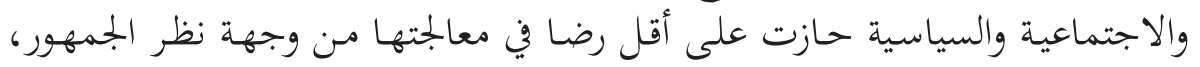

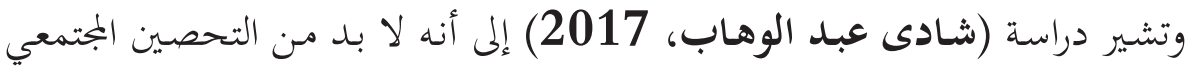

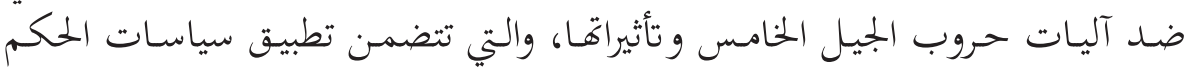




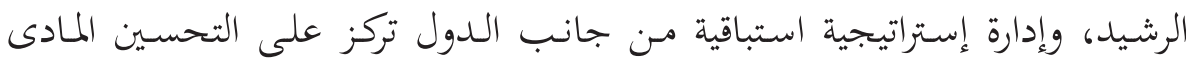

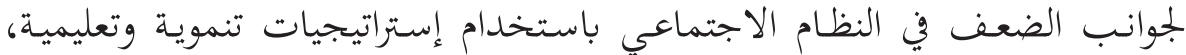

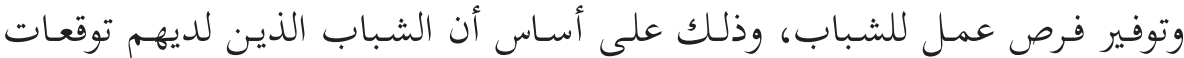

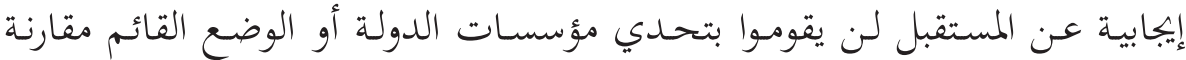

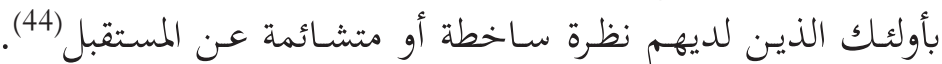

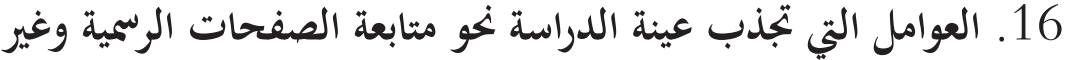
الرسمية لمقاومة الشَّائعات. جدول رقم (15): العوامل التي تجذب الجمهورو لمتابعة صفحات مقاومة التمات

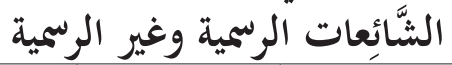

\begin{tabular}{|c|c|c|c|c|c|c|c|}
\hline \multirow[t]{2}{*}{ النسبي } & \multicolumn{2}{|c|}{ غوافق } & \multicolumn{2}{|c|}{ إلى حدٍ ما } & \multicolumn{2}{|c|}{ موافق إلى حدٍ } & \multirow{2}{*}{ الرتابعة صفحات مقاومة الشَّائعات الرسمية وغير } \\
\hline & $\%$ & ك) & $\%$ & ك) & $\%$ & ك & \\
\hline 85 & 7 & 28 & 31 & 124 & 62 & 248 & الصور أو الفيديوهات \\
\hline 83 & 6 & 24 & 39 & 156 & 55 & 220 & تحليل وتفسير الجوانب المختلفة للقضية \\
\hline 75.66 & 17 & 68 & 39 & 156 & 44 & 176 & الوثائق والطستندات \\
\hline 78 & 6 & 24 & 54 & 216 & 40 & 160 & مصادر المعلومات المستخدمة داخل المنشور \\
\hline 71 & 8 & 32 & 53 & 212 & 39 & 156 & الأرقام والإحصاءات \\
\hline
\end{tabular}
*ن=ن الأنقام

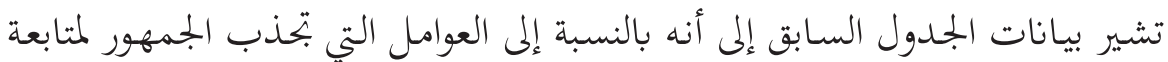

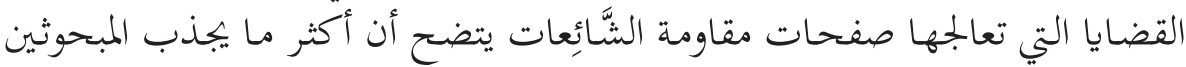

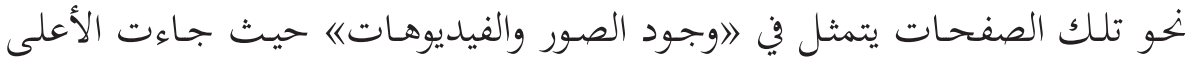

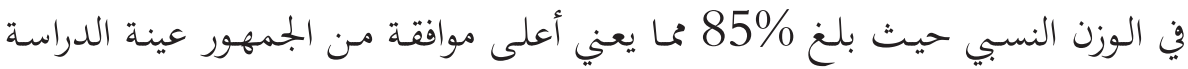

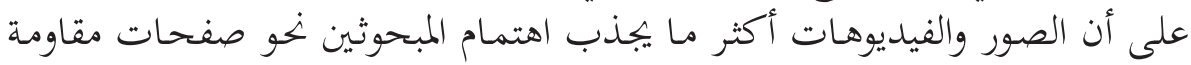
الشَّائعات. آن الصون 


\section{7. العوامل التي تؤدي إلى ظهور الشَّائعات من وجهة نظر الجمههور عينة}

الدراسة.

جدول رقم (16): أسباب ظهور وانتشار الشَّائعات عبر مواقع التواصل

\begin{tabular}{|c|c|c|}
\hline$\%$ & ك & أسباب ظهور وانتشار الشَّائعات عبر مواقع التواصل الاجتماعي \\
\hline 82 & 328 & صمت الإعلام التقليدى عن إظهار الحقائق. \\
\hline 65 & 260 & الاستخدام الخاطئ لوسائل التواصل الاجتماعي. \\
\hline 61 & 244 & عدم وجود رقابة لتفنيد الشَّائعات و إثبات عكسها. \\
\hline 61 & 244 & إعادة نشر المعلومات والأخبار الخاطئة من باب التسلية. \\
\hline 57 & 228 & عدم التوعية بدور المتحدث الرسمي باسم الوزارات وعدم معرفة بعض الأفراد بوجوده. \\
\hline
\end{tabular}

*ن أكبر من 400 (اختيار أكثر من بديل).

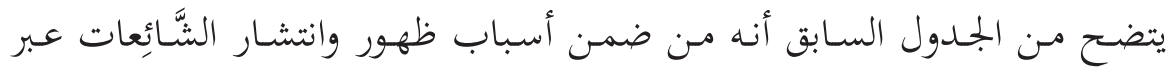

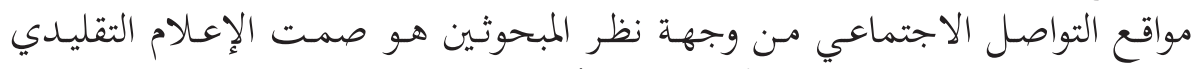

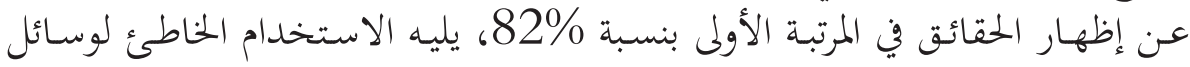

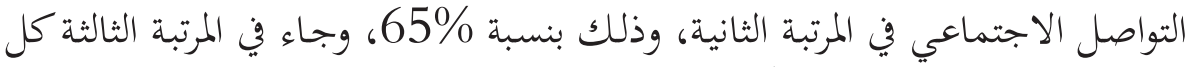

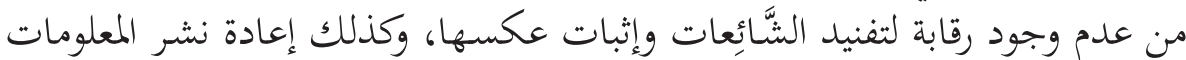

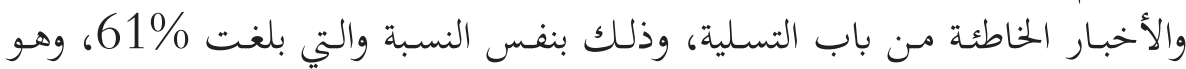

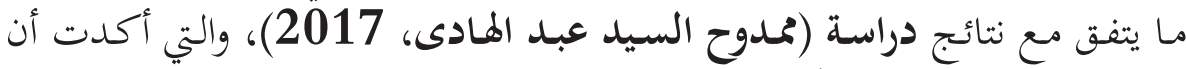

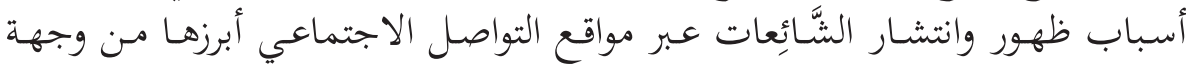

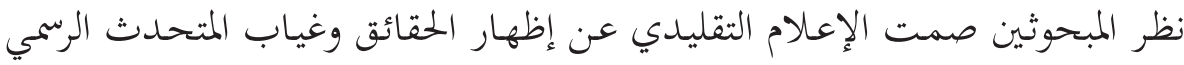

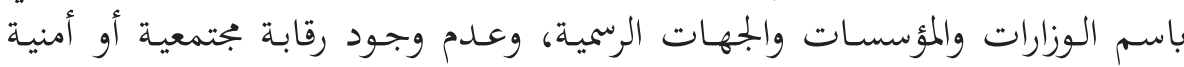
خاصة على مواقع التواصل الاجتماعي. 
18. وجهة نظر عينـة الدراسـة نحو كيفيـة التصـدي للشـائعات المنشـورة عبر

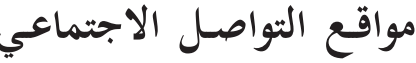

جدول رقم (17): كيفية التصدي لظهور وانتشار الشَّائعات عبر مواقع إِع

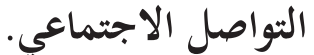

\begin{tabular}{|c|c|c|}
\hline$\%$ & ك & التصدي لظهور وانتشار الشَّائِعات عبر مواقع التواصل الاجتماعي \\
\hline 80 & 320 & التأكد من صحة الأخبار والمعلومات الواردة وعدم نشر أي معلومة دون التأكد منها. \\
\hline 73 & 292 & محاسبة الصفحات التي تروج شائعات بهدف الإضرار بالأمن العام أو إثارة البلبلة. \\
\hline 67 & 266 & ضرورة رد الجهات الرسمية على الشَّائعات المنشورة بسرعة. \\
\hline 65 & 260 & وضع تشريعات وقوانين لكافحة ترويج الشَّائعات. \\
\hline 63 & 252 & استخدام وسائل حديثة لرصد وتتبع منتجي ومصادر الشَّائعات. \\
\hline 59.8 & 239 & فرض رقابة على استخدام وسائل التواصل الاجتماعي. \\
\hline
\end{tabular}

*ن أكبر من 400 (اختيار أكثر من بديل).

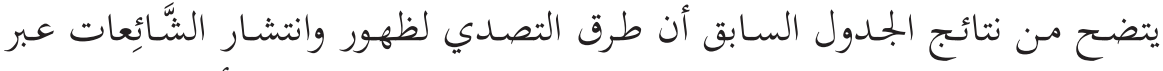

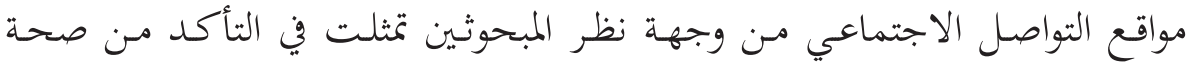

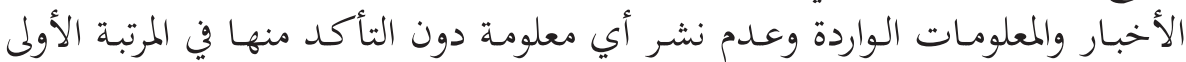

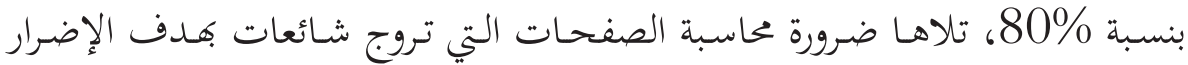

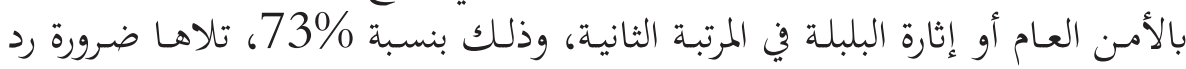

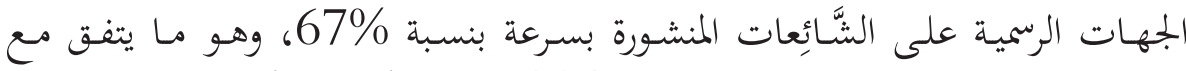

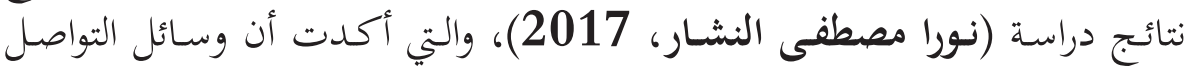

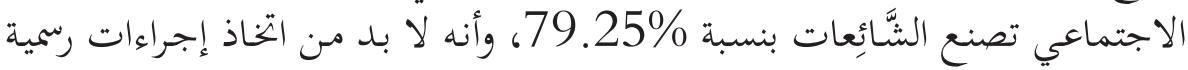

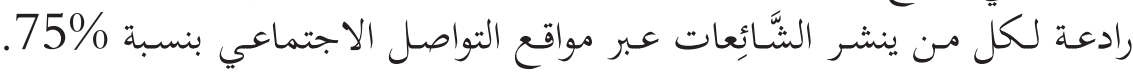


19. العوامل التي تؤدي إلى زيادة انتشار الشَّائعات من وجهة نظر عينة

جدول رقم (18): العوامل التي تؤثر على انتشار الثَّائعات.

\begin{tabular}{|c|c|c|c|c|c|c|c|}
\hline \multirow[t]{2}{*}{ 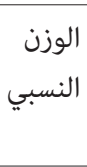 } & \multicolumn{2}{|c|}{ 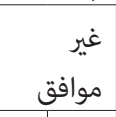 } & \multicolumn{2}{|c|}{ إلى حدٍ ما } & \multicolumn{2}{|c|}{ مدافٍ كبير إلى } & \multirow[t]{2}{*}{ العوامل التي تؤثر على انتشار الشَّائعات } \\
\hline & $\%$ & ك & $\%$ & ك & $\%$ & ك & \\
\hline 84 & 7 & 28 & 24 & 96 & 69 & 276 & عدم وجود قوانين لردع مروجي الشَّائعات. \\
\hline 87.33 & 8 & 32 & 23 & 92 & 69 & 276 & سهولة تأثر مستخدمي الشبكات بالشَّائعات المنتشرة. \\
\hline 87 & 13 & 52 & 19 & 76 & 68 & 272 & الشَّائعاتلة إنتاج المعلومات ونشرها زاد من سرعة انتشار \\
\hline 83.66 & 13 & 52 & 20 & 80 & 76 & 268 & غياب الشفافية وتأخر التصريحات الرسمية. \\
\hline 84.66 & 11 & 44 & 26 & 104 & 63 & 252 & عدم وجود ما يكفل حرية تداول المعلومات. \\
\hline 85 & 10 & 40 & 29 & 116 & 61 & 244 & غياب الوعي بخطورة الشَّائعات. \\
\hline 83.66 & 10 & 40 & 29 & 116 & 61 & 244 & الأمنية والمجتمعيات شبكات التواصل الاجتماعي غير خاضعة للرقابة \\
\hline 83.33 & 11 & 44 & 28 & 112 & 61 & 244 & شخصيات. إنشاء مواقع مزيفة بأسماء جهات رسمية وغير رسمية أو \\
\hline 82.33 & 11 & 44 & 31 & 124 & 58 & 232 & الاجتماعية التحرى عن مروجي الشَّائعات عبر مواقع التواصل \\
\hline
\end{tabular}

$.400=$ نे $^{*}$

تشير بيانات الجمدول السابق إلى أنه بالنسبة إلى العوامل التي تؤثر على انتشار إنتار

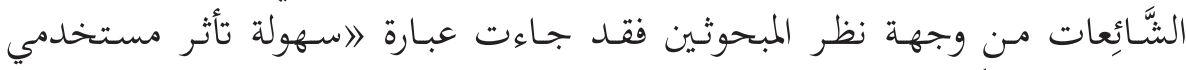

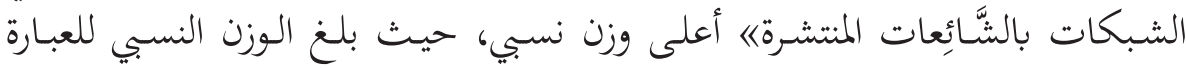

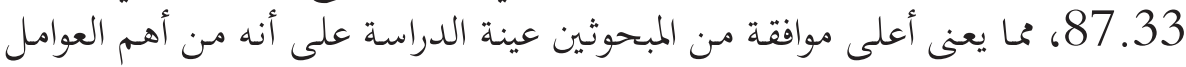

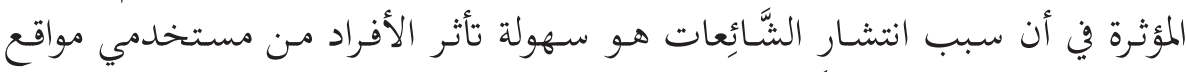

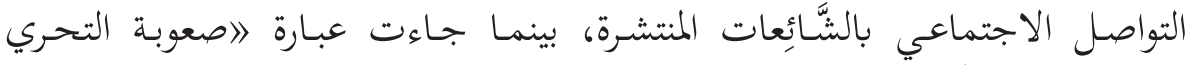

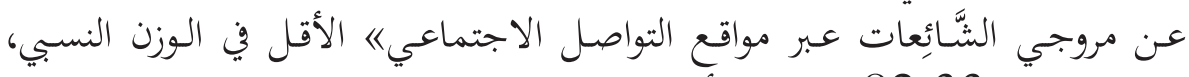

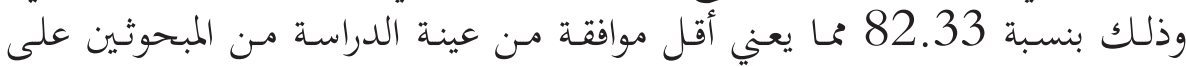

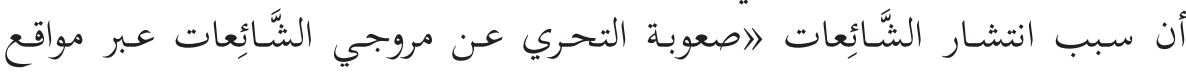

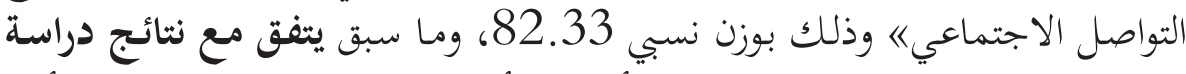
(Abdullah Rashad, 2016) 
السياسي تتجه بعض الحلكومات والمعارضون أيضًا لتلك الحكومات والأحزاب

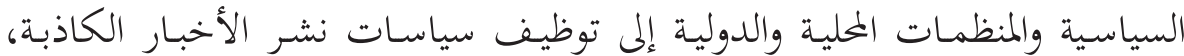

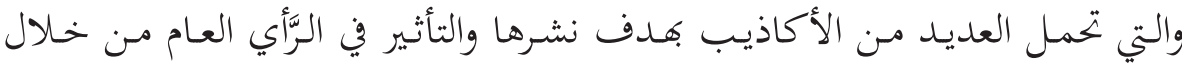

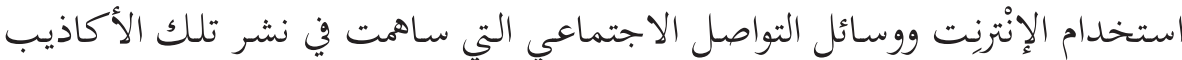

$$
\text { والشَّائعات (54). }
$$

\section{0. الفئات التي تستهدفها الثَّائعات من وجهة نظر عينة الدراسة}

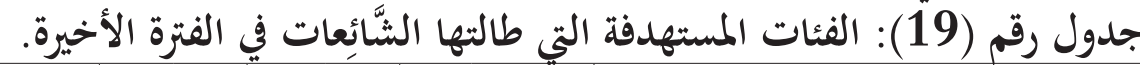

\begin{tabular}{|c|c|c|c|c|c|c|c|}
\hline \multirow{3}{*}{ الوزن } & \multirow{2}{*}{\multicolumn{2}{|c|}{ 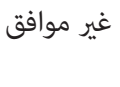 }} & \multicolumn{2}{|c|}{ إلى حدٍ ما } & \multirow{2}{*}{\multicolumn{2}{|c|}{ كبير }} & \multirow[t]{3}{*}{ الفئات التي طالتها الشَّائعات في الفترة الأخيرة: } \\
\hline & & & & & & & \\
\hline & $\%$ & ك & $\%$ & ك) & $\%$ & ك & \\
\hline 88 & 6 & 24 & 24 & 96 & 70 & 280 & رئيس الجمهورية \\
\hline 95 & 2 & 8 & 41 & 164 & 57 & 228 & الشخصيات السياسية \\
\hline 80 & 17 & 68 & 26 & 104 & 57 & 228 & الفنانون \\
\hline 75.33 & 14 & 56 & 33 & 132 & 53 & 212 & مسئولون حكوميون \\
\hline 79.66 & 13 & 52 & 35 & 140 & 52 & 208 & الرياضيون \\
\hline 74.66 & 16 & 64 & 33 & 132 & 51 & 204 & إعلاميون \\
\hline 72 & 17 & 68 & 40 & 160 & 43 & 172 & رجال الأعمال \\
\hline 78.33 & 19 & 76 & 38 & 152 & 43 & 172 & دول عربية \\
\hline 79.33 & 23 & 92 & 38 & 152 & 39 & 156 & أعضاء محلس الشعب \\
\hline
\end{tabular}

تشير بيانات الجمدول السابق إلى أنه بالنسبة إلى الفئات المستهدفة التي طالتها

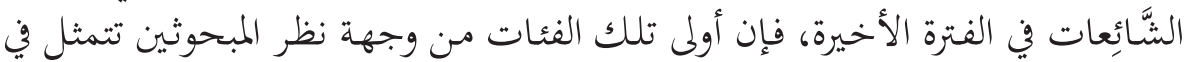

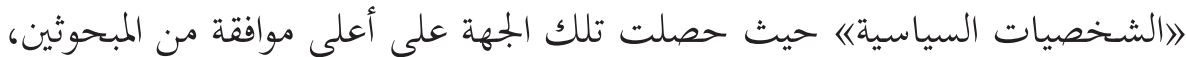

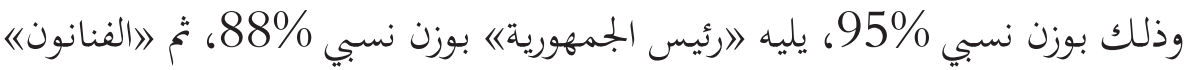

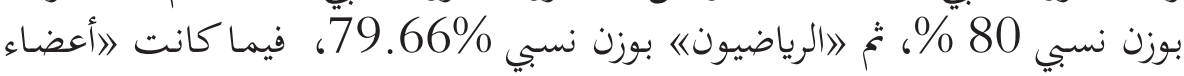

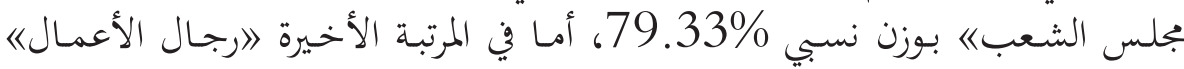
بوزن نسبي 
الجدول رقم (20): يوضح القضايا أو الجمالات التي تناولتها صفحات

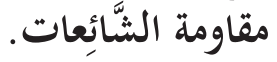

\begin{tabular}{|c|c|c|c|c|c|c|c|c|c|c|c|c|c|c|c|c|c|c|c|c|c|c|}
\hline \multicolumn{2}{|c|}{ الإجمالي } & \multicolumn{2}{|c|}{ قالحوادثا } & \multicolumn{2}{|c|}{ الإداريةً } & \multicolumn{2}{|c|}{ قالذايا } & \multicolumn{2}{|c|}{ قضضيا } & \multicolumn{2}{|c|}{ الرياضية } & \multicolumn{2}{|c|}{ الصحيةً } & \multicolumn{2}{|c|}{ الاقتصادية القضايا } & \multicolumn{2}{|c|}{ الاجتماعية } & \multicolumn{2}{|c|}{ العكرية } & \multicolumn{2}{|c|}{ السياسيةيا } & \multirow{2}{*}{ التناولتئات التصات } \\
\hline$\%$ & $s$ & $\%$ & $s$ & $\%$ & s & $\%$ & s & $\%$ & $s$ & $\%$ & $s$ & $\%$ & $s$ & $\%$ & s & $\%$ & $s$ & $\%$ & $s$ & $\%$ & s & \\
\hline 16.9 & 71 & 0 & 0 & 25.8 & 8 & 21 & 9 & 20 & 5 & 0 & 0 & 26 & 8 & 20.9 & 14 & 28.9 & 26 & 0 & 0 & 2 & 1 & المعلومزت \\
\hline 41.5 & 175 & 25 & 7 & 25.8 & 8 & 60.5 & 26 & 32 & 8 & 65.5 & 19 & 16 & 5 & 46.3 & 31 & 28.9 & 26 & 48 & 12 & 63.5 & 33 & صفحة ده \\
\hline 33.5 & 141 & 75 & 21 & 0 & 0 & 18.5 & 8 & 44 & 11 & 34.5 & 10 & 42 & 13 & 31.3 & 21 & 40 & 36 & 52 & 13 & 34.6 & 18 & متصدقشة \\
\hline 5.7 & 24 & 0 & 0 & 48.4 & 15 & 0 & 0 & 4 & 1 & 0 & 0 & 16 & 5 & 1.5 & 1 & 2.2 & 2 & 0 & 0 & 0 & 0 & الوزرلس \\
\hline 100 & 421 & 100 & 28 & 100 & 31 & 100 & 43 & 100 & 25 & 100 & 29 & 100 & 31 & 100 & 67 & 100 & 90 & 100 & 25 & 100 & 52 & الإجمالي \\
\hline
\end{tabular}

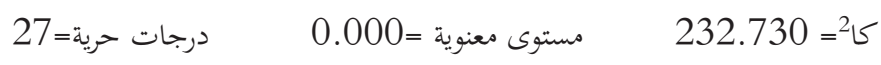

من الجمدول السابق يتضح وجـود علاقة دالة إحصائيًا بين القضايا أو الموضوعات

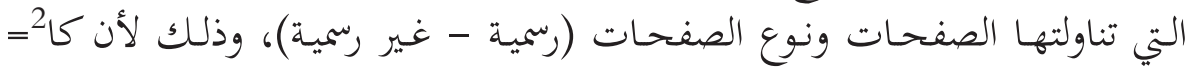
232.730

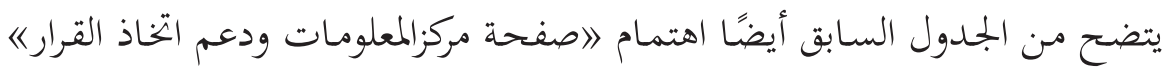

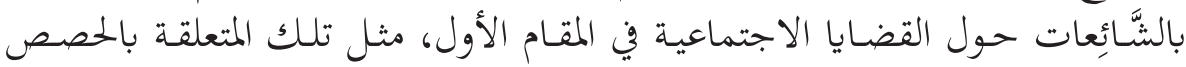

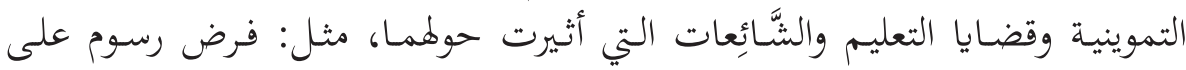

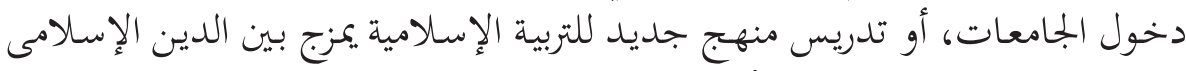

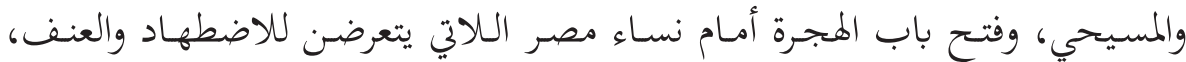

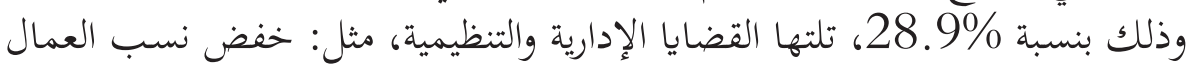

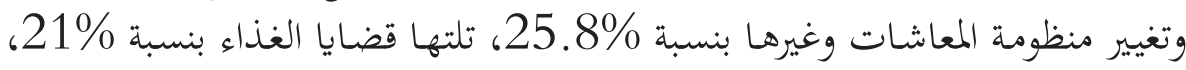

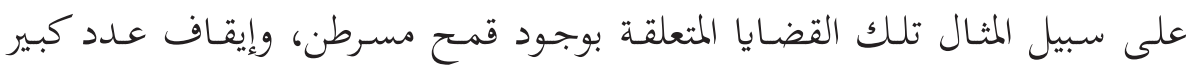




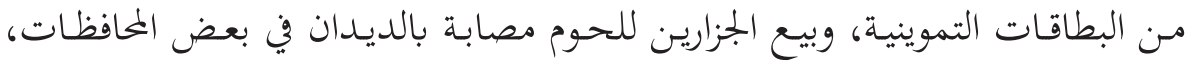

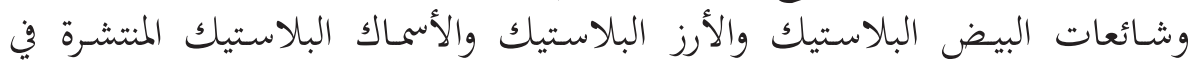
الأسـواق.

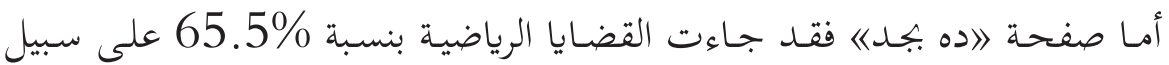

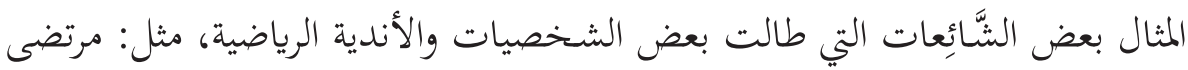

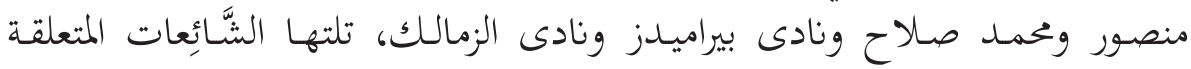

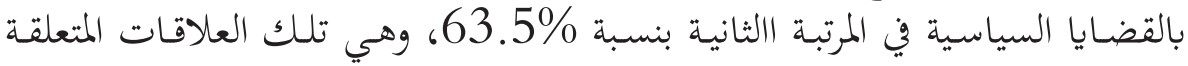

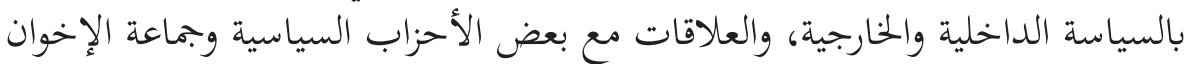

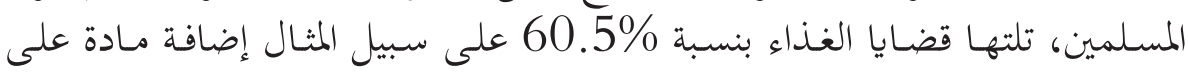

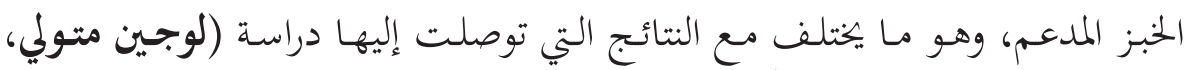

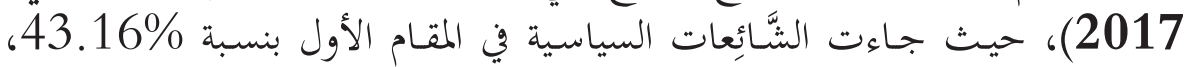

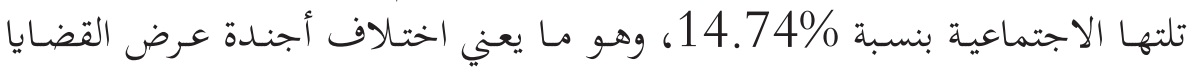

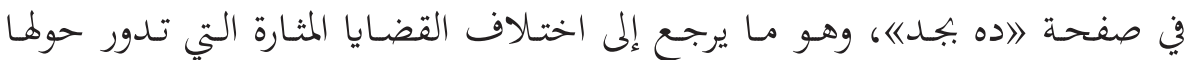

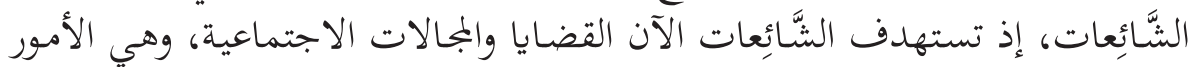

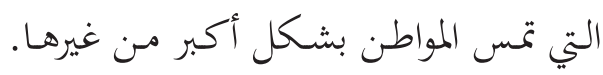

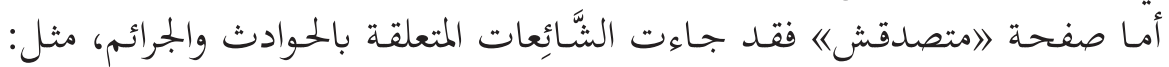

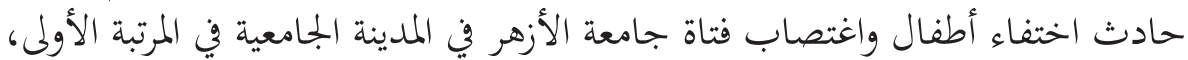

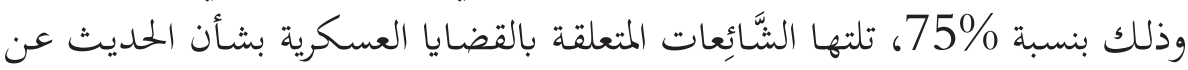

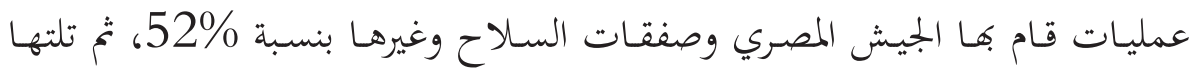

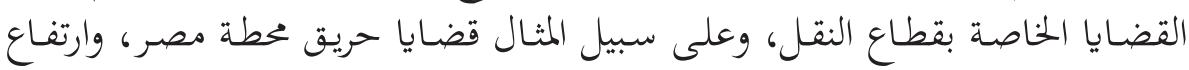

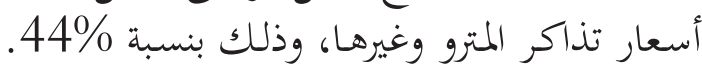

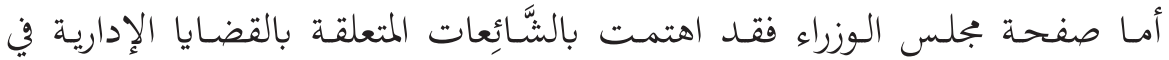

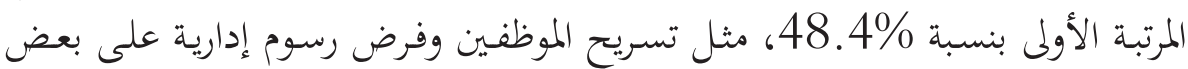

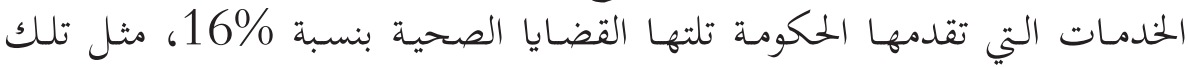

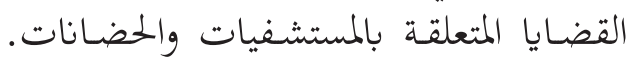




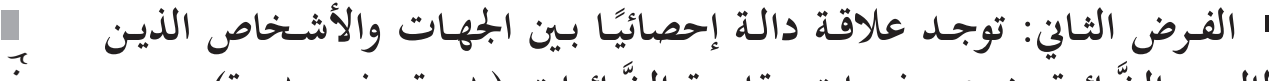

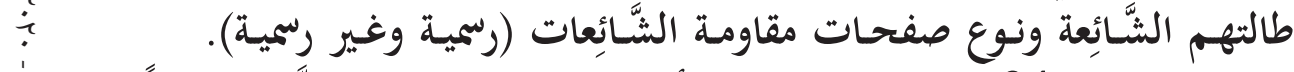

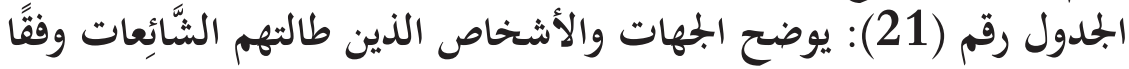
للصفحات عينة الدراسة.

\begin{tabular}{|c|c|c|c|c|c|c|c|c|c|c|c|c|c|c|c|c|c|c|c|c|c|c|}
\hline \multicolumn{2}{|c|}{ الإجمالي } & \multicolumn{2}{|c|}{ قالحوادث } & \multicolumn{2}{|c|}{ الإداريةيا } & \multicolumn{2}{|c|}{ قضذايا } & \multicolumn{2}{|c|}{ قضايل } & \multicolumn{2}{|c|}{ الرياضضية } & \multicolumn{2}{|c|}{ الصحيةً } & \multicolumn{2}{|c|}{ الاقتصادية } & \multicolumn{2}{|c|}{ الاجتماعية } & \multicolumn{2}{|c|}{ العصكرية } & \multicolumn{2}{|c|}{ السياسينية } & \multirow{2}{*}{ التناولتَّالات التصات } \\
\hline$\%$ & s & $\%$ & $s$ & $\%$ & 4 & $\%$ & s & $\%$ & $s$ & $\%$ & $s$ & $\%$ & s & $\%$ & s & $\%$ & s & $\%$ & $s$ & $\%$ & $s$ & \\
\hline 16.9 & 71 & 0 & 0 & 25.8 & 8 & 21 & 9 & 20 & 5 & 0 & 0 & 26 & 8 & 20.9 & 14 & 28.9 & 26 & 0 & 0 & 2 & 1 & المركلمة \\
\hline 41.5 & 175 & 25 & 7 & 25.8 & 8 & 60.5 & 26 & 32 & 8 & 65.5 & 19 & 16 & 5 & 46.3 & 31 & 28.9 & 26 & 48 & 12 & 63.5 & 33 & صفدة ده \\
\hline 33.5 & 141 & 75 & 21 & 0 & 0 & 18.5 & 8 & 44 & 11 & 34.5 & 10 & 42 & 13 & 31.3 & 21 & 40 & 36 & 52 & 13 & 34.6 & 18 & منصدقش \\
\hline 5.7 & 24 & 0 & 0 & 48.4 & 15 & 0 & 0 & 4 & 1 & 0 & 0 & 16 & 5 & 1.5 & 1 & 2.2 & 2 & 0 & 0 & 0 & 0 & صلوندة \\
\hline 100 & 421 & 100 & 28 & 100 & 31 & 100 & 43 & 100 & 25 & 100 & 29 & 100 & 31 & 100 & 67 & 100 & 90 & 100 & 25 & 100 & 52 & الإجمالي \\
\hline
\end{tabular}

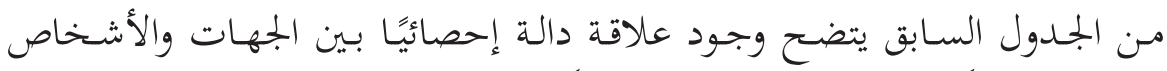

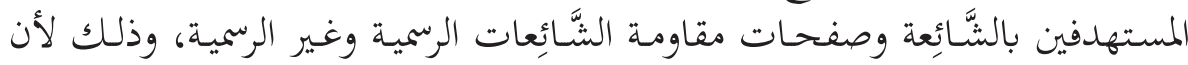

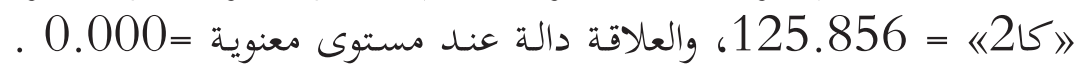

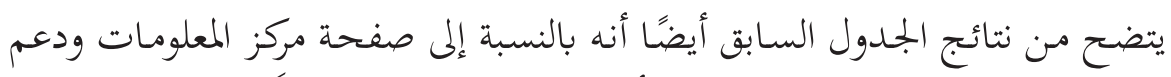

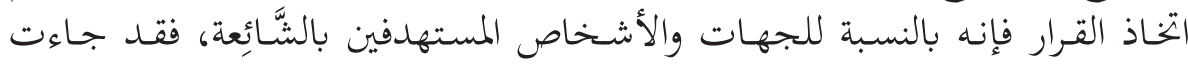

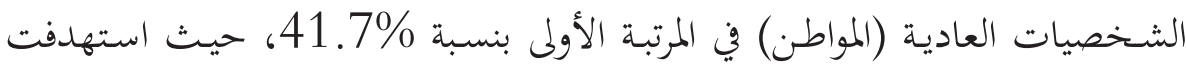

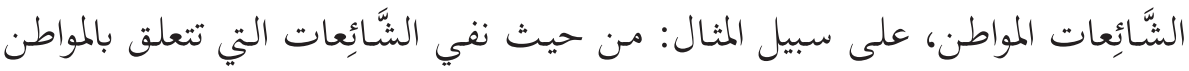

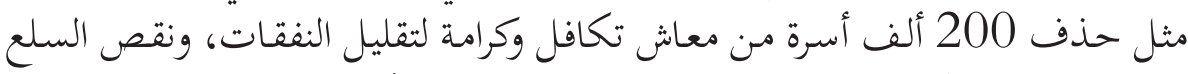

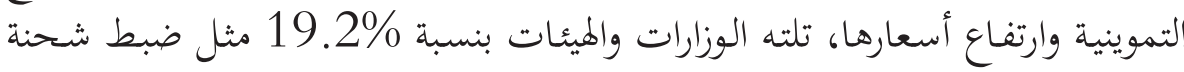

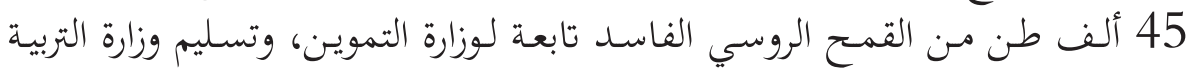

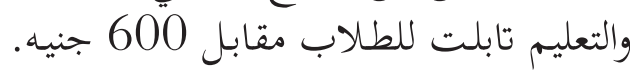

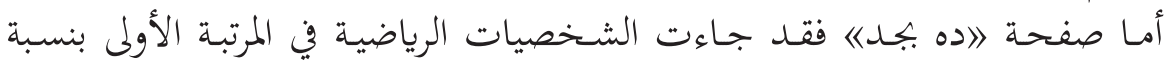

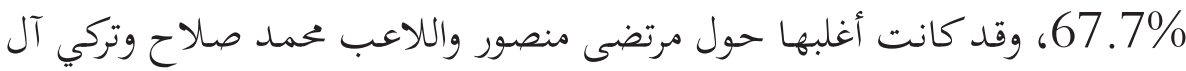
الشيخ، بينما صفحة \متصدقش) جاء الرؤساء في المرتبة الأولى بنسبة 
شائعات تتعلق بالسيد الرئيس وقيامه ببناء الكنائس لاجتذاب المسيحيين للتصويت،

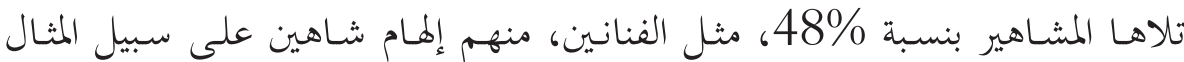

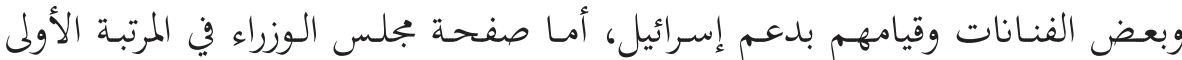

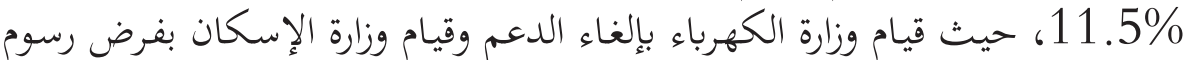
جديدة على العمارات السكنية.

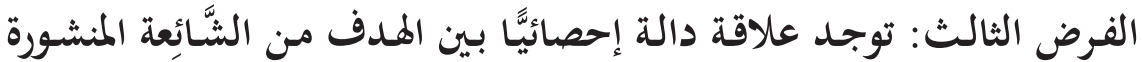

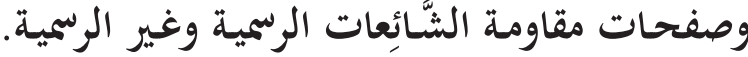

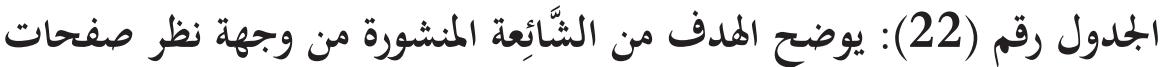
مقاومة الثَّائعة.

\begin{tabular}{|c|c|c|c|c|c|c|c|c|c|c|c|c|c|c|c|c|c|c|}
\hline \multicolumn{2}{|c|}{ الإجمالي } & \multicolumn{2}{|c|}{ يمكن تحلديده } & \multicolumn{2}{|c|}{ تحريض } & \multicolumn{2}{|c|}{ فإثبات } & \multicolumn{2}{|c|}{ الكراثية } & \multicolumn{2}{|c|}{ التشويه } & \multicolumn{2}{|c|}{ التضليل } & \multicolumn{2}{|c|}{ الربث } & \multicolumn{2}{|c|}{ التعاطف } & \multirow{2}{*}{ 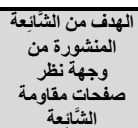 } \\
\hline$\%$ & $s$ & $\%$ & $s$ & $\%$ & $s$ & $\%$ & s & $\%$ & ك & $\%$ & ك & $\%$ & s & $\%$ & s & $\%$ & s & \\
\hline 16.9 & 71 & 19 & 14 & 0 & 0 & 28 & 7 & 23.8 & 5 & \begin{tabular}{|l|l|}
9.8 \\
\end{tabular} & 8 & 18.4 & 17 & 21.3 & 20 & 0 & 0 & صفحة مركز \\
\hline 41.5 & 17 & 4 & \begin{tabular}{|l|}
35 \\
\end{tabular} & 100 & 4 & 48 & 12 & 33.4 & 7 & 64.2 & 52 & 8 & 21 & \begin{tabular}{|l|l|}
28.7 \\
\end{tabular} & 27 & 56.6 & 17 & صفحة ده بج \\
\hline 33.5 & 141 & 34 & \begin{tabular}{|l|}
25 \\
\end{tabular} & $\infty$ & 0 & 24 & 6 & \begin{tabular}{|l|}
42.8 \\
\end{tabular} & 9 & 25.9 & 21 & 31.9 & \begin{tabular}{|l|}
30 \\
\end{tabular} & \begin{tabular}{|l}
50 \\
\end{tabular} & \begin{tabular}{|l|}
47 \\
\end{tabular} & 43.3 & 13 & صفحة متصدقشى \\
\hline 5.7 & 24 & 0 & 0 & 0 & 0 & 0 & 0 & 0 & 0 & 0 & 0 & 25.5 & 24 & 0 & 0 & 0 & 0 & صفحة مجلَ \\
\hline 100 & 21 & 100 & 74 & 100 & 4 & & & 100 & & & 81 & 100 & & & 94 & 100 & & جيمالر \\
\hline
\end{tabular}

$$
\text { درجات حرية=21 }
$$$$
\text { مستوى معنوية =000 }
$$

$136.44={ }^{2}$

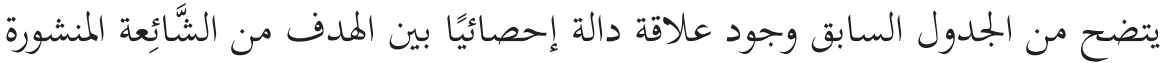

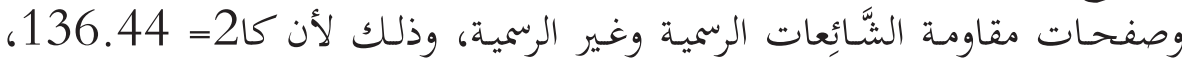
والعلاقة دالة عند مستوى معنوية =000

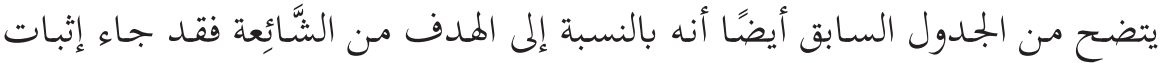

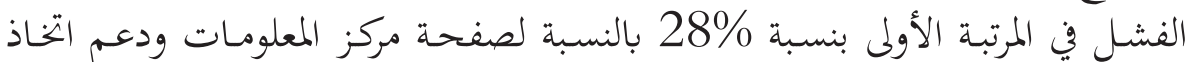

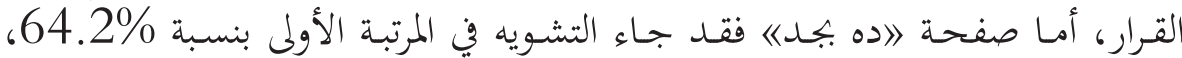

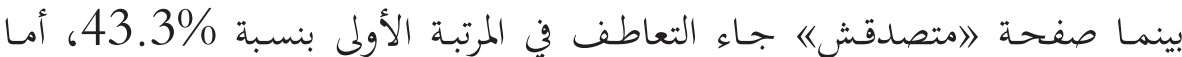

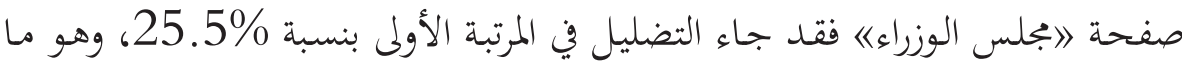

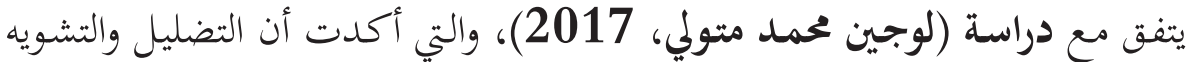

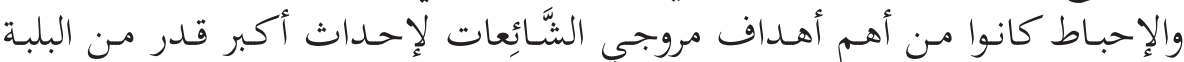

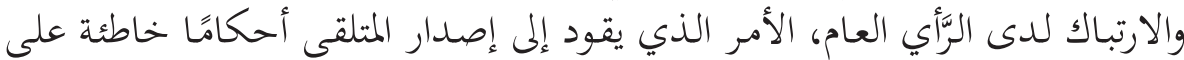


ثانيًا: نتائج اختبارات فروض الدراسة الميدانية:

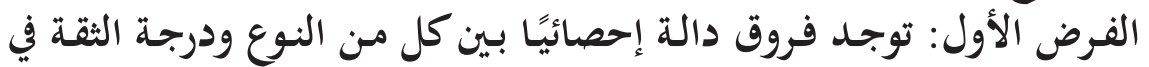

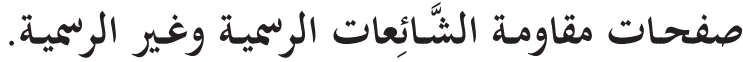

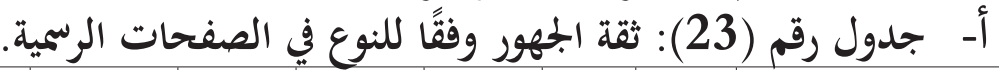

\begin{tabular}{|c|c|c|c|c|c|c|c|}
\hline مستوى & \multirow[t]{2}{*}{ قيمة (ت) } & درجات & 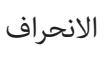 & | المتوسط & العدد & 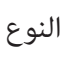 & \multirow[t]{4}{*}{ الثقة في الصفحات الرسمية } \\
\hline الدلالة & & الحرية & المعياري & & & & \\
\hline \multirow[t]{2}{*}{0.001} & \multirow[t]{2}{*}{7.177} & \multirow[t]{2}{*}{398} & 0.563 & 2.54 & 236 & ذكر & \\
\hline & & & 0.594 & 2.12 & 164 & أنثر & \\
\hline
\end{tabular}

يتضح مـ الجـدول السـابق وجـود علاقة دالة إحصائيًا بـين درجـة الثقـة في الصفحات غير الرسمية والنوع؛ لأن قيمة ت =

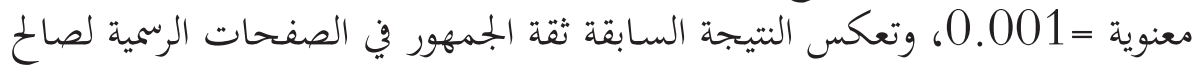
الذكور بمتوسط 2.54.

ب-جدول رقم (24): ثقة الجهور وفقًا للنوع في الصفحات غير الرسمية

\begin{tabular}{|c|c|c|c|c|c|c|c|}
\hline مستوى & قيمة (ت) & الحرية & الانحراف & المتوسط & العدد & النوع & الثقة في الصفحات غير \\
\hline \multirow[t]{2}{*}{0.000} & \multirow[t]{2}{*}{0.752} & \multirow[t]{2}{*}{98} & 0.76748 & 1.8093 & 236 & ذكر & \\
\hline & & & 0.57687 & 1.7561 & 164 & أنثى & \\
\hline
\end{tabular}

يتضح من الجـدول السـابق وجـود علاقـة دالة إحصائيَّا بين درجـة الثقـة في الصفحات الرسميـة والنوع؛ لأن قيمة ت = معنوية =0.000، وتعكس النتيجة السابقة ثقة الجمههور في الصفحات التهبة الرسمية لصالح الذكور بمتوسط 1.8093. 
الفـرض الثالي: توجـد فروق دالة إحصائيًا بين كل مـن المستوى الاقتصـادي

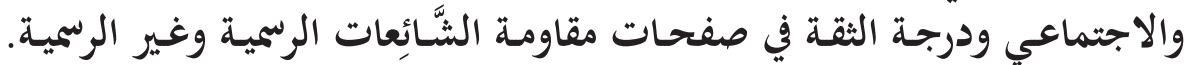

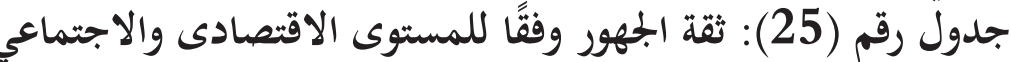

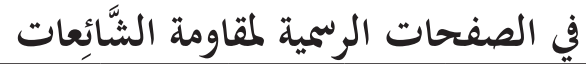

\begin{tabular}{|c|c|c|c|c|c|c|c|}
\hline مستوى الدلالة & قيمة & درجات الحرية & الانحراف & المتوسط & العدد & الاقتصتوى & \multirow{4}{*}{ الثقة في الصفحات الرسمية } \\
\hline \multirow[t]{3}{*}{0.135} & \multirow[t]{3}{*}{2.010} & \multirow[t]{3}{*}{2} & 0.718 & 2.48 & 92 & منخفض & \\
\hline & & & 0.539 & 2.33 & 232 & متوسط & \\
\hline & & & 0.670 & 2.37 & 76 & مرتفع & \\
\hline
\end{tabular}

يتضح من الجمدول السابق عدم وجود فروق دالة إحصائيًّا بين المستوى الاقتصادي

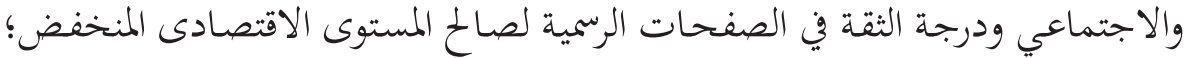

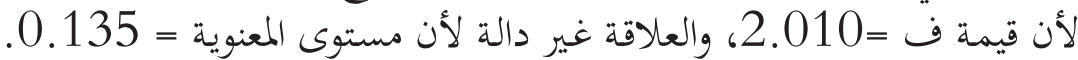

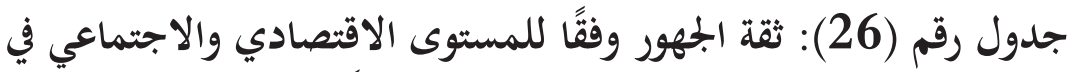

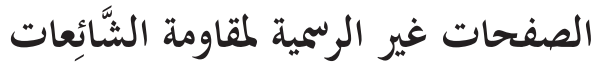

\begin{tabular}{|c|c|c|c|c|c|c|c|}
\hline مستوى الدلالة & قيمة & الحرية & الانعراف المعاري & المتوسط & 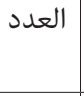 & الاقتصادي & \multirow{4}{*}{ الثقة في الصفحات غير الرسمية } \\
\hline \multirow[t]{3}{*}{0.33} & \multirow[t]{3}{*}{1.110} & \multirow[t]{3}{*}{2} & 0.75213 & 1.6957 & 92 & منخفض & \\
\hline & & & 0.64383 & 1.8233 & 232 & 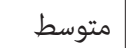 & \\
\hline & & & 0.77142 & 1.7895 & 76 & | مرتفع & \\
\hline
\end{tabular}

يتضح من الجمدول السابق عدم وجود فروق دالة إحصائيَّا بين المستوى الاقتصادي

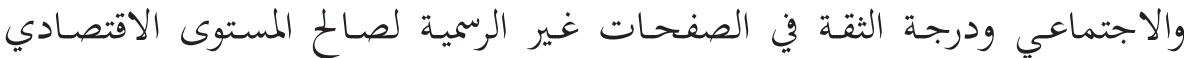
المتوسط؛ لأن قيمة ف =1.110، والعلاقة غير دالة عند مستوى معنوية =0.33. 


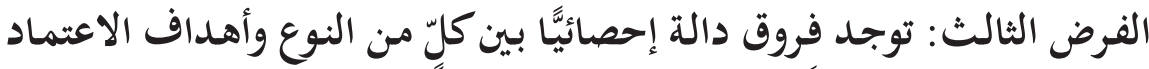

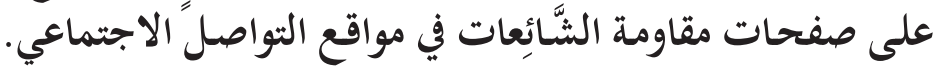

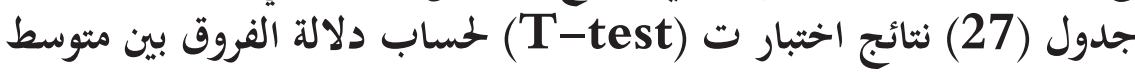

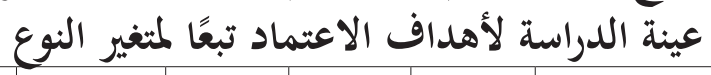

\begin{tabular}{|c|c|c|c|c|c|c|}
\hline مستوى الدلالة & قيمة (ت) & الانحراف الكعياري & المتوسط & العدد & النوع & أهداف الاعتماد \\
\hline \multirow[t]{2}{*}{0.006} & \multirow[t]{2}{*}{2.752} & 1.04 & 4.85 & 236 & ذكر & \multirow[t]{2}{*}{ الفهم } \\
\hline & & 0.86 & 4.59 & 164 & أنثى & \\
\hline \multirow[t]{2}{*}{0.001} & \multirow[t]{2}{*}{5.629} & 1.73 & 9.63 & 236 & ذكر & \multirow[t]{2}{*}{ التوجيه } \\
\hline & & 1.64 & 8.66 & 164 & أنثى & \\
\hline \multirow[t]{2}{*}{0.001} & \multirow[t]{2}{*}{3.948} & 1.23 & 4.36 & 236 & ذكر & \multirow[t]{2}{*}{ الهروب } \\
\hline & & 1.42 & 3.83 & 164 & أنثى & \\
\hline \multirow[t]{2}{*}{0.001} & \multirow[t]{2}{*}{5.638} & 3.46 & 18.83 & 236 & ذكر & \multirow[t]{2}{*}{ إجمالي أهداف الاعتماد } \\
\hline & & 2.76 & 17.07 & 164 & أنثى & \\
\hline
\end{tabular}

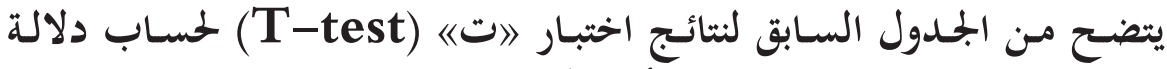

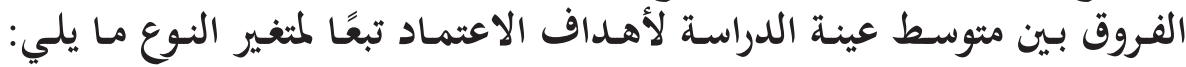

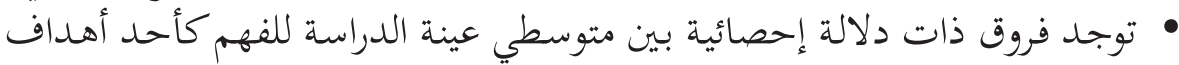

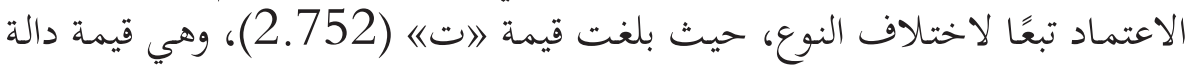

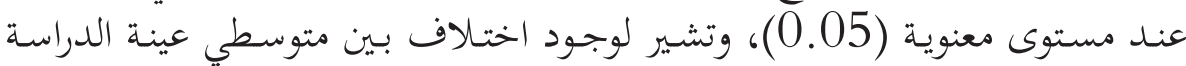

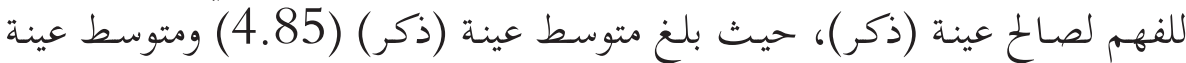

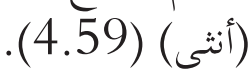
توجد فروق ذات دلالة إحصائية بين متوسطي عينة الدراسة للتوجيه كأحد أهداف

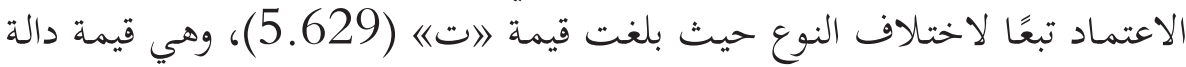

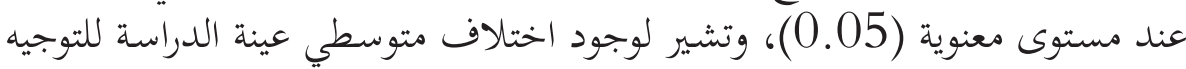

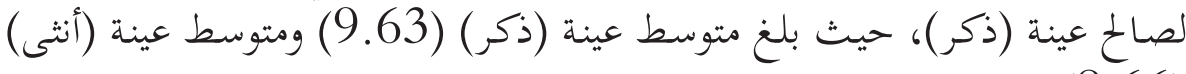
. (8.66)

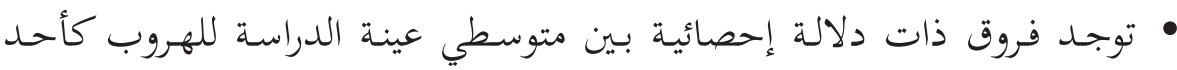

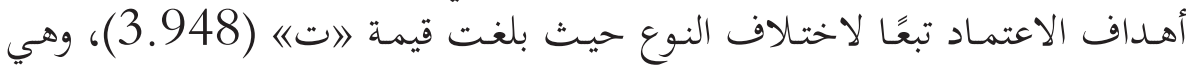

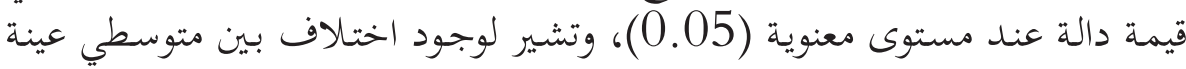

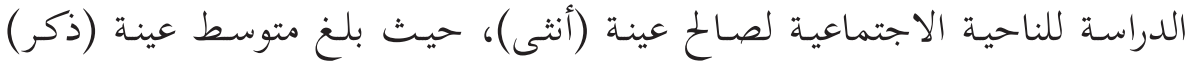

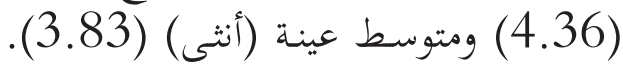


• توجـد فروق ذات دلالة إحصائية بين متوسطي عينة الدراسة لإجمالي أهـداف

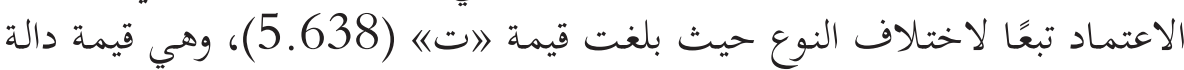

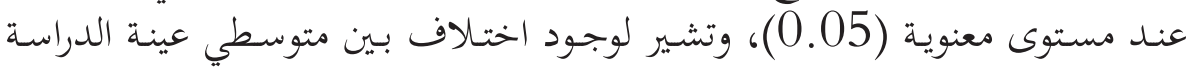

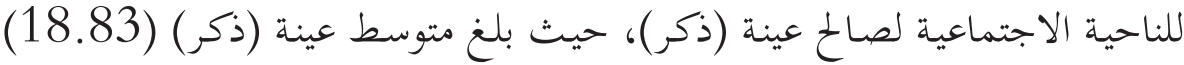

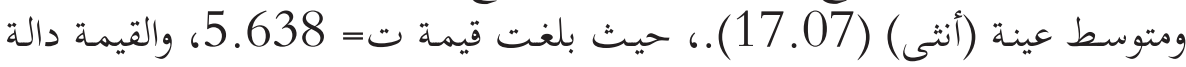

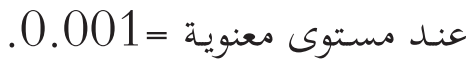

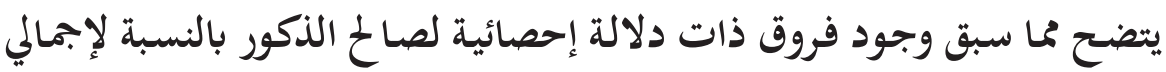

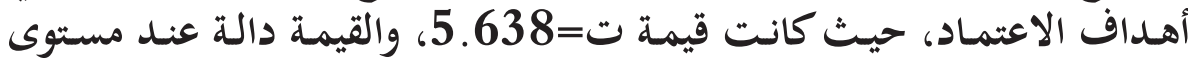

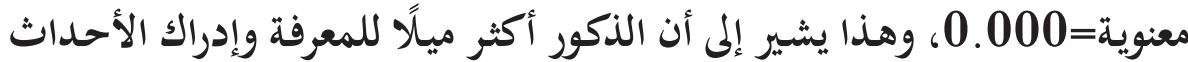

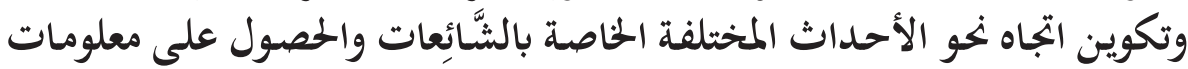

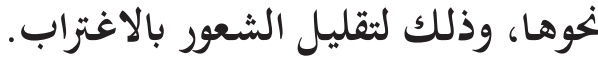

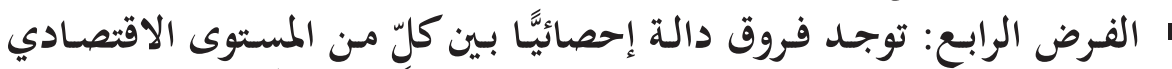

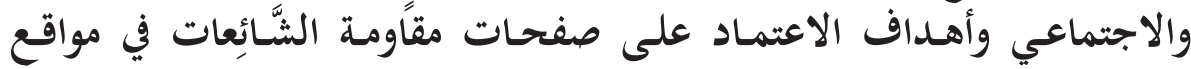
التواصل الآجتماعي.

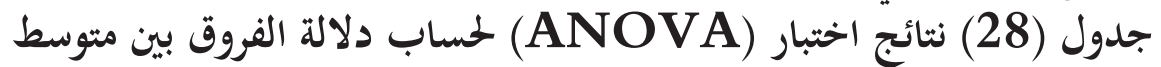

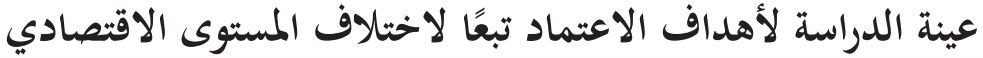

\begin{tabular}{|c|c|c|c|c|c|c|}
\hline مستوى الدلالة & قيمة & الانحراف & المتوسط & العدد & الاقستوى & أهداف الاعتماد \\
\hline \multirow[t]{3}{*}{0.07} & \multirow{3}{*}{2.696} & 1.07 & 4.78 & 92 & منخفض & \multirow[t]{3}{*}{ الفهم } \\
\hline & & 0.86 & 4.66 & 232 & متوسط & \\
\hline & & 1.15 & 4.95 & 76 & مرتفع & \\
\hline \multirow[t]{3}{*}{0.001} & \multirow[t]{3}{*}{9.264} & 1.85 & 9.48 & 92 & منخفض & \multirow[t]{3}{*}{ التوجيه } \\
\hline & & 1.58 & 8.93 & 232 & متوسط & \\
\hline & & 1.97 & 9.84 & 76 & مرتفع & \\
\hline \multirow[t]{3}{*}{0.4} & \multirow[t]{3}{*}{0.922} & 1.31 & 4.04 & 92 & منخفض & \multirow[t]{3}{*}{ الهروب } \\
\hline & & 1.24 & 4.12 & 232 & متوسط & \\
\hline & & 1.63 & 4.32 & 76 & مرتفع & \\
\hline \multirow[t]{3}{*}{0.005} & \multirow[t]{3}{*}{5.459} & 2.91 & 18.30 & 92 & منخفض & \multirow[t]{3}{*}{ إجمالي أهداف الاعتماد } \\
\hline & & 3.06 & 17.71 & 232 & متوسط & \\
\hline & & 4.17 & 19.11 & 76 & مرتفع & \\
\hline
\end{tabular}

يتضح من الجدول السابق لنتائج اختبار (ANOVA) لحساب دلالة الفروق بين 


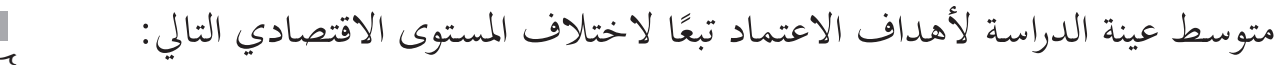

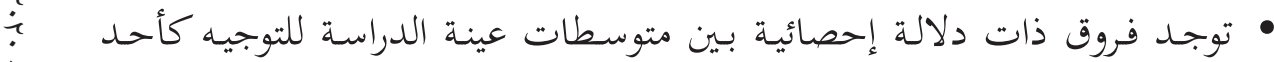

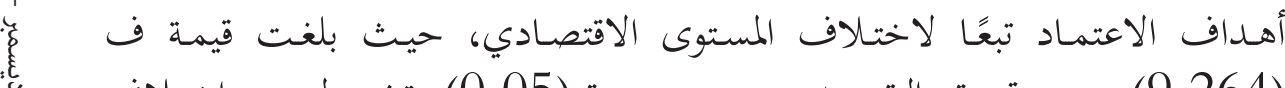

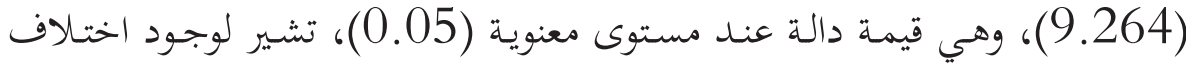

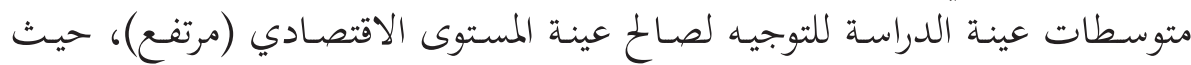

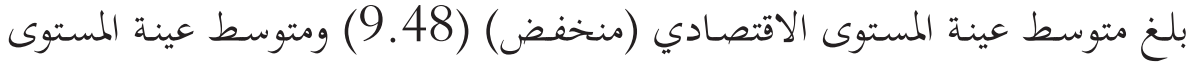

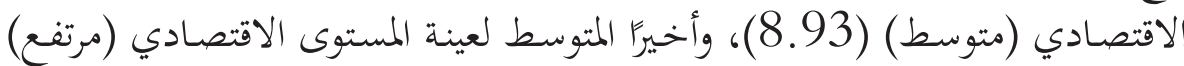

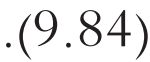

• بينما لا توجـد فروق ذات دلالة إحصائية بين متوسطات عينة الدراسة لكل لإنل

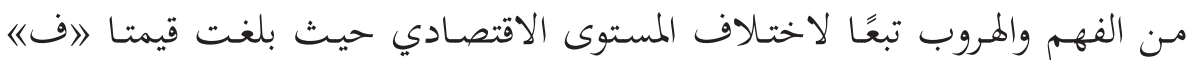

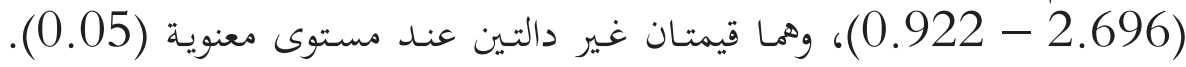

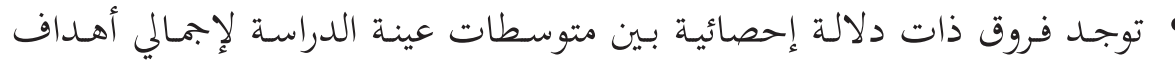

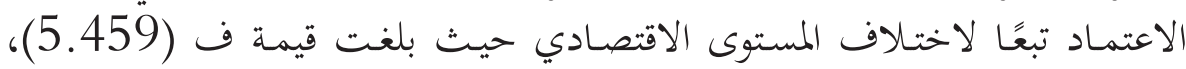

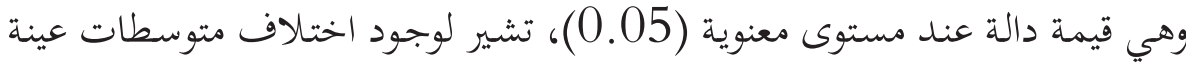

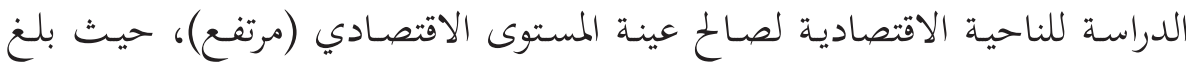

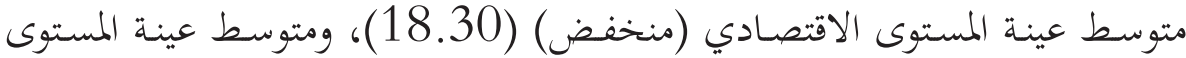

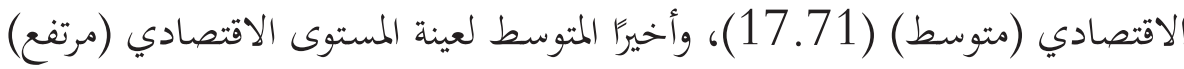

(19.11)

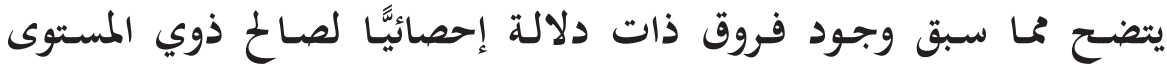

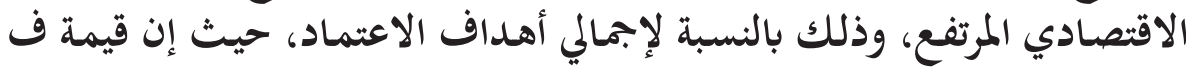

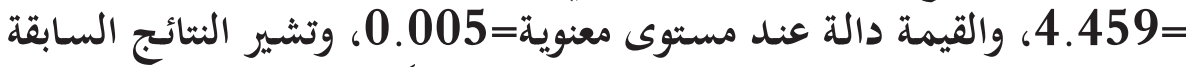

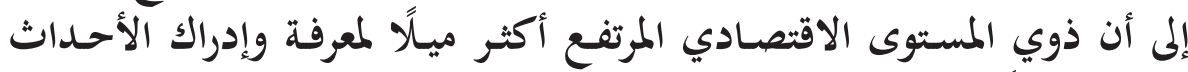

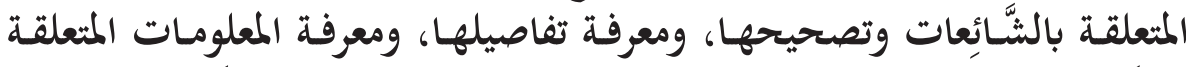

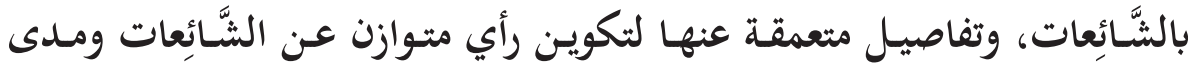

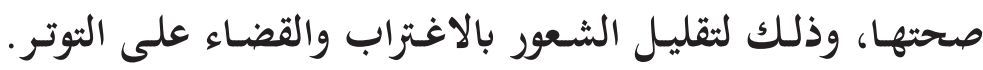




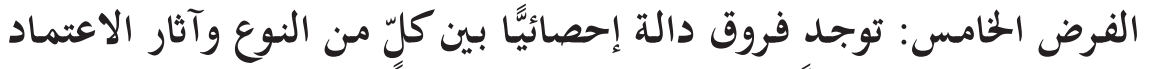

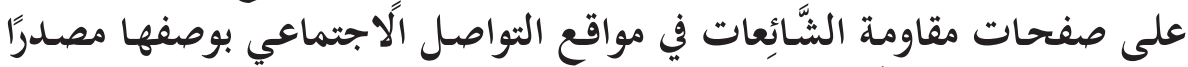

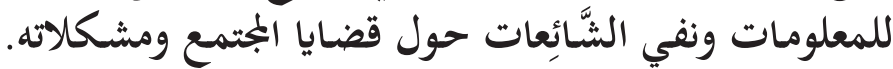

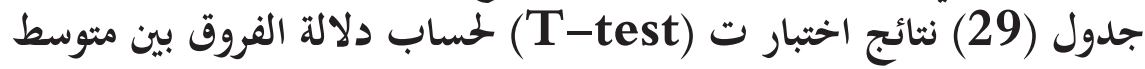

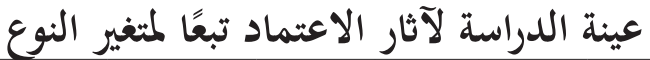

\begin{tabular}{|c|c|c|c|c|c|c|}
\hline مستوى الدلالة & قيمة & الانحراف & المتوسط & العدد & النوع & آثار الاعتماد \\
\hline \multirow[t]{2}{*}{0.004} & \multirow[t]{2}{*}{2.864} & 2.08 & 12.14 & 236 & ذكر & \multirow[t]{2}{*}{ معرفي } \\
\hline & & 1.89 & 11.56 & 164 & أنثى & \\
\hline \multirow[t]{2}{*}{0.001} & \multirow[t]{2}{*}{3.764} & 2.81 & 13.68 & 236 & ذكر & \multirow[t]{2}{*}{ وجداني } \\
\hline & & 2.44 & 12.68 & 164 & أنثى & \\
\hline \multirow[t]{2}{*}{0.001} & \multirow[t]{2}{*}{3.957} & 2.41 & 11.97 & 236 & ذكر & \multirow[t]{2}{*}{ سلوكي } \\
\hline & & 2.40 & 11.00 & 164 & أنثى & \\
\hline \multirow[t]{2}{*}{0.001} & \multirow[t]{2}{*}{4.176} & 6.53 & 37.78 & 236 & ذكر & \multirow{2}{*}{ إجمالي آثار } \\
\hline & & 5.56 & 35.24 & 164 & أنثى & \\
\hline
\end{tabular}

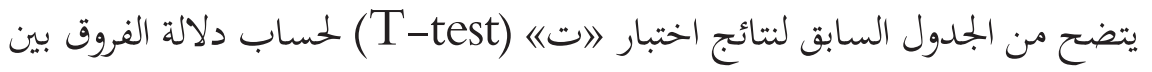

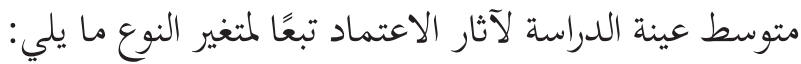

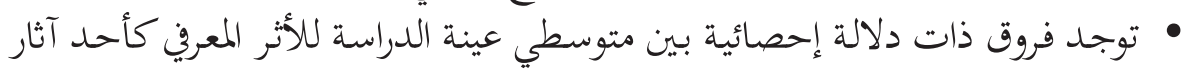

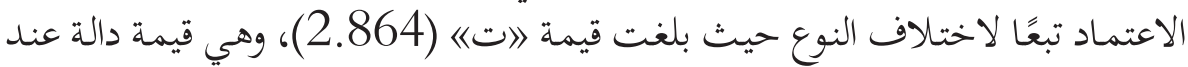

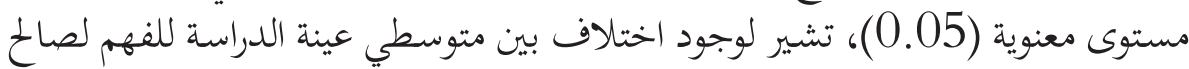
عينة (ذكر)، حيث بلغ متوسط عينة (ذكر) (12.14) ومتوسط عينة (11.56) (11.56).

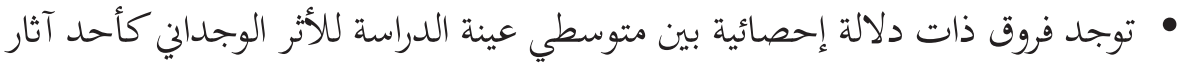

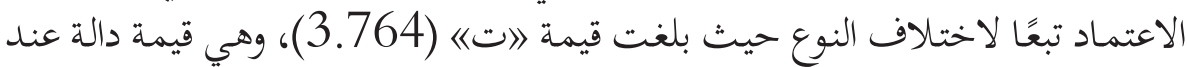

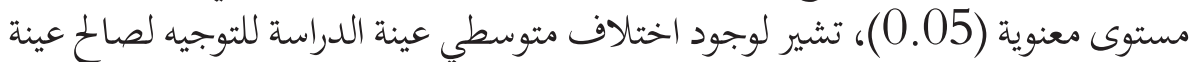

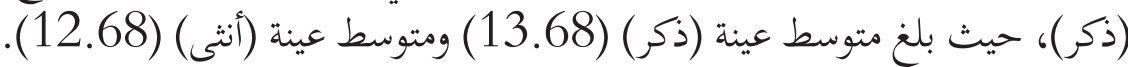

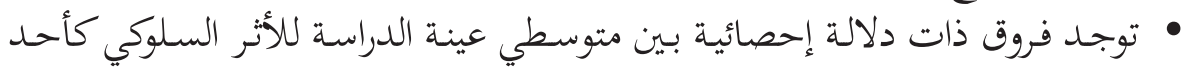

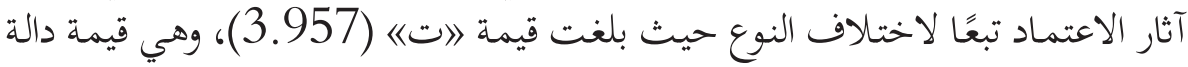

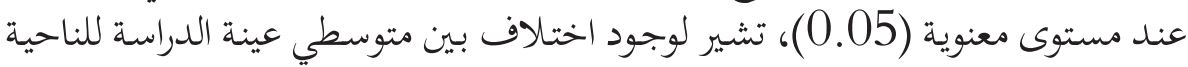

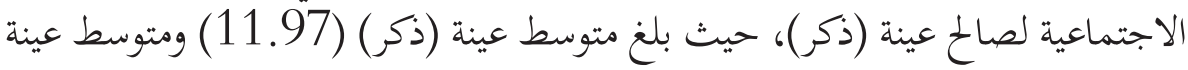
(11.00) (أنثى) (11.00). • توجد فروق ذات دلالة إحصائية بين متوسطي عينة الدراسة لإجمالي آثار الاعتماد تبعًا 
لاختلاف النوع حيث بلغت قيمة 》ات) (4.176)، وهي قيمة دالة عند مستوى معنوية (0.05)، تشير لوجود اختلاف بين متوسطي عينة الدراسة للناحية الاجتماعية لصالح فينة

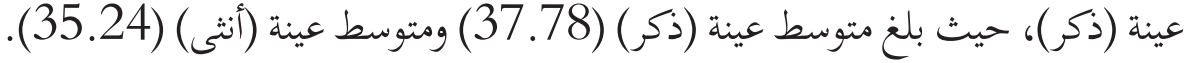

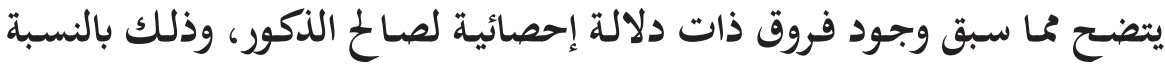

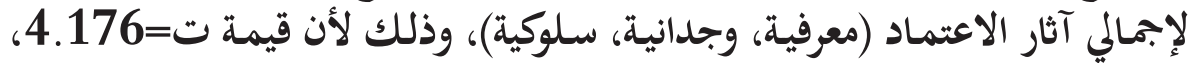

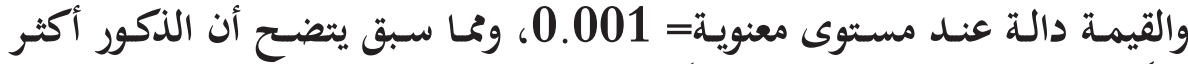

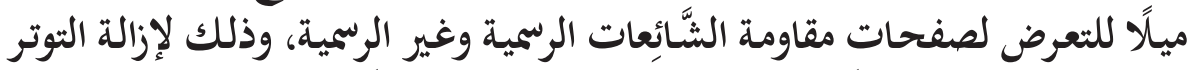

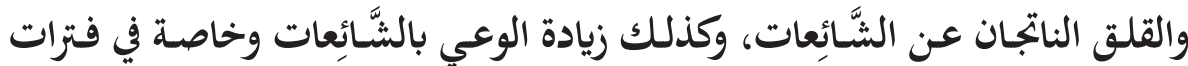

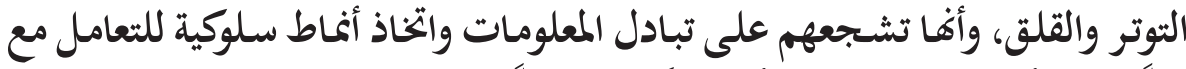

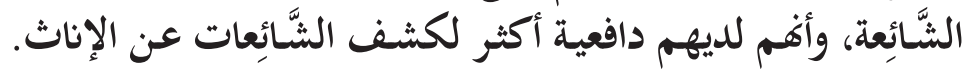

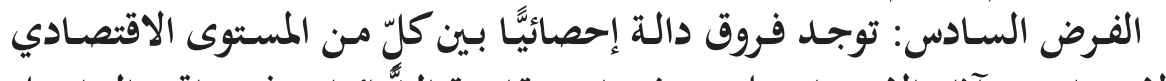

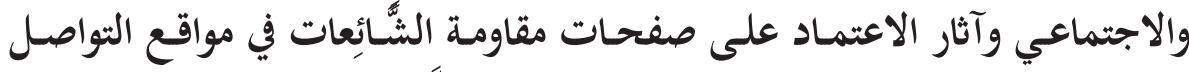

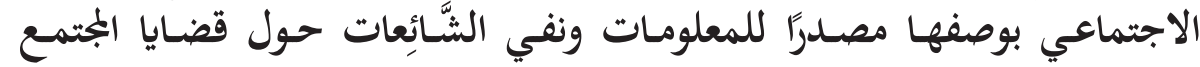
ومشكلاته.

جدول (30) نتائج اختبار (ANOVA) لحساب دلالة الفروق بين متوسط عينة

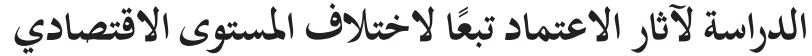

\begin{tabular}{|c|c|c|c|c|c|c|}
\hline مستوى الدلالة & قيمة & الانحراف الكعياري & المتوسط & العدد & الاقتصادى & آثار الاعتماد \\
\hline \multirow[t]{3}{*}{0.01} & \multirow[t]{3}{*}{4.583} & 1.90 & 11.78 & 92 & منخفض & \multirow[t]{3}{*}{ معرفي } \\
\hline & & 1.99 & 11.74 & 232 & متوسط & \\
\hline & & 2.18 & 12.53 & 76 & مرتفع & \\
\hline \multirow[t]{3}{*}{0.001} & \multirow[t]{3}{*}{7.858} & 2.72 & 12.30 & 92 & منخفض & \multirow[t]{3}{*}{ وجداني } \\
\hline & & 2.40 & 13.55 & 232 & متوسط & \\
\hline & & 3.29 & 13.58 & 76 & مرتفع & \\
\hline \multirow[t]{3}{*}{0.001} & \multirow[t]{3}{*}{6.733} & 2.24 & 11.09 & 92 & منخفض & \multirow[t]{3}{*}{ سلوكي } \\
\hline & & 2.34 & 11.48 & 232 & متوسط & \\
\hline & & 2.80 & 12.42 & 76 & مرتفع & \\
\hline \multirow[t]{3}{*}{0.002} & \multirow[t]{3}{*}{6.121} & 5.45 & 35.17 & 92 & منخفض & \multirow{3}{*}{ إجمالي آثار } \\
\hline & & 5.90 & 36.78 & 232 & متوسط & \\
\hline & & 7.71 & 38.53 & 76 & مرتفع & \\
\hline
\end{tabular}

يتبين من الجددول السابق الخاص بالفروق بين أفراد عينة الدراسة تبعًا لمتغير المستوى 


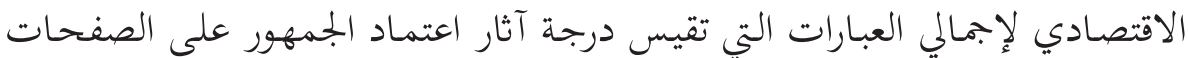

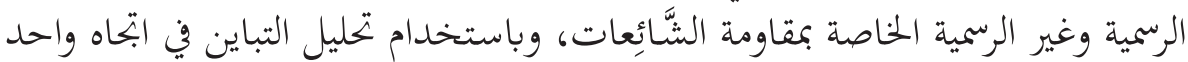
《One Way ANOVA》

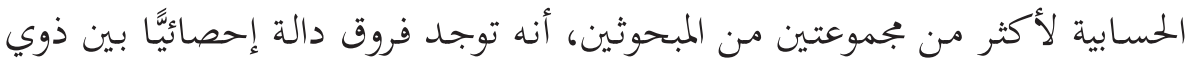

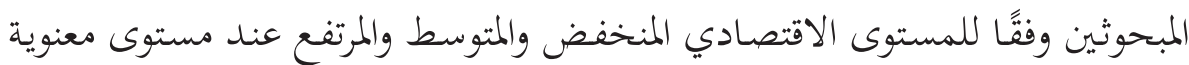

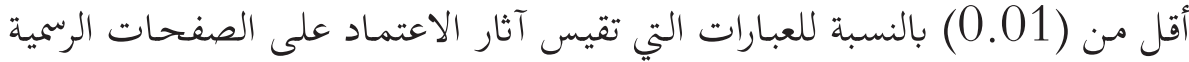

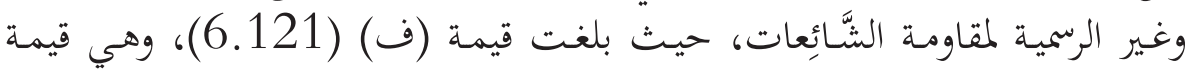

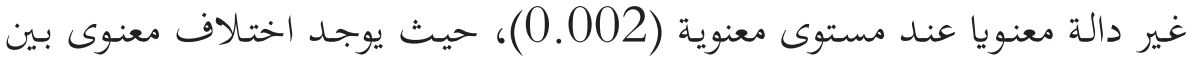

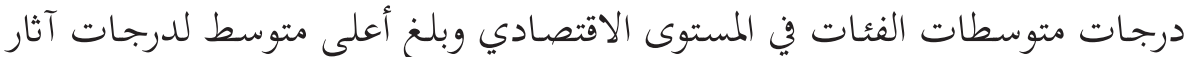

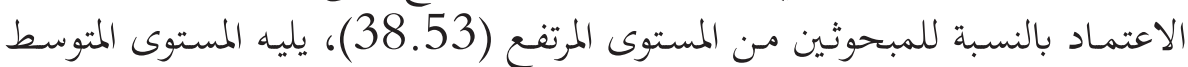

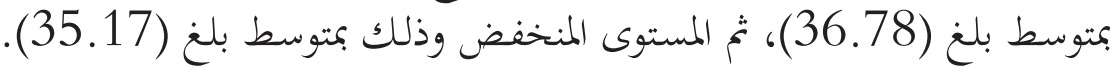

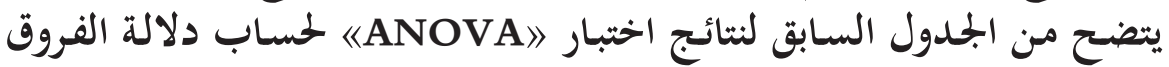

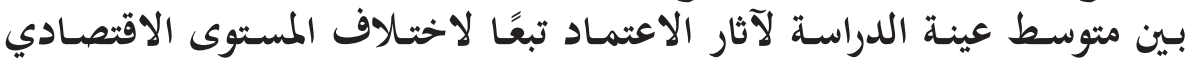
التالي: تصني • توجد فروق ذات دلالة إحصائية بين متوسطات عينة الدراسة للأثثر المعريف

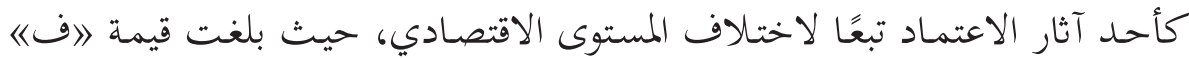

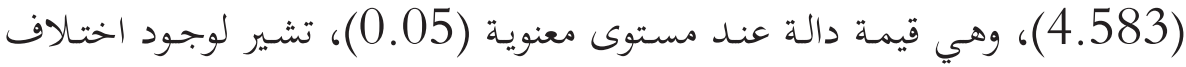

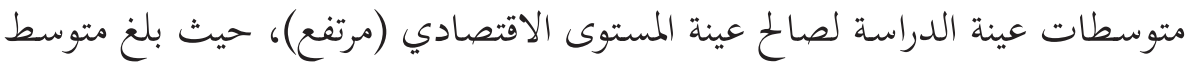

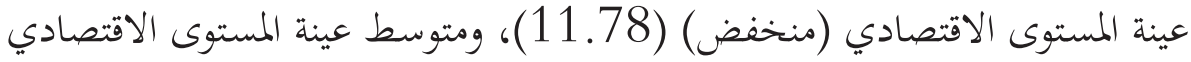
(متوسط) (11.74)، وأخيرًا المتوسط لعينة المستوى الاقتصادي (مرتفع) (12.53) (12.11).

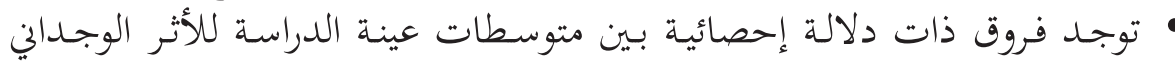

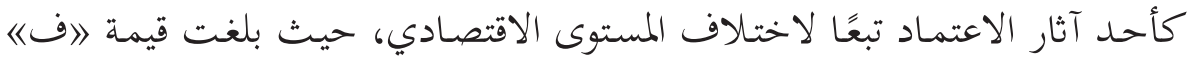

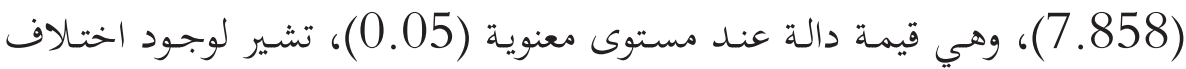

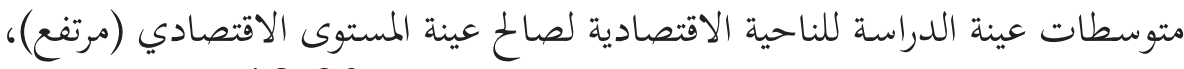

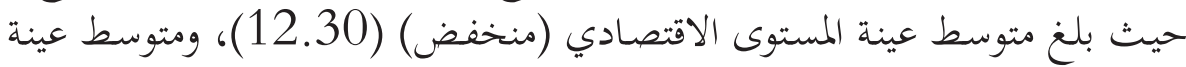

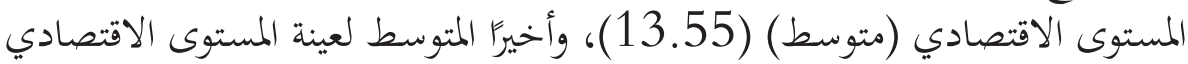

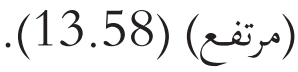

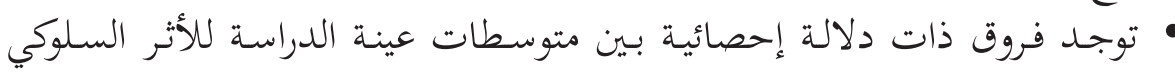

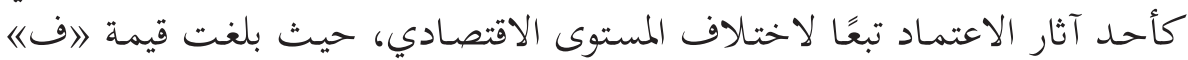

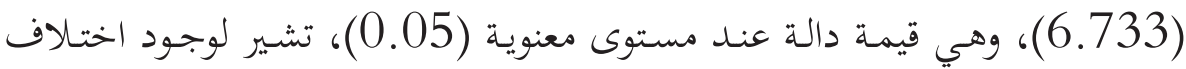


متوسطات عينة الدراسة للناحية الاقتصادية لصالح عينة المستوى الاقتصادي (مرتفع)،

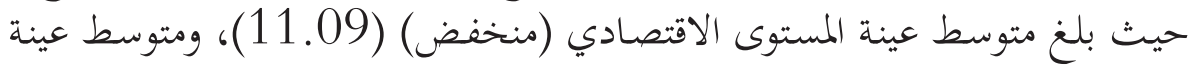

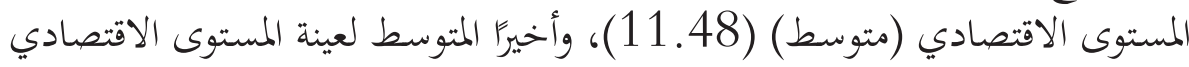

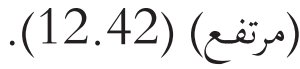

• توجـد فروق ذات دلالة إحصائية بين متوسطات عينة الدراسة لإجمالي آثار

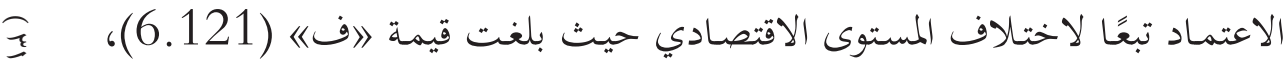

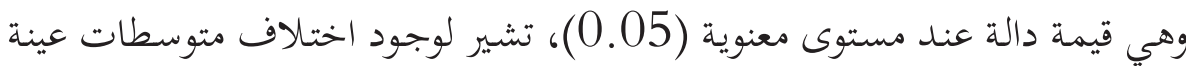

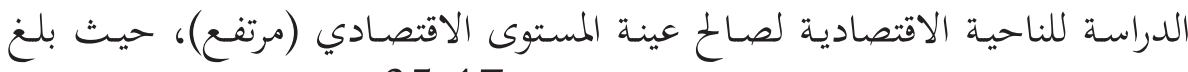

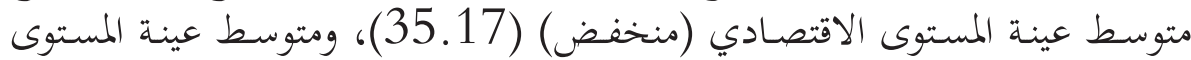

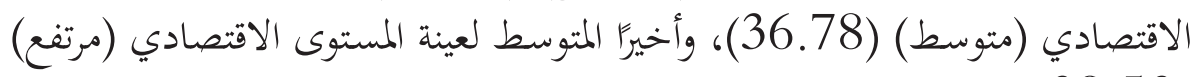
(38.53)

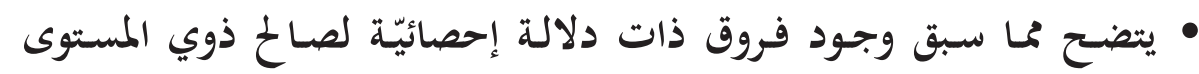

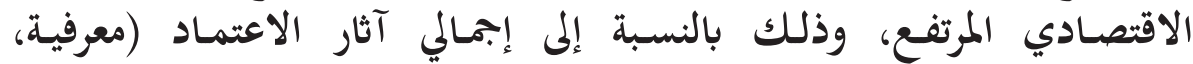

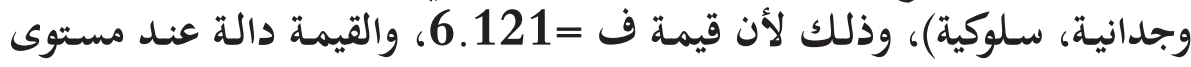

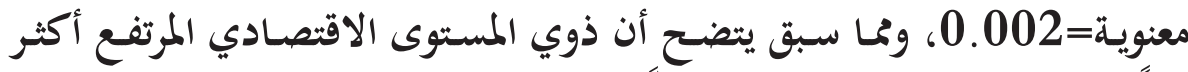

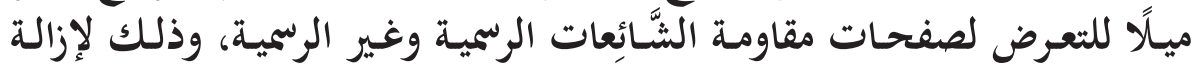

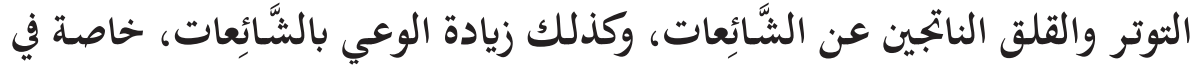

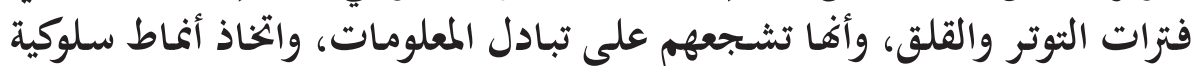

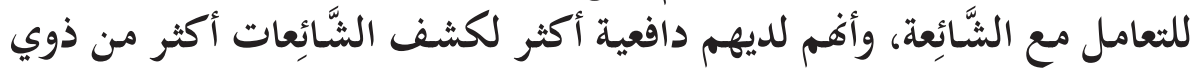

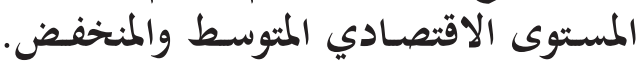




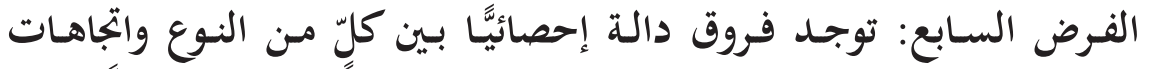

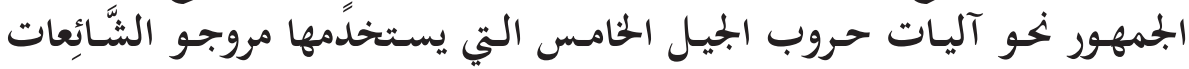
(النواحي الاجتماعية - النواحي الاقتصادية - النواتئ النواحي السياسية).

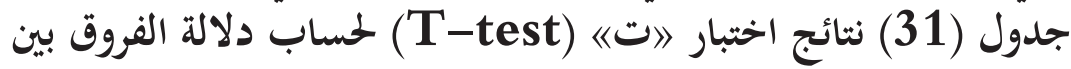
متوسط عينة الدراسة لآليات حروب الجيل الخيل الخامس تبعًا لمثغير النوع:

\begin{tabular}{|c|c|c|c|c|c|c|}
\hline مستوى الدلالة & قيمة & الانحراف الطعياري & المتوسط & العدد & النوع & آليات استخدام الخَّائعاتِ الجِيل \\
\hline \multirow[t]{2}{*}{0.4} & \multirow[t]{2}{*}{0.819} & 1.64 & 7.53 & 236 & ذكر & \multirow[t]{2}{*}{ الناحية الاجتماعية } \\
\hline & & 1.60 & 7.39 & 164 & أنثى & \\
\hline \multirow[t]{2}{*}{0.6} & \multirow[t]{2}{*}{0.49} & 2.50 & 12.15 & 236 & ذكر & \multirow[t]{2}{*}{ الناحية الاقتصادية } \\
\hline & & 2.60 & 12.02 & 164 & أنثى & \\
\hline \multirow[t]{2}{*}{0.02} & \multirow[t]{2}{*}{2.271} & 2.33 & 9.69 & 236 & ذكر & \multirow{2}{*}{ الناحية السياسية } \\
\hline & & 1.91 & 10.20 & 164 & أنثى & \\
\hline
\end{tabular}

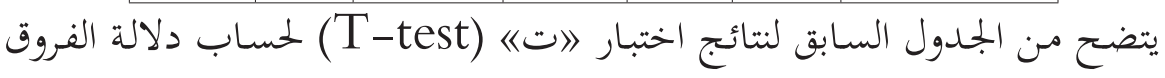

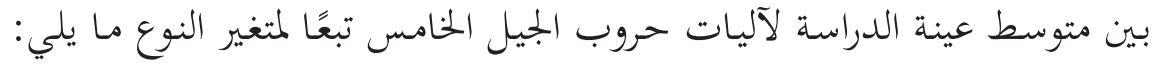

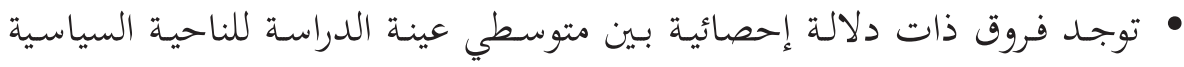

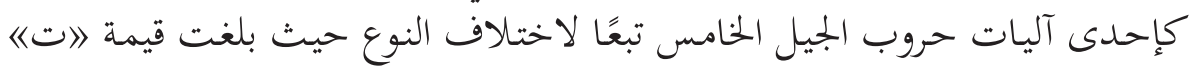

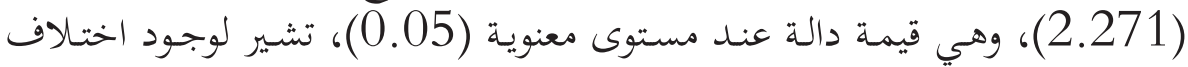

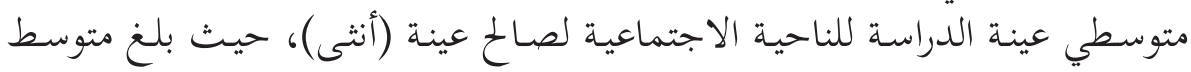

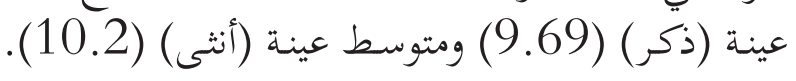

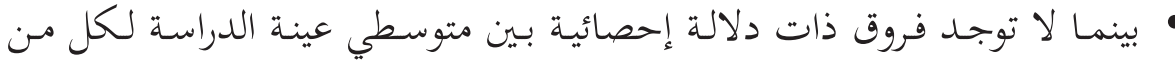

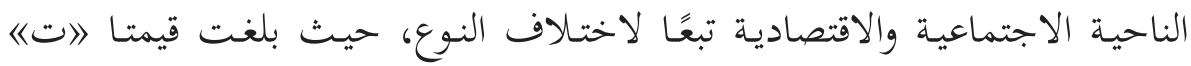

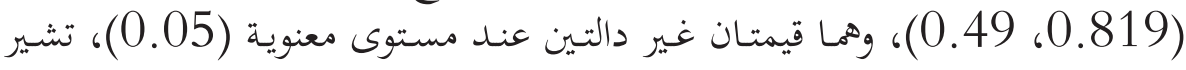

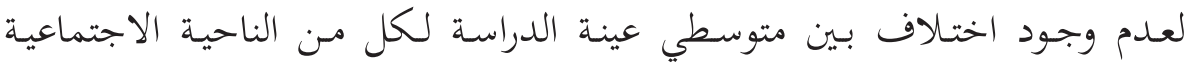

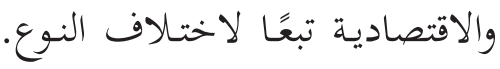

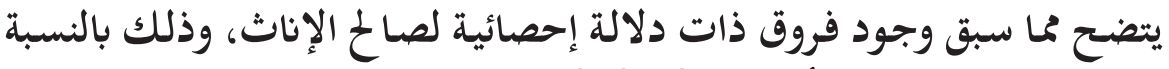

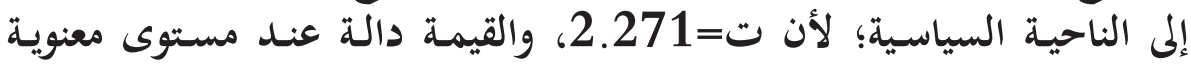
0.02=

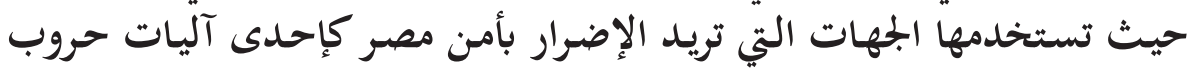




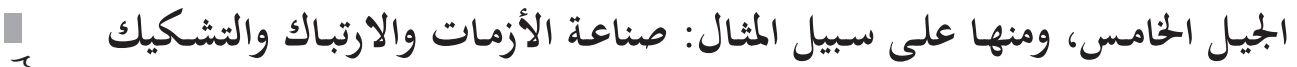

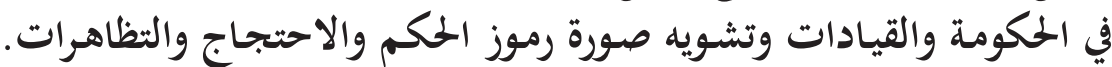

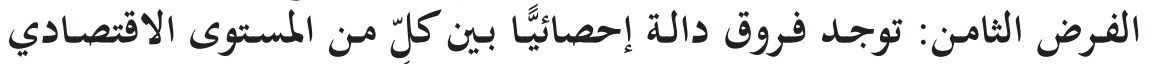

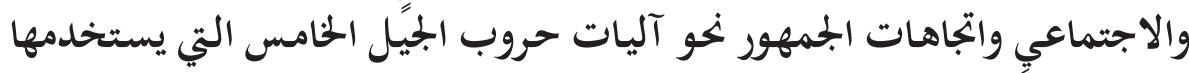

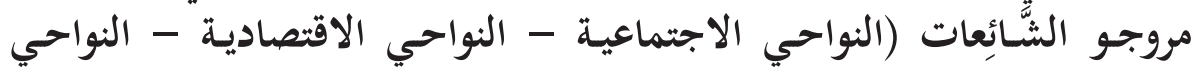

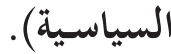

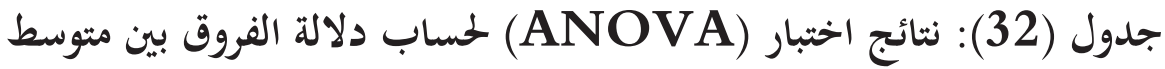

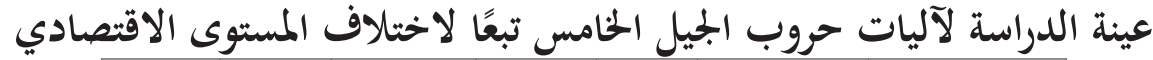

\begin{tabular}{|c|c|c|c|c|c|c|}
\hline مستوى الدلالة & قيمة & الانحراف الطعياري & المتوسط & العدد & الاقتصادي & آليات استخدام \\
\hline \multirow[t]{3}{*}{0.001} & \multirow[t]{3}{*}{16.313} & 1.61 & 6.83 & 92 & منخفض & \multirow{3}{*}{ الاجتماعية } \\
\hline & & 1.68 & 7.48 & 232 & متوسط & \\
\hline & & 1.06 & 8.21 & 76 & مرتفع & \\
\hline \multirow[t]{3}{*}{0.01} & \multirow[t]{3}{*}{4.510} & 2.48 & 11.57 & 92 & منخفض & \multirow{3}{*}{ الاقتصاحة } \\
\hline & & 2.66 & 12.10 & 232 & متوسط & \\
\hline & & 2.09 & 12.74 & 76 & مرتفع & \\
\hline \multirow[t]{3}{*}{0.001} & \multirow[t]{3}{*}{13.927} & 2.27 & 9.17 & 92 & منخفض & \multirow{3}{*}{ الناحية } \\
\hline & & 2.16 & 9.86 & 232 & متوسط & \\
\hline & & 1.72 & 10.89 & 76 & مرتفع & \\
\hline
\end{tabular}

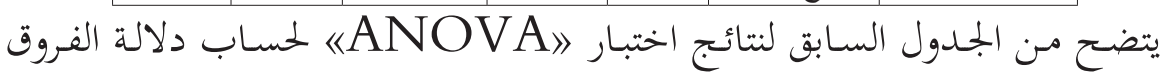

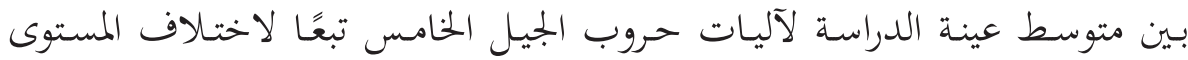

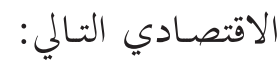

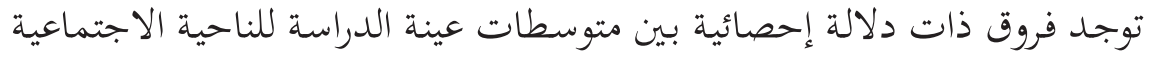

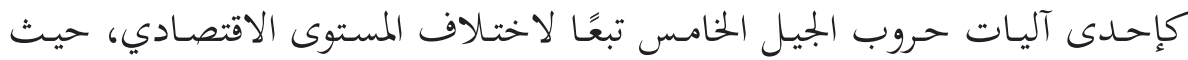

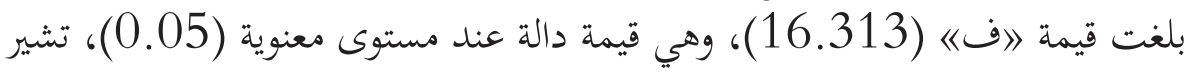

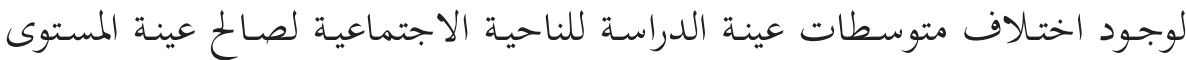

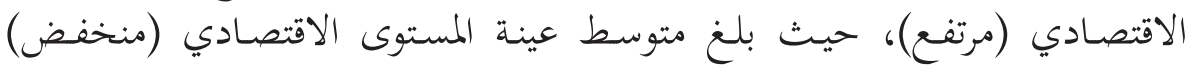

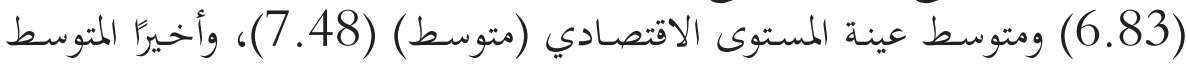
لعينة المستوى الاقتصادي (مرتفع) (8.21). 
توجد فروق ذات دلالة إحصائية بين متوسطات عينة الدراسة للناحية الاقتصادية

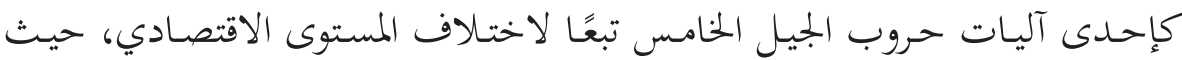

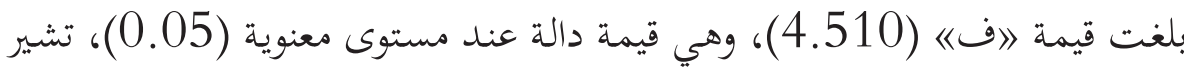

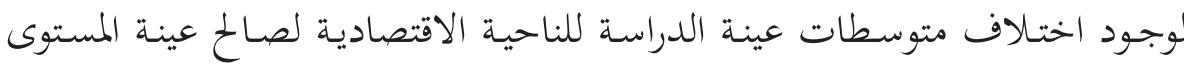

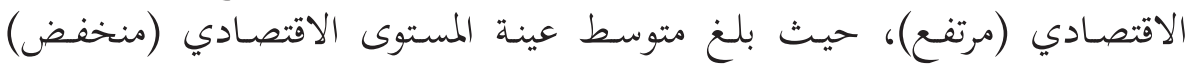

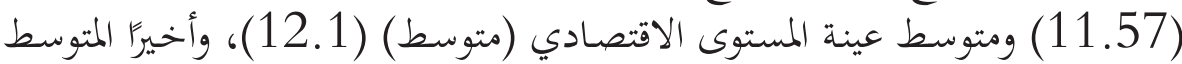

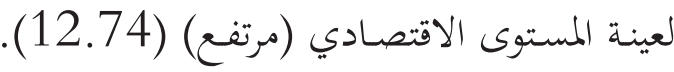

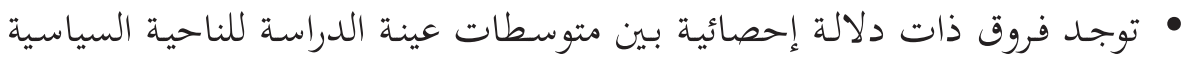

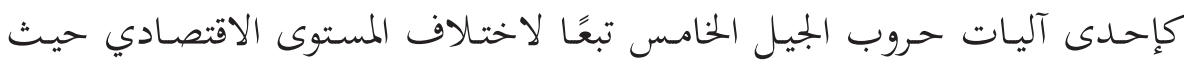

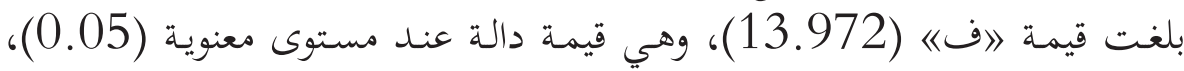

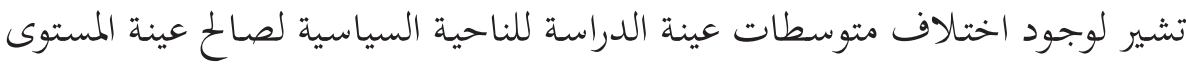

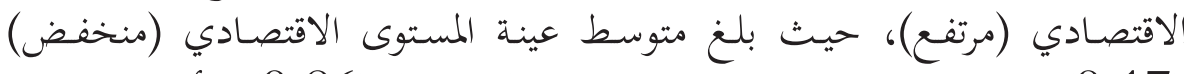

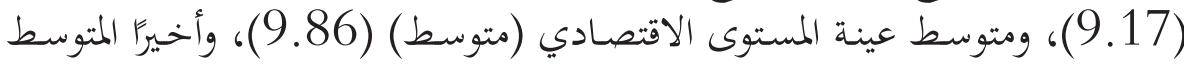

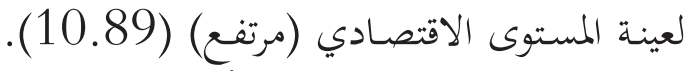

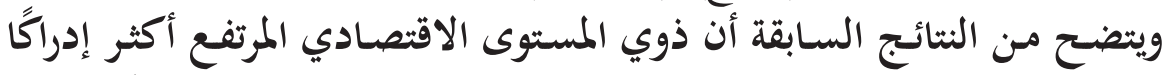

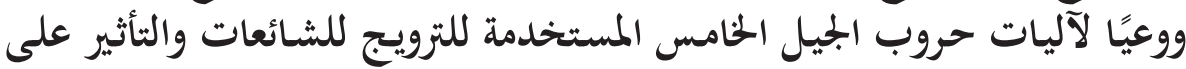

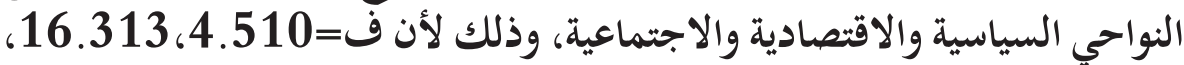

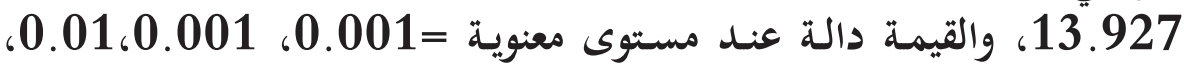

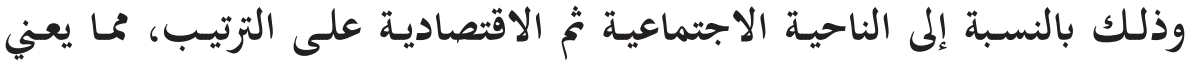

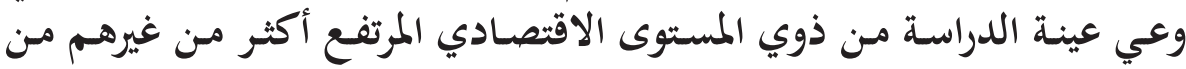

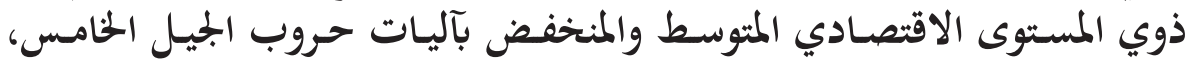

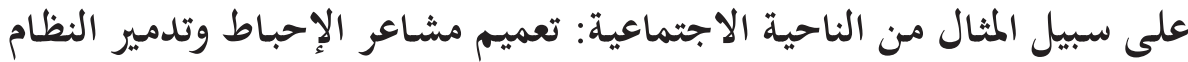

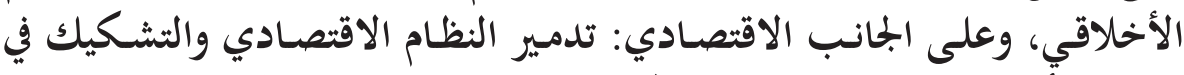

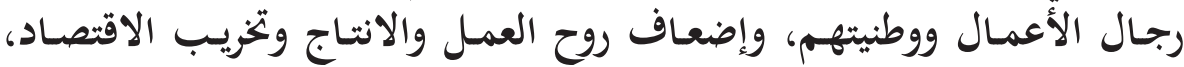

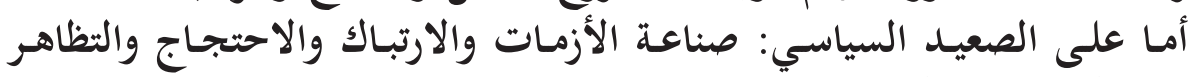

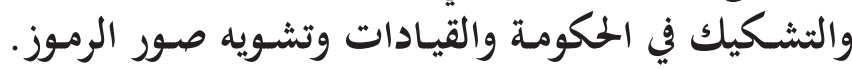

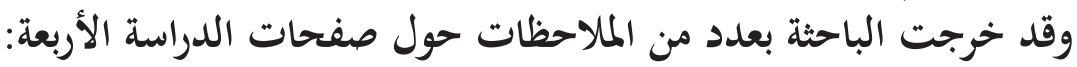

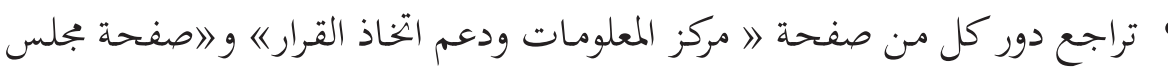

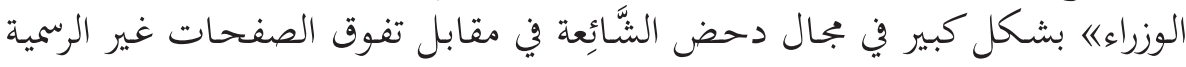

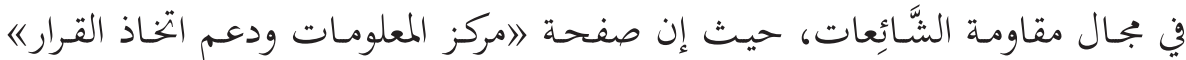




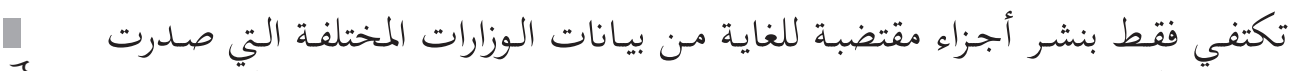

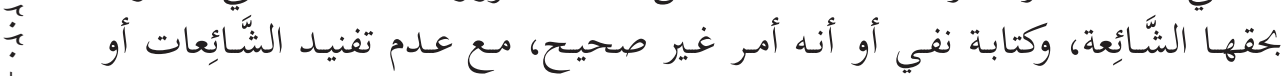

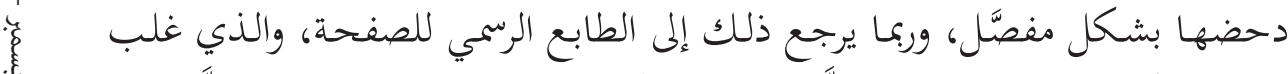

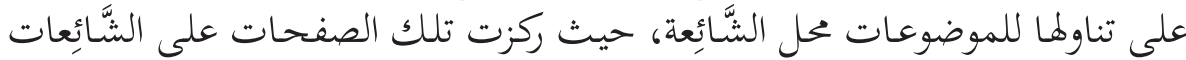

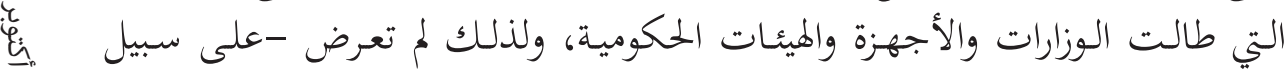

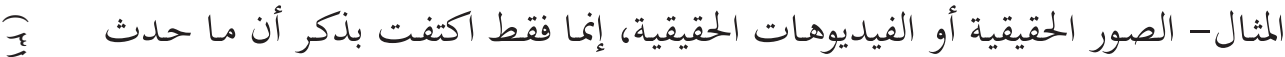

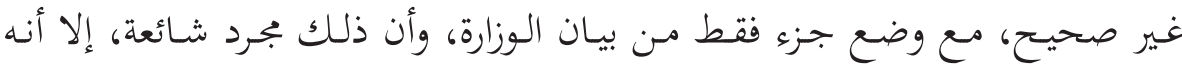

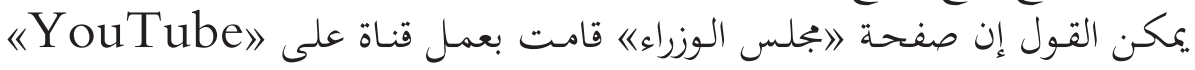

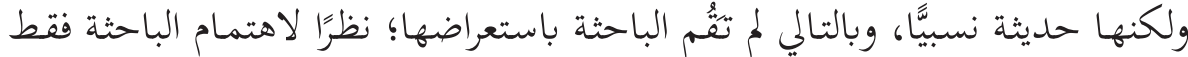

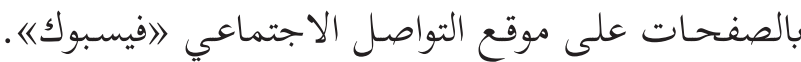

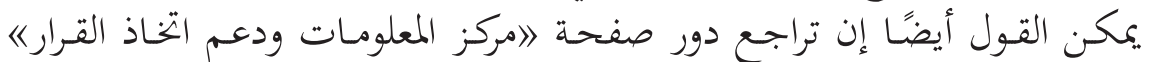

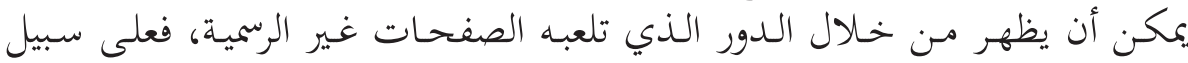

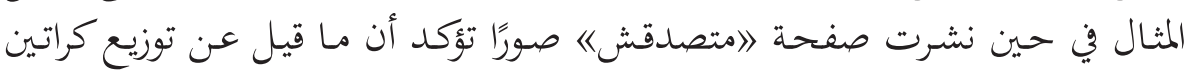

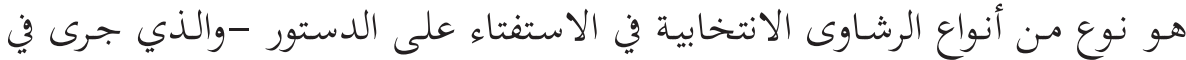

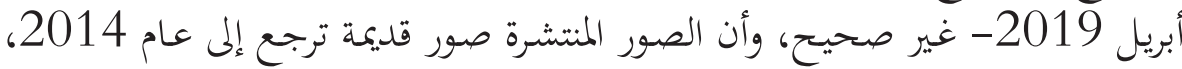

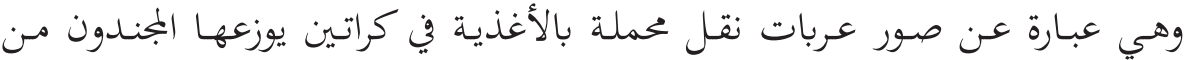

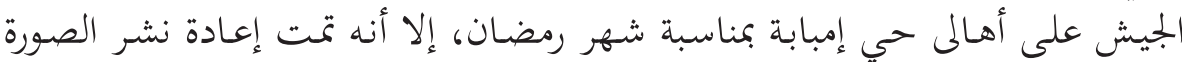

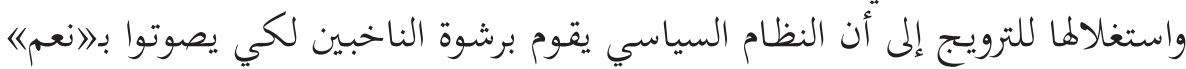
في الاستفتاء على الدستور .

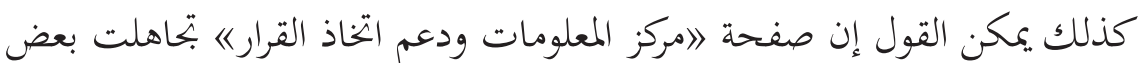

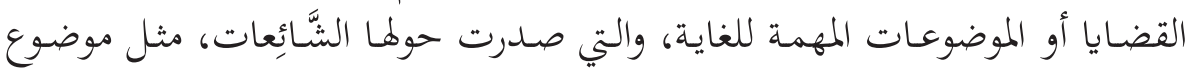

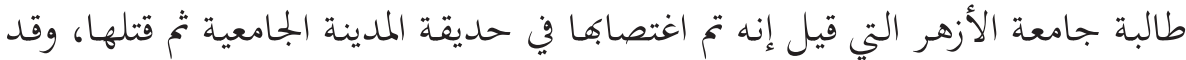

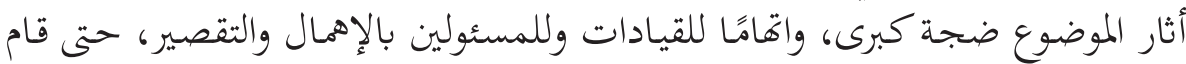

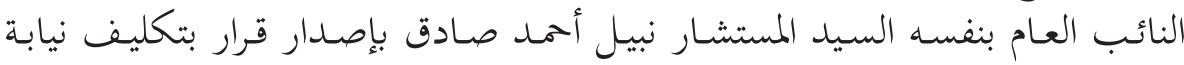

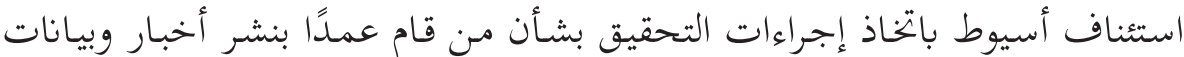

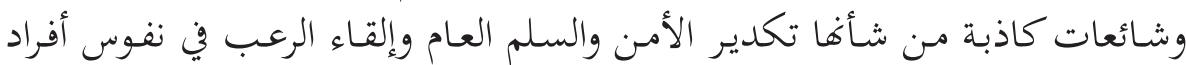

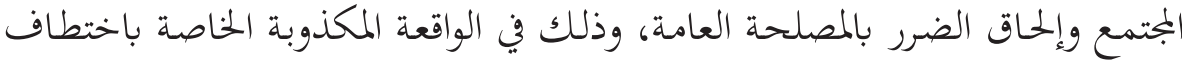

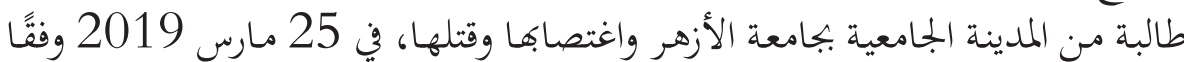

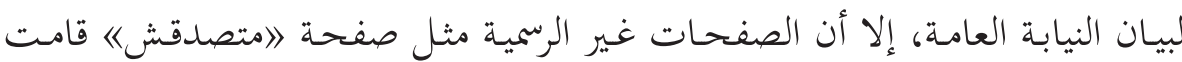

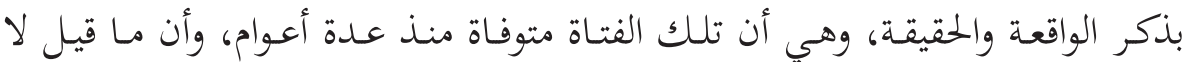


يمت للحقيقة بصلة.

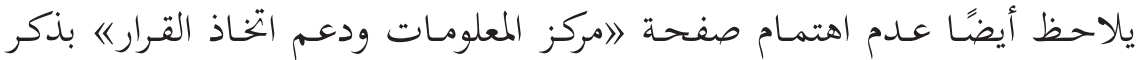

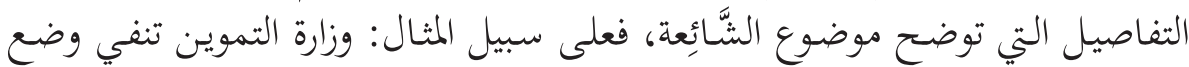

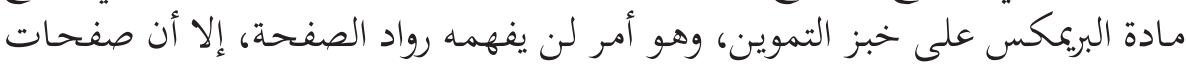

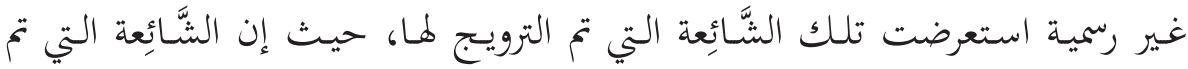

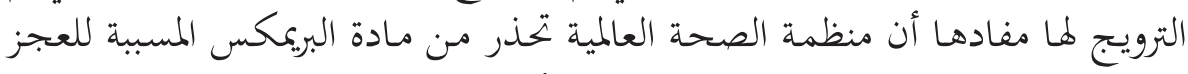

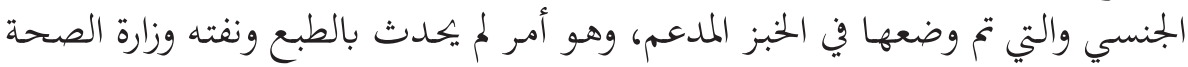

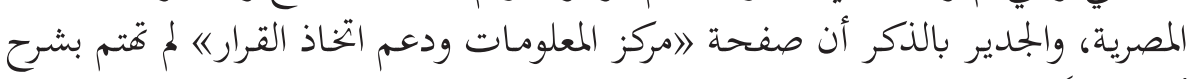
أبعاد الشََّائعة.

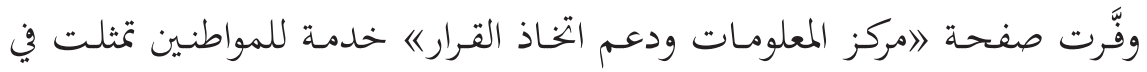

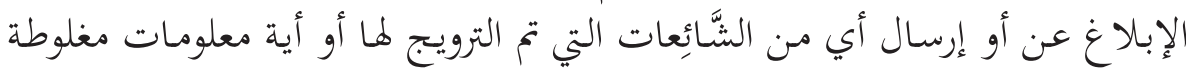

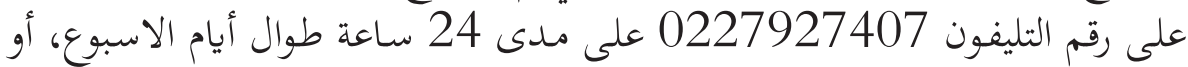

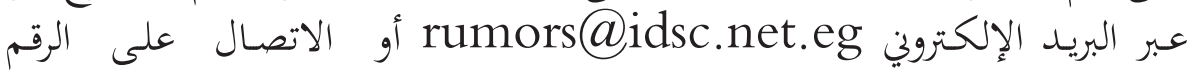
الخناص ببوابة الشكاوى الحكومية 16528.

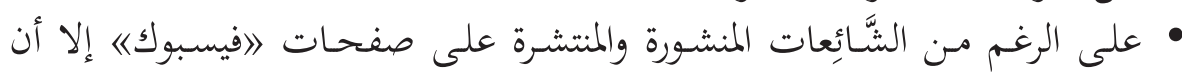

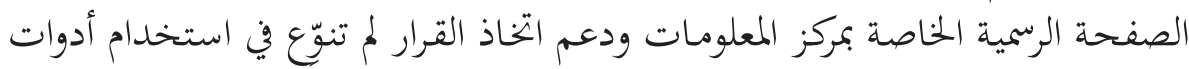

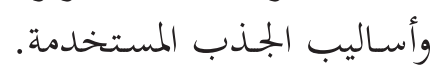

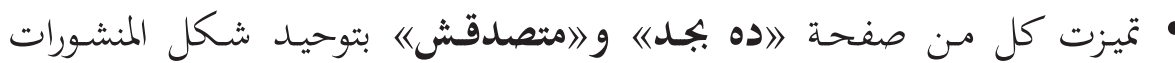

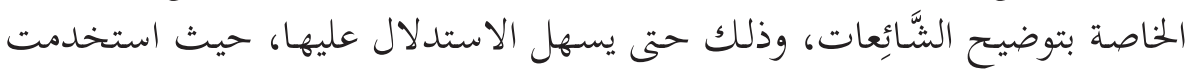

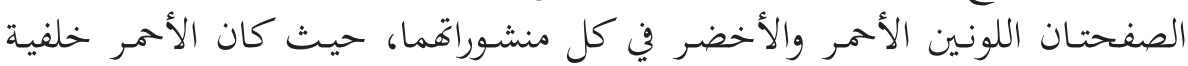

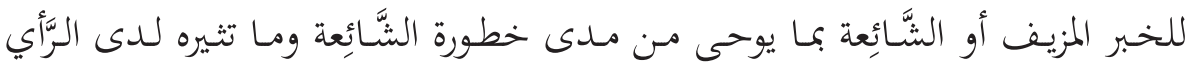

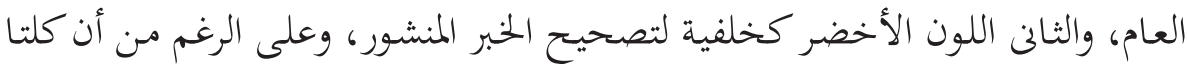

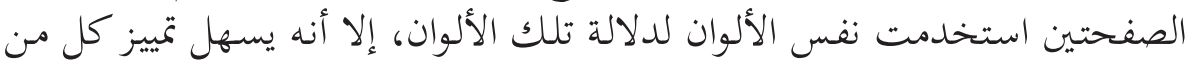
الصفحتين للدى متابعيهما.

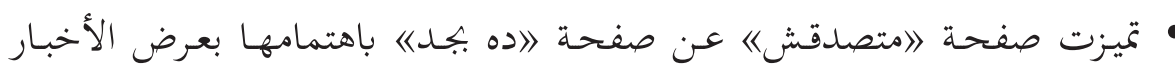

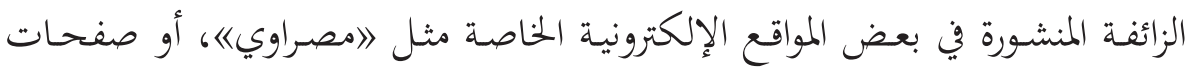

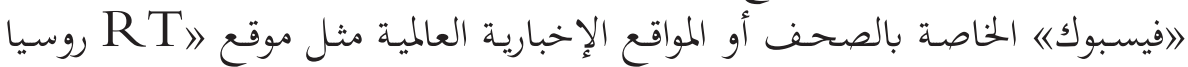

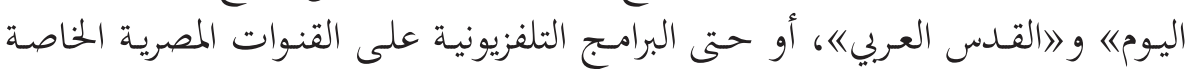

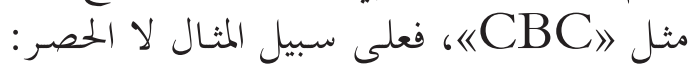

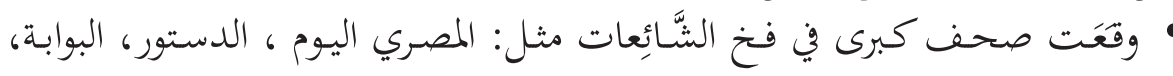




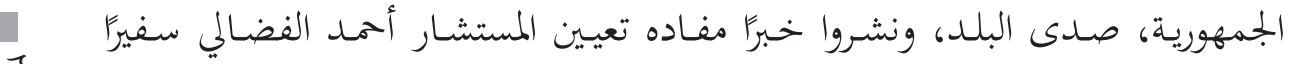

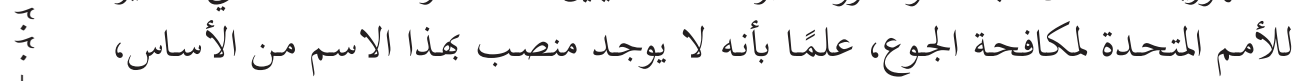

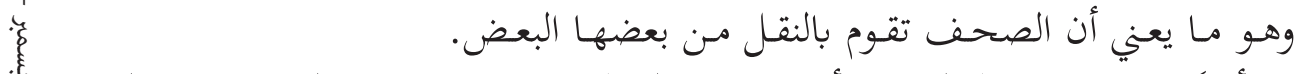

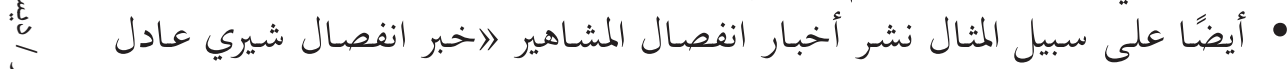

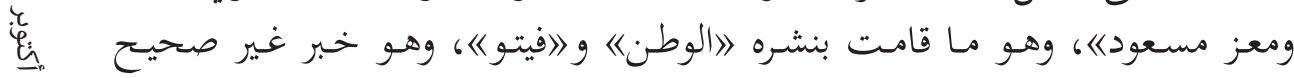

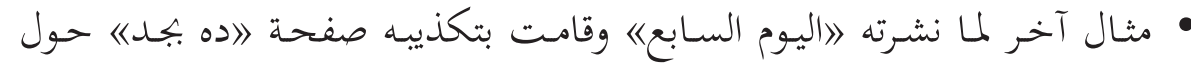

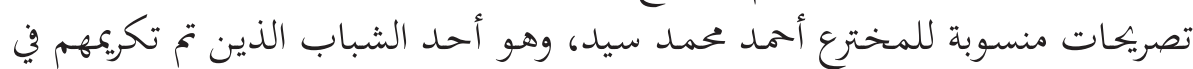

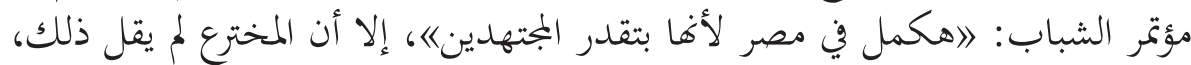

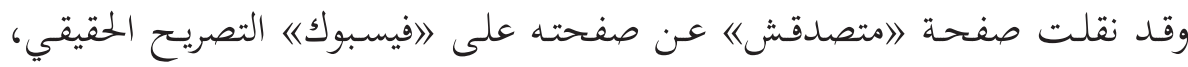

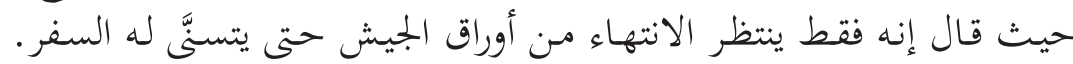

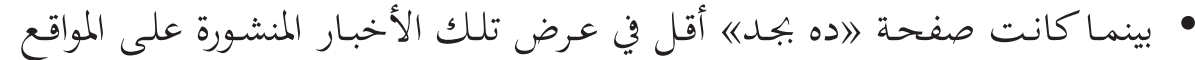

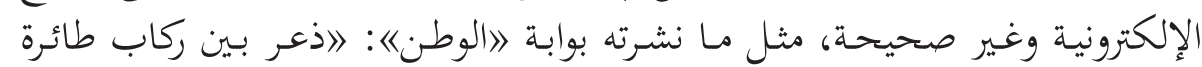

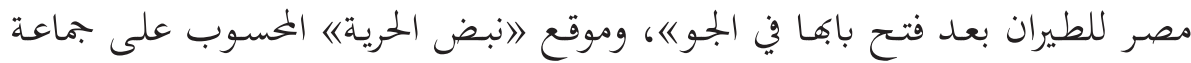

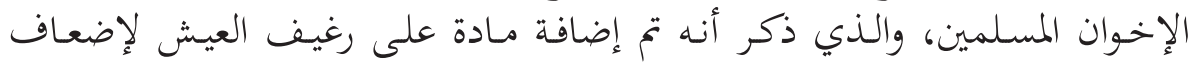

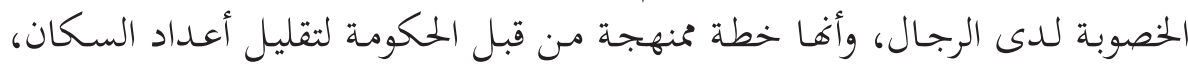

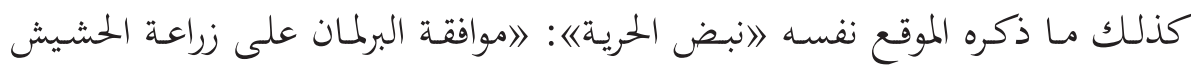

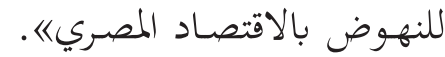

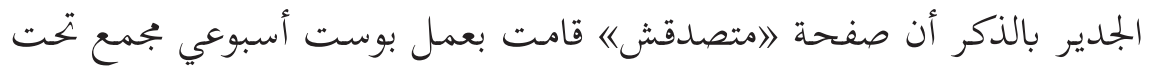

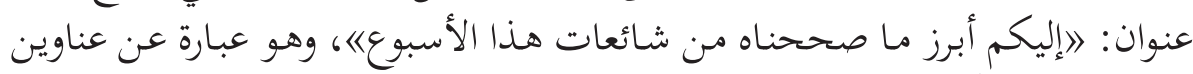

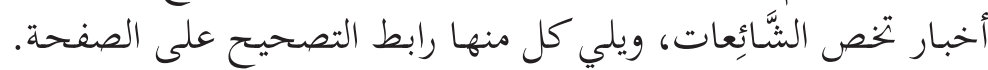

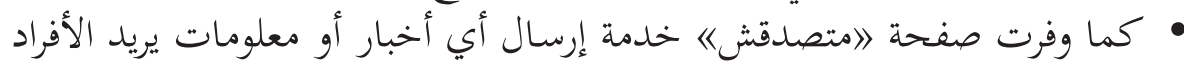

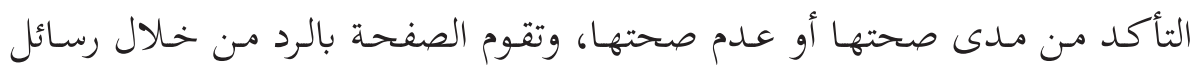

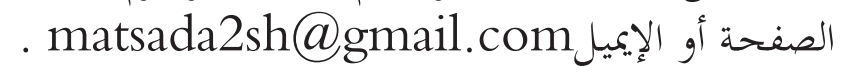

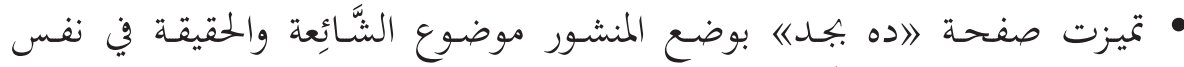

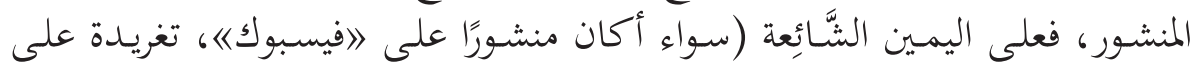

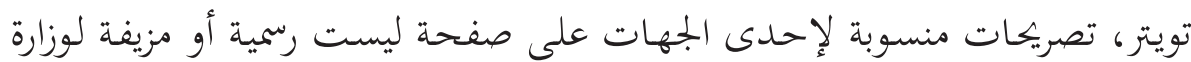

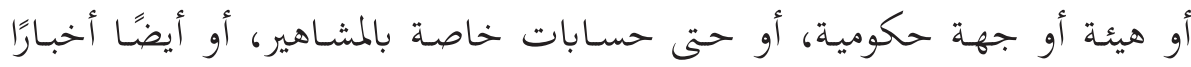

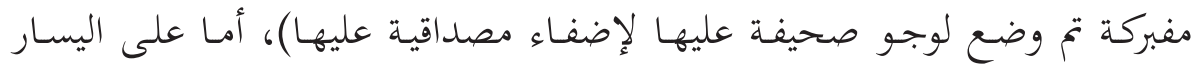
فكان تصحيَح الشَّائعة. 
بمكن القول إن هنـاك نمطية للصورة التي تظهر بهـا صفحات مقاومـة الشَّائِعات

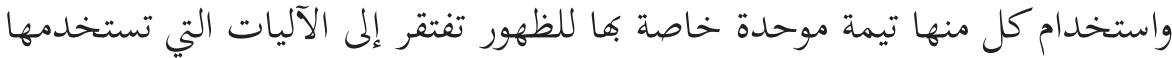

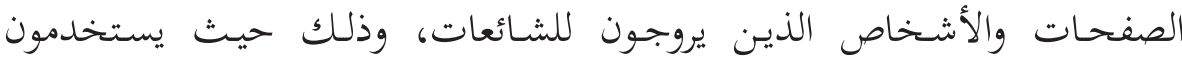

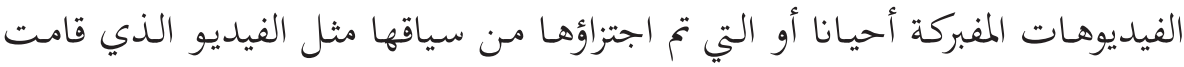

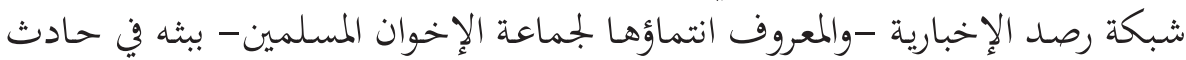

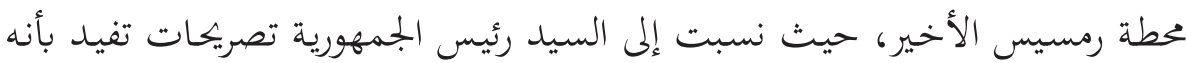

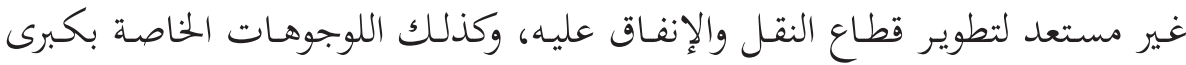

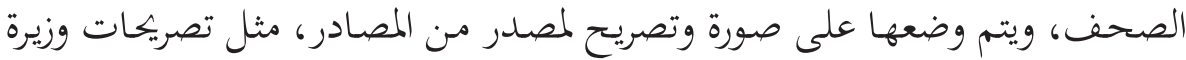

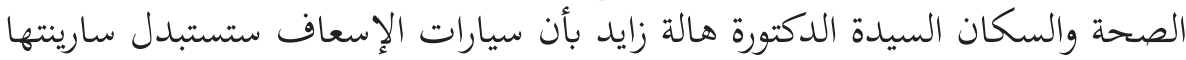

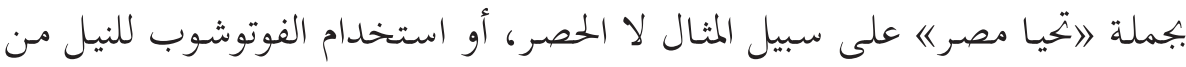

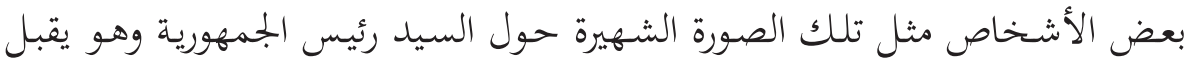

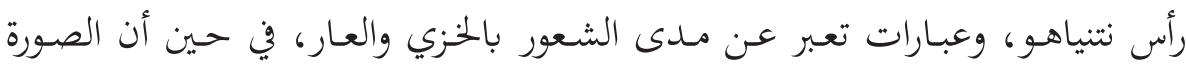

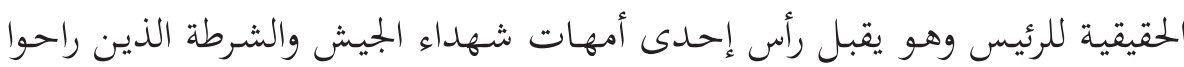

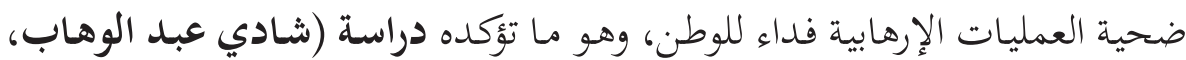

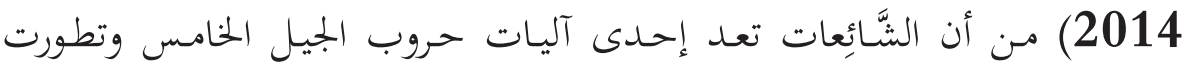

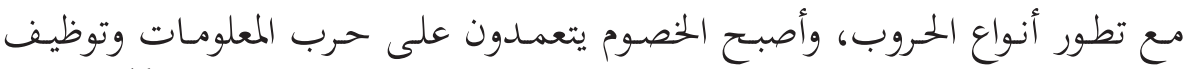

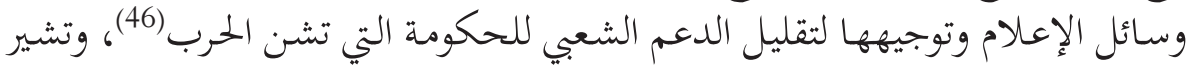

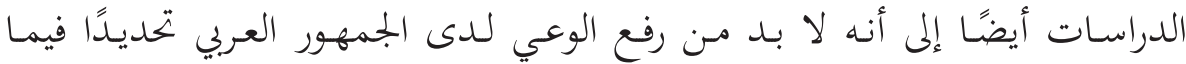

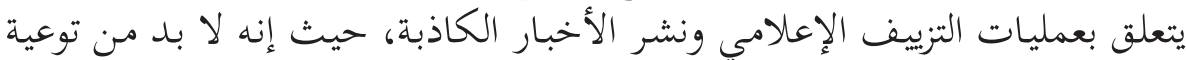

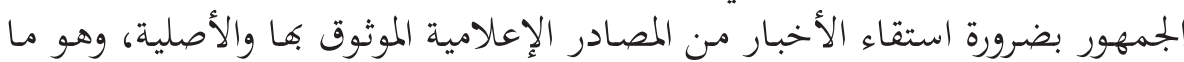

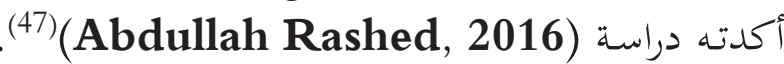

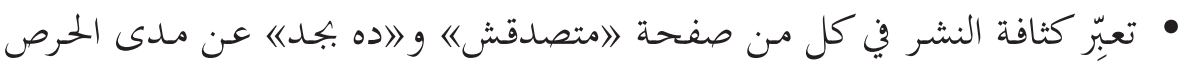

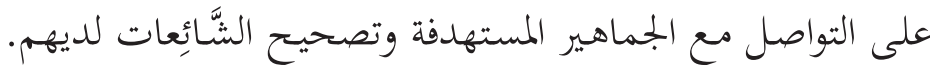

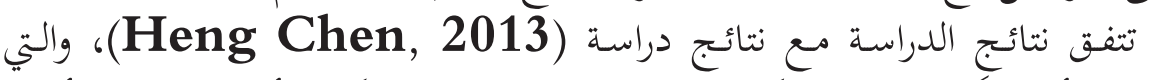

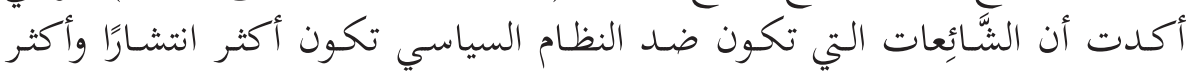

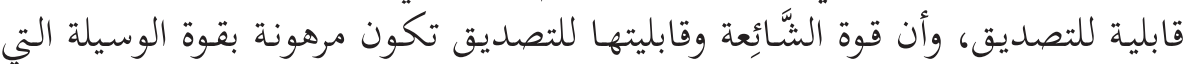

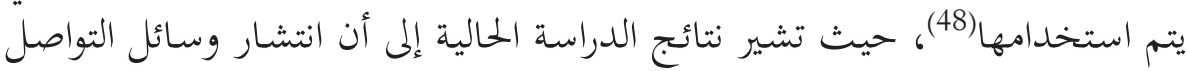

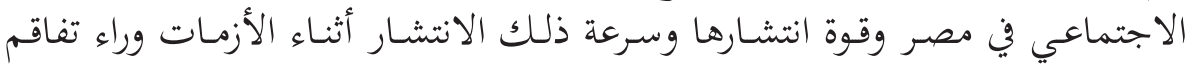

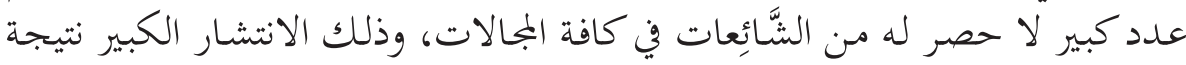

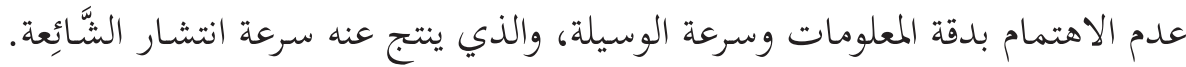




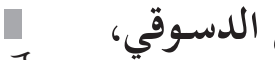

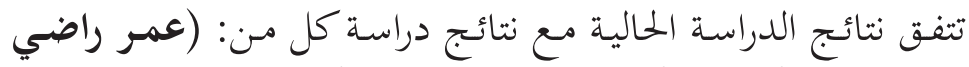
2013)، والتي أكدات أن غيـاب الشفافية وتأخر التصريهات الرسميـة وراء تفاقم

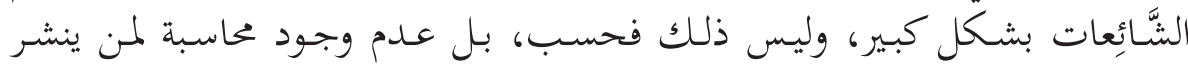

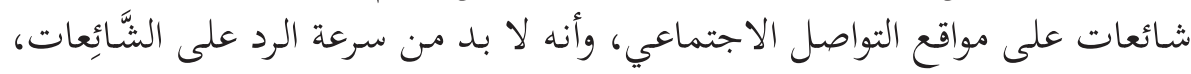

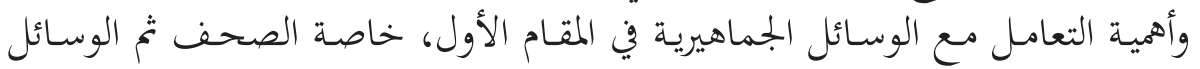

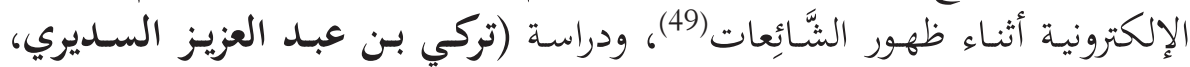

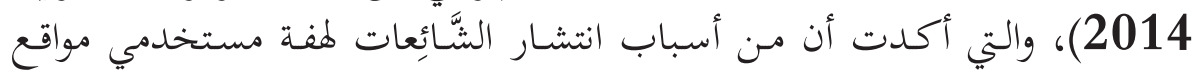
التواصل الاجتماعي في معرفة أي خبر مثير، وسهولة تأثر بعض مستخدمي الشبي الثبكات

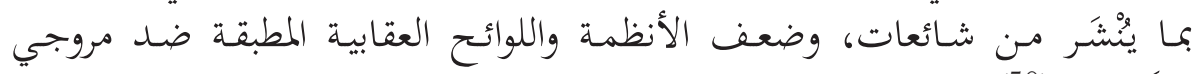
الشَّائعات (50)

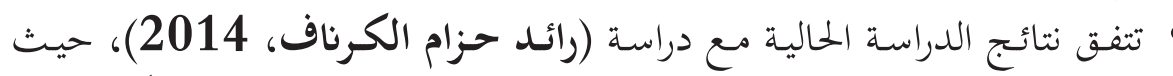
أكدات الدراسة أن المجتمع المتمتع بالشفافية والصراحة يستطيع مواجهة الشَّائعة دون

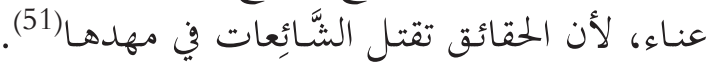
• ويمكن أن نستنتج محا سبق أن حروب الجيل اللنامس تركز على الجمتمع، وهو ما

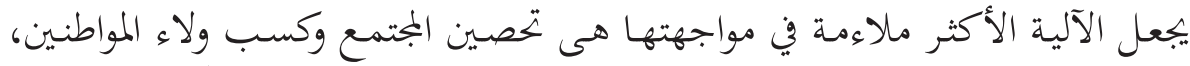

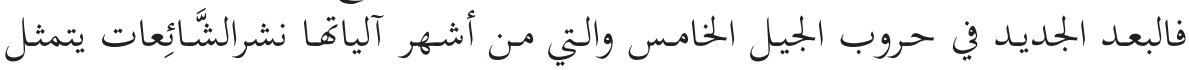

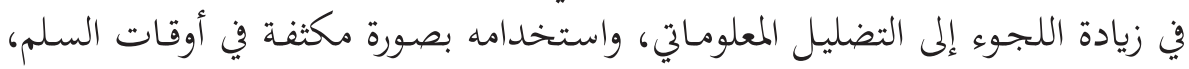
وعدم اقتصار حروب المعلومات على فترات المواجهات العسكرية بين الدول الأمر الى أكدته دراسة (شادى عبد الوهـابـ، 2017). (52)

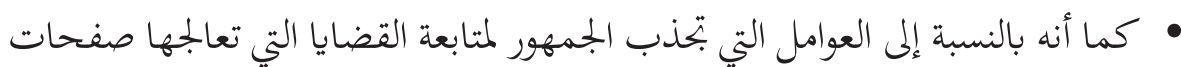

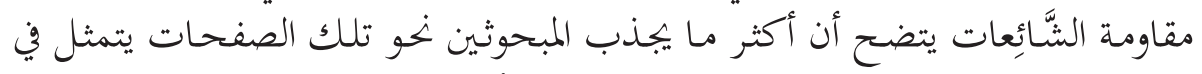

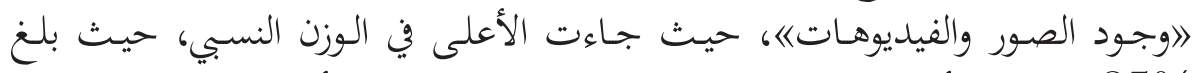

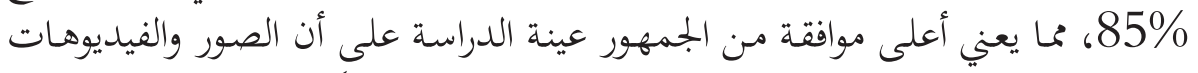

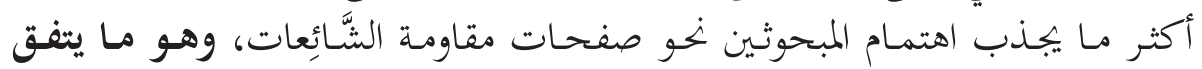

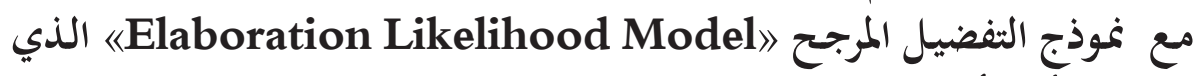
يشير إلى أن الأفراد يميلون من خحلال المل المسار المركزي في عقولهم إلى الاهتمام بجودة

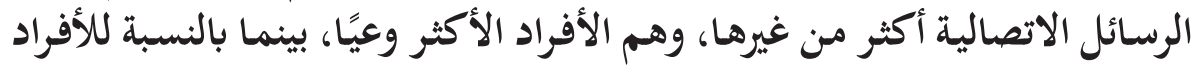

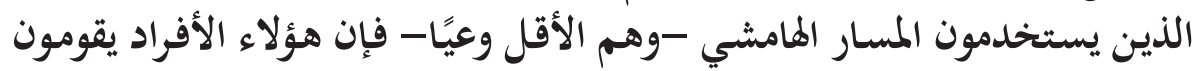
بفحص الرسائل الاتصالية، ولكن بشكل ليس كبيرا، ويركزون على مفاتيح معينة

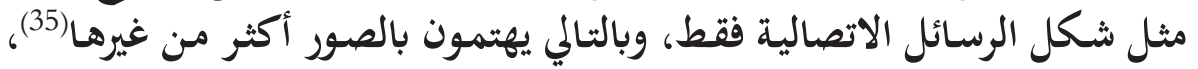


وهو ما يتضح أيضًا من النتائج، والتي أكدت أن 》الأرقام والإحصاءاتهات جاءت الأقل

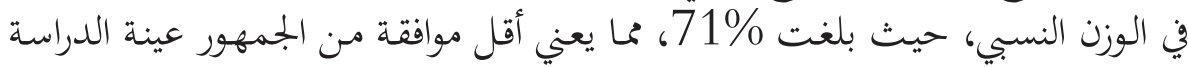

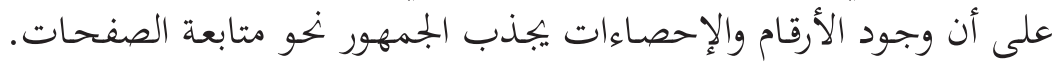

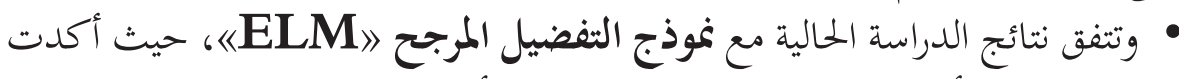

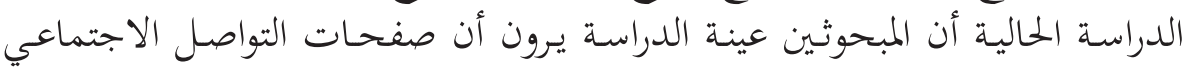

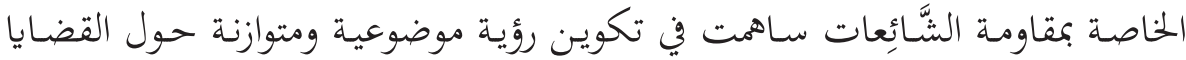

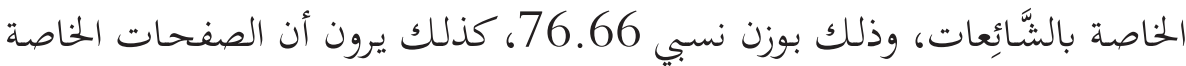

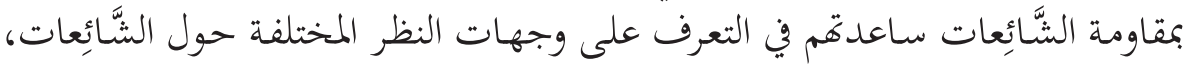

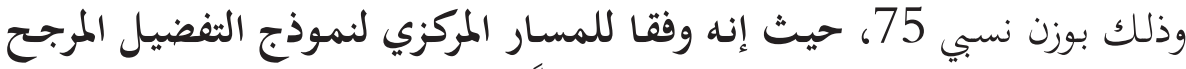

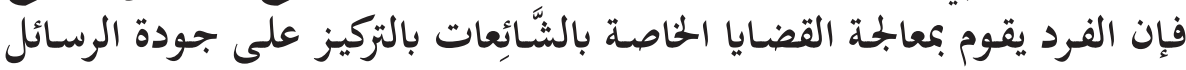

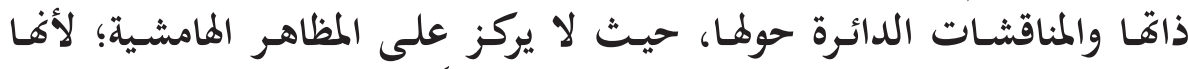

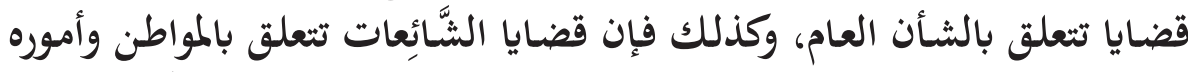

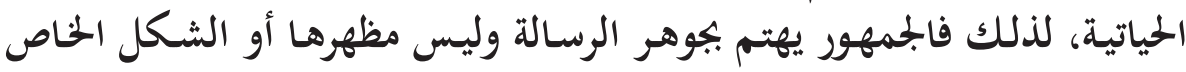

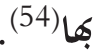

كذلك تتفق نتائج الدراسة الحالية مع نموذج التفضيل المرجح

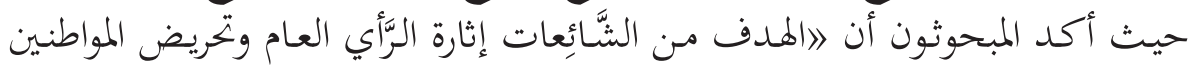

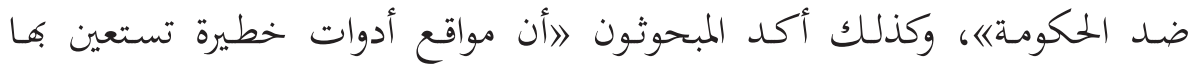

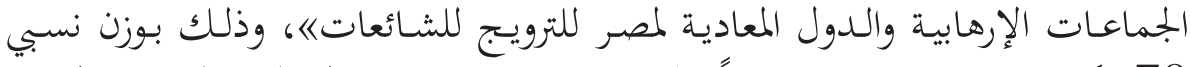

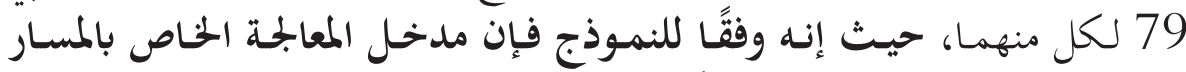

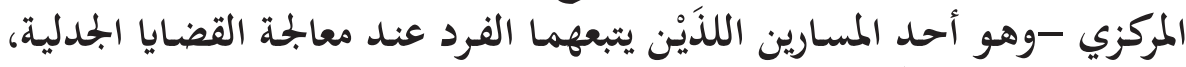

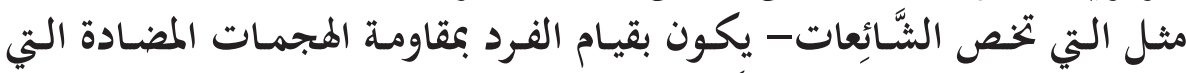

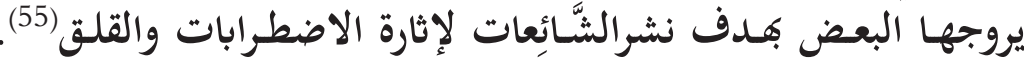


• ضرورة إنشاء صفحة مستقلة عن صفحة 》اتوكز المعلومات ودعم اتخاذ القراريات

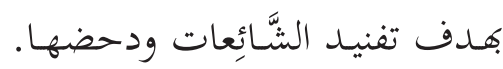

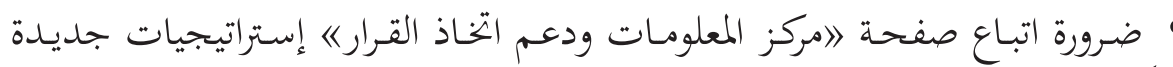

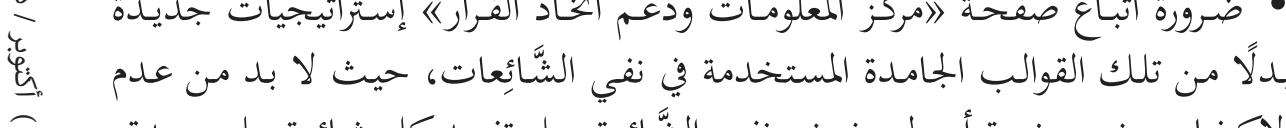

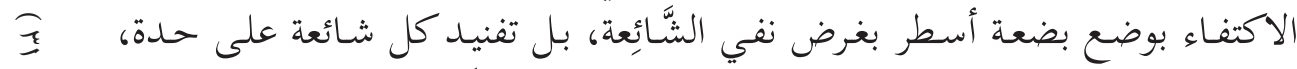

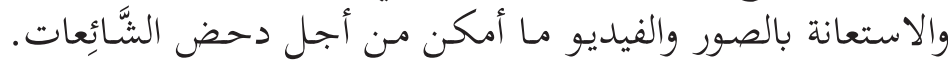

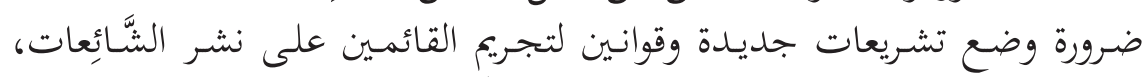

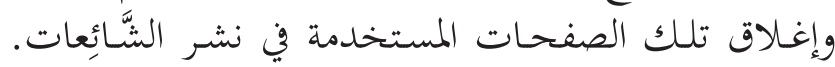

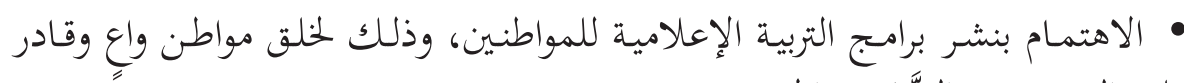

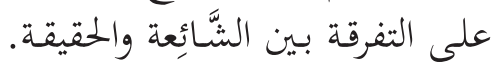

(.).

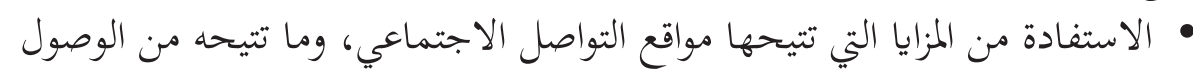

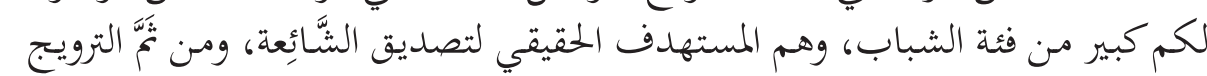
لما والتوسع في صفحات دحض الشَّائعات.

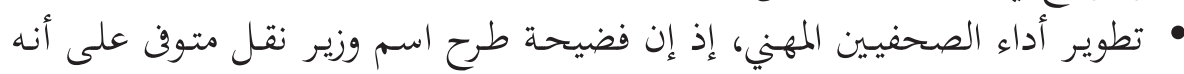

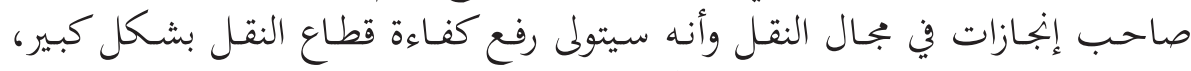

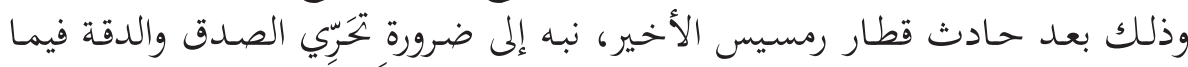

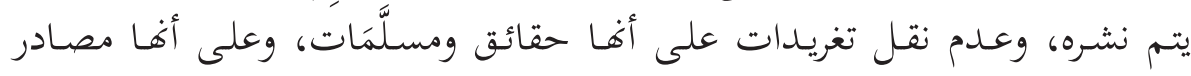

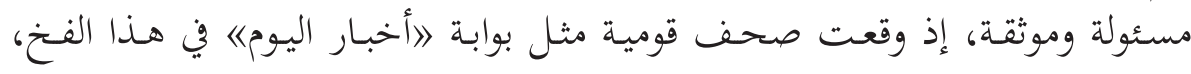

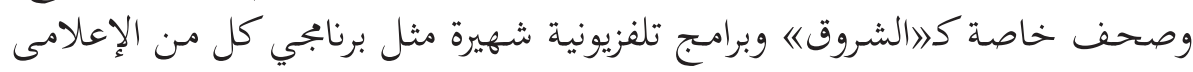

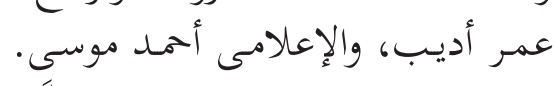

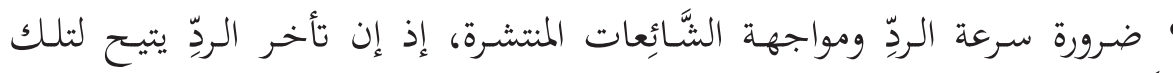

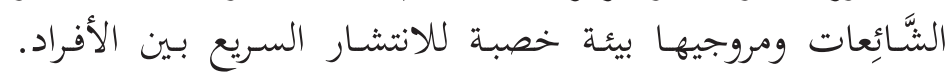

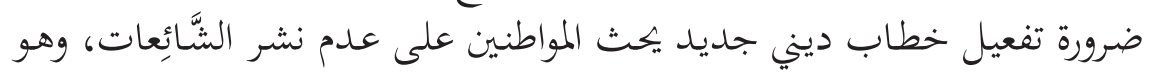

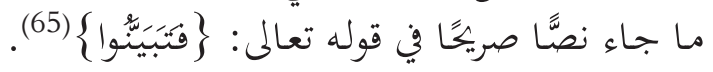

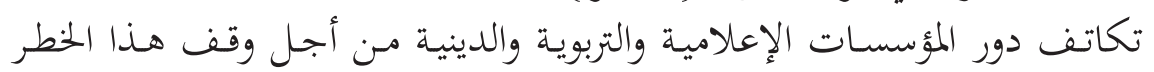

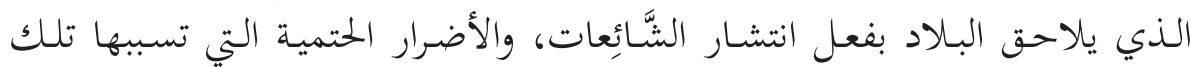

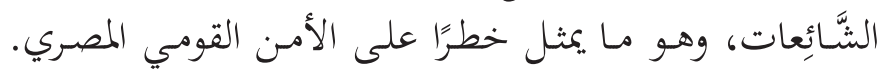




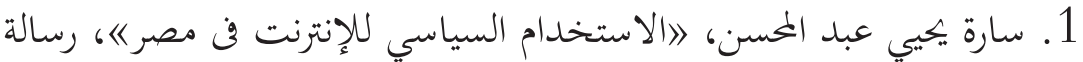

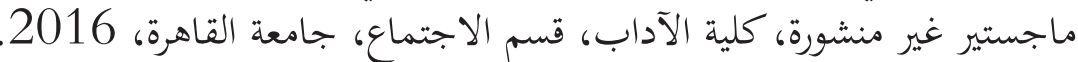

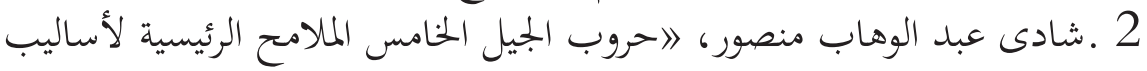

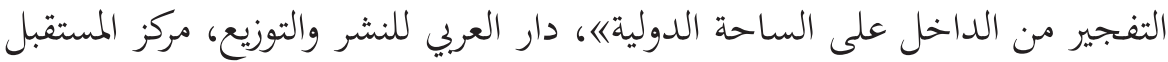

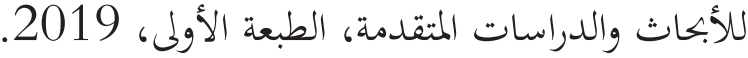

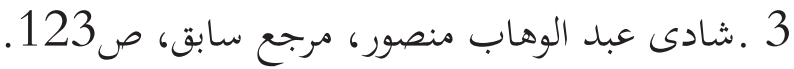

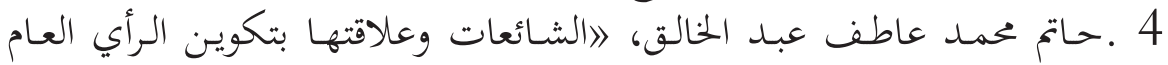

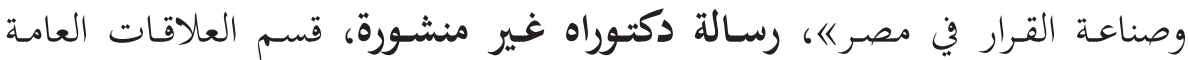
والإعلان، كلية الإعلام، جامعة العادة القاهرة، 2018.

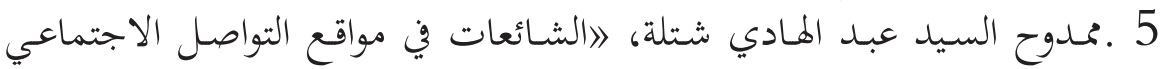

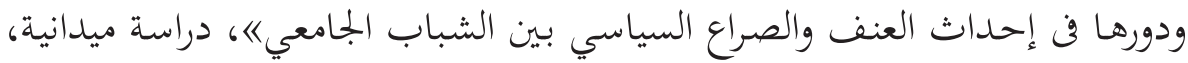
ججلة بحوث العلاقات العامة، الشرق الأوسط، السنة (5) ، العدد العداع (16)، يوليو

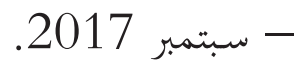

6. Chen Heng, K. Lu Yangm Suen Wing,"Power of whispers: A Theory of rumor", Communication and Revolution, International Economic Review, 2016.

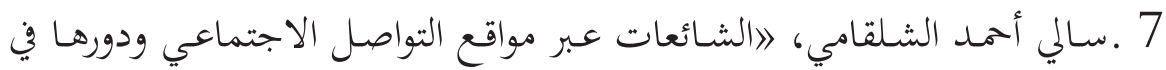

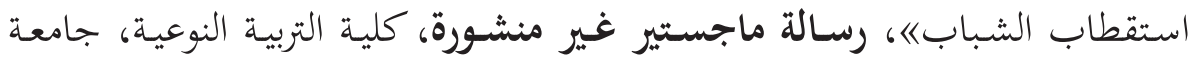
طنطا.

8 لوجين محمد متولي، الالشائعات في مواقع التواصل الاجتماعي وعلاقتها

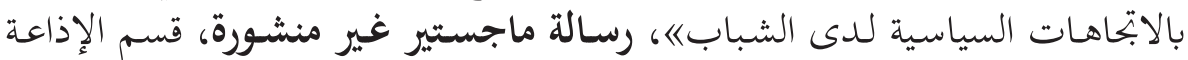

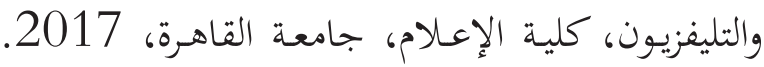

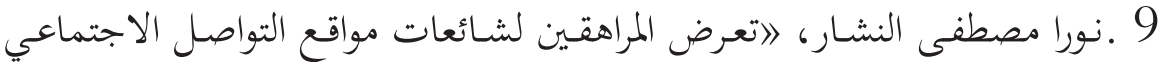

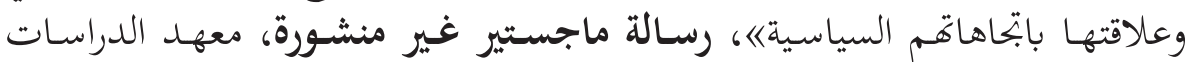

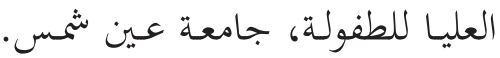
10 أيمن منصور وافي، الاتحاهات الشباب الفلسطيني نحو الشائعات أثناء العدوان

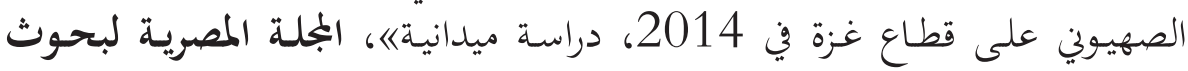
الإعلام، العدد (55)، أبريل - يونيو 2016. 


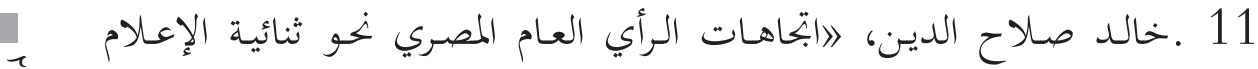

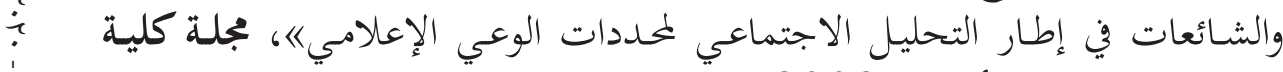

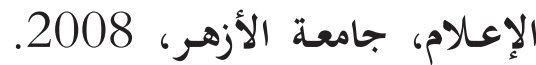

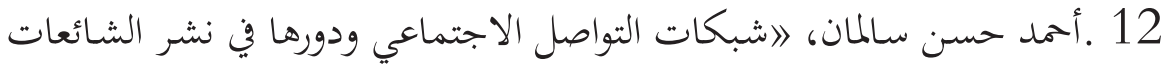

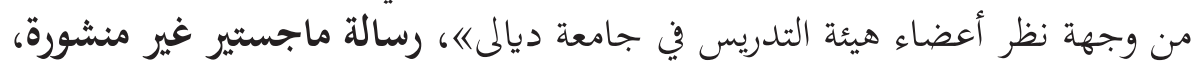

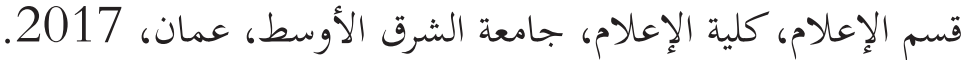

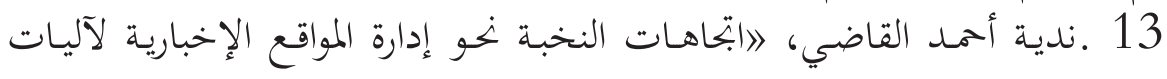

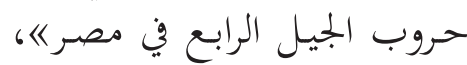
14. Qin Zhiwei, Cai Jian Wagchen H.Z, "How rumors spread and stop over social media: A multi Layered communication model and empirical analysis", vol. (36), artical, 2015.

15. Fang Lui, Andrew Burton Jones, "Rumors on social media disasters: Extending transmission to retransmission".

16 ـرائد حزام الكرناف، الصور إستراتيجي لمكافحة الشائعات في مواقع التواصل

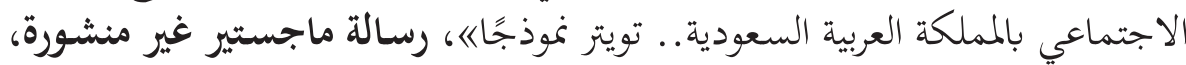

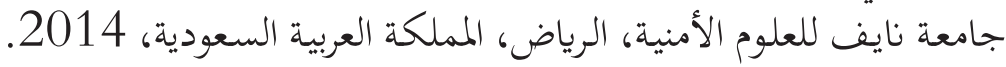

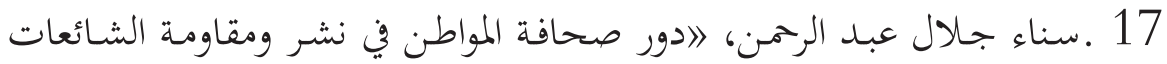

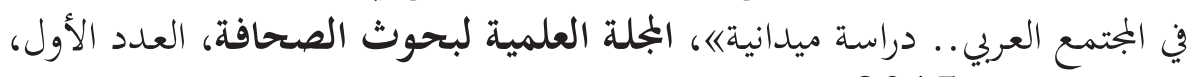

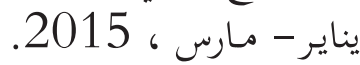

18. Shapiro, Michael A. \& Chock, T. Makana, "Media dependency and perceived reality of fiction and news", USA: Rouledge- Taylor and Francis Group, Journal of Broadcasting \& Electronic Media, vol. (48), no.(4), 2004, pp. 675-695.

19. Merskin, Debra L \& Huberlie, Mara, "Companionship in The Classifieds: The adoption of personal advertisements bydaily newspapers", Atlanta, Georgia: the Annual Meeting of the Association for Edu- 
cation in Journalism and Mass Communication (AEJMC) 77th, August 10-13, 1994, pp. 125-130. 20 محمد أحمد فضل الحديدي، التقييم الرأي العام لأداء سياسة مصر الخارجية

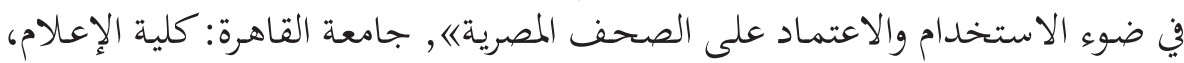

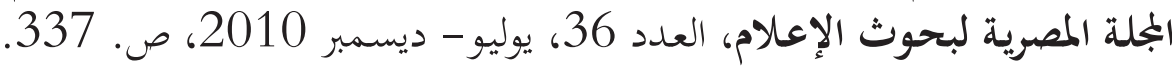

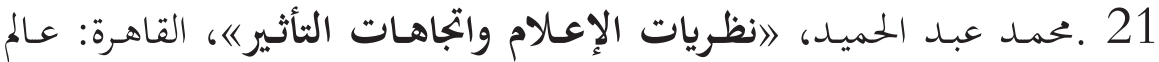

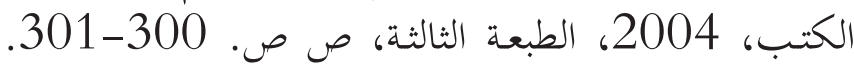

22. Patwardhan Padmini and Yang Jin,'Internet Dependency Relation And Online Consumer behavior:A media system dependency theory prespective on why people shop, chat and read news online",Journal Of Interactive Advertising ,Vol.(3) ,No.(2),2003, pp 57-69

23. Einwiller A. Sabine, Carroll E. Craig, Korn Kati, "Under what conditions do the news media influence corporate reputation? The role of media dependency and need for orientation ", Corporate reputation review, Macmillan publishers LTD, vol. (12), no.(4), 2014, P.P.299-315.

24. Narasim hamurthy N."New media and new culture:The Dependency of Indian Online Community", IOSR Journal of Humanities and social communities, Vol. (9), Issue 10, October 2014.

25 ـ ياسمين صلاح عبد الرممن، الاستخدام الشباب لمواقع الشبكات الاجتماءعاعية

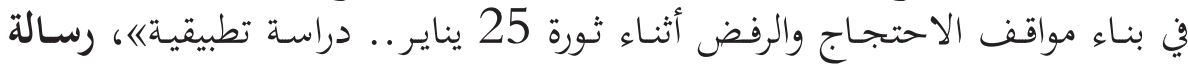

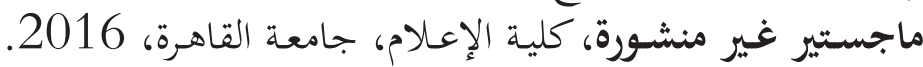

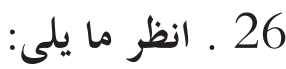

- Ognyanova Katherine , J. Sandra Rokeach Ball, "Political Efficiacy of the internet: A media system dependency approach", Communication and technolo- 
gies annual. Studies in Media \& Communication, $\dot{i}$ Vol. (9), Jan. 2015, P.P. 3-27.

- Riffe Daniel, "Media System Dependency Theory and using the internet for In-Depth Specialized information' WJMCR, Jan 2008.

玉 27. Loveless Matthew, "Media Dependency: Mass media as source of information in the democratizing countries of central and Eastern Euorope" Democratization, London, 2008. 28 . بحمد عبد الحميد، انظريات الإعلام وابحاهات التأثيره، القاهرة، عالم

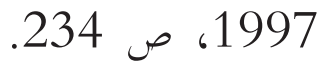

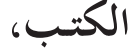

29. Sian Lee Chei, "Exploring emotional expressions on you tube through the lens of media system dependency theory", New Media and Society, vol.(14), no.(3), 2012.

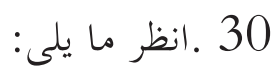

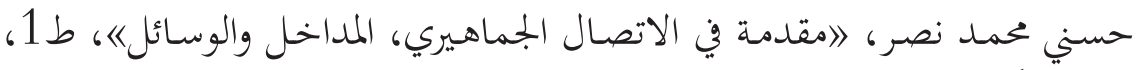

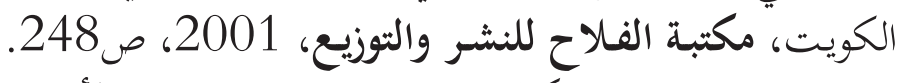

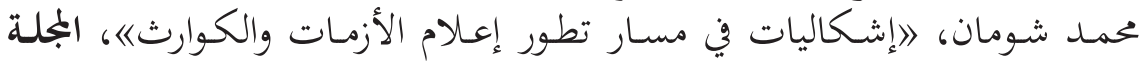

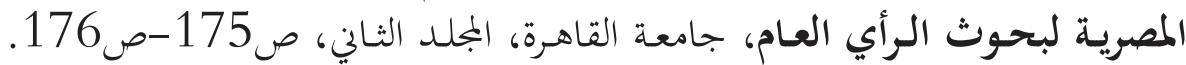
صميرفت الطرابيشي، عبد العزيز السيد، انظريات الاتصاله، دار النهضة العربية،

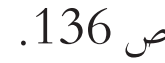

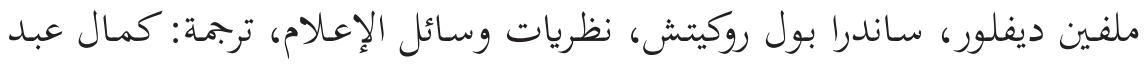

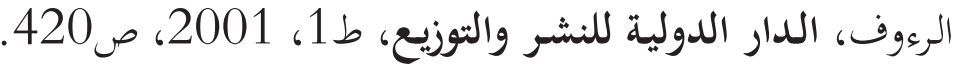

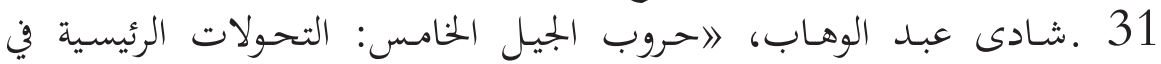

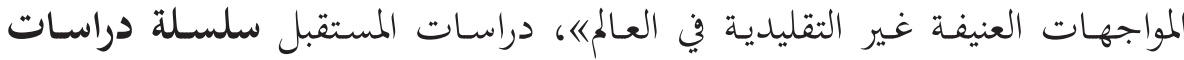
تصددر عن المستقبل للأبحاث والدراسات المتقدمة، أبو ظبي، الإمارات العربية دلماتية

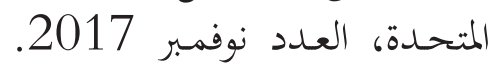
32 ـشادى عبد الوهاب منصور، مرجع سابق، ص169. 


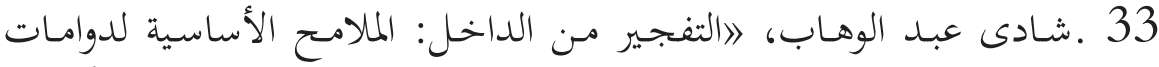

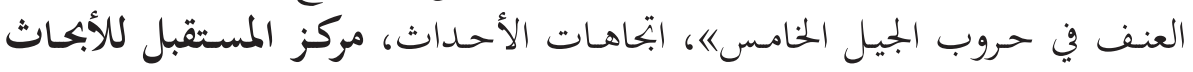

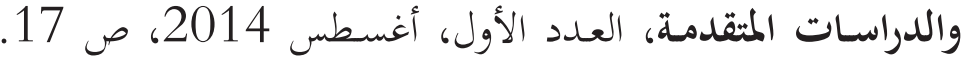

34. Rashad Abdullah, "the impact of media disinformation on public opinion", International Journal of public opinion, Vol.(7),no.(6), June 2016, P.P.131132.

$$
35 \text { شادي عبد الوهب منصور، مرجع سابق، ص121. }
$$

36. Rashad Abdullah, "the impact of media disinformation on public opinion", International Journal on public opinion", Ibid, p.133.

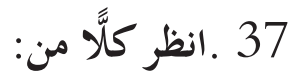

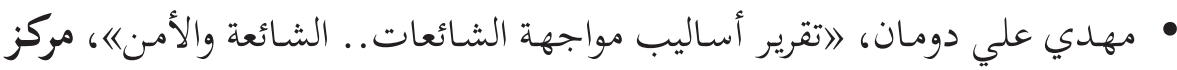



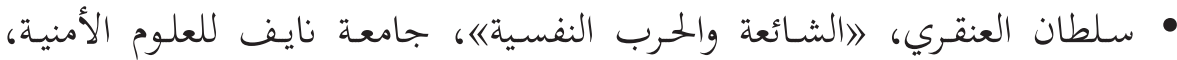

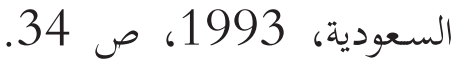
38 ـمحمد عثمان الخشت، 》الشائعات وكلام الناس《، مكتبة ابن سينا، 1996،

$$
\text { } 39 \text {. خالد صلاح الدين، مرجع سابق، ص5 . } 40
$$

- Fang Lui, Andrew Burton Jones, "Rumors on social media disasters: Extending transmission to retransmission", Opcit.

- Richard E. Petty, Pablo Brinol, "Handbookof Theories of Social Physchology", Chapter 2 :"The Elaboration Likelihood Model", Volume 1.

- Hamilton A. Mark, Hunter E. John, Boster J. Franklin," The Elaboration Likelihood model as a theory of attitude formation: A Mathematical analysis", Com- 
munication Theory, Vol.(3), no.(1), www.onlinelibrary. Wiley.com, P.50.

41. www.Changingminds.org,Elaboration LikelihoodMethods.

42 ـ أ.د. هبة شاهين، أستاذ ورئيس قسم علوم الاتصال والإعلام، كلية الآداب،

جامعة عين شمس. أ.د. محمد سعد إبراهيم، عميد أكاديمية الشروق.

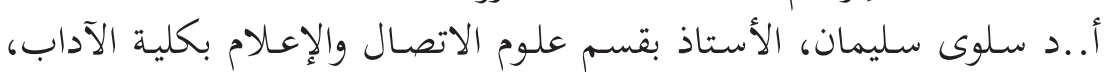

جامعة عـن شمس.

د. شيرين عمر، المـدرس بقسم علم الاتصال والإعلام بكلية الآداب، جامعة

43. أ. نسمة محمد، المدرس المساعد بقسم علوم الاتصال والإعلام، بكلية الآداب

بجامعة عين شمس.

44 ـ شادي عبد الوهاب، الحروب الجيل الخامس: التحولات الرئيسية في

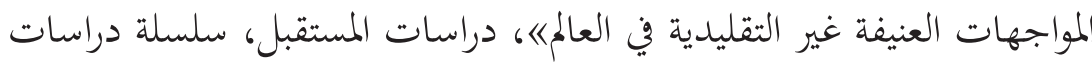

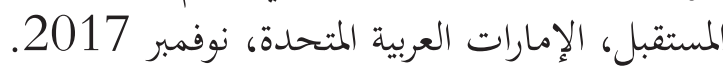

45. Rashad Abdullah, "the impact of media disinformation on public opinion", International Journal on public opinion, opcit.

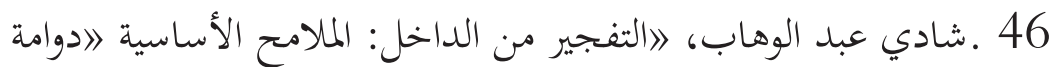

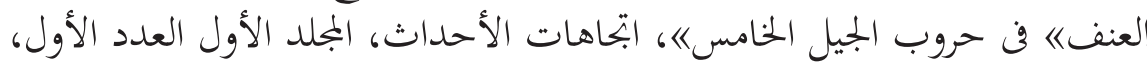

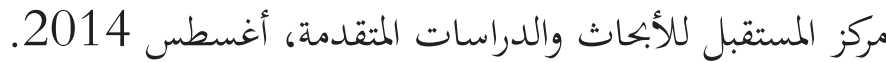

47. Rashad Abdullah, "the impact of media disinformation on public opinion", International Journal on public opinion, opcit.

48. Heng Chen, "The Power of whispers: A Theory of Rumor", Communication and Revolution, Hong Kong, Uni. Of Science and Technology.

49 ـعمرو راضي الدسوقي، ادور إدارة العلاقات العامة في مواجهة الشائعات:

دراسة تحليلية وميدانية لعينة من القطاعات المصريةها، رسالة ماجستير غير منشورة، 


$$
\text { كلية الآداب، قسم الإعلام، جامعة حلوان، } 2013 .
$$

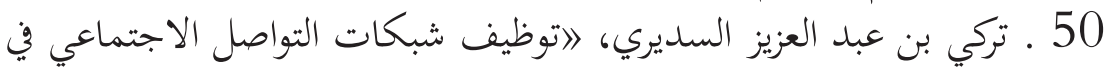

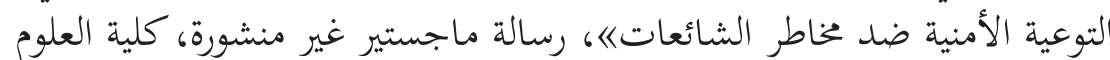

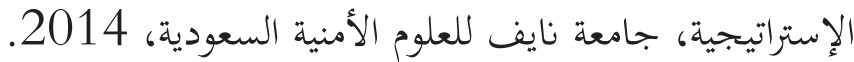

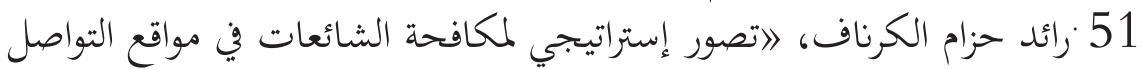

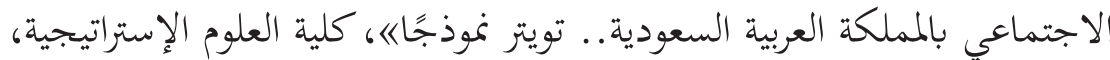

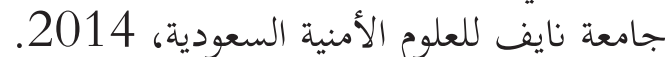

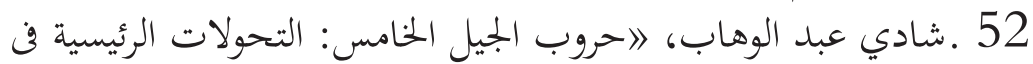

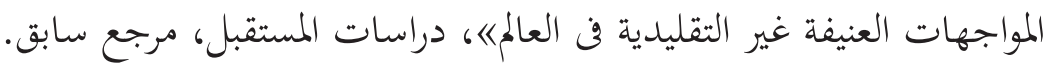
53

- Fang Lui, Andrew Burton Jones, "Rumors on social media disasters: Extending transmission to retransmission", Opcit.

- Richard E. Petty, Pablo Brinol, "Handbookof Theories of Social Physchology", Chapter 2 :"The Elaboration Likelihood Model", Volume 1.

- Hamilton A. Mark, Hunter E. John, Boster J. Franklin, "The Elaboration Likelihood model as a theory of attitude formation: A Mathematical analysis", Communication Theory, Vol.(3), no.(1), www.onlinelibrary. Wiley.com, P. 50.

() www. Changingminds.org,Elaboration LikelihoodMethods.

54. Ibid.

55. Ibid.

$$
56 \text { ـ سورة الحجرات، الآية: } 6 .
$$




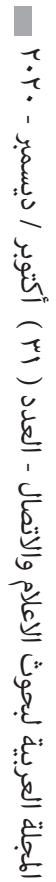

449 المجلة العربية لبحوث الاعلام والاتصال 